IMISCOE Research Series

Jean:Michel Laflétur

Mikolajstane Ek Editors

ZurichO BLIECH

CE GS: Milan

STE CANDSN

$\underbrace{e}_{0}$ 


\section{IMISCOE Research Series}


This series is the official book series of IMISCOE, the largest network of excellence on migration and diversity in the world. It comprises publications which present empirical and theoretical research on different aspects of international migration. The authors are all specialists, and the publications a rich source of information for researchers and others involved in international migration studies.

The series is published under the editorial supervision of the IMISCOE Editorial Committee which includes leading scholars from all over Europe. The series, which contains more than eighty titles already, is internationally peer reviewed which ensures that the book published in this series continue to present excellent academic standards and scholarly quality. Most of the books are available open access.

For information on how to submit a book proposal, please visit: http://www. imiscoe.org/publications/how-to-submit-a-book-proposal.

More information about this series at http://www.springer.com/series/13502 
Jean-Michel Lafleur - Mikolaj Stanek Editors

\section{South-North Migration of EU Citizens in Times of Crisis}

黛 Springer Open 


\author{
Editors \\ Jean-Michel Lafleur \\ Centre for Ethnic and Migration \\ Studies (CEDEM) \\ Université de Liège \\ Liège, Belgium
}

\author{
Mikolaj Stanek \\ Department of Sociology \\ and Communication \\ University of Salamanca \\ Salamanca, Spain
}

ISSN 2364-4087

IMISCOE Research Series

ISBN 978-3-319-39761-0

DOI 10.1007/978-3-319-39763-4
ISSN 2364-4095 (electronic)

ISBN 978-3-319-39763-4 (eBook)

\section{Library of Congress Control Number: 2016954632}

(c) The Editor(s) (if applicable) and The Author(s) 2017. This book is published open access.

Open Access This book is licensed under the terms of the Creative Commons AttributionNonCommercial 2.5 License (http://creativecommons.org/licenses/by-nc/2.5/), which permits any noncommercial use, sharing, adaptation, distribution and reproduction in any medium or format, as long as you give appropriate credit to the original author(s) and the source, provide a link to the Creative Commons license and indicate if changes were made.

The images or other third party material in this book are included in the book's Creative Commons license, unless indicated otherwise in a credit line to the material. If material is not included in the book's Creative Commons license and your intended use is not permitted by statutory regulation or exceeds the permitted use, you will need to obtain permission directly from the copyright holder.

This work is subject to copyright. All commercial rights are reserved by the Publisher, whether the whole or part of the material is concerned, specifically the rights of translation, reprinting, reuse of illustrations, recitation, broadcasting, reproduction on microfilms or in any other physical way, and transmission or information storage and retrieval, electronic adaptation, computer software, or by similar or dissimilar methodology now known or hereafter developed.

The use of general descriptive names, registered names, trademarks, service marks, etc. in this publication does not imply, even in the absence of a specific statement, that such names are exempt from the relevant protective laws and regulations and therefore free for general use.

The publisher, the authors and the editors are safe to assume that the advice and information in this book are believed to be true and accurate at the date of publication. Neither the publisher nor the authors or the editors give a warranty, express or implied, with respect to the material contained herein or for any errors or omissions that may have been made.

Printed on acid-free paper

This Springer imprint is published by Springer Nature

The registered company is Springer International Publishing AG Switzerland 


\section{Foreword}

The financial and economic crisis has been a challenge for the European integration process, and, in many respects, the study of South-North EU migration in times of crisis reveals as much about contemporary mobilities in the EU as it does on Member States' willingness to build solidarity across borders.

To study this phenomenon, we considered the involvement of scholars and institutions from both Southern and Northern Europe as the only possible option. This edited volume is thus the result of true collective work involving many different actors whom we wish to sincerely thank for their support and dedication throughout this project.

We first wish to thank the IMISCOE Research Network and Universidad Pontificia Comillas in Madrid to have hosted our first workshop on South-North EU migration in August 2014, during which the idea of this book was initially discussed. Second, different Belgian institutions have allowed this idea to be transformed into a fully fledged publication project. We hereby wish to thank the University of Liège, which granted us a special research fund to support this book, as well as its Social Science Faculty (FaSS) and its Centre for Ethnic and Migration Studies (CEDEM). We would also like to thank the Belgian National Fund for Scientific Research (FRS-FNRS), for financing and hosting our second conference in December 2014 at the University of Liège. Third, we'd like to thank warmly Warda Belabas from the IMISCOE editorial board and Bernadette Deelen from Springer for their support and dedication throughout the publication process. Lastly, as the joint editors of this volume were based in Portugal, Spain and Belgium, we can confirm that this book's manuscript has itself been continuously moving between Southern and Northern Europe. However, a few institutions have given us the necessary stability to work comfortably on the manuscript. We would thus also like to thank the Portuguese Foundation for Science and Technology, which financed 
Mikolaj Stanek's postdoctoral fellowship at the time this volume was prepared (SFRH/BDP/84148/2012), the Centre of Social Studies at the University of Coimbra in Portugal, the Spanish National Research Council (CSIC) and the Library of the Belgian Royal Academy.

Liège, Belgium

Salamanca, Spain

March 10, 2016
Jean-Michel Lafleur

Mikolaj Stanek 


\section{Contents}

1 EU Migration and the Economic Crisis: Concepts and Issues

Jean-Michel Lafleur and Mikolaj Stanek

2 From International Migration to Freedom of Movement and Back? Southern Europeans Moving North in the Era of Retrenchment of Freedom of Movement Rights.

Roxana Barbulescu

3 Immobility in Times of Crisis? The Case of Greece Georgia Mavrodi and Michalis Moutselos

4 Emigration from Italy After the Crisis: The Shortcomings of the Brain Drain Narrative

Guido Tintori and Valentina Romei

5 Structural Emigration: The Revival of Portuguese Outflows José Carlos Marques and Pedro Góis

6 Is Spain Becoming a Country of Emigration Again? Data Evidence and Public Responses

Anastasia Bermudez and Elisa Brey

7 Restrictions on Access to Social Protection by New Southern European Migrants in Belgium. Jean-Michel Lafleur and Mikolaj Stanek

8 Southern Europeans in France: Invisible Migrants? Tatiana Eremenko, Nora El Qadim, and Elsa Steichen

9 Gastarbeiter Migration Revisited: Consolidating Germany's Position as an Immigration Country

Amanda Klekowski von Koppenfels and Jutta Höhne 
10 UK: Large-Scale European Migration and the Challenge to EU Free Movement.

Alessio D'Angelo and Eleonore Kofman

11 South-North Labour Migration Within the Crisis-Affected European Union: New Patterns, New Contexts and New Challenges

Jean-Michel Lafleur, Mikolaj Stanek, and Alberto Veira

12 Lessons from the South-North Migration of EU

Citizens in Times of Crisis

Jean-Michel Lafleur and Mikolaj Stanek 


\section{Contributors}

Roxana Barbulescu ESRC Centre for Population Change and Department of Sociology, Social Policy and Criminology, University of Southampton and College of Europe (Natolin Campus), Warsaw, Poland

Anastasia Bermudez Department of Social Anthropology, Universidad de Sevilla, Sevilla, Spain

CEDEM, Université de Liège, Liège, Belgium

Elisa Brey CEDEM, Université de Liège, Liège, Belgium

GEMI, Universidad Complutense de Madrid, Madrid, Spain

Alessio D'Angelo Social Policy Research Centre, Middlesex University, London, UK

Nora El Qadim CRESPPA-LabTop, Université Paris 8, Paris, France

Tatiana Eremenko Institut National d'Études Démographiques (INED), Paris, France

Pedro Góis Faculty of Economics, University of Coimbra and Centre for Social Studies, Coimbra, Portugal

Jutta Höhne Institute of Economic and Social Research (WSI), Düsseldorf, Germany

Eleonore Kofman Social Policy Research Centre, Middlesex University, London, UK

Amanda Klekowski von Koppenfels Brussels School of International Studies, University of Kent, Brussels, Belgium

Jean-Michel Lafleur FRS-FRNS, Centre for Ethnic and Migration Studies (CEDEM), University of Liège, Liège, Belgium 
José Carlos Marques Polytechnic Institute of Leiria and CICS.NOVA (Unit Leiria), Leiria, Portugal

Georgia Mavrodi European University Institute, Florence, Italy

Michalis Moutselos Princeton University, Princeton, NJ, USA

Valentina Romei Statistical journalist at the Financial Times, London, UK

Mikolaj Stanek Department of Sociology and Communication, University of Salamanca, Salamanca, Spain

Elsa Steichen Université Paris 1 Panthéon-Sorbonne, Paris, France

Guido Tintori FIERI International and European Forum on Migration Research, Turin, Italy

Alberto Veira Department of Social Analysis, Carlos III University of Madrid, Madrid, Spain 


\section{List of Abbreviations}

AAH Allocation aux adultes handicapés AIRE Anagrafe degli Italiani Residenti all'Estero

ALG Arbeitslosengeld

APE-MPE Athens Press Bureau

API

Allocation de parent isolé

APS

Annual Population Survey

BAMF

$\mathrm{BBC}$

Bundesamt für Migration und Flüchtlinge

BMAS

British Broadcasting Corporation

BMBF

Bundesministerium für Arbeit und Soziales

BMI

Bundesministerium für Bildung und Forschung

BREXIT

Bundesministerium des Innern

BVA

United Kingdom's exit of the EU

CEDEM

Bundesverwaltungsamt CBS Centraal Bureau voor de Statistiek

CJEU

Centre d'Etudes de l'Ethnicité et des Migration

CNLTI

Court of Justice of the European Union

CNOM

Commission Nationale de Lutte contre le Travail Illégal

CNRS

Conseil National de l'Ordre des Médecins

DAS

Centre National de la Recherche Scientifique

$\mathrm{DG}$

Droit à l'Aide Sociale

DGT

Directorate General

DIRECCTE Direction Régionale des Entreprises, de la Concurrence, de la

Consommation, du Travail et de l'Emploi Consommation, du Travail et de l'Emploi

EC

European Commission

ECB European Central Bank

EEA European Economic Area

EEC European Economic Community

ELSTAT Hellenic Statistical Agency

EMN European Migration Network

EU European Union 


$\begin{array}{ll}\text { EU-2 } & \text { Bulgaria, Romania } \\ \text { EU-8 } & \text { Czech Republic, Estonia, Hungary, Lithuania, Latvia, Poland, } \\ & \text { Slovakia, Slovenia } \\ \text { EU-10 } & \text { Cyprus, Czech Republic, Estonia, Hungary, Lithuania, Latvia, } \\ & \text { Malta, Poland, Slovakia, Slovenia } \\ \text { EU-12 } & \text { Bulgaria, Cyprus, Czech Republic, Estonia, Hungary, Lithuania, } \\ & \text { Latvia, Malta, Poland, Romania, Slovakia, Slovenia } \\ \text { EU-LFS } & \text { European Union Labour Force Survey } \\ \text { EUROSTAT } & \text { European Union statistical office } \\ \text { FaSS } & \text { Faculté de Sciences Sociales de l'Université de Liège } \\ \text { FAZ } & \text { Frankfurter Allgemeine Zeitung } \\ \text { FRS-FNRS } & \text { Fonds National de la Recherche Scientifique } \\ \text { GDP } & \text { Gross Domestic Product } \\ \text { ICT } & \text { Information and Communications Technology } \\ \text { ILO } & \text { International Labour Organization } \\ \text { IMF } & \text { International Monetary Fund } \\ \text { IMI } & \text { Internal Market Information System } \\ \text { INCA-CGIL } & \text { Istituto Nazionale Confederale di Assistenza-Confederazione } \\ & \text { Generale Italiana del Lavoro } \\ \text { INE } & \text { Instituto Nacional de Estatística } \\ \text { INED } & \text { Institut National d'Etudes Démographiques INSEE Institut } \\ & \text { National de la Statistique et des Études Économiques } \\ \text { INSTAT } & \text { Instituti I Statistikes } \\ \text { IOM } & \text { International Organization for Migration } \\ \text { IPPR } & \text { Institute for Public Policy Research } \\ \text { ISCED } & \text { International Standard Classification of Education } \\ \text { ISCO } & \text { International Standard Classification of Occupations } \\ \text { LFS } & \text { Labour Force Survey } \\ \text { MERCOSUR } & \text { Mercado Común del Sur } \\ \text { NAFTA } & \text { North American Free Trade Agreement } \\ \text { NHS } & \text { National Health Service } \\ \text { NINo } & \text { National Insurance Number } \\ \text { N-VA } & \text { Nieuw-Vlaamse Alliantie } \\ \text { OMI } & \text { Office des Migrations Internationales } \\ \text { OECD } & \text { Organisation for Economic Co-operation and Development } \\ \text { ONS } & \text { Office of National Statistics } \\ \text { PIGS } & \text { Portugal, Italy, Greece, Spain } \\ \text { RIS } & \text { Revenu d'Intégration Sociale } \\ \text { RMI } & \text { Revenu Minimal d'Insertion } \\ \text { RN-DGSIE } & \text { Registre National - Direction Générale Statistique et Information } \\ & \text { Économique } \\ \text { RSA } & \text { Revenu de Solidarité Active } \\ \text { SER } & \text { Sociaal-Economische Raad } \\ \text { SGB } & \text { XII Sozialgesetzbuch XII } \\ & \end{array}$


SVR Sachverständigenrat deutscher Stiftungen für Integration und Migration

UCL Université Catholique de Louvain

UK United Kingdom

UKIP United Kingdom Independence Party

ULG Université de Liège

UN United Nations

UNHCR United Nations High Commissioner for Refugees

US United States

VLD Vlaamse Liberalen en Democraten 


\title{
Chapter 1 \\ EU Migration and the Economic Crisis: \\ Concepts and Issues
}

\author{
Jean-Michel Lafleur and Mikolaj Stanek
}

\subsection{Introduction: South-North EU Migration in (Post-)Crisis Europe}

The global financial and economic crisis has been hitting the European Union severely since 2008. Although the economic crisis began in advanced economies and then spread all over the globe, its impact and implications are far from being equally distributed geographically. This is particularly visible within the European Union. While some countries, mainly in the North, have weathered the crisis relatively well and have managed to recover from the initial financial downturn, others, especially in the South, have been suffering from long-term financial instability, high unemployment rates and worsening living conditions among wide segments of the population. In this deteriorating socio-economic environment, EU citizens have developed a wide variety of strategies to respond to the crisis, such as undertaking training in order to adapt to the changing needs of the job market, reducing household expenditure, or taking to the streets to oppose the management of the crisis by their governments (Promberger et al. 2014).

Traditionally, geographic mobility has been considered by social scientists as a key strategy employed by individuals and households in order to cope with economic hardship. Today, there is sufficient evidence showing that many European citizens have responded to the deterioration of their living conditions by moving to other countries or continents. Nonetheless, despite the media interest in this new European migratory phenomenon, in-depth and systematic analysis is still needed.

J.-M. Lafleur $(\bowtie)$

FRS-FRNS, Centre for Ethnic and Migration Studies (CEDEM), University of Liège,

Liège, Belgium

e-mail: jm.lafleur@ulg.ac.be

M. Stanek

Department of Sociology and Communication, University of Salamanca, Salamanca, Spain

e-mail:mstanek@usal.es 
This edited volume focuses on migration as a specific strategy developed by EU citizens to adjust to an adverse socio-economic environment. In particular, we propose to look at the mobility of EU citizens proceeding from the Southern European Member States that have been most affected by the crisis (Greece, Italy, Portugal and Spain) and moving to Northern European Member States, where the job market has remained attractive in spite of the crisis (Belgium, France, Germany, United Kingdom). In other words, this book seeks an answer to the following question: have old South-North migration routes within Europe reopened?

More precisely, our objective for this volume is twofold. First, we intend to identify the scale and nature of this new Southern European wave of emigration and the socio-economic integration of these migrants within Northern European destination countries. This will be achieved through a quantitative analysis of the most recent data on the flows and profiles of this new labour force using databases from both sending and receiving countries (labour force surveys, census records, migration office statistics on national and EU levels, Eurobarometer surveys, etc.). Such analysis will, overall, point to the differences and similarities between this current wave of Southern European migration and previous ones. However, as the different chapters in this volume show, quantitative data often presents limitations that invite us to use such information with great care. For instance, the measurement of the migration flows of EU citizens can be undermined by the voluntary non-registration of EU migrants with the authorities in both the home and the host country. EU migrants do not have a strong incentive to register as permanent residents in the host country. In fact, they may have important reasons not to deregister as residents in their home country; for example, to avoid losing entitlements to health care provision, social security rights or unemployment insurance, amongst others. Alternatively, not registering with the host country authorities may be a conscious strategy by EU citizens concerned about the removal of their residence permit if they are in a financially precarious situation (see Chap. 7). In addition, the circular nature of migratory moves applies to a non-negligible number of Southern Europeans. Some migrants may thus not be interested in registering upon arrival if they plan a short-term stay. Such data limitations entail the possibility that recent migrants-like the newly arrived Southern Europeans - are under-represented in official data, while longerterm migrants, who arrived well before the crisis, are over-represented. As underlined in Chap. 8, well-settled migrants with stable housing and jobs are more likely to be included in large surveys such as the Labour Force Survey than are new migrants in a precarious housing situation.

Second, this book will look at the politics and policies of immigration from the perspective of both the sending and the receiving nations. Because of the uncertainties regarding the profile and motivations of those who leave their home country, Southern European governments have been speculating on the impact of this loss of labour force and on the appropriate policy response to adopt. Similarly, Northern European governments have had mixed attitudes towards this new influx of EU citizens. Reactions in Northern Europe have varied: some countries have set up programmes to actively recruit and train these migrants, while others have promulgated the stigmatization of mobile EU citizens. In this volume, each chapter has designed 
its own methodological approach to capture the policies and debates triggered by these new flows, but press and parliamentary documents have also been a privileged source used to make sense of these most recent evolutions. This approach shows how contentious the issue of intra-EU mobility is, even when it concerns citizens from EU-15 Member States whose right to move within the EU had not previously been questioned for several decades.

Overall, the strength of this edited volume is to compile in a systematic way a quantitative and qualitative analysis of these renewed Southern European migration flows. As this new wave of emigration has triggered debates and policy responses at the local, national and EU level, this book thus seeks - through a systematic analysis of these case studies - to shed light on the lessons that can be learned from this changing climate in EU migration.

\subsection{Conceptualizing Crises and Migration}

Crises are generally considered as "turning points" (Alink et al. 2001, 300) that trigger social phenomena-like migration-as well as public policy reforms. In the field of migration, economic crises are traditionally considered as opportunities to implement restrictive immigration policies. For instance, the Great Depression of the 1920s and the Oil Crises of the 1970s were both occasions during which states implemented stronger barriers to immigration. Scholars have noted that the 2008 financial and economic crises triggered two important transformations: migration policies have evolved at a rapid pace and migration flows have been taking new forms (Papademetriou and Terrazas 2009; Papademetriou et al. 2009; Cerna 2013).

First, with regard to policy-making, the economic crisis has prompted the public authorities of many Member States to adopt increasingly strict migration and integration policies. For authors such as Kuptsch $(2012,19)$, migration policy reforms in receiving countries during the global economic crisis have consisted mostly of four types of measure: making new immigration more difficult, protecting native workers from the perceived competition of foreign workers, adopting programmes and measures to encourage return migration and clamping down on irregular migrants. But while the connection between crises and stricter migration policies is appealing, the causal link is not always obvious. Considering that migration policies in Europe were already becoming stricter before the crisis, it remains unclear whether or not many of the reforms that are described in this book would have been adopted without the occurrence of the crisis. In other words, we should be aware of the risk of focusing on endogenous or exogenous events as simplistic explanations for migration policy reforms.

Defining crises and theorizing their role in policy-making is not an easy endeavour. One possible point of departure to understand the effect of the 2008 financial and economic crisis is thus to determine what defines a crisis and to identify the lines according to which this definition may vary. Nohrsted and Weible (2010, 3) have noted that crises are usually considered as "periods of disorder in the seemingly 
normal development of a system and widespread questioning or discrediting of established policies, practices, and institutions". Yet, the nature of a crisis may differ according to certain variables. First, a crisis may be caused by either an internal or an external shock. For policy-makers, the geographic scale at which stimuli for policy reforms occur necessarily affects their ability to react. The intensity of the crisis provides the second line of variation. Crises - whether global or not - do not necessarily produce similar social, economic and political effects, nor do they affect equally all states to the same extent. However, existing research has not yet identified any correlation between the scale of a crisis and the importance of the reforms adopted in reaction to it. Third, crises also trigger diverse responses according to policy-makers' prerogatives and, most importantly, according to their subjective interpretation of what is an appropriate response to the crisis. As we will see in the volume, several EU Member States have been severely hit by the 2008 financial and economic crisis. Yet, in spite of the broadly similar effects of the crisis on their socio-economic situations, states have reacted by adopting reforms in different policy areas or even by adopting diverging reforms within the same policy area.

The understanding of crisis-related migrations is further complicated when migration flows are themselves considered as crises. For instance, the growing influx of migrants and asylum seekers in the summer of 2015 has clearly been framed as an "immigration crisis" by both policy-makers and observers alike. Attaching the concept of crisis to flows rather than to their causes has important consequences on the policy-makers' agenda: instead of tackling the social, political or economic root causes that trigger migration, policy reforms tend to focus solely on reducing flows to pre-crisis levels.

Alongside the critical approach to the concept of crisis that we aim to adopt in this volume, we also intend to be equally critical of the concepts used to describe the migration flows occurring during the recession. Our objective in this book is to concentrate on internal flows within the European Union, which we refer to interchangeably as mobility and migration.

As noted by Aybek and colleagues (2015), mobility and migration studies have historically different origins. Mobility studies have emerged in a context of progress in communication and transportation technologies since the late twentieth century. From this perspective, international migration-defined as long-term relocation across an international border - is just one among several possible transformations in people's lives (along with long-distance commuting or internal migration for instance). Similarly, King and Skeldon (2010) invite us to consider the segmentation between internal mobility - usually understood as short-distance internal migration - and international migration research as artificial. Indeed, the existence of international migration is highly dependent on the definition of borders which are social constructs that are likely to change over time (Favell 2007). The fact that post-war Southern European guest workers progressively became mobile EU workers as their home state took part in the European integration process is a good illustration of how political projects can change the vocabulary used to describe people on the move (see Chap. 2). 
In contemporary Europe, the concept of mobility is thus frequently used in public debates and policy circles to describe changes of residence from one EU Member State to another, whereas the concept of migration denotes the arrival within the EU of citizens proceeding from third countries (Glorius et al. 2013). However, in this book, the terms mobility and migration are both used to reflect changes of residence of EU citizens between different Member States. Combining these terms acknowledges that -in spite of both the specific context in which it occurs and its diverse characteristics - new Southern European migration presents some similarities with older twentieth century flows proceeding from those countries, with more recent flows from other parts of the EU but also with flows proceeding from outside the EU. This conceptual choice therefore aims to go beyond the implicit qualitative assessment hidden behind these two terms in policy debates according to which mobility - unlike migration - refers to voluntary and mostly desirable movements of EU citizens. By looking at the conditions in which Southern EU citizens decide to leave their home country and the treatment that some of them receive upon arrival in destination countries, we shall thus reconsider the validity of such an assessment.

This conceptual choice does not, however, lead us to consider EU internal migration and immigration of third country nationals to the EU as fully equivalent phenomena. Differences obviously remain in the context of departure and in the legal framework regulating the crossing of borders and access to the labour market. Even within the category of EU migrants, diversity also prevails: research has shown a multiplicity of socio-economic profiles, ranging from individuals belonging to the North Western European middle class (Recchi and Favell 2009) to blue collar workers from Central and Eastern Europe (Black et al. 2010). Furthermore, as shown very clearly through different typologies produced on new Central and Eastern European migration, categories of EU migrants that are sometimes perceived as relatively homogenous continue to display varying degrees of attachment to both their sending and receiving societies (Engbersen and Snel 2013). Based on this experience, this volume has taken great care to avoid presenting new Southern EU migrants as a homogeneous group, in spite of the various characteristics they may share.

\subsection{Migration Flows in Times of Crisis and the Resulting Policy Responses}

As this volume will demonstrate, migration flows in the European Union have changed during the economic crisis. In spite of growing unemployment, protectionism and xenophobia in destination countries, migration flows have not uniformly decreased in the EU. Focusing on the migration dynamics between Southern and Northern European Member States is particularly revealing of this diversification. 
With the crisis, migration of EU citizens to other Member States has been on the rise: around eight million economically active EU citizens live in another Member State, representing $3.3 \%$ of the labour force in 2013, compared to $1.6 \%$ in 2004 and $2.4 \%$ in 2008 (European Commission 2014b). While South-North migration of EU citizens significantly increased during this period, East-West migration within the EU - a phenomenon that preceded the crisis - did not significantly slow down during the same period (Kaczmarczyk 2014; Zaiceva and Zimmermann 2016). Similarly, the migration of third country nationals fleeing their homeland to enter the EU due to political or economic instability has also continued (Fargues and Frandrich 2012), and numbers increased significantly in 2015. This means that, overall, although some migration flows may have significantly decreased with the economic crisis (e.g. Romanian migration to Spain), other flows have continued almost unaffected by the recession, increasing or even reappearing after we thought they were in decline.

In explaining the renewed Southern European migration to Northern Europe, many observers have identified two crisis-related factors. First, high unemployment in the Southern EU Member States most affected by the crisis has pushed some of their nationals to look for employment opportunities abroad (either in Northern Member States or outside the EU). Similarly, many third-country migrants living in these countries have also either returned to their home countries or emigrated again to another country (see Chap. 6 on Spain). Second, rising levels of social exclusion and changing labour market conditions are another trigger for emigration. In Southern Europe, labour market reforms and cuts in wages have also rendered the position of many workers more vulnerable. Overall, it is worth noting that the share of non-mobile EU citizens at risk of poverty or social exclusion increased during the crisis and reached $22.8 \%$ in 2013 (European Commission 2014a). In other words, beyond unemployment, increased social risks and bleak prospects offered by the labour market in Southern Europe may explain why individuals who held jobs during the crisis still went to look for alternative employment abroad.

Even though labour market conditions have worsened and social exclusion has clearly increased, this volume questions the role of the crisis as the sole factor explaining contemporary Southern European migration to Northern Europe. It does this in three ways. First, we examine South-North EU migration flows as long-term processes whose origins precede the crisis. The case of Portugal (see Chap. 5) best epitomizes this element. In Southern Europe, the intensification of departures often preceded the financial and economic crisis but received little interest for years because those flows were overshadowed by larger influxes of foreigners moving to these countries. For instance, in spite of the continuation of emigration throughout the 2000s, it is only when foreign immigration into Portugal stopped that the country started to think of itself again as an emigration country. Framing all contemporary migrations from Southern Europe as crisis-related flows might therefore hide a more complex reality: certain profiles of migrants - such as low-skilled workers were already moving before the crisis, which in itself only served to intensify the phenomenon. 
Second, labour market segmentation and an increased risk of social exclusion also find their roots prior to the crisis. In recent years, many Member States have undertaken reforms to curb social expenditure as part of their fiscal consolidation efforts. This has led to cuts in the levels of social protection benefits/services in some countries as well as efforts to restrict access (European Commission 2014a). Some of these reforms, however, preceded the crisis. Moreover, and most importantly, the process of segmentation of the labour market had been initiated long before the crisis, but it was seen subsequently to accelerate with the crisis. As shown very clearly in the case of Italy (Chap. 4), disparities in social protection between the precarious youth and older well-protected workers are long established. In Member States such as Germany and the United Kingdom, the numbers of workers in temporary and precarious low-paid jobs were already significant before the crisis. Despite the fact that these countries have exhibited better resistance than others to the effects of the economic crisis, the share of workers occupying such jobs there has similarly risen significantly during the crisis (see Chaps. 9 and 10).

\subsection{New Migration, New Controversies and New Responses}

While South-North migration is not at all a new phenomenon, we will demonstrate in this volume that the context in which it is occurring nowadays renders this new wave more controversial than previous ones. In addition to the deterioration of European economies and the changing conditions of the labour market described above, the legal and political contexts in which those migrations are occurring are significantly different from that of twentieth century guest worker programmes. First of all, the EU integration process has removed many administrative barriers to migration, but only for some migrants within the EU. Post-war guest workers proceeding from countries like Italy, who later became Member States of the European Community, have progressively enjoyed more rights than those coming from third countries like Morocco. Yet, these early migrants had arrived in Europe under broadly comparable regulations before World War II. As shown in Chap. 7 (Belgium), the favourable economic context in which those migration flows occurred and the legislative framework that supported the political integration of those migrants greatly contributed to their integration. For this reason, post-war Southern European migrants were often referred to as "desirable migrants" in contemporary debates of the time.

As shown by Roxana Barbulescu in Chap. 2, progressive EU enlargements seem to have eroded the support of political elites for the principle of freedom of circulation in different parts of Northern Europe. This means that new Southern European migrants are not necessarily able to capitalize on their predecessors" "success" when moving North. This can be explained by the importance of East-West migration flows following the enlargement to EU-10 countries and the progressive lifting of restrictions on the freedom of circulation of their citizens. In spite of the fact that overall migration within the EU has remained limited, the intensification of specific 
flows of migrants to particular places has triggered tensions over issues such as social dumping and access to housing and social services in certain localities.

In particular, the use of social protection entitlements by EU migrants and third country nationals has become increasingly controversial in the context of the crisis. In different Member States, such as Belgium and the United Kingdom, governments have not only reduced the ability of immigrants to claim benefits in these countries, but they are also increasingly depicting EU and third-country migrants as "abusers" of their social protection systems (see Chaps. 7 and 10) and as "unreasonable burdens" on their public finances. In spite of their existence for several decades, the resurgence of the concepts of "welfare magnets" or "welfare shoppers" to delegitimize immigrants' access to social protection is, however, not surprising in a context of crisis when states are looking at ways to decrease public spending (Böhning 1972; Borjas 1998; Schierup et al. 2006; De Giorgi and Pellizzari 2009; Giulietti et al. 2013).

Few specific academic reports have responded directly to the new wave of accusations regarding the fiscal cost of migration (Dustmann and Frattini 2013). Nevertheless, studies on the fiscal impact of migration, developed by international organizations such as the European Commission (EC) and the Organization for Economic Co-operation and Development (OECD), have pointed out that - in spite of the fact that measuring the impact of migration is rendered complicated by the diversity and large number of policies to which immigrants contribute - the impact of migration on public finances is very frequently positive (European Commission 2013; OECD 2013). At the political level, the Commission has also repeated in different communications made by its Commissioner responsible for employment, social affairs and inclusion that freedom of circulation concerns only a small minority of EU workers. Moreover, the migration resulting from this freedom generates wealth inside the Union and, most importantly, it is a founding principle of the EU about which the Commission is not willing to make concessions (European Commission 2014c).

Following the terms of Directive 2004/38/EC on the free movement of EU citizens, Member States have, however, recently started to pay particular attention to the provision allowing the removal of residence permits from EU nationals in need of social assistance, i.e. those who represent a "burden" on the public finances of the host state. As several states are now aiming to reduce the number of foreigners receiving benefits in times of crisis, this practice is gaining traction. At the same time, a likely consequence of this practice is that numerous EU migrants will refrain from making use of their right to social protection, due to a lack of knowledge about these benefits or for fear of losing their right to residence. This is particularly concerning since, in $2013,48.7 \%$ of third-country migrants aged 18 and over residing in the EU-28 and $28.1 \%$ of EU migrants were at risk of poverty or social exclusion.

Member States that are receiving this new wave of Southern European migrants are, however, not unanimously rejecting it. As shown by Klekowski and Höhne in 
Chap. 9, Germany, for instance, has adopted specific measures to encourage the migration and integration into the labour market of young European migrants. These programmes, which were advertised in Southern Europe, caught the attention of thousands of young Spaniards, who moved to Germany with a contract guaranteeing an apprenticeship and language classes. While this programme is limited in scale, it clearly illustrates the fact that the crisis has also represented an opportunity for certain industries facing shortages of skilled workers. While it represents a basic application of the principle of freedom of circulation within the EU, the attraction of Southern European talent to Northern European labour markets triggers its own set of controversies. First, as shown in Chap. 9, the risk continues that, due to difficulties involved in the recognition of qualifications across Europe, some highlyskilled Southern European migrants might end up working in jobs that do not maximize their skills (i.e. leading to "brain waste"). Second, by recruiting explicitly qualified workers, will Northern European Member States not be undermining the ability of Southern European countries to recover from the crisis?

These questions have been raised in countries of both destination and origin. As shown in the four Southern European case studies in this edited volume, the authorities in sending countries have reacted very differently to these new flows. On the one hand, Portugal and Italy have debated the issue of emigration in Parliament and their emigration-related authorities (e.g. consultative councils on emigration) have brought the issue onto the national agenda. However, as shown by José-Carlos Marques and Pedro Góis in Chap. 5, in the case of Portugal, the issue of emigration is being used in the domestic political arena to support or question the management of the economic crisis by the authorities. On the other hand, Spain and Greece appear to have been less reactive, in spite of the large emigration waves of recent years. In the case of Spain, in particular, Bermudez Torres and Brey's chapter (Chap. 6) shows clearly that acknowledging the very existence of crisis-related emigration is a controversial topic. The Spanish government's uneasy position on these flows epitomizes the dilemma faced by sending states. On the one hand, recognizing the existence of crisis-related flows is a necessary step towards addressing some of the difficulties encountered by citizens abroad and preparing for their possible return when the socio-economic context improves. On the other hand, denying the existence of such flows is a way to avoid politically damaging debates on the responsibility by the governments of sending countries in creating those new migration waves.

\subsection{Structure of the Book}

Following this introduction, which has conceptualized the issue of South-North migration of EU citizens in a time of crisis, Chap. 2 tracks down the evolution of freedom of movement within the $\mathrm{EU}$ and documents its retrenchment in the context of the crisis. In that chapter, Roxana Barbulescu argues that-even though it is the 
mobility of Eastern European citizens that has triggered negative reactions and restrictive policies - this new mobility has very concrete and serious consequences on new Southern European migrants.

Chapters 3, 4, 5, 6, 7, 8, 9, and 10 are country-specific chapters containing case studies looking at the issue of South-North EU migration from the perspective of selected sending and receiving nations. This approach deserves two comments. First, while we agree that such a state-centred approach may give the wrong impression that these new flows are unilateral and permanent, we also felt that it would provide us with the right angle to identify the specific issues and varying reactions being triggered by this new mobility in different parts of Europe. Furthermore, given the aforementioned difficulties in measuring flows between EU countries, we consider that using sending and receiving country data provides the reader with a more complete and accurate description of this phenomenon.

Second, because this volume does not have a purely comparative ambition, the eight countries under study were selected along two lines. The four sending countries featured in this volume were selected from among the group of Member States most severely hit by the crisis. Because of the diverse socio-economic situations between countries like Greece and Italy, the relevance of the category of "Southern European Member States" could, however, be called into question. This is particularly true when we think of Ireland or the Baltic states, which have experienced very similar difficulties during the crisis. Yet, we maintain that the category of Southern European Member States is a valid unit of analysis because of the common history of twentieth century migration from those countries to Northern Europe. In several cases, these migration flows has been associated in public discourses with successful integration processes (see D'Amato 2005; Safi 2006; Martiniello 2013). This contrasts strongly with the current distrust and sometimes opposition towards new European migrants in most Northern European Member States.

The capacity of Northern Europe to remain - in spite of variations from case to case - an attractive destination area for immigrants explains the geographical focus of this volume. Naturally, this part of Europe has also been affected by the crisis but with varying degrees of intensity and different timings. The four receiving countries studied in this volume-Belgium, France, Germany and the United Kingdomhave been selected not only because of their better economic performance during the crisis compared to Southern European EU countries but also because their governments have reacted differently to the economic crisis and, most importantly, to the new influx of Southern European migrants. Whereas Belgium and the United Kingdom have reacted mostly with hostility, France could be qualified as being indifferent and Germany very encouraging towards specific types of new Southern EU migrants.

In Chap. 3, Georgia Mavrodi and Michalis Moutselos show that the skills, migratory paths and numbers of recent migrants are quantitatively and qualitatively different from those of post-war migration. Meanwhile, elite discourse around new migration has mostly been anchored to the debates for/against austerity and no targeted policies have been developed to facilitate the trajectories or the return of the new migrants. This contrasts very strongly with the case of Italy, as discussed in 
Chap. 4 by Guido Tintori and Valentina Romei. The authors question the idea of a brain drain from the country in favour of a more balanced approach, which takes into consideration the diversity of profiles among new emigrants. With this approach, the authors examine how the sense of political alert about a possible brain drain intertwines with post-crisis labour market reforms. Chapter 5 by José Carlos Marques and Pedro Góis questions the concept of crisis-related migration by showing that Portuguese emigration was already a significant phenomenon before the crisis but that this has been ignored because of the policy-makers' focus on immigration into Portugal. Their chapter also shows that, while Portugal has had a tradition of engaging with its citizens abroad, limited actions have been taken to assist new emigrants beyond alarmist discourses in Parliament. In this sense, the authors' conclusions are very comparable to those made in Chap. 6 by Anastasia Bermudez Torres and Elisa Brey, who also note a lack of engagement with, if not a sense of antagonism towards, new emigrants. In Spain, the very acknowledgement of the existence of crisis-related migration is a topic of contention between governing and opposition parties. Yet, in spite of the difficulty involved in measuring the exact number of emigrants and in differentiating them from return migrants, their account of the mobilization of new Spanish emigrants is very telling of the transformation of Spanish communities in Northern Europe.

The next four chapters reverse the perspective and look at how new Southern European migrants have been received and at the policies, controversies, or indifference they have generated. In Chap. 7, Jean-Michel Lafleur and Mikolaj Stanek show how favourable Belgium could have been in principle to new Southern European migration because of the positive image associated with twentieth century Italian migration. However, a large influx of Central and Eastern European migrants to Belgium, coupled with the economic crisis, have decisively transformed policymakers' rhetoric towards EU migrants. As the authors show, this hostility has recently developed into a policy - which has particularly hit Southern European migrants - of the systematic removal of residence permits from EU citizens who make use of social assistance for extended periods of time.

On a similar theme, Chap. 10 on the United Kingdom, by Alessio D'Angelo and Eleonore Kofman, describes how social policies are increasingly being used as a substitute for migration policies by Member States. The UK, however, is the first destination country for tertiary educated, Southern European migrants. The UK is also characterized by a political and policy context of anti-immigration sentiment in the mainstream political discourse, often conflated with a criticism of the EU system of free movement. Chapters 8 and 9 offer very different accounts of Southern European migration. In Chap. 8, Amanda Klekowski von Koppenfels and Jutta Höhne discuss the top-down and bottom-up recruitment of skilled Southern Europeans by Federal Employment Agencies, regional offices, trade associations and employers themselves during the crisis. In spite of emerging xenophobic discourses that exist in countries receiving Southern Europeans, the authors show that this new migration has mostly been framed as part of the response to a lack of skilled workers, as well as contributing to a resolution of the emerging demographic challenges. In Chap. 9, Tatiana Eremenko, Elsa Steichen and Nora El Qadim con- 
firm the diversity of profile in the new Southern European migration. They underline the fact that recent controversies and regulations concerning migration in France have spared Southern Europeans, but have focused instead on third country and EU citizens from Central and Eastern Europe.

To conclude this volume, two chapters draw the most important lessons from the case studies. In Chap. 11, Jean-Michel Lafleur, Mikolaj Stanek and Alberto Veira attempt to find an answer to the question of whether we are witnessing the reopening and repetition of previous South-North migration waves from the 1950s, 1960s and 1970s. In this process of cross analysis of data from the different chapters, the authors identify the main features of both the current and previous waves of migration. They also analyse the social and economic context in which the new SouthNorth migration has been taking place. The authors argue that although the South to North migratory route has been re-established during the recent economic crisis, there are several features that make the previous and current migration waves barely comparable. Finally, in Chap. 12, Jean-Michel Lafleur and Mikolaj Stanek build on the different case studies, to identify five main lessons emerging from the renewed migration flows of Southern European EU citizens. The authors argue that evidence from the multidimensional exploration of new South-North migration contained in this volume shows that while new Southern European migration has not been the most important migration phenomenon in Europe in the past decade, its study is key to understanding contemporary migration dynamics within the EU.

Overall, this book brings to light several issues that, to date, have not always been clearly and explicitly addressed or assessed within the context of intra-EU mobility. Among other issues, it reaffirms that migration is not only a strategy for individuals and households but also for governments to deal with the deterioration of their country's employment situation. It also demonstrates increasing segmentation in both access to freedom of circulation and access to certain welfare provisions, which varies according to the nationality of EU migrants. Finally, it shows that the already fragile balance between labour supply and productive structure in Southern European EU countries might be affected by the outflow of highly skilled workers.

\section{References}

Alink, F., Boin, A., \& T'Hart, P. (2001). Institutional crises and reforms in policy sectors: The case of asylum policy in Europe. Journal of European Public Policy, 8(2), 286-306. doi:10.1080/13501760151146487.

Aybek, C., Huinink, J., \& Muttarak, R. (2015). Migration, spatial mobility, and living arrangements: An introduction. In C. Aybek et al. (Eds.), Spatial mobility, migration, and living arrangements (pp. 1-19). Heidelberg: Springer.

Black, R., Engbersen, G., Okólski, M., \& Panţîru, C. (2010). A continent moving west? EU enlargement and labour migration from Central and Eastern Europe (IMISCOE Research Series). Amsterdam: Amsterdam University Press. 
Böhning, W. R. (1972). The migration of workers in the United Kingdom and the European Community. London: Oxford University Press.

Borjas, G. J. (1998). Immigration and welfare magnets. Journal of Labor Economics, 17(4), 607-637.

Cerna, L. (2013). Understanding the diversity of EU migration policy in practice: The implementation of the blue card initiative. Policy Studies, 34(2), 180-200. doi:10.1080/01442872.2013.76 7587.

D'Amato, G. (2005). How the Italians became blond! Immigration and political rights in France, Switzerland and Germany. Studi Emigrazione, 160, 822-846.

De Giorgi, G., \& Pellizzari, M. (2009). Welfare migration in Europe. Labour Economics, 16(4), 353-363.

Dustmann, C., \& Frattini, T. (2013). The fiscal effects of immigration to the UK. Discussion paper Series CReAM. CDP, 22(13).

Engbersen, G., \& Snel, E. (2013). Liquid migration. Dynamic and fluid patterns of post-accession migration flows. In B. Glorius, I. Grabowska-Lusinska, \& A. Kuvik (Eds.), Mobility in transition: Migration patterns after EU enlargement (pp. 21-40). Amsterdam: Amsterdam University Press.

European Commission. (2013). European Commission upholds free movement of people, European Commission Memo. http://europa.eu/rapid/press-release_MEMO-13-1041_en.htm. Accesed 15 Oct 2015.

European Commission. (2014a). Employment and social developments in Europe. http://ec.europa. eu/social/main.jsp?catId=738\&langId=en\&pubId=7684. Accessed 8 Nov 2015.

European Commission. (2014b). EU employment and social situation quarterly review. Recent trends in the geographical mobility of workers in the EU.

European Commission. (2014c). Labour mobility in the EU: Challenges and perspectives for $a$ genuine European labour market. Lecture by László Andor.

Fargues, P., \& Frandrich, C. (2012). Migration after the Arab Spring (MPC Research Report, Vol. 2012/09). San Domenico di Fiesole: European University Institute.

Favell, A. (2007). Rebooting migration theory: Interdisciplinarity, globality, and postdisciplinarity in migration studies. In C. Brettell \& J. Hollifield (Eds.), Migration theory: Talking across disciplines (pp. 259-278). New York: Routledge.

Giulietti, C., Guzi, M., Kahanec, M., \& Zimmermann, K. (2013). Unemployment benefits and immigration: Evidence from the EU. International Journal of Manpower, 34(1), 24-38.

Glorius, B., Grabowska-Lusinska, I., \& Kuvik, A. (2013). Introduction. In B. Glorius, I. GrabowskaLusinska, \& A. Kuvik (Eds.), Mobility in transition. Migration patterns after EU enlargement (pp. 7-17). Amsterdam: Amsterdam University Press.

Kaczmarczyk, P. (2014). Labour mobility in the EU: Dynamics, patterns and policies: EU enlargement and intra-EU mobility - Lessons to be drawn from the post-2004 migration of poles. Intereconomics, 49(3), 128-136.

King, R., \& Skeldon, R. (2010). Mind the gap! Integrating approaches to internal and international migration. Journal of Ethnic and Migration Studies, 36(10), 1619-1646. doi:10.1080/1369183X.2010.489380.

Kuptsch, C. (2012). The economic crisis and labour migration policy in European countries. Comparative Population Studies, 37(1-2), 15-32. doi:10.4232/10.CPoS-2011-17en.

Martiniello, M. (2013). Belgium, migration, 1946 to present. In The encyclopedia of global human migration. Hoboken: Blackwell Publishing Ltd.

Nohrsted, D., \& Weible, C. (2010). The logic of policy change after crisis: Proximity and subsystem interaction. Risk, Hazards, \& Crisis in Public Policy, 1(2), 1-32. doi:10.2202/1944-4079.1035.

OECD. (2013). International migration outlook: SOPEMI 2013. Paris: OECD Publishing.

Papademetriou, D., \& Terrazas, A. (2009). Immigrants and the current economic crisis: Research evidence, policy challenges, and implications (Migration Policy Institute Working Paper). 
Washington, DC: Migration Policy Institute. http://www.migrationpolicy.org/pubs/lmi_recessionJan09.pdf. Accessed 8 Nov 2015.

Papademetriou, D., Sumption, M., \& Somerville, W. (2009). Migration and the economic downturn: What to expect in the European Union (Migration Policy Institute Working Paper). Washington, DC: Migration Policy Institute. http://www.migrationpolicy.org/research/ migration-and-economic-downturn-what-expect-european-union. Accessed 10 Nov 2015.

Promberger, M., Huws, U., Dagdeviren, H., Meier, L., Sowa, F., Boost, M., et al. (2014). Patterns of resilience during socioeconomic crises among households in Europe (RESCuE)- concept, objectives and work packages of an EU FP 7 project. IAB-Forschungsbericht, 05/2014.

Recchi, E., \& Favell, A. (2009). Pioneers of European integration: Citizenship and mobility in the $E U$. Cheltenham: Edward Elgar.

Safi, M. (2006). Le processus d'intégration des immigrés en France: inégalités et segmentation. Revue Française de Sociologie, 47(1), 3-48.

Schierup, C.-U., Hansen, P., \& Castles, S. (2006). Migration, citizenship, and the European welfare state: A European dilemma. Oxford: Oxford University Press.

Zaiceva, A., \& Zimmermann, K. F. (2016). Returning home at times of trouble? Return migration of EU enlargement migrants during the crisis. In M. Kahanec \& K. F. Zimmermann (Eds.), Labor migration, EU enlargement, and the great recession (pp. 397-418). Berlin, Heidelberg: Springer.

Open Access This chapter is licensed under the terms of the Creative Commons AttributionNonCommercial 2.5 License (http://creativecommons.org/licenses/by-nc/2.5/), which permits any noncommercial use, sharing, adaptation, distribution and reproduction in any medium or format, as long as you give appropriate credit to the original author(s) and the source, provide a link to the Creative Commons license and indicate if changes were made.

The images or other third party material in this chapter are included in the chapter's Creative Commons license, unless indicated otherwise in a credit line to the material. If material is not included in the chapter's Creative Commons license and your intended use is not permitted by statutory regulation or exceeds the permitted use, you will need to obtain permission directly from the copyright holder.

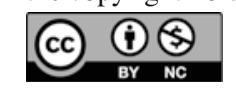




\title{
Chapter 2 \\ From International Migration to Freedom of Movement and Back? Southern Europeans Moving North in the Era of Retrenchment of Freedom of Movement Rights
}

\author{
Roxana Barbulescu
}

Whatever the weather, we must move together. (Message on poster popularising the Marshall Plan, 1950)

\subsection{Introduction}

Europeans have always moved to European neighbouring countries to battle wars, study, work or start a family. Over time, mobility on the European continent has changed remarkably: if in the postwar period, Southern Europeans were recruited as guest workers via bilateral agreements established between states, the creation of freedom of movement allowed people to migrate freely and on their own choice. The consolidation and extension of freedom of movement rights continued as the European Union has grown "ever closer", it gradually extended from workers and their families to include students, retirees, job seekers and every European Union citizen with sufficient financial resources to support her/his stay. Over time freedom of movement has gradually evolved in a form of international migration unique in the world which, encompasses a population of half a billion people and 32 countries (EU28, EEA and Switzerland). In the context of the economic crisis that has started in 2007, citizens and political elites in several member states are challenging in systematic manner the principle of freedom of movement for the first time. At the EU level too, the hitherto progressive expansion of rights for freemovers which culminated with the introduction of Directive 38/2004 was stopped after in mid 2000s.

\footnotetext{
R. Barbulescu (ه)

ESRC Centre for Population Change and Department of Sociology, Social Policy and Criminology, University of Southampton and College of Europe (Natolin Campus),

Warsaw, Poland

e-mail: r.barbulescu@ soton.ac.uk
} 
This chapter examines the transformation of freedom of movement as a particular policy area at the supranational, European level and then moves on to document and discuss the political and policy responses to the intensification Southern Europeans' migration to Northern Europe in times of economic crisis. It starts by process-tracing the evolution of the freedom of movement regime from the guest worker schemes, the hallmark of European labour mobility in postwar period. It then moves to its period of intense consolidation and Europeanisation at the policy and political level. Finally, it zooms-in how and to what extend this past trends have changed after the last two enlargements and the new South-North migration triggered by the economic crisis. The chapter argues that the new South-North migration is taking place in an era of retrenchment of freedom of movement rights. The recent Eastward enlargements drive the political contestation of freedom of movement rights and together with the worsening of economic conditions in NorthWestern EU countries have led to policy changes that effectively contract the rights of freemovers. Such retrenchment of rights announce the end of a "golden era" of freedom of movement as it becomes increasingly similar with international migration from third countries. The ongoing changes negatively affect all European citizens including Southern Europeans moving in the EU since the start of the economic crisis. In particular, the young Southern Europeans who have been socialised and experienced Europe as a continent of free mobility because the contraction of rights comes at the time when they most need mobility rights to escape the financial and economic crisis in their countries.

\subsection{South-North Mobility in the Postwar Europe: Guest Workers on Old Migratory Routes}

In the postwar period, many Southern Europeans went to work in the more industrialised countries in the North of Europe as guest workers (Castles and Kosack 1973; Piore 1979; Hammar 1985; Messina 2007). War-ridden economies North-Western European countries recruited workers from a variety of countries but focused primarily on the Mediterranean basin - Italy, Greece, Spain, Portugal, as well as Yugoslavia, Turkey and Northern African countries - and their former colonies. Southern Europeans were amongst the most numerous migrant community in the countries. For example, in 1980, in Western Germany, Southern Europeans represented over a quarter of all foreign workers (Italians made up $14 \%$ of all foreign workers, Greeks 6.6\%, Spaniards $4 \%$ and Portuguese $2.5 \%$ (Schmitter Heisler 1992: 39 and Chap. 9 in this volume). Belgium and France received similar high numbers of Southern Europeans in the same period (see Chaps. 7 and 8 in this volume). Elsewhere in North-Western Europe, Southern Europeans were also numerous. In the Netherlands, Southern Europeans who were categorised as 'Mediterranean' made up $1.1 \%$ of the total population of the country, with Spaniards rather than Italians being the most dominant, $0.8 \%$ or 123,000 (Rath and Sagar 
1992: 206). Compared with these countries, Britain was a deviant case in Northern Europe as it primarily recruited workers either from its colonies outside Europe or from and the Baltic states via the European Voluntary Workers Scheme (Kay and Miles 1988) There were, however, some exceptions. Italians workers concentrated in London and the large cities or in Bedford where they worked for the London Brick Company (see Chap. 10 in this volume).

As a rule, guest worker agreements were state-to-state deals that Southern European countries signed with France, Switzerland, and Belgium in the 1940s, and with Germany, the Netherlands, and Austria in 1950s and 1960s. The repeated recruitment in Southern Europe as well as the family members who soon joined the workers in Northern Europe carved a marked migratory route from the South to the North of Europe. In the Fordist-Keynesian regulation model, the guest worker scheme played an essential role. Imported foreign workers provided a secondary labour force. They offered Northern European countries a reliable and fast solution to shortages, an on demand 'army of reserve workers' as Marx called it ready to power heavy industries and presumably ready to return at the end of their contracts. More importantly and paradoxically, guest workers were also contributors to Northern European economies via flexible pay-as-you go schemes which offered few social entitlements during what has been called the golden era of the welfare state. The majority of guest workers in postwar Europe were male, blue-collar workers who found employment in high-unionised industries. They were the ideal protected workers especially in conservative-corporatist varieties in Northern Europe. Yet as native workers in similar positions benefited of extended protections, foreign workers found themselves on flexible welfare trajectories.

In 1973 and because of the Oil crisis, Germany suddenly stopped new recruitments and most Western European governments followed suit by 1974. By the 1980s, everywhere in Europe the old guest worker programmes came to a full stop: the foreign workers have gained either permanent permits, became citizens in the country where they lived or returned.

Envisaged as temporary programmes, guest worker schemes led instead to the permanent settlement of the postwar migrants. Rather than triggering a large-scale return migration of the postwar workers, worsening economic conditions made migrants remain in the country and bring their families. The Oil Crisis together with the major transition from industrial to service based economy caused high unemployment, and deregulated the labour market with the logic that it would create new jobs. In particular, unemployment hit hard precisely the sectors in which foreign workers originally were recruited: the heavy industry, manufacture and mining. Also, native workers were now competing shoulder-to-shoulder with foreign workers for flexible work contracts and with women who were increasingly gaining access to paid work. In practice, these macro-economic changes prevented new recruitments from abroad. It also meant that many of the guest workers themselves entered unemployment and were in need of social protection just as native workers.

From the perspective of post-1973 crisis, the guest worker scheme seem as exceptional as the economic conditions in which it was born. The shortages of 
labour force in key sectors of economy that characterised the early postwar years was the opposite of high unemployment that swept across North-Western Europe in 1970s and 1980s just as much as generous state investment for reconstruction funds including the multibillion dollar Marshall Plan was the opposite of the debt states accumulated in the Oil Crisis. In fact, they seemed so unlikely that in 1986, the migration scholar Stephen Castles (1986) wrote 'an obituary' of the guest worker scheme in International Migration Review.

The crisis had different impact for different communities of guest workers. Amersfoort et al. (1984) find that that unlike the Turks, Tunisians and Moroccans, the migrants from Spain, Italy, Portugal and former Yugoslavia had high return rates. Moreover, emigration statistics of these countries report that departures declined significantly since 1973. Studying the effect of the Oil Crisis on migration within European Union and the Nordic Community, Rinus Penninx (1986) notes that the only generalizable trend is that new inflows "seem to diminish, if the free circulation zone as a whole is going through a period of stagnation or recession, ultimately, this leads to a less rapidly growing foreign population of member states" (1986: 957). On return migration, however, Penninx finds no general trend. For instance, the Portuguese community decreased in Western Germany and in France but it stabilized in Norway and the Netherlands and it increased in Luxembourg.

However, for Spain, Greece and to some extent Italy return migration was somewhere more significant. Return was driven primarily by the accession of Spain and Greece to the EU and Italy's miracolo economico of the 1960s. The Southern enlargement marked by the accession of Greece in 1981, Spain and Portugal together in 1986 had similar temporary restrictions introduced in the accession treaties as those applied for the Central and Eastern European states. In fact, the Southern enlargement was the first time the European Community enforced temporary restrictions on freedom of movement of people. The restrictions were imposed for a period of 6 years after each enlargement although Straubhaar (1984) noted they were scheduled initially to run for 7 years in the case of Spain and Portugal. The period was reduced because of the unexpected extremely low mobility of workers from these states. During the transition period, the number of Portuguese living in the EU increased by only 30,000 (3\%) while the number of Spanish citizens actually decreased by 25,000 (-5\%) (Dustmann et al. 2003: 44; Entzinger 1978).

Noteworthy is that there was no real end of Southern Europeans' migration story, no declaration or obituary was written for the South-North migratory route. The route did not disappear, it was transformed. While migration from the South to the North slowed down significantly, the same routes were used by the returning Southern Europeans as well as Northern Europeans moving South. Soon after the accession of the Southern European states to the EU (with the exception of Italy who was one of the six founding members), mobility patterns on this migratory route changed their character and parts of these flows became increasingly similar to North-North intra-European mobility. While certain migration patterns remained stable (see for instance low-skilled Portuguese migration in Chap. 5), new Southern European flows that had little in common with the postwar migration also emerged. Similarly to what had been observed in other parts of the EU, young and educated 
Southern European citizens headed to European cities in search for jobs but also to pursue cosmopolitan lifestyles and projects of self-realisation (Favell 2008; Recchi and Favell 2009). Finally, the emergence of a new migratory route in the reverse direction, running from the North to the South of Europe and the intensification of migrations from Central and Eastern Europe to both Southern and Northern Europe clearly indicated the decline of the South-North route.

Comparing the Southern Europeans' 'old' and 'new' migrations, one matter stands out. In the postwar Europe, they were able to work abroad because of the guest workers schemes while the more recent Southern Europeans have been able to move within the EU as Union citizens who enjoy freedom of movement rights. In the following section, I discuss the evolution of freedom of movement and its associated rights.

\subsection{The Archaeology of European Freedom of Movement: From International Migrants to Freemovers}

Some sort of freedom of movement exists for all people regardless of their nationality by virtue of holding a passport. However, not all passports are the same some passports carry different mobility rights across the world. Possessors of Afghan passports, for example, can travel freely to 28 countries at the same time that possessors of British, Finish and Swedish passports have near global mobility rights because they are able to enter freely to 173 of the 193 countries in the world (Henley and Partners Visa Restrictions Index 2013). The wide disparity in mobility rights has given rise what Stephen Castles (2005) calls "hierarchy of passports". However, the kind of mobility regimes passports establish is rather limited as it only secures free entry but guarantees no right to residence in the country, no rights for family members or other post-entry rights. Before the establishment of the European Community and freedom of movement, Europeans travelled under the same conditions as other international migrants using their passports and enjoyed limited rights once in the country. The emergence of a regional space for unrestricted mobility a profound change in the way the Europeans moved across the continent. Compared with similar regional projects such as NAFTA in North America, MERCOSUR in South America or the Euroasian Economic community, European freedom of movement of people stands alone because in the European case, mobility lies at the heart of the EU and together with the freedom of movement of services, goods and capital forms the four core freedoms of the Union. To recall the centrality of freedom of movement of people within the EU and the progressiveness of the regional integration project in Europe, Adrian Favell (2014) calls it "the fourth freedom" of the EU. Others, on the other hand, see it as an anachronism for the contemporary narrative on immigration. The editors of a leading EU law journal (Editorial Comments 2014) describe freedom of movement as a dream that turned into nightmare "legally over-complicated, politically abused allegedly costly and popularly 
misunderstood?'. Indeed, monitoring reports on the implementation of freemovers rights have revealed repeatedly irregularities with the transposition of the Directive in practice (Shuibhne and Shaw 2014). In April 2014, the European Commission acknowledged the problem and adopted the Directive 54/2014 that sets new rules to ensure better implementation of the rights of workers and jobseekers.

Freedom of movement is not only a generous mobility regime but it also generates additional rights including social rights in the member states of destination (Bauböck 2007; Kostakoloupou 2007; Maas 2007; Olsen 2008). Nonetheless, a notable absence is the lack of political rights for mobile Europeans in national elections although recent mobilisation in favour of these rights have found new momentum in the European public sphere (Shaw 2007; Barbulescu 2012; Baubock et al. 2012). The European freedom of movement therefore provides for ample entry and post-entry rights linked with residence which, create to a fairly unrestricted space human mobility within Europe. I underline fairly because it is not an absolute right. From the beginning, the treaties included safeguards that protect the interests of the member states from 'unreasonable burden' on the social assistance system (Article 14 of the Directive 38/2004) (see Chap. 7 on Belgium) and allow them to restrict freedom of movement on grounds of public policy, public security and public health (Article 27.1).

The freedom of movement of people was established at early stages of European integration. In its original definition in the Treaty of Rome (1957) it established under Article 3 'the abolition, as between the member states, of obstacles to freedom of movement of persons, services and capital' and took more than 10 years until it was implemented in 1968 with the Regulation 1612/1968. The policy was the result of convergence of interests between the Italy and the North-Western European countries, notes Moravcsik (1998: 149): "Italy sought to export labour and the other [Northern European], especially Germany, sought to import it, so it was easy to agree in principle on freedom of movement". Italy in particular argues Romero (1993: 52), was keen in signing off the policy because of the emerging European employment market provided with a solution to the chronic unemployment and poverty that led to Italians' mass emigration the turn of twentieth century (see Chap. 4, this volume). Paradoxically, the promise of freedom of movement for people announced in the Treaty of Rome that implied it would apply to all nationals was materialised into a labour mobility for workers in 1968. Peo Hansen and Stefan Jonsson (2014: 227-30) show that the change of wording from freedom of movement for nationals to workers was determined in the negotiation leading to what we now know as the Treaty of Rome. France requested to integrate Algeria, who at the time was part of Metropolitan France, to the European Community. In this case, Italy was amongst the opponents. Algeria's integration to the common market would have meant that its agriculture and especially Algerian workers who had French citizenship would now have competed with the Italian products and Italian workers. Algeria became an independent state before the implementation of freedom of movement but the early negotiations surrounding the Algerian case helped the member states understand that by replacing nationality with workers, they 
gained some leeway in deciding who qualifies for the worker status and under which conditions could they enjoy free mobility.

The initial introduction of freedom of movement of workers served both instrumental objectives of the European integration (Olsen 2008). At its early phase, integration focused on developing the economic advantages of the Union and on building the common market. Freedom of movement of workers complemented the freedoms of services, goods, capital and added substance to the common market. It also served the political objectives of the EU by creating a sense of unity, amongst the people of Europe, or a quasi-European demos and, therefore, legitimising the newly established Union.

Until the Treaty of Maastricht (1992), freedom of movement evolved consistently and progressively expanding the groups of EU citizens who could enjoy these rights from workers and their families to economically non-active people with sufficient economic means to support themselves. These changes were implemented through a series of European Community regulations 64/221/EEC, 68/360/EEC, 72/194/EEC, 73/148/EEC, 75/34/EEC, 75/35/EEC, 90/364/EEC, 90/365/EEC and 93/96/EEC throughout the 1980s and 1990s. Generally, the regulations sought to amplify the scope of the freedom of movement to include students, pensioners and economically autonomous people. The Treaty of Maastricht (1992) marked a milestone in the evolution of freedom of movement: it elevated the status of freemovers to citizens of the European Union and introduced new political rights for the mobile Europeans. Bellamy and Warleigh (2005) note that provisions made by the Treaty of Maastricht sought to substantiate the single market and tackle the democratic deficit between the citizens and the European elites. The freedom of movement expanded progressively until the mid 2000s when it culminated with the Directive 38/2004, also known as the 'Citizenship Directive'.

The Directive also established a right of permanent residence for Union citizens and did away with the exclusive relationship between freedom of movement rights and EU citizens by expanding them to third country nationals. Nevertheless, the latter were to benefit of these rights freely as did the EU citizens but only under extraordinary circumstances: if and only if third country nationals complied with certain conditions requested by the member states. This last addition corrected what William Maas (2008) has called the 'unfulfilled promised' of EU's citizenship: its inability to extend the rights that Union citizens enjoyed since 1950s to long-term legal residents from third countries. In other words, what the Citizenship Directive achieves was to take further the legacy of Maastricht by consolidating the scope of freedom of movement and by expanded its associated rights; but, crucially and most importantly the Directive marked a firm move from the economic logic of marketminded freedom of movement that dominated the European agenda until Maastricht to the nation-building project of 'making' citizens and setting the basis for a European political community.

In addition to the large number of regulations, guidelines, statements and communications from the European Commission, the Court of Justice of the European Union (CJEU henceforth) played an important role in interpreting the scope and limitations of both freedom of movement rights and Union citizenship through a 
vast jurisprudence on these matters. CJEU interpreted Union citizenship as destined to become the fundamental status rather than a complementary status to the national citizenship. A series of the Court's rulings ${ }^{1}$ have consolidated this interpretation over time. The most remarkable example of the "court-driven empowerment" (Joppke 2010: 171) of the Union citizenship is the CJEU's decision in the Grzelczyk ${ }^{2}$ case. The court reaffirmed the right of a French-national student, Rudy Grzelczyk, who after 3 years of studying in Belgium and working to support himself throughout his studies, to minimum subsistence allowance offered by the Belgian authorities. The CJEU held as follows:

$[U]$ nion citizenship is destined to be the fundamental status of nationals of the member states, enabling those who find themselves in the same situation to enjoy the same treatment in law irrespective of their nationality, subject to such exceptions as are expressly provided for. $^{3}$

In November 2014, the CJEU made a major decision on the rights to social protection for freemovers. In the landmark Dano case, ${ }^{4}$ CJEU has ruled that Union citizens lose the right to access to certain social protection packages if after the first 3 months they do not fall under the categories protected by the Citizenship Directive: workers (be them dependent or self-employed), former workers or jobseekers. Elisabeta Dano, a Romanian Roma and lone mother in charge of a 5-year-old with whom she resided in Germany since 2011. Ms Dano was living with her sister who also providing for her financially. At the time she made the new claim, Ms. Dano was already receiving two types welfare benefits in Germany - child benefit and lone parent benefit - and had applied for a third one, a special non-contributory cash benefit known as basic provision under the SGB II. It is for this third type of benefit that the Court decided that she was not entitled to claim it. The Court argued that Ms Dano was not eligible for this benefit because, at the time of claiming the benefits she was neither a worker, a former worker or jobseeker. The Court noted that "it is apparent from the documents before the Court that Ms Dano has been residing in Germany for more than three months [at the time of making the claim] that she is not seeking employment and that she did not enter Germany in order to work" (Paragraph 66).

In September 2015, the Court ruled a restrictive decision in another case on EU citizens' access to welfare rights. In Alimanovic, ${ }^{5}$ the decision confirmed that the

\footnotetext{
${ }^{1}$ Most notable from an extensive jurisprudence, Ritter- Coulais v Finanzamt Germersheim C-152/03, Case Sala v Freistaat Bayern C-85/96, Case Bindar v London Borough of Ealing C-209/03, Case Trojani v CPAS C-465/02, Case Ioannidis C-258/04.

${ }^{2}$ Case Rudy Grzelczyk v Centre public d'aide sociale d'Ottingnies-Louvain-la Neuve, C-184/99.

${ }^{3}$ Emphasis added. Case C-184 Grzelczyk ibid, Para 31.

${ }^{4}$ Case Elisabeta Dano and Florin Dano $v$ Sozialgeright Leipzig (Germany), C-333/13 http://curia. europa.eu/juris/document/document_print.jsf;jsessionid=9ea7d2dc30d5753e894d7fd2478683bfe 79 fccce5f4b.e34KaxiLc3qMb40Rch0SaxuObNf0?doclang=EN\&text=\&pageIndex $=0 \&$ part $=1 \&$ mode $=$ DOC $\&$ docid $=159442 \&$ occ $=$ first $\&$ dir $=\&$ cid $=312950$

${ }^{5}$ Case Alimanovic et al. $v$ Jobcenter Berlin Neukoeln (Germany) C-67/14 http://curia.europa.eu/ juris/document/document.jsf?text\&docid=167661\&pageIndex $=0 \&$ doclang=EN\&mode=req\&dir \&occ $=$ first \&part $=1 \&$ cid $=602229$
} 
member states can refuse social assistance to EU citizens who lose the status of Union workers. The Alimonovic family are Swedish citizens who resided in Berlin Germany. The family is composed by Nazifa the mother, Sonita elderly daughter and two minors still in the care of the mother: Valentina and Valentino. The family settled in Germany in early 1990s where the three children were born, but moved to Sweden in 1999. They returned to Germany in 2010. The mother and the older daughter worked on temporary contracts for nearly a year from June 2011 to May 2012 after which they applied for unemployment benefits. When these were exhausted, they applied for social assistance for people in long-term unemployment (known as Arbeitslosengeld II). The Court ruled that Germany can stop these payments because neither the mother nor the daughter have managed to retain their status of Union workers. The directive specifies that in order to retain the worker status, the EU citizens had to have worked for more than 1 year, laid off and registered with the relevant employment office. Even in this case, the Union worker can retain the status for only 6 months. Both the mother and the daughter exhauseted the 6 month period and therefore lost the status of Union worker.

Dano and Alimanovic cases are transformational for European freedom of movement beyond their legal consequences. Both rulings turn the light on the two elements of the freedom of movement that have been contested by the public and the far-right anti-immigration parties but which have slowly found their way on the agenda of mainstream political parties. The first is the fact that free movement might mean unconditioned freedom to settle and the fact that freedom of movement would be used by some Europeans to "shop" for more generous welfare benefits than those of their countries of origin. Dano and Alimanovic spoke directly to growing angst with free movement and addressed heads-on both concerns. The decision stated black over white that host member states can indeed deny non-contributory benefits to freemovers and that they enjoy relative generous rights that come with freedom of movement for a period of 3 months. After this period, freemovers can retain these rights if and only if they are workers, former workers, jobseekers or have enough financial resources to be economically self-sufficient. When freemovers do not hold such statuses, then they lose the rights established by the Directive. The Directive (Article 7.1) is clear on the right to reside after the first 3 months is conditioned by freemovers' financial self-sufficiency and "comprehensive sickness insurance" so that they or their family members do not become "a burden on the social assistance system in the host state". While the European freedom of movement creates ample mobility rights (Article 5 in the Directive) and a wide set of rights for the first 3 months of residence (Article 6), freemovers' need to meet the self-sufficiency criteria to retain these rights after the first 3 months (Article 7).

The asymmetry in rights between before and after the 3 months period had created public concern and confusion about freedom of movement and the Dano and Alimanovic doctrines have helped dispel them. In effect, these cases do nothing more than to switch the light and lay bare what seemed to be the best-kept secret on freedom of movement: its limits. While these limits have been part of the deal from the beginning, they have rarely entered the public debate on freedom of 
movement and they were consistently omitted from the promotion campaigns of the European Commission that pushed for more intra-European mobility and focused on the special rights of the freemovers. Perhaps more importantly is that before Dano and Alimanovic, the limits of freedom of movement seldom have been enforced. However, these recent decisions of the CJEU have received much media attention and announce a period of retrenchment of freedom of movement rights.

In the following section, I explore the policy and political responses to freedom of movement in times of crisis and zoom-in on their consequences for the migration of Southern Europeans.

\subsection{Freedom of Movement, No More? Political Contestation of Freedom of Movement in Times of Crisis and How It Affects Southern European en route to Northern Europe}

Since the start of the economic crisis of 2007/2008, political and public discourse increasingly challenge the freedom of movement of people within EU as an absolute right. Alarmed by the prospect of large inflows from the Central and Eastern European member states upon the end of the transition restrictions, numerous political leaders have spoken publicly on taking measures to 'control' migration from the other EU member states. The anticipation of the end of restrictions for Romanian and Bulgarian workers in January 2014 — while most European countries were facing their own internal economic crisis - triggered a wave of anti-immigration reactions in the EU as well as outside of it (see Barbulescu 2014).

In the spring of 2013, ministers of four member states - UK, Germany, Austria and the Netherlands-wrote a joint letter to the European Commission and Council [at that time under Irish Presidency] warning it of the fact that some cities in their countries were being put "under a considerable strain by certain immigrants from other member states" (Ministers of Interior of Austria, the Netherlands, UK and Germany 2013). The letter called for tougher controls for freemovers including efficient repatriations and re-entry bans: "[a]ll necessary measures need to be taken to deal with the consequences of this type of immigration and to fight its causes. This includes legal as well as financial measures." Interestingly, the member states refer to freedom of movement as "this type of immigration" and pleads for new "legal" measures to tackle it. The letter is important because it makes visible an emergent coalition of freedom of movement hardliners amongst the North-Western EU member states who, not accidently, have also been the main receivers of migration from the other member states. In response, a parallel coalition supporting freedom of movement emerged and brought the Scandinavian countries and the Central and Eastern European states together. The ministers of Sweden, Finland and Norway jumped in defence of freedom of movement in a joint letter set to the Financial Times (January 2014). The elections for the European Parliament in May 2014 
exported the heated debate on possible restrictions to freedom of movement rights to all member states.

What seemed a pro-mobility coalition between the new member states and the Scandinavian states collapsed with the arrival of the so-called "refugee crisis" in the summer of 2015. Central and Eastern European countries have shown antagonistic attitudes towards the freedom of circulation of refugees and asylum seekers. Some of the new member states refuted EU quotas for refugees and sought to seal off their borders as a way of preventing asylum seekers to enter. In reply, European Council President Tusk rang the alarm: "Let there be no doubt, the future of Schengen is at stake and time is running out. The clock is ticking, we are under pressure, we need to act fast" (Tusk 2015). Ironically, by threatening to quit the principle of freedom of movement for refugees and asylum seekers, the new member states put under risk the mobility of EU citizens including that of Central and European citizens who have been the main protagonists of intra-European mobility over the last decade.

Nonetheless, the strongest contestation of freedom of movement for EU citizens comes from the Northern European countries. For instance in the UK, in anticipation of the elections for the European Parliament as well as general elections, David Cameron declared that 'free movement in EU needs to be less free' (EUActive 2013) (for a full discussion on the UK, see Chap. 10, this volume). The Dutch Socialist Deputy Prime Minister, Lodewijck Asscher, used the colour codes used to announce weather calamities and called for 'orange alert' in anticipation of EU labour migration (EUObserver 2013). The Commission replied arguing that the member states raised concerns about welfare tourism including abuses but have not submitted evidence to support its existence. Instead, the Commission replied by taking a technical fact-checking approach and commissioned an independent study (ICF GHK 2013) which suggested a set of actions seeking to help the member states combat welfare tourism and make the most of freedom of movement (EC 2013). The GHK report (2013) found minuscule numbers of EU citizens who do not work, who are not economically active but who receive benefits from another EU member state. They represented less than $1 \%$ of all such beneficiaries (of EU nationals) in six countries studied (Austria, Bulgaria, Estonia, Greece, Malta and Portugal) and between $1 \%$ and $5 \%$ in five other countries (Germany, Finland, France, The Netherlands and Sweden). Data obtained by The Guardian on unemployment benefits found that a similar number of EU citizens receive them as Brits in other EU countries (19 January 2015).

Calls for more control on freedom of movement is not new. Previous episodes in which freedom of movement has been contested were of lower intensity and, more importantly, they came from individual member states rather than a consolidated block of hardliners. Yet, I argue that they paved the way for the first serious challenge that freedom of movement faced since its introduction. For instance, the eviction of Roma effectively limited the rights of Roma EU citizens and led to their repatriation from Italy in 2008 and France in 2010 - a practice that continues to the present day. Freedom of movement was challenged also from the left for it 
depreciated workers' rights and conditions by excluding posted workers from other European states to have the same protections local workers had. A series of rulings from the CJEU confirmed the right of companies to contract posted workers under the same conditions as workers in their countries of origin rather than workers in the countries were they are employed. ${ }^{6}$

The fact that member states' initiatives and statements challenging freedom of movement remained largely unsanctioned from the Commission but were rewarded by the public had the unexpected effect of "normalising" the contestation. From this point onwards, it was only a matter of time before a coalition of member states would write to the Commission asking for new measures to better control the mobility from the other member states.

In the context of the economic crisis and enlargement fatigue in the Northern Europe, individual member states have introduced new policy measures that de facto contract freedom of movement rights. UK and Germany have made changes that restrict access to social rights while Belgium has intensified the number of expulsions for EU citizens (see Chaps. 7, 9, and 10 in this book). The UK initially entertained the idea of quotas for migration from the other member states as it would help the Conservative Party meet its campaign pledge: to cap net migration including migration from EU to less than 100,000. However, the German Chancellor Angela Merkel convinced David Cameron to retreat from setting a cap on EU migration (The Guardian 2014). Cameron also consulted with European Commission chief Jean-Claude Juncker before delivering the Staffordshire speech in which he announced the new measures. In Brussels, a European Commission spokesman reacted to the plan set by Cameron by saying that it was up to "national lawmakers to fight against abuses of the system and EU law allows for this."

The recent talks about restrictions on freedom of movement also made their way in the European Parliament. A Spanish MEP, representing the newly established left wing party Podemos inquired the Commission about the effects the recent policies announced by the Northern European states on the rights of Spaniards. Pablo Iglesias filled a written question for the Commission asking about the particular situation of Spanish citizens in Germany who according to a draft law provides for penalties of up to 3 years imprisonment for people in breach of the country's residence conditions. The Commission responded reaffirming that it would check whether the draft is compatible with EU law (EP Written Answers 2014). In addition, Switzerland who is an associated state has voted in February 2014 in a public referendum to limit freedom of movement by submitting the new arrivals to quotas. The European Commission has already declined Switzerland's proposal to implement the quotas for migration from the other member states and presented the broad association agreement as one package that cannot be renegotiated separately.

${ }^{6}$ Case Laval Un Partneri Ltd v Svenska Byggnadsarbetareförbundet [2008] IRLR 160 C-341/05 and Case International Transport Workers Federation v Viking Line ABP [2008] IRLR 143 C-438/05. 
It is important to mention here that the politicisation of freedom of movement is not restricted to Northern Europe, but a similar process occurs in Southern Europe especially in Italy and Spain where Romanians and Bulgarians have tended to migrate. However, in Southern Europe politicisation intensified before and after the Eastward enlargements rather than at the time the transitional restrictions were lifted (Barbulescu 2013).

The once isolated challenges are slowing building into a consensus amongst the North-Western European states. The fact that the freedom of movement and not European citizenship is the target of contention shows that people have not appropriated the later in the same way as the former. Nonetheless, the emerging consensus focuses on a freedom of movement with more safeguards for the receiving states. Ultimately, this new focus translates into the following dilemma: how can member states organise the migration of wanted migrants while keeping out the unwanted migrants. This dilemma is precisely the one that states, including those who lead the contestation on freedom of movement, face when seeking to control migration from outside the EU. Because policies on freedom of movement and international migration seek to achieve what is increasingly the same result, they are becoming more alike at the policy level.

The concern of political elites about migration were not new as they followed the Eastward EU enlargement in 2004, 2007 and 2013. The economic crisis that started in 2007 has only aggravated this concern. It is important to mention here that public opinion and political leaders do not systematically target Southern Europeans in particular. Often, the raising numbers of Southern Europeans arriving in the North European countries since the start of the crisis have had little or no impact on the public opinion in the countries of destination and seldom featured in the media. An exception to this has economic liberal outlet, The Economist that has published from a series of columns profiling it: "They are coming: Hope for a better life is pushing young Europeans abroad" (13 September 2013) and "PIGS can fly: Some European economic migrants are more welcome than others" (16 November 2013). From the point of view of migration scholarship, one of the puzzle is the invisibility of the new Southern European migration. In sharp contrast, in the countries of origin in Southern Europe, the new emigration has moved to the top of the public agenda inciting talks about a veritable "brain drain" and "exile" migration of the young professionals.

While Eastern Europeans and Roma in particular are the poster child for limiting freedom of movement, changes in this policy area such as the ones announced by the Dano decision equally affect the Southern Europeans who are moving in times of crisis. More dramatic is that the rights as freemovers are called into question at a moment when Southern Europeans most need them to deal with the effects of the crisis. The impact on the ongoing contraction of freedom of movement rights is set to be higher for Southern Europeans. Unlike Central and Eastern Europeans, the young Spaniards, Italians, Portuguese or Greeks moving now to North-Western Europe have have grown up in a Europe in which mobility is free and is a defining feature of being in the EU. 


\subsection{Conclusions}

Southern Europeans have been the pioneers of European freedom of movement establishing migratory routes connecting the South with the North of Europe in the postwar period. However, when these routes were initiated, Southern Europeans were mere international migrants recruited by the Northern European countries largely through guest worker schemes. The exception to this rule was Italy, which was a founding member of the EU. With time, European Union has expanded and together with it, European freedom of movement has strengthened and expanded to incorporate new rights. With the accession of Spain, Greece and Portugal to the EU, the migratory route lost its significance only to re-emerge in the context of the economic crisis.

However, this new migration of Southern Europeans comes at a time when freedom of movement is challenged in a number of member states. A coalition of member states bringing together the UK, Germany, the Netherlands and, Austria — who share a hard line agenda on freedom of movement - have already taken action by introducing restrictive policies seeking to reduce access to social benefits, to effectively expel homeless EU citizens and to extend the re-entry bans for offenders. We, therefore, observe a hollowing out of freedom of movement rights, as political consensus builds up to limit rights associated with freedom of movement and in doing so, making it increasingly similar to international migration. While the contraction of freedom of movement rights and their systematic challenge have been triggered by the 2004, 2007 and, 2013 Eastward enlargements, Southern Europeans who chose to move to another member state since the start of the crisis will be equally affected by the ongoing changes. Brought up in the Europe in which freedom of movement was beyond doubt and even promoted by the member states and EU institutions, Southern Europeans see their rights endangered when they need them the most: to escape the financial and austerity crisis in their countries. Freedom of movement or the euro, once emblematic achievements of European integration are being tested under the shock conditions of the most severe crisis in living history. The EU institutions still seem determined to paint freedom of movement in terms of win-win situation benefiting sending and receiving member states alike. At the national level, however, the narratives on international migration and freedom of movement are becoming increasingly similar. 


\section{References}

Amersfoort, H., et al. (1984). International migration, the economic crisis and the state: An analysis of the Mediterranean migration to Western Europe. Ethnic and Racial Studies, 7(2), 238-268.

Barbulescu, R. (2012). Mobile union citizens should have portable voting rights. In R. Bauböck et al. (Eds.), Should EU citizens living in other member states vote there in national elections? (Working Paper No. 32/2012), Robert Schuman for Advanced Studies, EUDO Citizenship Observatory.

Barbulescu, R. (2013). The politics of immigrant integration in post-enlargement Europe: Migrants, co-ethnics and European citizens in Italy and Spain. PhD thesis in Department of Social and Political Sciences, European University Florence, Florence.

Barbulescu, R. (2014). EU freedom of movement is coming under increasing pressure in the UK and other European states. LSE European Politics and Policy Blog. http://blogs.lse.ac.uk/ europpblog/2014/02/20/eu-freedom-of-movement-is-coming-under-increasing-pressure-inthe-uk-and-other-european-states/. Accessed 15 July 2015.

Bauböck, R. (2007). Why European citizenship? Normative approaches to supranational union. Theoretical Inquiries in Law, 8(2), 453-488.

Bauböck, R. et al., (Eds.). (2012). Should EU citizens living in other member states vote there in national elections? (Working Paper No. 32/2012), Robert Schuman for Advanced Studies, EUDO Citizenship Observatory.

Bellamy, R., \& Warleigh, A. (2005). The puzzle of the EU citizenship. In R. Bellamy \& A. Warleigh (Eds.), Citizenship and governance in the European Union (pp. 3-19). London: Continuum International Publishing Group.

Castles, S. (1986). The guest-worker in Western Europe - An obituary. International Migration Review, 20, 761-778. doi:10.2307/2545735.

Castles, S. (2005). Nation and empire: Hierarchies of citizenship in the new global order. International Politics, 2(2), 203-224. doi:10.1057/palgrave.ip.8800107.

Castles, S., \& Kosack, G. (1973). Immigrant workers and class structure in Western Europe. New York: Oxford University Press.

Dustmann, C., et al. (2003). The impact of European enlargement on migration flows. London: Home Office.

EC (2013). Free movement of EU citizens and their families: Five actions to make a difference, $(\operatorname{COM}(2013) 837$ final of 25.11.2013.

Editorial Comments. (2014). The free movement of persons in the European union: Salvaging the dream while explaining the nightmare. Common Market Law Review, 41, 729-740.

Entzinger, H. B. (1978). Return migration from West European to Mediterranean countries WP 23. Geneva: ILO.

EU Observer. (2013, August 19). Dutch call for "code orange" on EU labour migration.

EUActive. (2013, November 27). Cameron: 'Free movement in EU needs to be less free'.

European Parliament. (2014). Written questions. 30 October 2014. http://www.europarl.europa.eu/ sides/getAllAnswers.do?reference=P-2014-007323\&language=EN. Accessed 20 Jan 2015.

Favell, A. (2008). Eurostars and Eurocities. Oxford: Blackwell.

Favell, A. (2014). The fourth freedom. Theories of migration and mobility in 'neo-liberal' Europe. European Journal of Social Theory, 17(3), 275-289.

Financial Times. (2014, January 16). In times of crisis, we must safeguard free movement. Letter from the EU Affairs Ministers of Sweden, Finland and Norway.

Hammar, T. (Ed.). (1985). European immigration policy: A comparative study. Cambridge: Cambridge University Press.

Hasen, P., \& Jonsson, S. (2014). Euroafrica: The untold history of European integration and colonialism. London: Bloomsbury Academic.

Henley and Partners. (2013). Visa restrictions index. 
ICF GHK. (2013). A fact-finding analysis on the impact on the Member States' social security systems of the entitlements of non-active intra-European migrants to special non-contributory cash benefits and healthcare granted on the basis of residence. Study conducted by ICF GHK in association with Milieu Ltd for DG Employment, Social Affairs and Inclusion 2013. http:// ec.europa.eu/social/main.jsp?langId=en\&catId=89\&newsId=1980\&furtherNews=yes

Joppke, C. (2010). Citizenship and immigration. Cambridge: Polity.

Kay, D., \& Miles, R. (1988). Refugees or migrant workers? The case of European Volunteer Workers in Britain (1946-1951). Journal of Refugee Studies, 1(3-4), 214-236.

Kostakoloupou, D. (2007). European Union citizenship: Writing the future. European Law Journal, 13, 623-646.

Maas, W. (2007). Creating European citizens. Lanham: Rowman \& Littlefield.

Maas, W. (2008). Migrants, states and the citizenship's unfulfilled promise. Citizenship Studies, 12(6), 583-596. doi:10.1080/13621020802450668.

Messina, A. (2007). The logics and politics of post-WWII migration to Western Europe. New York: Cambridge University Press.

Ministers of the Interior of Austria, Germany, the Netherlands and the UK. (2013, April). Letter to the Irish Presidency. http://docs.dpaq.de/3604-130415_letter_to_presidency_final_1_2.pdf. Accessed 20 Jan 2015.

Moravcsik, A. (1998). The choice for Europe. Ithaca: Cornell University Press.

Olsen, E. (2008). Transnational European citizenship: Tracing concepts in the European Integration Process. PhD thesis, Department of Social and Political Sciences: European University Florence, Florence.

Penninx, R. (1986). International migration in Western Europe since 1973: Developments, mechanisms and controls. International Migration Review, 20, 951-972. doi:10.2307/2545744.

Piore, M. J. (1979). Birds of passage: Migrant labour and industrial societies. Cambridge: Cambridge University Press.

Rath, J., \& Sagar, S. (1992). Ethnicity as a political tool in Britain and the Netherlands. In A. Messina et al. (Eds.), Ethnic and racial minorities in advanced democracies (pp. 201-224). New York: Greenwood Press.

Recchi, E., \& Favell, A. (Eds.). (2009). Pioneers of European integration. Cheltenham: Edward Elgar.

Romero, F. (1993). Migration as an issue in European interdependence and integration: The case of Italy. In A. S. Milward et al. (Eds.), The frontier of National Sovereignty: History and theory 1945-1992 (pp. 33-57). London: Routledge.

Schmitter Heisler, B. (1992). Migration to advanced industrial democracies: Socioeconomic and political factors in the making of minorities in the federal republic of Germany (1955-1988'). In A. Messina et al. (Eds.), Ethnic and racial minorities in advanced democracies (pp. 33-49). New York: Greenwood Press.

Shaw, J. (2007). The transformation of citizenship in the European Union: Electoral rights and the restructuring of political space. Cambridge: Cambridge University Press.

Shuibhne, N., \& Shaw, J. (2014). General report. In U. Neergaard, C. Jacqueson, and N. HolstChristensen (Eds.), Union citizenship: Development, impact and challenges. The XXVI FIDE Congress, Copenhagen.

Straubhaar, T. (1984). The accession of Spain and Portugal to the EC from the aspect of free movement of labour in an enlarged common labour market. International Migration, 22(2), 228238. doi:10.1111/j.1468-2435.1984.tb00999.x.

The Economist. (2013a, September 13). They are coming: Hope for a better life is pushing young Europeans abroad. http://www.economist.com/news/europe/21586606-hope-better-lifepushing-young-europeans-abroad-they-are-coming. Accessed 17 Jan 2015. 
The Economist. (2013b, November 16). PIGS can fly: Some European economic migrants are more welcome than others. http://www.economist.com/news/britain/21589879-someeuropean-economic-migrants-are-more-welcome-others-pigs-can-fly. Accessd 17 Jan 2015.

The Guardian. (2014, November 28). Angela Merkel forces David Cameron to retreat from EU migration cap.

The Guardian. (2015, 19 January 2015). Thousands of Britons on benefits across EU.

Tusk, D. (2015, 12 November 2015). Press remarks by President Donald Tusk after the informal meetings of EU heads of state or government. http://www.consilium.europa.eu/press-releasespdf/2015/11/40802205010_en_635829513000000000.pdf

Open Access This chapter is licensed under the terms of the Creative Commons AttributionNonCommercial 2.5 License (http://creativecommons.org/licenses/by-nc/2.5/), which permits any noncommercial use, sharing, adaptation, distribution and reproduction in any medium or format, as long as you give appropriate credit to the original author(s) and the source, provide a link to the Creative Commons license and indicate if changes were made.

The images or other third party material in this chapter are included in the chapter's Creative Commons license, unless indicated otherwise in a credit line to the material. If material is not included in the chapter's Creative Commons license and your intended use is not permitted by statutory regulation or exceeds the permitted use, you will need to obtain permission directly from the copyright holder.

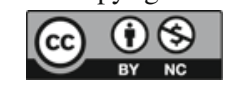




\title{
Chapter 3 \\ Immobility in Times of Crisis? The Case of Greece
}

\author{
Georgia Mavrodi and Michalis Moutselos
}

Greece, like other countries of Southern Europe, had in the beginning of the twentyfirst century completed a spectacular reversal of its migration history. Starting out as the European country with the most extensive emigration flows relative to its population in the early 1970s, Greece ended up, by the late 2000s, as the EU country with the highest percentage of (legal and estimated illegal) immigrant to national population (Kasimis 2013). Yet the severe economic crisis that started in 2008 challenges this remarkable development. Could the swing of the historical pendulum once again have more people migrating out of the country? Indeed the country's economic woes have reversed the balance of migratory flows. Repatriation of immigrants who resided in Greece has been much more dramatic than new emigration, the latter consisting mostly of high-skilled workers. Greek policymakers have so far not developed a coherent policy vis-à-vis these developments, while existing networks and institutional frameworks, many of which are a legacy of the post-war migration, have not adapted to the recent waves.

\subsection{Socio-economic Situation in Greece}

Greece is, without doubt, the Eurozone member-state hit most severely by the economic crisis. The country's economy was in recession between 2008 and late 2014 . Its real GDP growth rate fell dramatically during four consecutive years (20082011) peaking at a spectacular if devastating 7.1\% drop in 2011. In the year 2013 real GDP growth continued to fall by $3.9 \%$ (Eurostat 2014). Overall, almost $25 \%$

\author{
G. Mavrodi $(\square)$ \\ European University Institute, Florence, Italy \\ e-mail: georgia.mavrodi@eui.edu \\ M. Moutselos \\ Princeton University, Princeton, NJ, USA
}


Table 3.1 Real GDP growth rate and GDP per capita in PPS, 2007-2014

\begin{tabular}{l|l|l|l|l|l|l|l|l}
\hline & 2007 & 2008 & 2009 & 2010 & 2011 & 2012 & 2013 & 2014 \\
\hline Real GDP growth rate & $3.5 \%$ & $-0.2 \%$ & $-3.1 \%$ & $-4.9 \%$ & $-7.1 \%$ & $-7.0 \%$ & $-3.9 \%$ & $0.8 \%$ \\
\hline $\begin{array}{l}\text { GDP/capita in PPS (EU28 } \\
=100 \text { ) }\end{array}$ & 91 & 93 & 94 & 87 & 77 & 74 & 73 & 72 \\
\hline
\end{tabular}

Source: Eurostat $(2015 \mathrm{a}, \mathrm{b})$

losses of its GDP between and relative per capita income occurred between 2009 and 2013 (Table 3.1).

At the same time there is a decline in the population residing in the country. After years of a continuous population rise, owing much to international immigration, on 1 January 2009 the country had reached a peak at 11,190,654 inhabitants. Two years later they were reduced to $11,123,392$. It is estimated that the total population had fallen below eleven million as of 1 January 2014 (10,926,807 inhabitants), at about the same level as in the late 1990s, with another 100,000 estimated to have left the country by January 2015 (Eurostat 2015c).

Heavy recession has gone hand-in-hand with steady, uninterrupted increase in unemployment rates that began in early 2009. At that time, the number of long-term unemployed (defined as those actively seeking employment for 12 consecutive months or longer) surpassed 300,000 people, reaching 381,642 in December 2009, 474,745 in September 2010, and 611,785 in March 2011. Short-term unemployment also increased considerably, from 138,284 people in March 2010 to 180,817 people a year later albeit recording lower numbers during the summer months. During the first trimester of 2014, over 1,355,000 people were officially recorded as unemployed among a total population of approximately 11 million, with a slight decrease noted in the first trimester of 2015 (ELSTAT 2014, 2015).

How unemployment relates to the economic crisis can be traced by taking into account the official unemployment data recorded during the first trimester of each year since 1998. We choose to look at the first trimester (January-March) of each year to account for seasonal unemployment in important economic sectors such as tourism, agriculture, and constructions.

According to Greek official statistics, unemployment rose from $9.3 \%$ in 2009 to $27.8 \%$ in 2014 (ELSTAT 2009, 2010, 2011, 2012, 2014, 2015). It would be misleading to simply attribute high unemployment rates in 2009 to the outbreak of the economic crisis. During the previous decade, with the exception of 2007 and 2008, unemployment had been relatively high and, despite economic growth, unemployment rates had peaked in the first trimesters of 1999 and 2000 at $12.2 \%$ and $12.3 \%$, respectively. However, the first 2 years of crisis put a halt to the gradual but significant reduction of unemployment achieved between 2004 and 2008 (from $11.3 \%$ to $8.2 \%$ during the first trimester of those years, respectively) and introduce a period of unprecedented and precipitous rise ever since (ELSTAT 2009, 2010) (Table 3.2).

Apart from the loss of hundreds of thousands of jobs, the crisis has altered the geographical distribution of unemployment and strategies of job-seekers. For instance, those without a job today are much less selective than their counterparts 


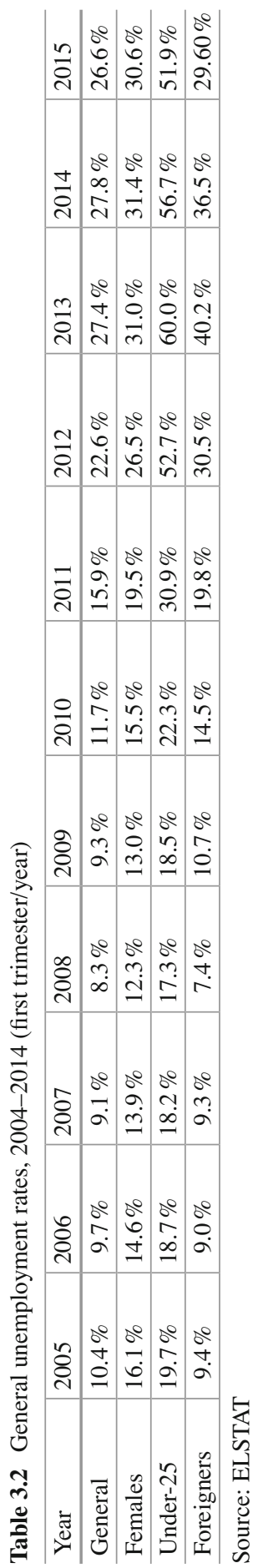


5 years ago: whereas $11.1 \%$ of the unemployed in early 2009 had refused at least one job offer for various reasons, those in early 2014 who did the same were only $4 \%$ (Ibid.). The share of part-time work in overall employment has also increased gradually, from $6.1 \%$ in early 2009 to $9.5 \%$ in early 2015 . More significant are the changes in qualitative characteristics of employment. In early $2015,68 \%$ of parttime employees had this type of employment because they could not find a full-time job, as opposed to $45.9 \% 6$ years before. Moreover, in addition to geographical areas known for high unemployment rates prior to the crisis (such as western Macedonia in Northern Greece), regions that previously attracted internal and international migrants for employment purposes (such as Attica and Crete) are now hit particularly hard (Table 3.3).

Within this wider framework of change some structural characteristics of unemployment in Greece have remained constant. Unemployment continues to affect predominantly the young, women and the low-skilled. Women aged 24 and below have most difficulties to find a job (in the last 3 years, over $55 \%$ of this category have been unemployed) while men with a degree of tertiary education have been the most likely to be employed. Paradoxically, those with primary education had and still have better chances in the Greek labour market than those with secondary education or the holders of a degree of tertiary technical education (ELSTAT 2009, 2010, 2012, 2013a, b, 2014, 2015). Last but not least, as Table 3.2 suggests, the crisis disproportionately affected foreign workers, a group that had exhibited lower unemployment rates than the national average, but whose unemployment level increased more than fivefold between 2008 and 2013.

The recession also resulted in the significant reduction of disposable income for individuals and households, increasing poverty, and social exclusion. According to Eurostat, the median net income declined from 11,963 euros in 2010 to 7714 euros in 2014 while the mean net income decreased from 13,974 euros to 8879 euros during the same period $(-35.5 \%$ and $-36,4 \%$, respectively) (Eurostat $2015 \mathrm{~d}$ ). According to more precise estimates covering part of this period, relative poverty (defined as the percentage of the general population with an income that lies below $60 \%$ of the median disposable income) showed a modest increase, from $19.4 \%$ in 2009 to $22.3 \%$ in 2013 (Matsaganis and Leventi 2013: 3). However, there is great variation among different population categories.

Table 3.3 Unemployment in selected Greek regions, 2009-2014 (first trimester)

\begin{tabular}{|c|c|c|c|c|c|c|c|}
\hline \multirow[b]{2}{*}{ Region } & \multicolumn{7}{|l|}{ Year } \\
\hline & 2009 & 2010 & 2011 & 2012 & 2013 & 2014 & 2015 \\
\hline Attica & $7.6 \%$ & $10.7 \%$ & $14.7 \%$ & $22.9 \%$ & $28.6 \%$ & $28 \%$ & $26.7 \%$ \\
\hline Crete & $10.9 \%$ & $12.9 \%$ & $15.7 \%$ & $23.4 \%$ & $26.9 \%$ & $26.9 \%$ & $27.2 \%$ \\
\hline Western Macedonia & $14.4 \%$ & $15.1 \%$ & $22.3 \%$ & $28.5 \%$ & $32.0 \%$ & $28.4 \%$ & $29 \%$ \\
\hline Ionian islands & $14.1 \%$ & $20.4 \%$ & $20.3 \%$ & $15.9 \%$ & $22.8 \%$ & $27.4 \%$ & $28.9 \%$ \\
\hline Southern Aegean & $16.9 \%$ & $18.9 \%$ & $24.3 \%$ & $13.9 \%$ & $24.9 \%$ & $30.3 \%$ & $25.4 \%$ \\
\hline
\end{tabular}

Source: ELSTAT (2009, 2011, 2012, 2014, 2015) 
Between 2009 and 2013, relative poverty increased most sharply for the unemployed (from 34.2 to $46.7 \%$ ), for households residing in rented property or paying home mortgage (from 19.3 to $27.2 \%$ ), for the self-employed (from 17.3 to $24.0 \%$ ), and for those residing in Athens, as opposed to other urban or rural areas (from 16.1 to $24.7 \%$ ) (Matsaganis and Leventi 2013: 3). Moreover, over 60\% of the unemployed adults were in danger of social exclusion in 2010, 2011 and 2012 (Karakitsios 2014: 10). In contrast, relative poverty has been negligible for civil servants and bank employees; it has been low and declining for some professional groups (private doctors, lawyers, engineers and mass media employees); it has slightly increased for paid employees in the private sector and students (1.5 and $3.2 \%$ increase, respectively); and, albeit high, it showed a sharp decrease for those employed in agriculture (from $34.1 \%$ in 2009 to $24 \%$ in 2013). Finally, among generational categories, young adults up to 29 years have been subject to the sharpest increase in relative poverty (from $19.5 \%$ in 2009 to $26.9 \%$ in 2013 ), the reverse of pensioners and the elderly (Matsaganis and Leventi 2013: Ibid.).

These estimates reveal a mixed picture. While the Greek recession has been continuous and severe, parts of the population have remained more protected (civil servants who have retained their positions albeit with reduced salaries, free professionals and, to a significant degree, pensioners) while others (such as the unemployed, the young and the self-employed) have experienced growing relative deprivation and/or poverty. Even when income in 2013 is compared with a stable poverty limit, namely the adjusted poverty level of the year 2009, the unemployed, the self-employed and the young appear as the main victims of the crisis (Matsaganis and Leventi 2013: 4-5). These developments relate to long-established structural characteristics and redistributive consequences of the Greek system of social protection, along with the effects of austerity on public finances and programs of social security (Matsaganis 2013: 2).

The latter continued to protect the rights and income of parts of the population directly or indirectly supported by the state (civil servants, employees in public utility companies and pensioners) much more than the unemployed, the paid employees in the private sector, and the self-employed. For decades, this social welfare model - at the same time discriminatory, selective and weak - was coupled by the protective and supportive role of traditional social networks (most importantly the family) towards the young, the elderly and those in need, characterised by the provision of both material and non-material support to the most vulnerable (Htouris 2012; see also Eurostat 2013a for data on income pooling and sharing within the household). Increasing unemployment and cuts in earnings and wages have put strains on the ability of households and families to fully perform this function.

The recession has most severely hit parts of the population with low levels of human capital (Zografakis and Mitrakos 2012). The latter include single-parent families, the long-term unemployed, and the country's immigrant population, especially third-country nationals (largely employed in the private sector and in lowpaid seasonal economic activities) who have largely remained outside the coverage of the basic social security net (Matsaganis 2013; Zografakis and Mitrakos 2012; Balourdos 2012). It has been estimated that Albanian immigrant households have 
faced the greatest danger of falling to low-income-earner status, compared to both Greek households and immigrant households of other nationalities (Zografakis and Mitrakos 2012). The less favourable employment situation for third-country nationals is not a Greek phenomenon and has been noted in labour markets across the EU. In particular, along with the existence of looser ties with the host country, the employment of third-country nationals in jobs with fixed-term contracts and in economic sectors with high sensitivity to the business cycle (such as tourism and construction) is connected with higher labour mobility and employment volatility.

\subsection{Migratory Dynamics and Volume of Emigration Flows}

The period between 1955 and 1977 marked the most extensive wave of outward migration, with about 1.2 million people moving out of Greece, roughly half to Germany, 30,000 to Belgium and about 370,000 overseas, mostly in the United States, Canada and Australia. The reasons for emigration were primarily economic and the rural areas of Epirus, Macedonia and Thrace in the North were particularly overrepresented during the post-war wave. In addition, about 65,000 political refugees had fled the country after the Greek Civil War after 1949, but the majority of them relocated to countries of the former Eastern Bloc. After 1970 there was a counter-wave of repatriation, particularly from European countries, towards Greek urban centers (Glytsos and Katseli 2005).

It is notable that data for post-war emigration are more informative than currently available data collected by the Greek authorities. The scarcity of detailed information poses a major challenge to the description, analysis and understanding of the phenomenon - a problem not limited to the Greek case, as the difficulty in collecting systematic data partly relates to the free movement of people among EU member-states (Deutsche Bank Research 2011: 5).

The Greek national statistical agency (ELSTAT) focuses on recording the number of foreign nationals entering or residing in the country. Additional estimates of emigration flows and their publication, a practice that began in 2010, do not include Greek citizens. Moreover, the issue of current migration movements from Southern EU member-states to the rest of the EU is under-researched, fuelled by nonregistration of recent emigrants with the authorities of their countries of origin (Triandafyllidou and Gropas 2014). As a result, best available data are those released by national statistical agencies in the countries of destination, as well as larger databases and publications by international organisations.

According to Eurostat (2013b), outflows from Greece began outnumbering inflows in 2008, when Greece recorded negative net migration for the first time since 1998 (the first year of publication of such data). Between 2009 and 2012, emigration increased rapidly. Outflows peaked in 2010 followed by a drop in 2011, only to resume strength in 2012. The timing of the increase in net migration outflows corresponds to the outbreak of the economic crisis. The figures also include foreign citizens, including non-EU citizens, who had settled in Greece in the 1990s 
and 2000s. Indeed, most recent work on emigration from Italy highlights the exodus of EU citizens and third-country nationals (Triandafyllidou and Gropas 2014: 2).

According to the OECD, the number of registered foreign (non-EU) citizens in Greece fell from 610,800 in 2009 to 507,000 in 2012 (OECD 2015). This development may reflect a large-scale departure of Albanian nationals, who had been the dominant immigrant group in Greece since the early 1990s. In fact, according to the estimates of the Albanian Institute of Statistics about 95,000 Albanians of 18 years old and above returned from Greece to Albania between 2009 and 2013 (INSTAT and IOM 2014). In contrast, emigration of Greek nationals appears to be limited (OECD 2013: 258). This is not to say that Greeks are not part of the wider phenomenon of new migrations from the European South to Northern Europe and beyond. According to the OECD, significant percentage increases in new arrivals of Greek citizens have been recorded in Germany, the United Kingdom, the Netherlands and Sweden. Over 30,000 people left Greece for these countries in 2011 while in 2012 there were over 40,000 Greek nationals arriving in Germany and Sweden alone (OECD 2013: 256, 258).

National statistics, when available in the countries of destination, offer a more detailed picture. A direct comparison among them is often difficult, given the different time frames and categories used (citizenship, country of birth, point of departure) The most recent provisional immigration data from Germany indicates that 31,861 persons arrived from Greece in 2014, 30,602 of whom were non-German citizens. These figures made Greece the 11th most important country of origin of new immigrants, despite a slight decrease when compared to previous years (a total of 35,811 persons in 2012 and 34,728 persons in 2013). At the same time, a total of 17,225 persons emigrated from Germany to Greece (Statistisches Bundesamt 2014).

A clearer picture is provided by data reflecting the immigration trend of nonGerman citizens from Greece in the last decade. After 5 years of stability (between 8000 and 9000 persons each year in the period 2005-2009, greatly outnumbered by an average of 15,000 non-German citizens emigrating from Germany to Greece per year, new arrivals increased dramatically in 2011 (12,523 persons) and 2012 (23,779 persons), before peaking at 33,739 persons in 2013 and falling slightly to 30,602 persons in 2014. At the same time, it seems that the outbreak of the severe economic crisis discouraged Greeks already residing in Germany from returning back: compared to 14,841 non-German citizens who emigrated to Greece in 2009, 11,482 chose to do so in 2010, followed by 10,306 in 2011 (Statistisches Bundesamt 2014: 19-20). Yet, a modest increase in the number of those leaving to Greece since 2012 may indicate a reversal of this trend, possibly related to the stabilisation of the economic situation in Greece or the limited return of retired past economic migrants.

The upward trend of arrivals from Greece can also be detected in the United Kingdom, at a faster pace, albeit at a smaller scale. According to annual estimates of the Office of National Statistics - reporting foreign-born and foreigners -, estimated arrivals of those born in Greece for the period 2006-2014 peaked in 2011 and 2012 (about 8000 new arrivals), slightly upwards from 6000 arrivals in 2007 and went back to 6000 in 2013 and 2014. These inflows are typical of the entire period since the early 2000s reflecting a strong preference among Greek youth for the UK 
as a place of study and employment. The most remarkable development is the slowdown of return migration from the UK to Greece that has caused the number of UK residents born in Greece to swell from about 25,000 in 2007 to about 52,000 in 2014. Similar trends can be found in the estimated numbers of Greek nationals residing in the UK with 54,000 residents in 2012 compared to 26,000 in 2007 (see also UK chapter) (Office of National Statistics 2015).

In the Netherlands, the total number of residents of Greek origin shows a steady and significant increase in the last 6 years (from 13,888 persons in 2009 to 15,052 in 2011 , to 18,253 in 2013 and 19,217 in 2014). Only 599 persons among them belong to the second generation whereas 4724 are newcomers (CBS 2014). Increases in arrivals of Greek citizens are also recorded in other member-states but they start from a very low base and the total number is rather insignificant. In Austria, for instance, the number of Greek citizens arriving in the country between 2010 and 2012 increased twofold: 519 persons in 2010, followed by 813 in 2011 and 1201 in 2012 (Statistik Austria 2013: 28). In Belgium, 14,922 Greek residents were recorded on January 1st, 2009 and 14,798 a year later, while the number increased to 16,275 by January 1st 2015 (Statistics Belgium 2009, 2010, 2015; see also Chap. 8 in this volume). New arrivals reached 715 people in 2010 and 1025 people in 2012 (Eurostat 2014). In Sweden, 517 immigrants born in Greece arrived in 2009, followed by 602 in 2010, 1018 in 2011, 1546 in 2012, 1519 in 2013 and 1243 in 2014). The number of Greek citizens arriving in Sweden during the same period was somewhat lower but displayed the same trends (483 in 2009, 520 in 2010, 929 in 2011, 1348 in 2012, 1378 in 2013, 1088 in 2014) (Statistiska Centralbyran 2015). Similar trends were also observed in France, where the number of foreigners of Greek citizenship resident in France (étrangers) increased from 5884 people in 2006 to 5962 in 2008 to 6596 in 2011 (INSEE 2006, 2008, 2011 - later data do not include Greeks as a separate category).

Finally, when it comes to western European destinations outside of the European Union, Switzerland also documents increases in the number of foreign-born Greek citizens present in the country in recent years. The inward migration of Greek citizens increased from 713 persons in 2009 to peak at 1685 incomers in 2013 with a decrease to 1464 persons in 2014 (Statistik Schweiz 2015).

On the basis of the data presented above, it becomes clear that Greek emigration to central and northern Europe is, generally, on the increase since 2008. However, the size and pace of the movement may differ greatly from one country of destination to another. When one compares the current flows to the post-war emigration from Greece to Western Europe, one is struck by aspects of continuity (Germany, Belgium and Sweden having been traditional destinations), and change (the UK and the Netherlands). In terms of size, the average gross annual emigration from Greece to Germany for the period is roughly equal to the numbers of current outflows (about 30,000 persons a year; see Fakiolas and King 1996). However, a direct comparison between the two periods is not easily warranted. For instance, it is reasonable to assume that the free movement of people inside the EU and the absence of state-sponsored, heavily monitored, intra-European migration - typical of the postwar period - underestimates the number of Greeks currently moving or residing 
abroad or engaging in seasonal and repeated migration. Free movement of capital and the common currency might also render difficult the measurement of remittances towards Greece from these recent migrants.

A second tentative conclusion is that the overall number of Greek emigrants does not correspond to a wave of mass emigration, despite the heavy recession and the favorable institutional framework of freedom of movement within the EU. In this regard, Greece does not differ from the other EU member-states that have been severely hit by the crisis. As noted recently, "if we consider the extent, the duration and the harshness of the crisis it seems that a surprisingly lower number of Greeks, Italians, Irish, Spaniards and Portuguese have emigrated than would have been expected" (Gropas and Triandafyllidou 2014a: 5).

There exist many explanations behind the discrepancy between predicted economic migration and observed reality. First, there are well-known impediments to labour mobility within the EU: inter alia, linguistic barriers, cultural differences, inadequate information on labour supply and demand in other EU member-states and incomplete recognition of qualifications (Deutsche Bank Research 2011). Mobility is also, generally, very costly for unskilled workers, who would have the greatest incentive to migrate, while skilled workers are able to cover such costs more easily but do not face as high unemployment levels (for a similar analysis, see SER 2001: 7-8). Htouris (2012) has also underlined the protective role of the Greek family for those hit by the economic crisis in the absence of other welfare provisions. We may assume that this family-based safety net, bolstered by the relative protection of pensions during the crisis, constrains the geographic mobility of young, unemployed Greeks.

An underdeveloped area of research relates to the qualitative characteristics of recent emigrants, such as their skills, professional aspirations, geographic origin, family history and networks etc. Empirical research on emigration is limited in the Greek scholarly community, since most academics and research institutions still focus on issues of immigration (including irregular immigration), settlement, and integration of third-country nationals. Two surveys have dealt exclusively with documenting the characteristics of emigration flows (Lambrianidis 2011; Gropas and Triandafyllidou 2014a, b). However, both concentrated on the movement of the high-skilled, while the older survey is based on data collected prior to the economic crisis.

There is practically no systematic data available on emigration flows of the lower-skilled or unskilled Greek emigration. Due to its seasonal and undocumented nature this type of emigration is also underestimated in official registries (unlike Portugal, there is no recording of posted workers, see Chap. 5 in this volume). This remains an empirical challenge for the full appreciation of the recent migration movement from the South. Indeed, a private communication of the authors with a representative of the Association of Immigrants and Coethnics from Germany, confirmed that many low-skilled workers migrate for a brief period and work in restaurants, construction and transportation (often in businesses owned by relatives or other co-ethnics) without registering residence or employment (telephone interview 10/08/2014). 
In reality, the only piece of empirical research that conveys parts of the bigger picture is the recent online survey by Gropas and Triandafyllidou (2014b). The survey collected responses from 919 Greek citizens who emigrated abroad between 2007 and 2013, the vast majority among them having left since 2009. Biases associated with snowball sampling and self-selection limit the generalizability of the study, but certain conclusions merit discussion. Of all respondents, $88 \%$ hold a higher education degree and $97 \%$ were up to 45 years of age (48\% were under 30 years old). Their five most popular destinations in the EU were the UK, Germany, the Netherlands, Belgium and Sweden, with Switzerland and Norway among the top-five destinations outside the EU (other countries included the United States, United Arab Emirates and Canada).

In the country of destination, most respondents found employment in the IT sector, education and research, medical and paramedical professions, hotel services and catering, and engineering. The wish to improve their academic and professional training, their sense of lacking a future in Greece, and the ability to find better professional opportunities were by far the three most important motivations for leaving abroad. Finally, the majority of their respondents $(58 \%)$ declared their wish to remain in their country of destination for more than 5 years or even migrate further to another country rather than return to Greece in the near future (Gropas and Triandafyllidou 2014b).

The survey dovetails Lambrianidis' findings (2011) based on data collected prior to the outbreak of the crisis, which shows that the phenomenon of Greek emigration of the high-skilled pre-dated the recession. The crisis has only intensified the phenomenon but not to the point of creating a "mass wave" of Greek emigration of professionals and scientists.

\subsection{Public Discourses and Policy Responses on New Migration}

As noted in the previous section, the historical experience of mass postwar emigration into Northern Europe was dominated by the image of the low-skilled male manual worker, typically from rural areas, who sent remittances to the family home, relied on state-led programs of employment and integration and was willing to repatriate once economic conditions were no longer propitious. This image was not entirely accurate, as later migrants in the postwar boom included families and older people, their duration of stay increased and they exploited migrant networks (Glytsos and Katseli 2005). However, the differences with current outflows cannot be overstated: the Greek state has not developed any systematic policy on sending migrants or attracting them back to Greece - the high-skilled exploit professional networks, while the low-skilled rely on family acquaintances. Elite discourse on migration has largely focused on the prospects of "brain drain" but has mostly been framed in terms of individual decision-making. 


\subsubsection{Discourse on New Migration}

The recent movement towards the European North has featured in Greek public discourse mainly in association with the prolonged economic crisis. Since the latter has resulted in acute political polarization, references to the migratory waves are often tinged with partisan interpretations. For instance, when reporting on the so called "neo-immigrants" (neometastates), the Left-leaning press emphasizes themes of appropriation of added value by Northern European employers and exploitation by fraudulent employment offices set up in countries of destination (Avgi 12/05/2013; Eleftherotipia 05/01/2014). On the other side of the political spectrum, the popular right-wing press has evoked romantic, organic images of "national bleeding" and lamented the forceful recruiting of young Greeks by Germany, reminiscent of the forceful recruitment of Jenissaries (paidomazoma) in Ottoman times (Dimokratia 06/09/2012, 04/07/2013). In both cases, the interpretative frames implicitly or explicitly assign responsibility to the choices of pro-austerity governments (often explicitly using terms such as "sell-outs", "traitors"); the same narratives often suggest a conscious and coordinated attempt of Northern European governments to draw the best talent from the South that goes unchallenged. Interestingly, the same reports draw abundantly from historical analogies (a typical one is "Gastarbeiter with a university degree").

Other newspapers, typically less critical of the bailout agreements with EU partners, are concerned with high-skilled migration and the prospect of "brain drain". They emphasize the benefits of migration for educated Greeks who cannot find adequate employment at home, but underline the paradox of aiming to rebuild an economy without its best-skilled workers. Reporting is otherwise full of informal interviews of Greek doctors, nurses and engineers who have moved abroad (To Vima 01/03/2013, Kathimerini 12/01/2013). Journalists often include data from the above-cited studies by Triandafyllidou, Groppa and Lambrianidis (and sometimes briefly interview the authors) to underline the high skills of migrants, as well as the continuities from pre-crisis migration. However, they underreport examples of seasonal, low-skilled migration, with scattered accounts of exploitative working conditions (Kathimerini 28/12/2014). Another notable underreported story in the Greek press is the remarkable outflow of third-country nationals, especially Albanians. An exception was the investigative hourly broadcast by journalist Stavros Theodorakis on Greek-born and raised teenagers who left Greece with their families.

Beyond the press, the new migratory waves are the object of discussions and debates among academics, journalists and political elites. This discussion has at times taken the form of academic roundtables -notably in collaboration with the Greek-German Cultural Society "Dialogos" in Thessaloniki or under the auspices of the Onassis Foundation in Athens- and has at times assumed a debate-style form of "Should I stay or should I go?". One of these debates, organized by Intelligence Squared Greece, featured famous Greek academics, writers and entrepreneurs. Generally, framing migration as a moral dilemma in times of national emergency is of limited consequence in the Greek public discourse, as most arguments are actually about the costs and benefits of the decision to migrate. 
Public discourse regarding outward migration is also notable for its silences. First, it is entirely disconnected from the very heated discussion on third-country nationals residing in Greece, notably immigrants/refugees and asylum seekers whose applications are processed by Greek authorities and who remain in quasilegal or illegal status. The most direct reference to the dangers of anti-immigrant sentiment in Greece backfiring against the Greek new immigrants abroad was made inside the Greek parliament by the Communist Party's MP, Georgios Marinos (Parliamentary Proceedings 15/03/2014). Second, the absence from the public debate of acting Greek associations and representatives of the Greek Orthodox Church in Northern Europe is notable. Time will show if these older organizations have not made public contributions, because arrivals have been very recent or because these particular ethnic associations, created in the 1960s and serving Greek guest workers and their families, represent an outdated form of community organization.

\subsubsection{Policy Initiatives for the New Migrants}

Historically, Greek policymakers have had an ambivalent attitude towards migration into Northern Europe, on the one hand regarding it as a safety valve and a source of income through remittances, and on the other hand bemoaning the skills and talent lost in the process. This was reflected in somewhat contradictory policies: Greek governments initially encouraged remittances and signed bilateral agreements for enhancing workers' assimilation through skills and language training; since the early 1970 s, however, they actively sought repatriation by providing incentives for asset purchases in Greece and reductions in duties and taxes for imported consumer durables (for instance, cars bought abroad). In another example of incoherent policy, the children of Greek migrants were offered the option to attend exclusively Greek schools, but were later encouraged to attend German schools or bilingual programs (Glytsos and Katseli 2005).

If the previous Northward migration wave was anchored to formalized interstate agreements, current movement takes place within a free-movement framework. Migratory trajectories of those leaving Greece are individually decided and executed and inter-state initiatives are of limited importance. For instance, the "Job of My Life" (Mobi-proEU) program, sponsored by the German Federal Ministry of Labor and aimed at training young workers from other EU countries, received very little attention in Greece, mostly because of limited cooperation between the program organizers and the Greek Manpower Employment Organizations-OAED (Greek Reporter 30/01/2014). Certain initiatives promoting partnerships at the municipal level under the auspices of the Greek-German Assembly have also had very limited success on employment and training. On the other hand, sector-specific information sessions and cooperative initiatives among academic institutions in Greece, businesses and professional associations, especially for doctors and 
engineers, were more successful and facilitated the resettlement of thousands of Greek professionals (Kathimerini 13/05/2012, APE-MPE 28/05/2014).

Inversely, there have been no specific laws passed by the Greek parliament or decisions by Greek governments since 2008 targeting recent migrants beyond the provisions of existing EU Treaties. Much like the Greek press, parliamentary debates around the "brain drain" have been subsumed under the pro- and anti- memorandum narratives. New migration is thus used as an off-handed reference in discussions about funding a new technology hub in Thessaloniki or passing the annual budget law (Parliamentary Proceedings 21/08/2013, 05/07/2012). Developments in two policy areas related to the new migrants reveal, if anything, a disengagement of the authorities. First, Parliament passed a law in late 2011 to gradually close or convert Greek-language schools abroad, stressing the need to integrate with hostcountry curriculum. In addition, there has been no progress on the issue of voting rights of Greek citizens residing abroad. Greece is indeed one of the very few European states not to have provisions for expatriates exercising their right to vote (Lafleur 2013) and that despite Constitutional provisions to that effect (Sitaropoulos and Giakoumopoulos v. Greece 2012).

The absence of an official policy towards recent migrants also reflects the absence of an institutionalized framework towards the Greek diaspora, in contrast with other Southern European countries, such as Italy or Portugal. The Council of Expatriate Greeks (Simvoulio Apodimou Ellinismou), founded in 1995 to consult the Greek government on issues pertaining to citizens abroad, had entered a period of decline long before the crisis had started and was virtually inactive by 2010. In fact, the only systematic policy initiative affecting new migrants was the obligation to register at a newfound tax division for Greek citizens living abroad, intended to avoid tax evasion.

\subsection{Conclusion}

Unsurprisingly, the serious economic problems Greece has faced in the last few years have increased migratory outflows and transformed it into a country of emigration - a position it had not assumed in decades. Although the bulk of outflows consist of third-country nationals returning to their home countries or moving to more promising destinations within the European Union, Greeks, especially the high-skilled, have also emigrated or postponed repatriation. They have chosen historically preferred destinations (with Germany assuming the lion's share), as well as more novel ones, such as the UK. However, this movement has not assumed the massive proportions of post-war migration, as the severity of the crisis might have suggested and the heavy -if rather superficial- politicization of the "brain drain" implied. On the other hand, existing migrant networks and institutionalized support by the Greek authorities have proven ill-suited, under-developed and under-utilized to face the needs of the new migrants, again in contrast with the more structured post-war migration. In fact, policy and opinion makers in Greece have mostly 
subsumed the importance and challenges of recent movements under domestic political divisions. It remains to be seen if concrete policy changes vis-à-vis recent migrants materialize, as Greece enters a post-crisis era.

\section{References}

Avgi. (2013, May 12). Gastarbaiter me Ptichio; (2014, January 22) Thimata Ekmetalleusis oi Ellines Neo-Metanastes.

Balourdos, D. (2012). 'I Ftohia stin Ellada: Taseis, prokliseis kai prooptikes' In: D. Balourdos \& M. Petraki (Ed.), Nea Ftoheia kai Koinonikos Apokleismos. Politikes Katapolemisis kai Kathierosi enos Elahistou Eggyimenou Eisodimatos (pp. 21-53), Special Meeting of the Permanent Committee on Social Affairs, 13th Period - 3rd Term, Athens: Hellenic Parliament.

CBS - Centraal Bureau voor de Statistik. (2014). Population: Dex, age, origin and generation. https://www.cbs.nl/. Accessed 28 Sept 2015.

Deutsche Bank Research. (2011). Labour mobility in the euro area. Reports on European integration EU monitor No. 85. Frankfurt am Main.

Dimokratia. (2012, September 6) Ethniki Aimorragia; 2013, July 4, To Germaniko Paidomazoma ston Exathliomeno Noto.

Eleftherotipia. (2014, January 5). I Ellada ksanapligoni ta paidia tis.

Elstat. (2009). Deltio Typou. Ereyna ergatikou dynamikou A' trimino 2009, Pireaus, 22 June 2009.

Elstat. (2010). Deltio Typou. Ereyna ergatikou dynamikou A' trimino 2010, Pireaus, 17 June 2010.

Elstat. (2011). Deltio Typou. Ereyna ergatikou dynamikou A' trimino 2011, Pireaus, 16 June 2011.

Elstat. (2012). Deltio Typou. Ereyna ergatikou dynamikou A' trimino 2012, Pireaus, 14 June 2012.

Elstat. (2013a). Unemployment, long-term and short-term unemployed. 8 October 2013.

Elstat. (2013b). Deltio Typou. Ereyna ergatikou dynamikou A' trimino 2013, Pireaus, 13 June 2013.

Elstat. (2014). Deltio Typou. Ereyna ergatikou dynamikou A' trimino 2014, Pireaus, 12 June 2014.

Elstat. (2015). Deltio Typou. Ereyna ergatikou dynamikou A' trimino 2015, Pireaus, 11 June 2015.

Eurostat. (2013a). Income pooling and equal sharing within the household - what can we learn from the 2010 EU-SILC module? Eurostat Methodologies and Working Papers.

Eurostat. (2013b). Crude rate of net migration plus adjustment. Accessed 7 July 2014.

Eurostat. (2014). Immigration by sex, age group and citizenship, Brussels, 20 June 2014. http:// epp.eurostat.ec.europa.eu. Accessed 10 July 2014.

Eurostat. (2015a). Real GDP growth rate - Volume. http://epp.eurostat.ec.europa.eu. Accessed 28 Sept 2015.

Eurostat. (2015b). GDP per capita in PPS. http://epp.eurostat.ec.europa.eu. Accessed 28 Sept 2015.

Eurostat. (2015c). Population on 1 January. http://epp.eurostat.ec.europa.eu. Accessed 28 Sept 2015.

Eurostat. (2015d). Mean and median income by age and sex. http://epp.eurostat.ec.europa.eu. Acccessed 28 Sept 2015.

Fakiolas, R., \& King, R. (1996). Emigration, return, immigration: A review and evaluation of Greece's postwar experience of international migration. International Journal of Population Geography, 2, 171-190.

Glytsos, N. P., \& Katseli, L. T. (2005). Greek migration: The two faces of Janus. In K. Zimmermann (Ed.), European migration: What do we know? (pp. 337-388). Oxford: Oxford University Press.

Greek Reporter. (2014, January 30). MobiPro-EU: The job of my life. 
Gropas, R., \& Triandafyllidou A. (2014a). Emigrating in times of crisis. Highlights and new data from an e-survey on high-skilled emigrants from southern Europe and Ireland. Survey Report, Global Governance Programme, European University Institute.

Gropas, R., \& Triandafyllidou, A. (2014b). Country focus: Emigration of Greek nationals during the crisis. Florence: European University Institute.

Htouris, S. (2012). Oi diastaseis tis Ftohias kai tou Koinonikou Apokleismou stin Elliniki Neolaia. Politikes gia ti metavasi apo tin ekpaideysi sthn apasholisi kai tin epaggelmatiki zoi, in Balourdos D. \& Petraki M. (Ed.), Nea Ftoheia kai Koinonikos Apokleismos. Politikes Katapolemisis kai Kathierosi enos Elahistou Eggyimenou Eisodimatos (pp. 85-97). Special Meeting of the Permanent Committee on Social Affairs, 13th Period - 3rd Term, Athens: Hellenic Parliament.

INSEE. (2006). Entragers selon le sexe, la categorie de population et la nationalite detaillee, Recensement de la population 2006, 2008, 2011 exploitation principale, MORE (full details).

INSTAT \& IMO. (2014). Return migration and integration in Albania 2013.

OECD International Migration Outlook. (2013). http://www.keepeek.com/Digital-AssetManagement/oecd/social-issues-migration-health/international-migration-outlook-2013 migr_outlook-2013-en. Accessed 5 July 2014.

OECD International Migration Outlook. (2015). http://www.keepeek.com/Digital-AssetManagement/oecd/social-issues-migration-health/international-migration-outlook-2015_ migr_outlook-2015-en. Accessed 28 Sept 2015.

Karakitsios, A. (2014). Ftohia ton ergazomenon stin Ellada: Diastaseis kai Politikes. Keimeno Politikis 23, July 2014. Athens: ELIAMEP.

Kasimis, C. (2013). Greece, migration 1830s to present. In E. Ness (Ed.), The Encyclopedia of global human migration. London: Blackwell Publishing.

Kathimerini. (2014, December 28). Thimata Ekmetallefsis i Neometanastes; (2013, January 12). Sti Germania 123,000 Ellines Metanastes; (2012, May 13) 6,000 Ellines Giatroi sti Germania.

Lafleur, J. M. (2013). Transnational politics and the state: The external voting rights of diasporas. Abingdon: Routledge.

Lambrianidis, L. (2011). Ependiontas sti figi: i diarroi epistimonon apo tin Ellada tin epohi tis pagkosmiopoiisis. Athens: Kritiki.

Matsaganis, M. (2013). I politiki kata tis ftohias stin Ellada tis krisis (Group of Public Policy Analysis Bouletin 6/2013). Athens: Kritiki.

Matsaganis, M., \& Leventi, C. (2013). I anatomia tis ftohias stin Ellada tou 2013 (Group of Public Policy Analysis Bouletin 5/2013). Athens: Kritiki.

Office of National Statistics. (2015). Population by country of birth and nationality reports, 20092015. https://www.ons.gov.uk/. Accessed 29 Sept 2015.

Parliamentary Proceedings (Praktika Olomeleias). http://www.hellenicparliament.gr/Praktika/ EvretiriaEpisimonPraktikonOlomeleias. Accessed 6 July 2014.

SER - Sociaal-Economische Raad. (2001). Labour mobility in the European Union, Abstract 01/04E, The Haag. http://www.ser.nl/en/ /media/ba46626b4f6645d8b57651c835da2be1.ashx. Accessed 30 July 2014.

Statistics Belgium. (2009). Bevolking per nationaliteit, geslacht, leeftijdsgroepen op 1/1/2009. http://statbel.fgov.be. Accessed 10 July 2014.

Statistics Belgium. (2010). Bevolking per nationaliteit, geslacht, leeftijdsgroepen op 1/1/201 http://statbel.fgov.be/ Accessed 10 July 2014.

Statistics Belgium. (2015). Bevolking per nationaliteit, geslacht, leeftijdsgroepen op 1/1/2015. http://statbel.fgov.be. Accessed 29 Sept 2015.

Statistik Austria. (2013). Wanderungsstatistik 2012 Inkl. Revision seit 2007, Wien: Bundesanstalt Statistik Österreich, January 2014. http://www.statistik.at/web_en/statistics/population/migration/index.html. Accessed 10 July 2014.

Statistik Schweiz - Bundesamt für Statistik. (2015). Ständige und nichtständige Wohnbevölkerung nach institutionellen Gliederungen,Geburtsort und Staatsangehörigkeit. http://www.pxweb. bfs.admin.ch/. Accessed 29 Sept 2015. 
Statistisches Bundesamt. (2014). Bevölkerung und Erwerbstätigkeit. Vorläufige Wanderungsergebnisse 2013, Wiesbaden, 22 May 2014. https://www.destatis.de/. Accessed 10 July 2014.

Statistiska Centralbyran. (2015). Immigrations and emigrations by country of birth and sex. Year 2000-2014, Stockholm. http://www.statistikdatabasen.scb.se/. Accessed 28 Sept 2015.

To Vima. (2013, March 1). 'Germania: H Elit ton Ergazomenon sto Deftero Revma Metanastefsis'. Triandafyllidou, A., \& Gropas, R. (2014). "Voting with their Feet": Highly skilled emigrants from Southern Europe. American Behavioral Scientist, 58(12), 1614-1633.

Zografakis, S., \& Mitrakos Th. (2012). 'O kindynos hamilou eisodimatos sti diarkeia tis trehousas krisis: I apantisi tou elahistou eggyimenou eisodimatos'. In Balourdos D. \& Petraki M. (Eds), Nea Ftoheia kai Koinonikos Apokleismos. Politikes Katapolemisis kai Kathierosi enos Elahistou Eggyimenou Eisodimatos (pp 55-83) Special Meeting of the Permanent Committee on Social Affairs, 13th Period - 3rd Term, Athens: Hellenic Parliament.

Open Access This chapter is licensed under the terms of the Creative Commons AttributionNonCommercial 2.5 License (http://creativecommons.org/licenses/by-nc/2.5/), which permits any noncommercial use, sharing, adaptation, distribution and reproduction in any medium or format, as long as you give appropriate credit to the original author(s) and the source, provide a link to the Creative Commons license and indicate if changes were made.

The images or other third party material in this chapter are included in the chapter's Creative Commons license, unless indicated otherwise in a credit line to the material. If material is not included in the chapter's Creative Commons license and your intended use is not permitted by statutory regulation or exceeds the permitted use, you will need to obtain permission directly from the copyright holder.

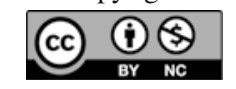




\title{
Chapter 4 \\ Emigration from Italy After the Crisis: \\ The Shortcomings of the Brain Drain \\ Narrative
}

\author{
Guido Tintori and Valentina Romei
}

In this chapter, we try to assess whether the international economic crisis, which stemmed from the credit crunch of 2007-2008 originated in the United States and the United Kingdom, has had a significant impact on Italy's migratory patterns. According to official statistics, Italy has steadily had a positive net migration since 1974, thus turning into a 'country of immigration', after a long-standing status of a 'country of emigration'. This turn in Italy's migratory balance should not convey the idea, though, that there have not been relatively significant numbers of people leaving the country even after the 1970s (Tintori 2013: 127-133). In our analysis, we focus our attention primarily on outflows from Italy towards Northern Europe, testing the conventional assumption that the country, in a sort of path dependent response, recurred to emigration as a viable remedy to economic strain and as a safety valve to release the social pressure of high level of unemployment. In the first part of the chapter, we initially consider the evolution of the financial, economic and social conditions of the country from the 1990s to 2015. We then provide a brief historical review of the migratory flows from and to Italy for the same period. This basic overview of the interaction of the economic crisis and Italy's migratory patterns works as a background to discuss more specific questions concerning current emigration: its scale, compared to past experiences; its composition, with special attention paid to the level of professional skills, sex and age; the reliability of available data. To describe in detail the socio-demographic profile of the Italian emigrants since the 2000s and their destinations we rely on Italian data collected by the ministries of the Interior and Foreign Affairs, as well as by the National statistical office (ISTAT). We critically assess the accuracy of such data against the available statistical sources from the top destination countries. In the second part of the

\author{
G. Tintori $(\bowtie)$ \\ FIERI International and European Forum on Migration Research, Turin, Italy \\ e-mail: guido.tintori@fulbrightmail.org \\ V. Romei \\ Statistical journalist at the Financial Times, London, UK
}


chapter, we analyse both the public discourse on and the policy response to the most recent outflows. In particular, we look at how the political elites discursively framed the relationship between the crisis and the outflows and to what extent the most recent outflows intertwine with the latest labour market reforms. In conclusion, we fact-check whether the hegemonic narrative focusing on the 'brain drain' is consistent with the data on the human capital of those who have left and might leave.

\subsection{A Quantitative Approach to Crisis-Induced Emigration from Italy}

\subsubsection{Current Economic and Social Situation}

Since the 1990s, the Italian economy has been suffering from a long period of sluggish or no growth. After 2007, Italy faced a series of dip recessions, which resulted in a rapid deterioration of the quality of life of her population.

The reasons behind the country's poor economic performance since the 1990s are numerous and controversial ranging from its public debt, a sclerotic bureaucracy, low productivity rates and falling competitiveness - mainly linked to relatively high unit labour costs, excessive regulation, lack of R\&D spending, an excess of small sized businesses -, political instability, inefficiency, corruption and uncompetitive marketable services (Ciocca 2007: Ch. 12 \& 13). The 2008 international crisis, therefore, hit Italy in a peculiar way, compared to other Eurozone countries, making recovery less a question of cutting expenses and bailing out the financial and bank system, than a demand for far-reaching structural reforms of the public sector and the business environment (Ciocca 2010). The international crisis of 2008 aggravated, if anything, the political and economic instability Italy has been struggling with since the early 1990s.

While all the Eurozone had a double digit growth in the last 15 years, the Italian economy did not grow at all. It grew very slowly even in the first half of 2000 when the Spanish economy, for example, rose by $17 \%$. After the crisis, even though Italy avoided any bank bailouts and the direct intervention of the European Commission (EC), the European Central Bank (ECB) and the International Monetary Fund (IMF) - the so-called 'Troika' - the country's recovery has been very weak. Compared to the same period in 2008, Italy's economy still shrank the most among both core countries - France, the UK and Germany - and some peripheral countries, including Spain, in the second quarter of 2015. Italy's was the only one to contract in 2014 among major European economies, and in the first half of 2015 it grew at half the speed of the average of the Eurozone. In the 2 years to the second quarter of 2015 the Italian GDP rose by a meagre $0.4 \%$, while the UK gained $5.7 \%$. Whatever the main reasons of "steady and prolonged decline in growth" (Tiffin 2013: 3) the consequences included lost of employment, productivity, output, savings, impoverishment of its population and lack of confidence. 
Unemployment levels started to slowly decline in 2015 but, at just below $12 \%$ of the population, they still are close to the all-time high since the 1960s. Both the EC and the IMF forecast the level to remain above the country long-term average until 2020. In Italy the level of unemployment is still much lower than in other Southern European countries - in Spain and Greece it varies between $22 \%$ and $25 \%$ - but it also hides a more general deterioration of the labour market (Ballestrero 2012; Carinci 2012). As in Italy it is relatively difficult to dismiss employees, especially in the public sector, there has been an increase of poor quality employment and unemployment among the most vulnerable groups, like the youth. According to Eurostat (2015) Italy's youth unemployment reached $41 \%$ in August 2015, the third largest in the Eurozone after Greece (48\%) and Spain (49\%). Both youth and total unemployment rates are higher among the female population. The crisis resulted in a narrowing of the gender gap in employment rates among all advanced countries. In Italy, this kind of convergence takes place at a slower pace, in that a higher proportion of women in working age were inactive, mainly because of a lack of job opportunities and rewarding careers. This is particularly worrying, as according to OECD nearly half of the Italian female population (45\%) is inactive, the third largest proportion after Turkey and Mexico. The same source shows that Italy has the second largest proportion among advanced countries after Chile for marginally attached workers, i.e. people not in the labour force because they were too discouraged to look for jobs, but willing and available to work. It also ranks third among advanced economies after Spain and the Slovak Republic for proportion of people that are working part-time because they could not find a full time job.

Over $25 \%$ of total employees in Italy are self-employed, the second highest proportion in Western Europe after Greece. The figure is, to some extent, inflated by the fact that many self-employed are de facto working full time for a different employer, since there is a lower tax wedge for independent contractors. Still, self-employment can also be seen as a survival strategy for those who cannot find any other means of earning an income. Those who do find jobs are employed with largely precarious contracts. According to the OECD more than half of the youth (15-24 years old) were in temporary contracts in 2014. Despite the current government's claims on the positive impact of the recently approved "jobs act", only one third of the new contracts registered between January and July 2015 were permanent. ${ }^{1}$ On the other side, those that are unemployed tend to be so for a long period with the risk of having rising difficulties in re-entering the labour market. Nearly $60 \%$ of the unemployed in Italy have been so for more than 1 year, the fifth largest among OECD countries and a rapid rise from $49 \%$ before the crisis.

The result is that real disposable income has been rapidly deteriorating and it is now at lower levels than in the early 1990s, while it is over $60 \%$ higher in the Eurozone. The deterioration of the labour market, in fact, is much more evident from data on poverty rather than from unemployment rates. According to Eurostat,

\footnotetext{
${ }^{1}$ Source: http://www.inps.it/bussola/VisualizzaDOC.aspx?sVirtualURL=/docallegati/DatiEBilanci /osservatori/Documents/Osservatorio_Precariato_Gen-Lug2015.pdf\&iIDDalPortale=10156. Accessed 1 October 2015.
} 
the percentage of the population that is severely deprived is much higher in Italy than in other Western European countries $(11.5 \%$ in 2014 vs. $7.1 \%$ in Spain and $5 \%$ in France and Germany). The percentage declined from its peak at $14 \%$ in 2012, but it's still double than the pre-crisis period (Eurostat 2013).

\subsubsection{Migratory Dynamics Before and During the Economic Crisis}

Since the 2000s, Italy, together with Greece, Spain and the United Kingdom, has been one of the main immigrant-receiving countries in Europe (OECD 2011: 403404). The international economic crisis has, of course, impacted on Italy's migratory dynamics. The country still attracts significant numbers of immigrants, mainly because the backbone of its productive system, made of small and medium enterprises, is in labour-intensive sectors, like fashion, agriculture and food. Italy thus continues to present a positive net migration, even though the gap between those who enter and those who leave the country every year has been shrinking, especially since 2011. Total immigration into the country, i.e. including Italian returnees, went from roughly 527,000 individuals at its peak in 2007 to almost 307,000 in 2013. Despite this decrease, yet official data show that the net international migration amounted to considerable $+142,000$ units in 2014, $+182,000$ in 2013 and $+245,000$ in 2012. On the other hand, total emigration, i.e. including foreigners leaving the country, for the same period has doubled, passing from nearly 51,000 in 2007 to over 139,000 in 2014 (ISTAT 2015, 2014).

Focussing on Italian citizens only, there is a clear growing trend of Italian nationals moving their residency abroad. The 2014 and 2013 figures - respectively, 89,000 and 82,000 - are the highest in the last 10 years (ISTAT 2014, 2015). The net migration of Italian citizens has been negative already for most of the 1990s and 2000s but since 2009 the gap is widening. Nonetheless, according to ISTAT, the number of Italian emigrants has not reached yet the levels of the 1970s.

High rates of returns, a typical trait of historical emigration from Italy, are a feature of more recent emigration patterns too. ${ }^{2}$ The numbers of Italians returning to their home country, though, are lower than they used to. For example, the nonforeign population that moved to Italy from abroad in 2012 was $20 \%$ lower than in 2007. In the 5 years to 2012, 28,000 Italian nationals moved to Italy from Germany, the same number in the previous 5 years was over 51,000. Over the same period, Italians returning from Switzerland dropped from 24,000 to 13,000. According to Eurostat, in 2012 Italy had the smallest share of returning migrants among all European countries (excluding Cyprus and Luxemburg).

The foreign population residing in Italy is increasingly leaving the country. Over 11,000 Romanians - the largest foreign-born national group in Italy - left the

\footnotetext{
${ }^{2}$ For a thorough discussion of past Italian emigrations - destinations, volumes, patterns (return or settlement) and political contexts - see (Tintori 2013).
} 
country in 2013 together with nearly 2400 Moroccans and a similar number of Albanians. At the same time, the annual inflow of the same groups is declining. It needs also to be considered that documented immigrants leaving the country have no incentives - just as natives - to de-register as residents in Italy, since it would involve loosing some benefits there, such as access to welfare service and public health care. For example, while ISTAT counted about 1500 Albanians leaving Italy in 2011, the Albanian statistics registered nearly 7000 Albanian returnees from Italy for the same year. The explanation in the mismatch of the two data, apart from possible differences in collecting them, lies also in the above-mentioned reason.

\subsubsection{Main Trends in the Current Emigration}

As everyone who has familiarity with the collection of data on international mobility knows, it is difficult to say exactly how many people are leaving or entering Italy every year. Undocumented immigration is a known problem, but undetected emigration is also an issue. Italians living abroad have a legal obligation to register in the AIRE (Registry of the Italian citizens residing abroad) at consulates, provided they have the intention of staying in that country for at least 12 month. There are no real incentives to register, since failure to comply with the law is not sanctioned and, once registered into the AIRE, the citizens lose a series of benefits in the home country, such as their access to the health service of their region of last residence, to name one. In addition, most people might not know for how long they are going to stay abroad, especially when they move to another EU member state with temporary contracts or as jobseekers. Therefore, Italians abroad register only when they are in need of a service from the consulate, typically, after quite some time. Therefore, AIRE figures are, on the one hand, very likely to underestimate the presence of Italian workers abroad, especially when their stay is temporary. Despite that, the most recent data of the AIRE show that the stock of citizens officially residing abroad has increased impressively in the last decade and totalled more than 4.5 million nationals at the end of 2014 (see Fig. 4.1). Yet, according to AIRE data less than one in four Italian residents abroad is aged between 18 and 34; a proportion that has remained unchanged from before the crisis. Once again, AIRE figures prove they are not a useful source to understand current outflows from Italy, since they include not only people who emigrated a long time ago, people born to Italian parents abroad, but most of all sizeable amounts of people who were born outside Italy and obtained citizenship by descent. According to the latest available data, in fact, between 1998 and 2010 at least 1,003,403 individuals got Italian citizenship by descent at Italian consulates abroad and were automatically added to the AIRE registry. $73.3 \%$ of the total new Italian/EU passports were released in Latin American countries (Tintori 2009, 2012).

At the same time, the ISTAT data too, based on the changes of residence administrative source, under-estimate the real-time emigration flows, since they detect only the individuals that officially move their abode overseas. However, they still 


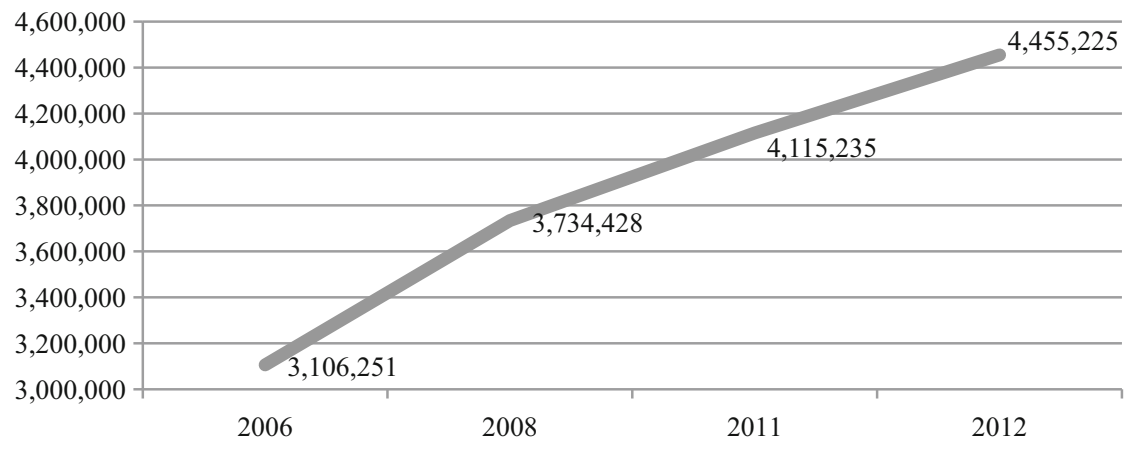

Fig. 4.1 Italian residents abroad 2006-2013 (Source: AIRE)

seem to be the best Italian source available to grasp the trends in current emigration. According to ISTAT, over 320,000 people left Italy between 2009 and 2012, $40 \%$ more than the previous 4 years. Contrary to the conventional wisdom that holds that almost exclusively southerners contributed to Italian emigration, the majority of the recent emigrants came from the northern regions of Italy. In absolute terms, the largest flow of nationals emigrating from Italy in 2012 was to Germany, Switzerland, the UK and France. In 2013, for the first time the UK took over as the most favoured destination, followed by Germany, Switzerland and France. The data on the 2014 flows confirm the UK as a booming destination (see also Chap. 10). The average age was around 34 years old and there was a prevalence of males $(57.6 \%)$ over females (ISTAT 2014). The percentage of graduates on the emigrant population above 25 years of age has increased from $11.9 \%$ in 2002 to $30.6 \%$ in 2013 . The increase of graduates among the emigrants is somehow expected, given the high competition for jobs in the international labour market, especially in the destination countries privileged by Italian graduates. The top five countries that attracted the highest percentage of highly educated Italians were, in 2013, the US (35\%), UK $(33.9 \%)$, Brazil (32.2\%), Switzerland (30.7\%), Spain (30.3\%). There is therefore a growing trend of graduates leaving the country, but the share is still by far a minority of the emigrant population. In the second part of the chapter, we will analyse better whether Italy is currently affected by a "brain drain" or not (Table 4.1).

\subsubsection{Main Destination Countries}

As showed, according to ISTAT, the largest flow of nationals emigrating from Italy in 2013 was to the UK (almost 14,000) followed by Germany $(11,400)$, Switzerland and France (around 8000-9000 to each country). In all those countries, between 2010 and 2013, the rise of emigration flow from Italy was the fastest since the mid1990s. Once again, data should be taken as a source to grasp the magnitude or trends of current emigration, not as a source of precise information. Looking at destination countries' data, therefore, might help, but even in this case we should put the data in perspective. 
Table 4.1 \% of Italian resident population (15-64) and emigrants (25-64) by educational attainment, 2002-2013

\begin{tabular}{l|l|l|l|l}
\hline \multirow{2}{*}{} & $\begin{array}{l}\text { Resident population } \\
(15-64)\end{array}$ & \multicolumn{3}{l}{} \\
\cline { 2 - 5 } & Italian emigrants (25-64) & $\begin{array}{l}\text { Secondary/higher } \\
(\%)\end{array}$ & Tertiary (\%) \\
\hline 2002 & 8.6 & $\begin{array}{l}\text { Primary/lower } \\
\text { secondary (\%) }\end{array}$ & 37.1 & 11.9 \\
\hline 2003 & 9.1 & 51 & 36.8 & 11.8 \\
\hline 2004 & 10 & 51.4 & 31.4 & 12.2 \\
\hline 2005 & 10.7 & 56.4 & 31.1 & 17.4 \\
\hline 2006 & 11.4 & 51.5 & 29 & 20.6 \\
\hline 2007 & 12 & 50.4 & 33.2 & 25.1 \\
\hline 2008 & 12.7 & 41.7 & 33.5 & 25.9 \\
\hline 2009 & 12.8 & 40.6 & 33.6 & 23.8 \\
\hline 2010 & 13 & 42.6 & 34.8 & 26.9 \\
\hline 2011 & 13.1 & 38.3 & 34.5 & 27.6 \\
\hline 2012 & 13.8 & 37.9 & 36.4 & 27.6 \\
\hline 2013 & 14.4 & 36 & 34.8 & 30.6 \\
\hline
\end{tabular}

Source: ISTAT and Eurostat

For example, if we look at the UK (see Chap. 10), according to the AIRE about 16,000 Italians registered through the local consulates in 2013, but if we consider how many Italians obtained a national insurance number (NIN) in the same year, a mandatory document that allows to work in the UK, then the figure rises to about 44,000. In 2013 the numbers of NIN allocated to Italians was $66 \%$ higher than in the previous year, the largest increase since data is available. The annual inflow of registration is four times higher than its pre-crisis levels. Over $80 \%$ of the Italian that were allocated a NIN in 2013 were below 34 years old. Forty-two percent were aged between 18 and 24, The NIN data, though, incorporate also Italians only by passport, that never actually lived in Italy, mostly Latin Americans of Italian descent that use the Italian nationality to enter the EU labour market freely (Tintori 2011). According to the UK census of 2011, in fact, nearly $10 \%$ of the UK residents holding an Italian passport were born in Latin America. Moreover, the NIN registration is mandatory for temporary and seasonal work too and it is valid for life. Therefore the numbers cannot be used to assume the actual stock of Italians living in the UK and do not tell us much about the length of their stay. On the other side, the NIN registrations do not include Italian people that are not working in the country and yet live there.

In Germany the stock of Italians increased in 2013 at its fastest rate since the 1970s. Over $80 \%$ of Italians (excluding students) living in Germany in 2012 had a degree in secondary/higher education. According to Swiss national statistics the inflow of Italian immigrants was at its peak in 1983, when it reached 12,000 people, it was below 7000 people per year in the decade to 2006, but then it jumped again and reached a record high in 2013 with over 13,000 Italian immigrants. This means that nearly 80,000 Italians officially entered Switzerland with a status of permanent 
resident in the 7 years to 2013 compared to half that size in the previous 7 years. To these figures, we should also add at least 60,000 so-called 'frontalieri' - Italian cross-border workers - who every weekday commute for work between the two countries. Even if we look at less favoured destination countries, Italian emigration appears to be on the rise. In Austria, immigration from Italy grew a 35\% in 2012 over the previous year, the fastest rate since consistent data were made available in 2002. The share of Italian immigrants aged 15-29 years old increased by $6 \%$ points to $49 \%$ between 2008 and 2013. In the Netherlands there is a similar rise of Italian immigration during the years of the crisis, especially of young people. Immigration data from other countries confirm the described trend too (Table 4.2).

An interesting exception is Belgium. Belgium recorded a long-term decline in Italian immigration that has not stopped during the years of the crisis, even if it is slightly milder. This is the result of two factors: a reduction in the influx of Italians since the 1980s - the net Italian migration flow is currently about even; and rising numbers of acquisition of Belgian nationality, which is automatic to third generation children. Despite the decline, though, Italians - together with the French - are still the largest foreign population in Belgium with over 150,000 individuals (Vause 2013; see Chap. 7).

Table 4.2 Stock and \% annual change of Italian residents in Germany, Switzerland, Austria, Belgium, 2001-2013

\begin{tabular}{|c|c|c|c|c|c|c|c|c|}
\hline & $\begin{array}{l}\text { Stock of } \\
\text { Italians in } \\
\text { Germany }\end{array}$ & $\begin{array}{l}\text { Annual } \\
\% \\
\text { change } \\
\end{array}$ & $\begin{array}{l}\text { Stock of } \\
\text { permanent } \\
\text { Italian } \\
\text { resident in } \\
\text { Switzerland } \\
\end{array}$ & $\begin{array}{l}\text { Annual } \\
\% \\
\text { change } \\
\end{array}$ & $\begin{array}{l}\text { Stock of } \\
\text { Italians } \\
\text { in } \\
\text { Austria }\end{array}$ & $\begin{array}{l}\text { Annual } \\
\% \\
\text { change }\end{array}$ & $\begin{array}{l}\text { Stock of } \\
\text { Italians in } \\
\text { Belgium }\end{array}$ & $\begin{array}{l}\text { Annual } \\
\% \\
\text { change }\end{array}$ \\
\hline 2001 & 616,282 & & 313,976 & -1.8 & & & 195,586 & \\
\hline 2002 & 609,784 & -1.1 & 308,255 & -1.8 & 1364 & & 190,792 & -2.5 \\
\hline 2003 & 601,258 & -1.4 & 303,770 & -1.5 & 1461 & 7.1 & 187,021 & -2.0 \\
\hline 2004 & 548,194 & -8.8 & 300,214 & -1.2 & 1402 & -4.0 & 183,021 & -2.1 \\
\hline 2005 & 540,810 & -1.3 & 296,392 & -1.3 & 1380 & -1.6 & 179,015 & -2.2 \\
\hline 2006 & 534,657 & -1.1 & 291,684 & -1.6 & 1467 & 6.3 & 175,498 & -2.0 \\
\hline 2007 & 528,318 & -1.2 & 289,589 & -0.7 & 1713 & 16.8 & 171,918 & -2.0 \\
\hline 2008 & 523,162 & -1.0 & 290,020 & 0.1 & 1842 & 7.5 & 169,027 & -1.7 \\
\hline 2009 & 517,474 & -1.1 & 289,111 & -0.3 & 1955 & 6.1 & 166,956 & -1.2 \\
\hline 2010 & 517,546 & 0.0 & 289,125 & 0.0 & 2167 & 10.8 & 165,052 & -1.1 \\
\hline 2011 & 520,159 & 0.5 & 290,546 & 0.5 & 2297 & 6.0 & 162,826 & -1.3 \\
\hline 2012 & 529,417 & 1.8 & 294,359 & 1.3 & 3095 & 34.7 & 159,727 & -1.9 \\
\hline 2013 & 552,943 & 4.4 & 301,254 & 2.3 & & & 157,426 & -1.4 \\
\hline
\end{tabular}

Source: Statistical office of Germany, Switzerland, Austria and Belgium 


\subsection{Policies and Debates}

The Italian State has traditionally looked at the emigrants and their descendants as commercial and economic outlets and a key instrument for promoting its political role in the international arena (Tintori 2013: 143-146). Even during the period of the so-called 'Great Emigration' at the turn of the twentieth century and again during the second wave of mass emigration after World War II, when Italians were leaving by the millions per decade, the concern about the 'haemorrhage' of economically active population was short-lived. It was quickly replaced by the argument that saw emigration as a safety valve to deal with unemployment and a prospect to establish 'colonies' of consumers of Italian products abroad. More ambitiously, the presence of an Italian diaspora was exploited to project the nation's prestige, economy and labour market internationally (Manzotti 1962; Choate 2008; Tintori and Colucci 2015).

In terms of policy response, the Italian State has historically displayed a high degree of activism in promoting tailor made measures for the citizens abroad and their descendants. Since the 1970 s - to consider the post-war period only - the institutions involved ranged from local level administrations - e.g. Regioni and Comunito governmental departments - e.g. Ministry of Foreign Affairs, of Labour, of the Interior, of the Economy - and ad hoc created public agencies. Provisions varied between economic incentives to return, welfare and pension schemes provided directly abroad, training and educational programs, Italian language schools abroad, and climaxed in 2000-2001 with the adoption of the legislation on external voting that allocated 18 dedicated seats for the external citizens in representation of 4 global electoral macro-districts (Tintori 2013: 140-143; Lafleur 2013: 78-87). In a context of continuity, it is therefore noteworthy to assess whether there has been a shift in the contents and intensity of the Italian State's activities dedicated to the citizens abroad since 2008, as a response to the increase in the outflows of the recent years.

\subsubsection{Public Discourse After the Crisis}

As the first section showed, between 1990 and 2014, with the exception of the 2002-2004 period, the net migration rate of Italian citizens has been negative. This means that, even though its dimension waxed and waned, emigration, already mainstreamed into the narrative of the nation, has not ceased to be a permanent trait of the Italian society, economy and culture. Three main interwoven public discourses dominated the debate regarding recent emigration.

The first, up to the crisis, was mainly proposed by some experts and academics and was quickly adopted in media representations and descriptive, mostly autobiographical essays (Altreitalie 2011; Cucchiarato 2010; Soffici 2014). It described the recent migratory waves as the so-called nuove mobilità ("new mobility"), in order 
to mark the distance from the mass emigration of the past, in that the latter featured humble, unskilled, poorly educated individuals and families forced to leave the country out of sheer misery, with nothing but cardboard suitcases, relying on the chain migration system to find a job at destination; while the former resonates much more with the population of the so-called "Eurostars" (Favell 2008), a generation of highly skilled and intensely mobile people who are equipped to roam between "Eurocities" and global capitals to make the best out of the "human face" of globalization (Favell et al. 2006).

The second, prominent especially after the crisis and the growth in emigration rates, was a further development of the first with a note of pessimism added to it. It is still pivoted on the young and talented, the highly skilled, the graduates, the "best of Italy" (Tirabassi and Del Prà 2014), who would be forced - rather than choose to leave the country in growing numbers, since Italy is ruled by the elderly and they are not offered anything but fixed-term contracts, unrewarding career-prospects, and peanuts-paid jobs. Members of the political elites contributed to this narrative through public statements that prompted nationwide discussions on the brain drain'. For example, in November 2009, Pier Luigi Celli, the dean of the Romebased private University LUISS, funded by the association of Italian entrepreneurs, published an open letter to his son on one of the leading newspapers, La Repubblica, in which he advised him to leave the country as soon as he graduated. ${ }^{3}$ By the same token, Fabrizio Barca, then minister of Mario Monti's government, declared in 2012 that leaving the country was the right choice for young graduates, citing the example of two out of three of his sons that had started a career in Latin America and in the UK. ${ }^{4}$ As a result, this explicit, almost exclusive focus on talent and emigration of graduates through the media, popular blogs ${ }^{5}$ and the political elites, has popularized the phrase 'fuga dei cervelli' - the Italian equal for brain drain -, which is applied indiscriminately to every (relatively) young Italian who goes overseas, regardless of their qualification and occupation.

This only partially true and extremely over-simplistic rendition of Italy's current mobility patterns, even in the academic realm, relies essentially on qualitative and human-centred empirical research that samples on the dependent variable. It does not delve into the actual data on the human capital of those who leave, their occupation, wage levels, type of job contracts, and length of stay abroad. As we have only started to demonstrate in the first part of the chapter, though, if there is enough evidence to state that the recent rise of emigration - especially that undetected by Italian official data - was significantly composed of young people, there are no solid

\footnotetext{
${ }^{3}$ Pier Luigi Celli, "Figlio mio, lascia questo Paese", La Repubblica, 30 November 2009. http:// www.repubblica.it/2009/11/sezioni/scuola_e_universita/servizi/celli-lettera/celli-lettera/celli-lettera.html; last accessed 13 August 2014.

4 “Barca: 'Fuga di cervelli? Se Italia non migliora è giusta"”, La Repubblica, 16 April 2012, http:// www.repubblica.it/scienze/2012/04/16/.../barca_fuga_di_cervelli_se_italia_non_migliora_ giusta-33394354/; last accessed 17 April 2014.

${ }^{5}$ Among the most popular blogs are Italians by Beppe Severgnini, journalist of one of the most important Italian newspapers, Il Corriere della Sera, and Giovani Talenti (Young talents) hosted by Sergio Nava, journalist of the main economic Italian newspaper Il Sole 24Ore.
} 
proofs that they bring the 'brain' too with them, as they are not necessarily skilled or they don't necessarily end up working in highly-skilled sectors. In the next and final section, we will add a few more words on the issue, by looking at the data on the human capital of those who have left or might leave.

Third discourse: the principal Italian daily newspapers, the liberal La Repubblica and the moderate Il Corriere della Sera, have joined the 'brain drain frenzy' and feature regular contributions, in their online versions especially, that spotlight the 'haemorrhage' of the best part of the population. ${ }^{6}$ This kind of reportages has often been associated to the difficulties that Italy faces in integrating her immigrants. Probably an unintended outcome, the alarmed tones characterizing these discourses have led to a political climate where an 'Italians first' argument and an antiimmigrant backlash have become politically legitimate, even more so in the context of growing competition for jobs. Thus, not only the traditionally anti-immigrant campaigns of the Northern League are now recrudescing, but also the minister of the Interior, Angelino Alfano, member of the broad coalition government led by Matteo Renzi, recently declared that the government will not allow that even "a single immigrant take the job of an Italian citizen"?

\subsubsection{Political Initiatives}

The long-standing dynamism of the Italian state towards the 'Italians abroad', a phrase that indistinctly conflates both the emigrants and the descendants of former emigrants, makes it difficult to single out which policies and/or agencies have been developed as a reaction to the growth of outflows after the crisis. In addition, in the course of - even recent - history, a plethora of institutions have been in charge to deal with the 'Italians abroad'. In this section, we provide a first review of the measures undertaken since 2008. We examine whether there has been a shift in the contents and intensity of the governmental activities towards the emigrants, if these measures are dependable on the described public discourses that accompanied the recent outflows, and whether they are consistent with the available data on 'those who leave', Italy's economic situation and labour market.

Since the 1990s, and even more intensely between 2000 and 2007, virtually all of the 20 Italian regional administrations passed legislative acts that reached out for their reference communities of 'Italians abroad'. Provisions encompassed a wide range of policies: social subsidies, vocational training and co-development projects, programmes aimed at facilitating 'co-ethnic' returns, cultural exchange trips, tourism, and so forth. After the crisis, a minority of experts and politicians, especially

\footnotetext{
${ }^{6}$ See, for example, the ad hoc created video-reportage format Domicilio Londra (Domicile: London) by La Repubblica: http://video.repubblica.it/rubriche/domicilio-londra

7 “Alfano: 'Non accetteremo che un immigrato prenda il posto di un italiano', La Repubblica, 1 August 2014, http://www.repubblica.it/politica/2014/08/01/news/alfano_-92937945/: last access 2 August 2014.
} 
those with an academic background, assuming a high degree of return or circularity of the current outflows have tried to frame the 'Italians abroad' question mainly as an opportunity and not necessarily as a problem, a potential occasion to further develop the labour force's human capital, improve the balance of trade and of payments, and a chance to transform the 'brain drain' into a 'brain return' (ISPI 2012). A more systematic study is still needed, but it seems that more recently the main efforts of both state-level agencies and local administrations have been directed, on the one hand, towards the establishment of ethnic business communities and, on the other, towards the return of individuals with improved human and social capital.

As recently as 30 December 2010, the then Berlusconi's government approved a measure (Law 238) formally aimed at attracting EU skilled citizens to move and work in Italy. The law grants tax incentives to EU citizens born after 1969, who have been working or have graduated abroad but have resided for at least 2 years in Italy in the past. The incentives are accorded if they start new business activities in Italy or are hired permanently by an Italian employer. As a matter of fact, the law is primarily targeting Italian nationals, as an attempt to pave the way for the return of the skilled and young emigrants. In fact, the measure, which is advertised in Italian only, includes a series of ancillary privileges for Italian citizens alone, in terms of access to public housing and pension benefits. It also creates a privileged bureaucratic channel for the Italian applicants in order to speed up their procedures, through a collaboration between the Italian consulates and the agency Italia Lavoro SpA, created in 1997 and controlled by the Ministry of the Economy. Incidentally, these actions were undertaken concurrently with the adoption of policies that retrenched the social and economic rights of third country nationals regularly residing in Italy and made more demanding the procedures to get their residence permits renewed.

The 2010 Law and the hegemonic narrative on the 'brain drain' became the foundation of ensuing actions taken both at the local and state level. The Umbria region has launched the programme 'Brain Back Umbria', which further develops its Regional Law 37 of 1997. The programme, financed mainly through the European Social Fund, focuses exclusively on former residents of the region living abroad. It grants tax incentives for new businesses and start-ups set up in the region, as well as seed money - 5000 Euros - for researchers. ${ }^{8}$ Similarly, the municipality of Milan has launched the portal "Welcome Talent", in cooperation with the blog Italents and few local scholars. The programme, through the action called "Welcome Business", allocated 510,000 Euros to 'talented returnees' in order to start a new business in Milan. In 2012, under Monti's government, the Ministry of the Interior and the Ministry of Education activated the platform "Innovitalia" whose goal is to "maximise the impact of human capital" of the Italian "brains" abroad and "promote research and business opportunities" in partnership with the motherland. ${ }^{9}$

These actions are certainly consistent with the hegemonic narratives concerning the current emigration, where both the governmental rhetoric and media reports

\footnotetext{
${ }^{8} \mathrm{http}: / / \mathrm{www} \cdot$ brainbackumbria.eu/index.php last access 12 August 2014.

${ }^{9} \mathrm{http}: / / \mathrm{www}$. innovitalia.net/crowdforce/product/index.html last access 12 August 2014.
} 
insist on the presence of graduates. Yet, the available data show that the percentage of graduates, though on the increase, is by far a minority not only in the stock but also in the yearly emigrant population.

In some respects, Italy presents all the prerequisites for suffering from a 'brain drain' issue. Education did not help much to avoid economic distress. Unemployment rates among those with a tertiary education were about $11.5 \%$ of the young population (25-34 years old) in 2011, an even larger proportion than among those with secondary education $(10.5 \%)$ and not so smaller than the unemployment rate of those without education $(14.8 \%)$. In other countries, university degrees are much more rewarding in terms of employability. For example, in Germany youth unemployment rates drop from $20 \%$ among those with no qualification to $2.7 \%$ among those with a tertiary degree. France shows a similar gap (23\% vs. 6\%) and even in Spain where unemployment rates are higher, earning a degree makes a decisive difference in the labour market (33\% with no qualification vs. $16 \%$ among graduates) (OECD 2013a).

On the other hand, comparative studies show that Italy does not export more graduates than other developed countries - in the EU, for example, Germany, France and the UK have higher percentages of graduates leaving the country - but has instead a problem of 'brain circulation', in that it is not able to attract significant numbers of educated foreigners (Franzoni et al. 2012; Beltrame 2007). The asymmetric treatment reserved to the 'Italians abroad' and third country nationals in the allocation of rights and access to incentives might play a decisive role here. In addition, Italy might not export many graduates as expected simply because, first, there are not so many and, second, they may not be necessarily fit to participate in the global labour market. Italy ranked second to last for tertiary educational attainment among all OECD countries - only Turkey had worse rates - regardless of whether the whole population was considered or only the youth cohort (25-34 years old) (OECD 2013b). By the same token, in 2013 Italy scored poorly, last place among 20 OECD countries, for percentage of adults (aged 16-65) who worked in skilled occupations during the previous 5 years (OECD 2013c: 442). Enrico Giovannini, then minister of Labour in Letta's government, commenting on these data, bitterly observed that the average poor human capital of most of the Italian young people made them simply unemployable, when it came to the demands of the international labour market. ${ }^{10}$

Italian consulates have probably a better pulse of the kind of emigration that is taking place from Italy. Massimiliano Mazzanti, the Italian consul in London, confirmed that the UK is a booming destination for Italians looking for a job. Their profiles and qualifications vary extensively, but only a minority ends up working in the City or in highly skilled occupations. As a matter of fact, a growing number of scams have been reported, in which Italian newcomers are requested payment for

\footnotetext{
10 "Giovannini su dati Ocse: 'Dimostrano che italiani poco occupabili”, La Repubblica, 9 October 2013, http://www.repubblica.it/scuola/2013/10/09/news/giovannini_su_dati_ocse_dimostrano_ che_italiani_poco_occupabili-68246867/ last access 12 August 2014.
} 
accommodation and access to work by fellow citizens and locals ${ }^{11}-$ a sort of historic recurrence of the ethnic-broker or padrone system that accompanied Italy's great emigration of the past. That is why the consulate, in January 2014, launched the "Primo Approdo" (First Landing) project, which offers a downloadable handbook as well as in person meetings with experts to provide young Italians with information on how the labour market, the educational, social, health and legal systems function in the UK. Even more recently, the Italian consulate in Melbourne has hosted a photographic exhibition at the local Museo Italiano, significantly titled What I have to do/What I would like to do, by Cristian Iotti. The exhibit witnesses the stories of many young Italians who have recently arrived in Australia and have adapted to all kind of occupations in order to make a living, while still pursuing their individual dream-job.

\subsection{Conclusion}

There is a clear and growing trend of Italians emigrating from the country after the economic crisis. The figure on emigration of 2014, the highest since the mid-1970s, counts for 1.4 emigrants for every 1000 of the Italian population. As described in the first section of the chapter, numbers, composition, profile and duration of the most recent and current outflows from the country are still somehow uncertain. Yet, they are undoubtedly not comparable in size - both in absolute and relative numbers - with mass departures of the two waves of the historical great emigration. There are enough data to affirm that it is mostly the young to emigrate, as it is usually the case, but there is no solid evidence yet to assert that the majority are also highly-skilled or - educated. Partially, emigration of the young is due to the increased movements of people in a globally interconnected labour market. But the most likely explanations to account for the increase in the emigration rate after the crisis should be sought in the combined effect of two factors: the long period of sluggish or no growth of the economy since the 1990s, which has progressively impoverished the country's household incomes, and the latest labour market reforms, that between 2003, with the law n. 276 of 20 September, and 2012, with the law n. 92 of 8 June, - the so-called Biagi and Fornero Laws, respectively - have heavily deregulated the labour market and introduced flexibility. The reforms, in particular, have a direct responsibility in pushing young people out of the country, since they have aggravated the labour system's segmentation, in which a relevant part of Italy's workforce, with a majority of males and members of the older generations, holds hyper-protected life-long contracts, while a sizeable minority, virtually all of the new employed, has access almost exclusively to insecure, highly-flexible, low-paid jobs (Berton et al. 2012; Simoni 2009). There where more detailed data on

\footnotetext{
11 “Interview with Italian Consul in London, Massimiliano Mazzanti”, L'ItaloEuropeo, 21 February 2014, http://www.italoeuropeo.com/interviews/1539-interview-with-italian-consul-in-london-massimiliano-mazzanti last access 12 August 2014.
} 
the occupation of current Italian emigrants are available and as testified by recent initiatives undertaken by the Italian consular authorities, the hegemonic narratives focussed on the 'brain drain' issue and the export of talents appear to be misleading. They should, at best, speak of 'brain waste'. In fact, on the national labour market front, Italy is not able to participate in the brain circulation system and attract a number of skilled immigrants sufficient to match the relatively average percentage of her graduates and $\mathrm{PhDs}$ that are leaving. It does not reward adequately the young and educated either, who are very often confined to unattractive careers, underpaid and underemployed. On the international labour market front, Italian adults lack the key skills to compete with their peers, constantly ranking in the last place in Europe in terms of foreign languages, numeracy and ICT proficiency (OECD 2013c). Despite these evidences, the public discourse on emigration has adopted quite alarmed tones, since it has focused primarily on the 'brain drain' issue. More worryingly, it has become a field where to display ethno-nationalist arguments and antiimmigrant backlash.

\section{References}

Altreitalie. (2011) Special Issue "Le nuove mobilità", 43.

Ballestrero, M. V. (2012). Declinazioni di flexicurity. La riforma italiana e la deriva spagnola. Lavoro e Diritto, 26(3-4), 441-464.

Beltrame, L. (2007) Realtà e retorica del brain drain in Italia. Stime statistiche, definizioni pubbliche e interventi politici. Trento, Università di Trento, Dipartimento di sociologia e ricerca sociale: Quaderno 35.

Berton, F., Richiardi, M., \& Sacchi, S. (2012). The political economy of work security and flexibility. Italy in comparative perspective. Bristol: The Policy Press.

Carinci, M. T. (2012). Il rapporto di lavoro al tempo della crisi: modelli europei e flexisecurity "all'italiana" a confronto". Giornale di diritto del lavoro e di relazioni industriali, 136, 527-572.

Choate, M. I. (2008). Emigrant nation. The making of Italy abroad. Cambridge, MA: Harvard University Press.

Ciocca, P. (2007). Ricchi per sempre? Una storia economica d'Italia (1796-2005). Turin: Bollati Boringhieri.

Ciocca, P. (2010). La specificità italiana nella crisi in atto". Moneta e Credito, 63(249), 51-58.

Cucchiarato, C. (2010). Vivo altrove. Giovani e senza radici: gli emigranti italiani di oggi. Milan: Bruno Mondadori.

Eurostat. (2013). In 2012, a quarter of the population was at risk of poverty or social exclusion. Newsrelease 184/2013.

Eurostat. (2015). EURO area unemployment rate at 11.4\%. Newsrelease 20/2015.

Favell, A. (2008). Eurostars and Eurocities. Free movement and mobility in an integrating Europe. Oxford: Blackwell Publishing.

Favell, A., Smith, M. P., \& Recchi, E. (Eds.). (2006). The human face of global mobility: International higly skilled migration in Europe, North America and Asia Pacific. New Brunswick: Transaction.

Franzoni, C., Scellato, G., \& Stephan, P. (2012). Foreign born scientists: Mobility patterns for sixteen countries (NBER Working Paper 18067).

ISPI (Istituto per gli studi di Politica Internazionale) (Ed.). (2012). La risorsa emigrazione gli italiani all'estero tra percorsi sociali e flussi economici, 1945-2012 (Report n. 60). Rome: Senato della Repubblica. 
ISTAT. (2014) Migrazioni internazionali e interne della popolazione residente - Anno 2013. Istat Annual Report 9 December 2014.

ISTAT. (2015). Demographic indicators. Estimates for the year 2014. Report, 12 February 2015.

Lafleur, J.-M. (2013). Transnational politics and the state. The external voting rights of diasporas. New York: Routledge.

Manzotti, F. (1962). La polemica sull'emigrazione nell'Italia unita: fino alla prima guerra mondiale. Milan: Dante Alighieri.

OECD. (2011). International migration outlook 2011. Paris: Sopemi - OECD Publishing.

OECD. (2013a). Education at a glance 2013: OECD indicators. Paris: OECD Publishing.

OECD. (2013b). Educational attainment. In OECD factbook 2013: Economic, environmental and social statistics (pp. 188-189). Paris: OECD Publishing.

OECD. (2013c). OECD skills outlook 2013: First results from the survey of adult skills. Paris: OECD Publishing.

Simoni, M. (a cura di) (2009). URG! Urge ricambio generazionale, Rubbettino, Soveria Mannelli.

Soffici, C. (2014). Italia yes, Italia no. Che cosa capisci del nostro paese quando vai a vivere a Londra. Milan: Feltrinelli.

Tiffin, A. (2013). European productivity, innovation and competitiveness: The case of Italy (International Monetary Fund Working Paper, 14/79).

Tintori, G. (2009). Fardelli d'Italia? Conseguenze nazionali e transnazionali delle politiche di cittadinanza italiane. Rome: Carocci.

Tintori, G. (2011). The transnational political practices of 'Latin American Italians'. International Migration, 49(3), 168-188.

Tintori, G. (2012). More than one million individuals got Italian citizenship abroad in twelve years (1998-2010). EUDO Citizenship News, 21 November.

Tintori, G. (2013). Italy: The continuing history of emigrant relations'. In M. Collyer (Ed.), Emigration nations. Policies and ideologies of emigrant engagement (pp. 126-152). Basingstoke: Palgrave Macmillan.

Tintori, G., \& Colucci, M. (2015). From manpower export to brain drain? Emigration and Italy, between past and present'. In A. Mammone, E. Giap Parini, \& G. Veltri (Eds.), Routledge handbook of contemporary Italy: History, politics, and society (pp. 37-48). New York: Routledge.

Tirabassi, M., \& Del Prà, A. (2014). La meglio Italia. Le mobilità italiane nel XXI secolo. Turin: Accademia University Press.

Vause, S. (2013). Migrations et populations issues de l'immigration en Belgique. Rapport statistique et démographique 2013. Louvain: Centre de Recherche en démographie et sociétés (DEMO).

Open Access This chapter is licensed under the terms of the Creative Commons AttributionNonCommercial 2.5 License (http://creativecommons.org/licenses/by-nc/2.5/), which permits any noncommercial use, sharing, adaptation, distribution and reproduction in any medium or format, as long as you give appropriate credit to the original author(s) and the source, provide a link to the Creative Commons license and indicate if changes were made.

The images or other third party material in this chapter are included in the chapter's Creative Commons license, unless indicated otherwise in a credit line to the material. If material is not included in the chapter's Creative Commons license and your intended use is not permitted by statutory regulation or exceeds the permitted use, you will need to obtain permission directly from the copyright holder.

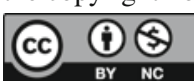




\title{
Chapter 5 \\ Structural Emigration: The Revival of Portuguese Outflows
}

\author{
José Carlos Marques and Pedro Góis
}

\subsection{Introduction}

Over the last 20 years the social, political and academic importance attached to Portuguese emigration, and in particular to emigration flows, has contrasted with the size and social significance of the migratory outflows during these years. Considered a feature of the past, and associated with a reality marked by low levels of development, emigration did not readily fit into the narrative of economic and social development promulgated during this period. Statistical data provided by host countries, however, shows that since the mid-1980s, and especially in the early years of the new millennium, the outflows of Portuguese citizens intensified, new emigration destinations such as Angola, Brazil, and the UK emerged, traditional destinations of emigration (e.g. France and Switzerland) became more developed, and forms of migration became more diverse. This diversification is one of the most distinct characteristics of current Portuguese emigration movements, noticeable through the development and combination of different forms of mobility (shortterm, temporary and more permanent) and the modification of emigrants' sociodemographic characteristics. Although emigration of citizens with few qualifications continues to be dominant, it is noticeable that there is an increase in highly qualified migrants. On the following pages we will, firstly, analyse current Portuguese emigration, showing that it is influenced by an interaction of economic factors and preexisting migration networks that structurally support on-going emigration flows, which have become geographically more diverse due to the development of mobility opportunities within and beyond Europe. In the European case these

\footnotetext{
J.C. Marques $(\triangle)$

Polytechnic Institute of Leiria and CICS.NOVA (Unit Leiria), Leiria, Portugal e-mail: jclaranjo@sapo.pt

P. Góis

Faculty of Economics, University of Coimbra and Centre for Social Studies, Coimbra, Portugal
} 
opportunities have led to the expansion of mobility patterns based on multiple interconnections between Portugal and the destination countries, and by a continued intense participation in a labour market delimited by the borders of the European Union and by the borders of countries with which it has special agreements.

In the second section, we will reflect on both the relations of the Portuguese State with its emigrant communities abroad, and the current political debates on the recent increase in emigration flows. We emphasize that these debates have not been followed up by policies directed towards new Portuguese emigration structures, and that they continue to be based on the image of emigration from the past century.

\subsection{Portuguese Migratory Dynamics and Volumes in the Last Decades}

Emigration had, for the last couple of centuries, been a "structural constant" (Godinho 1978) of the Portuguese society. The outflows were directed to different geographical regions according to the demands of the international labour market. Like several other European countries, Portugal participated in the two great migratory waves of the nineteenth and twentieth century (the transoceanic, and the intraEuropean migratory flows). ${ }^{1}$ During the first wave more than two million people left Portugal for the new world (mainly for Brazil), and throughout the second wave, which lasted roughly from the 1950 s to 1974 , almost as many individuals left, predominantly for other countries in Europe (particularly France and Germany) (Baganha et al. 2005).

Between 1974 and 1985 permanent emigration decreased significantly and return migration registered a strong increase. During the 1980s, 1990s, and the first decade of the new millennium, Portugal recorded, like other Southern European countries, a remarkable increase in the foreign resident population - from 58,091 in 1980 to 451,742 in 2009. This deep transformation of the Portuguese migratory landscape nurtured the development of a social and political (and also scientific ${ }^{2}$ ) discourse on the absence of continuing outflows, that contrasted with the size and social significance of the actual emigratory flows recorded during these years. Considered to be a characteristic of the past and associated with a reality marked by low levels of development, emigration did not readily fit into the dominant narrative of economic and social development during this period.

However, as frequently happens, data contradicts this dominant definition of reality. After the mid-1980s there is evidence of a revival in the outflow of Portuguese nationals, which is characterized by three main elements: a transformation of the institutional context in which it occurred, the development of new destination countries (see below), and the emergence of new forms of migration (see Sect. 5.4). At

\footnotetext{
${ }^{1}$ On these two waves see, among others, Arroteia (1983), and Serrão (1982), and for a synthesis Baganha et al. (2005), and Marques and Góis (2013).

${ }^{2}$ See, for example, the book on the 'end of the migratory cycle' to Europe (Paiva 1985).
} 
Table 5.1 Portuguese citizens living in selected European countries, 1985-2013

\begin{tabular}{l|l|l|l|l|l|l}
\hline & 1985 & $1990 / 1$ & $2000 / 1$ & 2005 & $2010^{\mathrm{b}}$ & $2013^{\mathrm{b}}$ \\
\hline Belgium $^{\mathrm{a}}$ & 9,500 & 16,538 & 25,600 & 27,373 & 33,084 & 38,813 \\
\hline France $^{\mathrm{b}}$ & - & 599,000 & 571,000 & 492,000 & 495,454 & $509,254^{\mathrm{g}}$ \\
\hline Germany $^{\mathrm{a}, \mathrm{c}}$ & 77,000 & 92,991 & 133,700 & 115,606 & 113,208 & 127,368 \\
\hline Luxembourg $^{\mathrm{d}}$ & - & 39,100 & 58,450 & 67,800 & 79,800 & 88,200 \\
\hline Spain $^{\mathrm{a}, \mathrm{e}}$ & 23,300 & 33,268 & 42,000 & 66,236 & 142,520 & 129,079 \\
\hline Switzerland $^{\mathrm{f}}$ & 30,851 & 85,649 & 134,675 & 180,765 & $238,432^{\mathrm{f}}$ & $253,769^{\mathrm{f}}$ \\
\hline United Kingdom $^{\mathrm{a}}$ & - & - & 58,000 & 73,000 & 102,000 & 143,000 \\
\hline
\end{tabular}

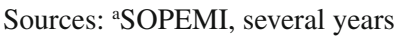

bobservatório da Emigração (http://www.observatorioemigracao.secomunidades.pt)

'Statistische Bundesamt Deutschland, Statistische Jahrbuch, several years

${ }^{\mathrm{d}}$ Service central de la statistique et des études économiques (STATEC)

'Instituto Nacional de Estadística. Series Anuales Padrón Municipal de Habitantes (several years)

fBundesamt für Migration, Ausländer- und Asylstatistik

g2012 data

the institutional level, when Portugal became a member of the European Economic Community (EEC) in 1986, new conditions were created for the movement of Portuguese workers (and, incidentally, for a lack of visibility of emigration movements, because official statistics on exits to other European countries ceased in 1988). In 1992 Portuguese nationals gained access to a European area in which the free movement of people was possible. This seemed to create adequate conditions for a recovery in the outflow of Portuguese citizens, mainly directed towards the northern European countries that, until the abrupt halt of the early 1970s, were the main destinations of Portuguese emigrants. The data on the arrival of Portuguese citizens in some destination countries provided by Baganha (1993), Peixoto (1993), and Baganha and Peixoto (1997), show that between 1985 and 1990, Portugal experienced an increased frequency of exits (on average 33,000 individuals per year left the country during this period, mainly to non-EU countries) which, nevertheless, was substantially lower than that recorded during the preceding decades.

Another indicator of this increase in the external mobility of Portuguese citizens can be revealed through an analysis of the changing numbers of Portuguese nationals residing in other European countries. Table 5.1 shows a continuous increase in Portuguese citizens living in selected European countries after 1985. This increase is explained, not only by the natural increase in the number of Portuguese citizens already living abroad, but also by new migratory movements.

It is particularly significant that in several of the selected countries, the total number of Portuguese citizens more than doubled between 1985 and 2000, thus clearly showing that the notion of an end to the Portuguese migratory movements, repeatedly asserted at the beginning of the new millennium, was a de facto illusion.

The marked increases (in both absolute and percentage terms) recorded in countries in which the presence of Portuguese nationals was, until the 1980s, nearly insignificant, indicate that from that time onwards Portuguese emigrants found 
Table 5.2 Portuguese-born living in selected European countries, 2000-2013

\begin{tabular}{l|l|l|l|l}
\hline & $2000 / 1$ & 2005 & 2010 & 2013 \\
\hline Belgium & 21,189 & 23,300 & 28,310 & 31,564 \\
\hline France & $571,874^{\mathrm{a}}$ & 567,000 & 588,276 & $599,333^{\mathrm{b}}$ \\
\hline Germany & 108,397 & 92,251 & 90,148 & 104,084 \\
\hline Spain & 58,364 & 80,846 & 148,154 & 134,248 \\
\hline Switzerland & 100,975 & 132,872 & 172,274 & 211,451 \\
\hline United Kingdom & 34,000 & 57,000 & 83,000 & 110,000 \\
\hline Total Europe & $1,292,536$ & & $1,529,237$ &
\end{tabular}

Sources: Pires et al. (2014), Branco (2013), and Observatório da Emigração (http://www.observatorioemigracao.secomunidades.pt)

Notes: ${ }^{\mathrm{a}} 1999$ data

b2012 data; data for Luxembourg is not available

alternative destinations to the traditional receiving countries of migrant labour forces. The cases of Switzerland and the United Kingdom are particularly illustrative of the creation and consolidation of new migratory destinations; in these two countries the Portuguese became a significant foreign community in a relatively short period of time.

Data on Portuguese-born people living in another European country (Table 5.2) confirms that the increase described was particularly evident after 2005, and that a substantial part was due to new migratory movements.

The upsurge in Portuguese emigration during the 2000s and particularly since 2005 is also observable in the data on the inflow of Portuguese citizens to some other European countries. This data shows that emigration resumed its growing trend, after a temporary interruption between 2007 and 2010 due to the economic crisis experienced by some of the potential destination countries of Portuguese emigrants (e.g. Spain) (Table 5.3).

Taken together, the data presented in the preceding tables illustrate simultaneously the significance of Portuguese integration in the Western European migration system, and the variety of migratory destinations that emerge and develop in different national frameworks. The maintenance of these migratory destinations is contingent on the evolution of the opportunity structures and/or the emergence of alternative migration structures (Marques 2008, 2009). So, for example, the reduction of the emigration flow to Spain (due to a decrease in job opportunities in this country) was compensated, from 2010 onwards, by an increase of the inflow of Portuguese citizens to Germany and especially to the UK.

Though striking, the data presented above does not capture entirely the dimension of the Portuguese outflows after 2005. Available data (see below) show that, in addition to the European destination countries, the current emigration flow is heading toward destinations that until now only marginally functioned as host countries for Portuguese migrants. Thus, Portuguese emigration destinations have become geographically more diversified, complementing the integration into the Western European migration system with an increased participation, as a country of origin, 


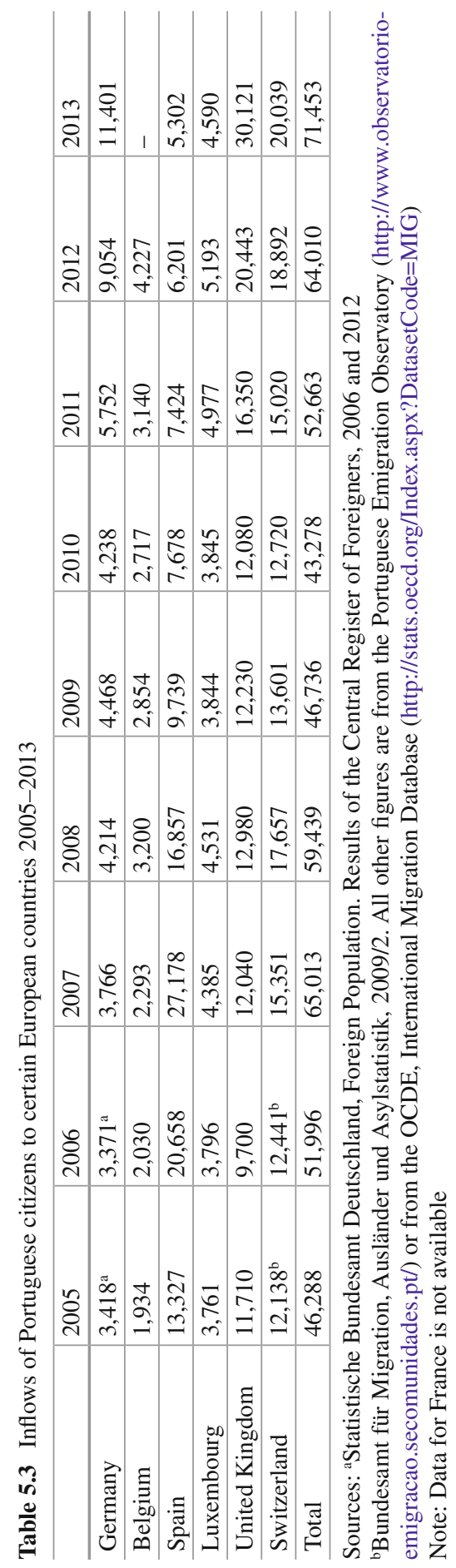


in the Lusophone migration system. In this last migration system the cases of Brazil and Angola are paradigmatic of the development of new destinations for Portuguese emigration due to the marked economic growth experienced by these countries in the last few years. In Angola the number of Portuguese emigrants entering the country increased from 156 in 2006 to 23,787 in 2009. In 2013 there were around 115,000 Portuguese citizens living in Angola. ${ }^{3}$

Although available official data is insufficient to describe the evolution of Portuguese migratory flows to Brazil, there is evidence that it has increased in the last few years. Thus, for example, work visas issued to Portuguese citizens in Brazil rose from 477 in 2006 to 2,913 in 2013, and the number of Portuguese residents in Brazil registered at a Portuguese Consulate increased from 493,227 in 2008, to 558,737 in 2012. ${ }^{4}$ Although incomplete, these figures show a clear growth in Portuguese emigration to Brazil and Angola that reversed the migratory movements which took place during the 1990s and early years of the twenty-first century.

We should state that an element of these flows to Brazil and Angola (and also to other Lusophone countries) could include an unknown number of citizens from these countries who previously migrated to Portugal, and during their stay in the country acquired Portuguese citizenship.

In sum, in the new millennium, and particularly with the beginning of the 2008 economic crisis, Portuguese emigration went both to traditional destinations and to new destinations. The participation in various migration systems, each at different phases, is able to compensate for any reduction in employment opportunities in a particular destination, or to react to an increase in the national emigration pressure. Portuguese emigration becomes therefore geographically more diverse, adding to its ability to include new European countries as effective host countries, the capacity to include destinations that overstep the borders of the European continent.

Annual estimations of Portuguese outflows made by the Portuguese Statistical Office confirm, for 2011 and 2012, the return to substantial emigration flows. According to these data 222,396 emigrants left the country, $43.1 \%$ of them permanently. If we compare these data with the average outflow during the most intense period of Portuguese emigration in the twentieth century (on average 97,695 emigrants left the country each year between 1960 and 1974) it is possible to suggest that the idea of a return to the past is an adequate description for the current migratory situation.

An accurate description of the social and demographic characteristics of contemporary Portuguese emigration is, due to data limitations, unfortunately not possible. We believe, however, that in these respects the current emigrants reproduce, with some alterations, the features already present in previous emigration flows. The changes observed in contemporary movements result either from changes in the international labour market (and, in particular, in the demand for migrant workers in the major destination countries of Portuguese migrants), and from transformations in Portuguese society itself. Together these changes contribute to certain distinctive

\footnotetext{
${ }^{3}$ Data from http://www.observatorioemigracao.secomunidades.pt/np4/paises.html $\mathrm{id}=9$

${ }^{4}$ Data from http://www.observatorioemigracao.secomunidades.pt/np4/paises.html?id=31
} 
characteristics of the Portuguese emigrants of the twenty-first century. The skill level of those currently involved in the outflow appears, in public and academically informed discourse, to be one of the most significant characteristics. If one of the distinguishing differences between the transatlantic movements of the late nineteenth and early twentieth century, and the intra-European migration of the 1960s and early 1970s was the "generalization to the entire country of the "emigration zone" (Almeida and Barreto 1970: 233), we believe that it is possible to hypothesize that, in addition to the features of the new migratory forms mentioned above, one of the distinctive elements of the current emigration movement is the generalization of the emigration experience to virtually all professional categories. In fact, while the emigration flow of the 1960s and 1970s was composed of predominantly poorly qualified people from the agricultural, industrial and domestic work sectors, with negligible emigration of skilled professionals, ${ }^{5}$ contemporary emigration, despite continuing to be mostly unskilled, seems, according to some mainly anecdotal information, to record an increase in the proportion of people with higher levels of qualification. Thus, for example, in 2014, $29.3 \%$ of Portuguese-born working in the UK had a tertiary degree (see chapter on the United Kingdom). In France, data on emigrants arrived between 2006 and 2011 show also a higher proportion of highly skilled when compared to emigrants arrived in previous periods (see chapter on France).

Docquier and Rapoport (2012) state in their study on the evolution of the "brain drain" in the past four decades, that Portugal was, in 2000, one of the European countries most affected by skilled emigration, with a skilled emigration rate of $19.5 \%$ of the skilled workforce in the country, or $13.1 \%$ if we limit the analysis to those who arrived in the country of destination aged 22 or over. ${ }^{6}$ Several media reports show that during the 2000s and early 2010s the emigration of highereducation graduates continued and intensified, increasingly including more professional groups (e.g. professions related to the health sector). Some of these professionals are recruited directly in Portugal and, while abroad, work in activity sectors directly related to their academic training. Others encounter some difficulties in transferring their qualifications to other labour markets and experience a labour market integration that is dissonant with their area of qualification, and as a result suffer downward mobility.

In terms of demographic characteristics, available information does not allow for a rigorous description of the age and sex structure of those who currently leave the country. Estimates of annual emigration published by the Portuguese Statistical Office show that most of those who temporarily or permanently left the country

\footnotetext{
${ }^{5}$ According to Baganha (1994) these professional groups had no rational motivation for migration since the existing labour market segmentation assured them a higher level of income.

${ }^{6}$ The first figure includes skilled immigrants regardless of whether they obtained their qualification in the country of origin or destination. The second figure uses information on the age at entry into the country of destination as a proxy for the country in which their qualification was acquired (assuming that those who entered aged 22 or more acquired their qualification in the country of origin) (Beine et al. 2006).
} 
were male (72\% in 2012) and in the active age group (in 2012, 57\% of migrants were between 20 and 39 years of age). Although differences between permanent and temporary migrants seem to be insignificant, it should be noted that the former have a younger age structure (with $55 \%$ between 20 and 34 as opposed to $40 \%$ for temporary migrants) and a higher proportion of women (29\% of permanent and $23 \%$ of temporary migrants).

\subsection{Economic Crisis, Unemployment and Changes in Migration Flows}

The majority of these outflows are a result of the negative growth in the Portuguese economy and the profound transformations of the Portuguese labour market brought about by the economic crisis. From 2009 to 2013 (with the exception of 2010) the Portuguese economy was marked by an unfavourable evolution. The average annual GDP growth rate in these 5 years was $-1.7 \%$ (or $2.6 \%$ if the year 2010 is not included in the calculus) (INE, database, various years). The annual decrease in the GDP, and the austerity measures had a profound impact on the Portuguese labour market. One of its biggest impacts is the massive increase in unemployment, and changing forms of employment, which affect some groups (e.g. youths, immigrants) in a more intense way. Workers aged 45 and over also form a disproportionate share of the hard-luck recession category, the long-term unemployed. In the aftermath of the 2008 financial and economic crisis, unemployment reached its highest level and socio-economic inequalities increased. Since the second half of 2008, the unemployment level started to rise sharply and is now well above $10 \%(16.3 \%$ in 2013 , whereas in 2008 it was $7.6 \%$ ). The young were particularly affected by unemployment, registering a $128 \%$ increase in their unemployment rate from 2008 to 2013 (Table 5.4).

Immigrants from non-EU member countries are also a social group particularly hit by unemployment in the aftermath of the 2008 financial and economic crisis. Their unemployment level is well above the national average and registered a more

Table 5.4 Unemployment rate by age group and gender 2008-2013, (\%)

\begin{tabular}{l|c|c|c|r|r|l|l}
\hline & 2007 & 2008 & 2009 & 2010 & 2011 & 2012 & 2013 \\
\hline $15-24$ & 16.7 & 16.7 & 20.3 & 22.8 & 30.3 & 37.9 & 38.1 \\
\hline $25-34$ & 9.8 & 8.7 & 11.0 & 12.8 & 14.1 & 18.1 & 19.0 \\
\hline $35-44$ & 6.7 & 6.7 & 8.4 & 9.8 & 11.0 & 13.3 & 14.4 \\
\hline 45 and more & 5.6 & 5.4 & 6.9 & 8.0 & 9.6 & 11.4 & 12.2 \\
\hline Total & 8.0 & 7.6 & 9.4 & 10.8 & 12.7 & 15.5 & 16.2 \\
\hline Males & 6.6 & 6.5 & 8.9 & 9.8 & 12.3 & 15.6 & 16.0 \\
\hline Females & 9.5 & 8.8 & 10.2 & 11.9 & 13.0 & 15.5 & 16.4 \\
\hline
\end{tabular}

Source: INE, Employment Survey, various years 
Table 5.5 Foreign population living legally in Portugal by selected nationality, 2001-2013

\begin{tabular}{l|l|l|l|l|l|l|l}
\hline Year & Total & Romania & Ukraine & Angola & $\begin{array}{l}\text { Cape } \\
\text { Verde }\end{array}$ & $\begin{array}{l}\text { Guinea } \\
\text { Bissau }\end{array}$ & Brazil \\
\hline 2001 & 129,473 & 508 & 203 & 22,751 & 49,845 & 17,791 & 23,422 \\
\hline 2002 & 238,929 & 615 & 299 & 24,782 & 52,223 & 19,227 & 24,762 \\
\hline 2003 & 249,995 & 764 & 525 & 25,616 & 53,434 & 20,041 & 26,508 \\
\hline 2004 & 263,322 & 1,219 & 1,551 & 26,517 & 54,788 & 20,511 & 28,730 \\
\hline 2005 & 274,631 & 1,564 & 2,120 & 27,533 & 55,608 & 20,935 & 31,500 \\
\hline 2006 & 332,137 & 5,446 & 22,846 & 28,856 & 57,369 & 21,170 & 42,319 \\
\hline 2007 & 401,612 & 17,200 & 34,240 & 30,431 & 61,110 & 22,174 & 55,665 \\
\hline 2008 & 436,020 & 26,425 & 52,472 & 27,307 & 50,887 & 23,842 & 106,704 \\
\hline 2009 & 451,742 & 32,457 & 52,253 & 26,292 & 48,417 & 22,404 & 115,882 \\
\hline 2010 & 443,055 & 36,830 & 49,487 & 23,233 & 43,510 & 19,304 & 119,195 \\
\hline 2011 & 434,708 & 39,312 & 48,010 & 21,329 & 43,475 & 18,131 & 111,295 \\
\hline 2012 & 417,142 & 35,216 & 44,074 & 20,366 & 42,857 & 17,759 & 105,622 \\
\hline 2013 & 401,320 & 34,204 & 41,091 & 20,177 & 42,401 & 17,846 & 92,120 \\
\hline
\end{tabular}

Source: 2001-2008: INE. Base de Dados [www.ine.pt]

2009-2013: SEF, Estatísticas [http://sefstat.sef.pt/relatorios.aspx]

marked increase within the last years than the national average, rising from $13.0 \%$ in 2007 to 30.4\% in 2013 (INE, Employment Survey, 2007 and 2013).

Due to these increases in the levels of unemployment, it is possible to state that the economic crisis was not only responsible for the recent increase in the outflow of Portuguese nationals (either by birth or by naturalization), it also impacted on the number of immigrants living in Portugal. Data on the evolution of the foreigners living in the country with a valid residence permit shows a continuous increase between 2001 and 2010 (marked by successive legalization opportunities for immigrants) and a noticeable decrease thereafter. This declining tendency became even more evident in 2013 when the total foreign population reached a number that was below the one they had just before the 2008 economic and financial crisis. This decrease is shared by the six major national groups present in the Portuguese territory (as we can see in Table 5.5). The data shows that, after an intense increase between 2001 and 2008, all nationalities experienced, albeit at a different pace, a clear decrease. We must emphasize the existence of a new citizenship law that allowed the naturalization of a very high number of legal foreign residents, which is part of the cause of this decrease.

\subsection{Migratory Patterns}

To the outflows of a more permanent character it is necessary to add a significant flow of temporary exits, sometimes of a circular character, which have intensified in recent decades as a result of the deepening of globalization, the EU's freedom of 
movement, the development of information and communication technologies, the emergence of low cost aviation companies in Europe, and the widespread growth of atypical forms of employment contract (visible, for example, through the extension of subcontracting processes to ever more areas of activity). Since the mid-1980s, these forms of temporary migration are a central characteristic of Portuguese outflows to different European countries. For example, in Switzerland the number of temporary entries of Portuguese citizens during the 1980s and 1990s was approximately 33,000, and 16,000 during the first 8 years of the twenty-first century (Marques 2008, 2009). After the end of the transition period fixed in the agreement on the free movement of labour signed between Switzerland and the European Union (2001-2007), the temporary entry of Portuguese citizens to Switzerland remained high (roughly 17,000 per year). Given that these are not permanent movements, it would be inaccurate to state that the overall number of temporary exits during the period under study corresponded to an equal number of migrants. Many of these outflows are carried out in successive years by the same migrants. They are, in fact, repeated movements of a single migrant and not new emigration movements performed by different migrants.

An undetermined number of these movements correspond to a circular migration movement that combines periods abroad (in one or several countries) with periods in Portugal. Some anecdotal information on the flow of Portuguese citizens to Angola or Mozambique (but also to other destinations of Portuguese multinational corporations), published in the national press, testify that this temporary migration also takes place in non-European contexts, although in these cases migration periods tend naturally to be of longer duration.

\subsubsection{The Case of Posted Workers}

A specific case of these temporary exits of Portuguese citizens is formed by posted workers, which developed as a result of Portugal's membership of the European Union (Ramos and Diogo 2003). This type of migratory outflow is substantially different from traditional forms of Portuguese emigration due to the fact that Portuguese companies acted as subcontractors of big European construction companies that used free movement within the European area to their advantage by promoting the mobility of Portuguese workers. This allowed Portuguese construction companies to benefit from the differential in labour costs that existed between Portuguese and other European construction workers (Baganha and Cavalheiro 2001).

In Germany, the number of posted Portuguese workers in 1997 was 21,919, representing $12.1 \%$ of all posted workers and $40.1 \%$ of posted workers from a European Union country (Worthmann 2003). Portuguese migrants were thus the largest group of posted workers from an EU member country working in Germany. According to some sources these figures did not account for the real number of Portuguese citizens involved in this type of migration flow, since they only refer to 
Table 5.6 Certificates and Portable Documents A1 issued in Portugal, by main destination countries (2007-2011)

\begin{tabular}{l|l|l|l|l|l}
\hline & 2007 & 2009 & 2010 & 2011 & Change 2009-2011 (\%) \\
\hline Germany & - & 4,858 & 5,175 & 4,770 & $-1.8 \%$ \\
\hline Spain & - & 23,854 & 18,968 & 12,762 & $-46.5 \%$ \\
\hline France & - & 12,694 & 17,191 & 18,502 & $45.8 \%$ \\
\hline Netherlands & - & 4,087 & 7,423 & 7,020 & $71.8 \%$ \\
\hline Total & 66,000 & 65,499 & 58,948 & 54,183 & -17.3 \\
\hline
\end{tabular}

Source: European Commission, 2011 and 2014

posted workers in a regular situation and therefore did not include around 35,000 Portuguese working as irregular posted workers (Gago and Vicente 2002: 212).

More recent data shows that in 2007 and 2009, Portuguese posted workers were, respectively, 66,048 and 65,499, and that in 2009, the main destination countries were Spain, France and Germany (European Commission 2011). ${ }^{7}$ From 1 May 2010

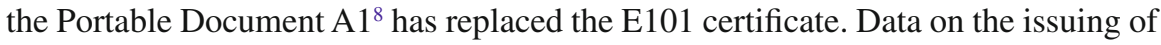
these documents for 2010 and 2011 shows a continuous declining trend of the number of documents issued (Table 5.6) that, in 2011, recorded the lowest value of the last 5 years $(54,183)$. This downward trend is clearly a result of the economic crisis in some of the former destination countries as we can see from a detailed analysis of the evolution of numbers of posted workers by main countries of destination.

This shows that the decline in posted workers to Spain accounts for the main reduction in the overall number of Portuguese posted workers between 2009 and 2011. A portion of this reduction was compensated by an increase in detachments to the Netherlands, and especially to France which, taken together, show an increase of detachments during the same time interval. Since the majority of the detachments head for the construction industry and public works (67.5\% in 2011) (European Commission 2012), it is conceivable that the crisis in this sector in Spain deflected the movement of posted workers to those national contexts in which the construction industry and public works were less affected by the economic crisis, or are in a process of recovery from the effects of this crisis.

Despite the mentioned limitations, data from detachments are indicative of mobility patterns and trends that have developed in recent years. They complement previously presented figures showing that opportunities for mobility within Europe have contributed (and continue to contribute) to the diversification of migratory opportunities for Portuguese citizens. These opportunities seem particularly relevant for workers in sectors that have been most affected by the current economic crisis (e.g. construction and public works).

\footnotetext{
${ }^{7}$ Data concerning posted workers does not necessarily correspond to a same number of migrants, as the same worker may have been assigned more than one E101 certificate (or, after 2010, a Portable Document A1).

${ }^{8}$ Council Regulation (EC) No 883/2004 regarding the coordination of social security systems (European Commission 2012).
} 
Taken together, the different types of temporary outflows to other member states of the European Union or to countries with which it has special relations (e.g. Switzerland), as well as more permanent emigration movements, have benefited from the possibilities of free movement within the European Union or the European Economic Area. The structuring of different destinations within this European migration system (and, from the mid-2000s onwards, within the Lusophone migratory system (Marques and Góis 2012; Baganha et al. 2005; Marques 2008)) allows for the diversification of migration opportunities, and consequently increases migrants' opportunities to react to short-term instabilities that arise in countries which are part of this migratory system (driven, for example, by economic, and /or political constraints). It can thus be said that one of the peculiarities of contemporary Portuguese emigration is a result of the multiplicity of migratory destinations, which are activated according to the set of opportunities that emerge and develop in different destination countries (Marques 2008, 2009).

Like the Portuguese outflows of the twentieth century (Baganha 1994), the pursuit of economic opportunities that are lacking in Portugal is one of the main reasons for current emigration flows. The rise in unemployment, the stagnation or even reduction in salaries, a lack of positive expectations regarding economic growth, etc., are powerful drivers of emigration flows. Although important, these conditions do not by themselves fully account for the intensity of the emigration flow. As in past emigration movements, the development and maintenance of present emigration is based, in different degrees and in variable configurations, on social structures that support migration. It is the positive evolution of these structures, consisting of family members, friends and acquaintances, which contribute to the selfsustainability of the migration process.

Two types of social network allow potential migrants to connect to existing opportunity structures in the country of origin and to access, after they arrival in the country of destination, resources that are important for their initial permanence in that country. It is thus possible to differentiate between 'internal migration networks' ${ }^{9}$ and 'external migration networks'. The first type of network helps to create, mainly in the country of origin, the necessary conditions to achieve emigration. It allows, for example, access to recruitment opportunities abroad, or knowledge of entities with potential relevance in accomplishing the migration process.

The second type of migratory network develops after leaving the country, and connects, in the destination country, recently arrived migrants with already established migrants (Marques 2008). These latter networks assume a different role in accordance with the national context in which they operate. They seem to be more relevant in more traditional emigration contexts (e.g. France and Switzerland) and play a less central role in recent emigration destinations (e.g. UK or Angola). So the recent emigration flow to France still maintains an initial connection with older and

\footnotetext{
${ }^{9}$ The notion of 'internal migration networks' is used to mean the relationship, in the country of origin, between migration candidates, migrants and non-migrants (at the individual or institutional level, like for example the notices of job opportunities in other countries made available by the Portuguese Employment Service offices).
} 
established emigration communities that contribute to the integration of newcomers in the labour market (often in companies owned by Portuguese or through replacing retiring Portuguese), and in the French housing market. Emigration to the UK has, at least partially, a lesser connection to previous emigration flows, and thus a greater propensity to integrate, either in new labour market sectors, or new geographical areas. ${ }^{10}$

\subsection{Policies and Political Debates on Emigration}

During most of Portugal's emigration history, political debates where framed by the contrasting objectives of controlling the migration flow, and to allow for the continuing emigration regarded both as an answer to overpopulation (from the perspective of the available employment opportunities), and as a source of remittances necessary for the industrialization and development of the country (among others, Baganha 2003; Pereira 2002, 2004, 2014). Until the national Constitution of 1976 the freedom to emigrate was constrained by the national interest (commonly defined as the interest of Portuguese elites). The inscription of the right to emigrate in the national Constitution (art. 44) occurred at a time when Portuguese emigration flows witnessed a deep transformation due to the end of the labour recruitment programmes of France and Germany.

The country's accession to the European Community in 1986 brought about a certain invisibility of migratory outflows and concurrently a change in the political elites' attitudes towards emigration. The exit of Portuguese citizens became an "embarrassing fact" (Baganha et al. 2005) that was in contradiction with the country's position among the most developed countries of Europe. The denial or, at least, the underestimation of on-going outflows went along, as said previously, with increasing immigration flows that were much more acceptable to the development discourse of the political elite of that time. Thus, in the last decades, emigration was subjected to a continuous process of deflation whereby existing outflows were not incorporated in the political discourses and in scientific practices.

Political debates and initiatives on emigration during this period were mainly on policies aimed at promoting the emigrant's engagement with their country of origin (Marques and Góis 2013). Only after the recent upsurge in the outflow of Portuguese citizens has it been possible to observe an increase in the discourses (political, scientific, and by the media) on emigration flows.

Due to the incipient expansion of current emigration, these discourses are however of a fragmentary nature and frequently not integrated in an overall strategy on emigration flows and emigration communities abroad. In order to analyse the

\footnotetext{
${ }^{10}$ In 2001, $61.5 \%$ of all Portuguese-born in England lived in the London region. Ten years later this percentage decreased to $47.8 \%$, while all other regions in England reported an increase of Portuguese-born (most significant in the East and South East regions of England). (Data from UK Census 2001 and 2011, available at http://infuse.mimas.ac.uk/).
} 
quantitative evolution and the changes in the formal political debates on emigration, an analysis of parliamentary debates of the last 8 years (from 2006 to 2013) ${ }^{11}$ was conducted. ${ }^{12}$ The objective was to discover if, as a result of the economic crisis, emigration became a salient theme in parliamentary debates and if there was a substantial change in the categories that usually frame the political debate on emigration. ${ }^{13}$

The quantitative analysis shows, notwithstanding some important fluctuations, an overall increase in references to emigration/emigrants over the last 8 years, from 37 references in 2006 to 85 in 2013. This increase is evident both in references to emigrants and to emigration, and is particularly noticeable since 2011 (the year that marked the beginning of the EU/IMF financial assistance program). This increase in references to emigration/emigrants does not however evidence a clear and unquestionable renewed interest in emigration: from the 503 analysed texts in which a reference to emigration/emigrants was made, $42.9 \%$ refer to issues that are not directly linked to emigration, such as proposals on the creation of municipalities, laws on immigration, or in reports on the participation of deputies in external activities. And $21.3 \%$ of the references are mainly related to past emigration flows and to the Portuguese community abroad (questions on associations, on the Portuguese media abroad, on the teaching of Portuguese language abroad, on descendants of Portuguese citizens, on the Council of Portuguese Communities, ${ }^{14}$ on fiscal aspects, and on citizenship and political participation of emigrants). ${ }^{15}$ Debates on current emigration cover thus 'only' $18.4 \%$ of the analysed documents and even these are

\footnotetext{
${ }^{11}$ Two reasons justified the selection of the year 2006 to start our study. First, the year 2006 corresponded to a legislative period which was not influenced by a parliamentary electoral campaign. Second, and more important, during this year the economic crisis was not yet present in the political and media discourse, so allowing for a comparison with the following years which were strongly affected by the crisis.

${ }^{12}$ For this study 503 texts with references to emigration and/or emigrants were analysed. The total number of documents with references to these two themes was 553, but since 50 documents could not be retrieved from the database of the National Parliament they were excluded from our analysis.

${ }^{13}$ It is important to note that this study of parliamentary debates was not guided by the intention of conducting a discourse analysis, but by the aim to identify prominent emigrant related themes that figured in the daily-transcribed parliamentary debates. Therefore an inductive content analysis was conducted and the relevant passages of the diaries where coded according to a coding scheme that emerged from the analysed texts. We have used 30 categories and 59 sub-categories to map the relevance of Portuguese emigration related subjects for the period 2006-2013 in the interventions of the Portuguese MPs and government members. This research technique allowed for the identification of the most relevant categories and the measurement of the frequency of references in each category.

${ }^{14}$ This Council was created in 1980. It has a consultative role in advising the government in matters related to emigration and Portuguese communities abroad (Marques and Góis 2013).

${ }^{15}$ This does not mean that some of these issues could not also refer to new emigrants and recent emigration flows. But the context in which they were discussed refers exclusively to Portuguese communities that resulted from past emigration flows.
} 
not exclusively on present emigration flows. ${ }^{16}$ As could be expected the main themes discussed in regard to present emigration refer to the growth of the emigration flow, the measures adopted by the State to assist these new emigrants (mainly through the development of the network of consular posts), questions of integration, and visa policies of non-EU receiving countries (e.g. Angola). The debated issues frequently did not lead to concrete measures or policies towards present day migrants. An exception are measures that intend to facilitate circulation between Portugal and non-EU countries ${ }^{17}$ and measures that albeit not directed to current emigrants impact on their engagement with the country of origin (measures on the reduction of consular workers or on the availability of Portuguese Language and Culture courses abroad). Most of existent engagement policies were created in the aftermath of Portuguese emigration of the 1960s and early 1970s. They are, therefore, marked both by the characteristics of these emigrants and by the objective to expand post1974 democratic participation to Portuguese citizens living abroad. Thus extraterritorial political participation was introduced in 1976, the Council of Portuguese Communities Abroad was created in 1980, and Portuguese Language and Culture courses where introduced in 1973/1974 (Marques and Góis 2013; Aguiar 2009, 1987).

A closer look at the debates on current emigration flows reveals that most of them are made either in a discussion on the economic crisis (and used as an 'instrument' to question the austerity policies adopted by the government), or on questions related to the integration of these emigrants (or their children) in the destination country.

The instrumental use of emigration is particularly evident in the discourses of the opposition parties that blame the government for the increasing outflows, as can be seen in the following excerpts:

Given this dramatic reality, the government cannot deny (...) that the emigration of Portuguese citizens has increased with the growth of economic difficulties in our country (Communist Party, Diary of the National Parliament, 25/05/2013).

Many thousands of young people, including the most qualified, are pushed to the inevitability of emigration by a government with no vision for the future, which is unable to open the horizon of hope for them (Socialist Party, Diary of the National Parliament, 23/03/2013).

The issue of the brain drain to which the last citation refers is a salient theme both in the parliamentary debates and in the media. In both cases different groups (politicians and journalists) use anecdotal evidence of the outflow of highly skilled Portuguese citizens either to illustrate the negative impact of this emigration flow on the future of Portuguese economy, or to illustrate the most important differences between current Portuguese emigration vis-à-vis past emigration flows. Although the most salient issue (together with the general increase in outflows) in public

\footnotetext{
${ }^{16}$ The remaining $17.6 \%$ of the analysed documents make references to emigration/emigrants not related to this theme (for example during the discussion of the annual State budget, or during debates on the European Union.)

${ }^{17}$ For example, the bilateral agreement between Portugal and Angola on visa facilitation.
} 
debates on current emigration is the issue of highly skilled migration (and on the brain drain usually associated with it), this has not lead to significant policy responses aimed at this component of the current migration flows, or at current migration in general. Most of the policies adopted by the Portuguese State (e.g. the Council of Portuguese Communities) continue to be based on an image of emigration from the 1960s and early 1970s. Support and network structures directed at highly skilled migrants are a result of the efforts of this type of migrant in the destination countries, and receive after their creation a variable amount of support from the Portuguese State (mainly through the Portuguese Embassies). ${ }^{18}$

\subsection{Final Remarks}

Emigration is an integral part of Portuguese society that in the last couple of years has gained a new momentum. Like previous outflows the current wave has been shaped by the existing institutional and political framework, by the development of the conditions for mobility and by the functioning of migratory networks. Distinct features of present day migration flows are the diversification of destination countries, the participation of a significant proportion of highly-skilled in the emigratory flow, and the coexistence between old and new forms of migration. These new forms of migration are mainly the result of the legal and institutional framework created by the accession of Portugal to the European Union in the mid 1980s, and thus take advantage of the opportunities for circulation that exist within the European area. During the early years of this century, the Portuguese migratory destinations have become more diversified, complementing European destinations with the intensification of outflows to other countries, especially to Portuguese-speaking countries (above all to Brazil and Angola).

A substantial part of the current migratory movement is motivated by the country's economic constraints, and in particular by the continued rise in unemployment, and by the existence of economic benefits in other countries. The links between job opportunities abroad and potential migrants are, like in past migration flows, promoted by the activation or, as is the case of the most recent destination countries, by the construction and consolidation of migratory networks.

The revival of Portuguese emigration after the 2008 financial and economic crisis did not lead to concrete and strategic policies directed towards the new reality of emigration, as is evident from the analysis of the parliamentary debates described in the second part of the chapter. Policies continue to privilege the engagement of emigrants with their country of origin and most of them are based on the image of earlier emigration flows (Marques and Góis 2013). As described in the first part of this text, contemporary Portuguese emigration exhibits important differences from previous emigration flows, making it necessary to study the appropriateness of these

\footnotetext{
${ }^{18}$ Examples of these networks are the PARSUK - Portuguese Association of Researchers and Students in the United Kingdom and the Association Agrafer, France.
} 
policies for the current outflow (a study that it is not possible to pursue in this place). Although present day emigration continues to be mainly composed of less qualified workers, it remains to be seen if existing policies also appeal to more qualified migrants and to migrants who have a more temporary or even a circular migration trajectory.

\section{References}

Aguiar, M. M. (1987). Política de Emigração e Comunidades Portuguesas. Porto: Secretaria de Estado das Comunidades Portuguesas/Centro de Estudos.

Aguiar, M. M. (2009). O Conselho das Comunidades e a Representação dos Emigrantes. Revista Migrações - Número Temático Migrações entre Portugal e América Latina (5), 257-262.

Almeida, C., \& Barreto, A. (1970). Capitalismo e Emigração em Portugal. Lisboa: Prelo Editora. Arroteia, J. (1983). A Emigração Portuguesa. Suas Origens e Distribuição (Colecção Biblioteca Breve). Lisboa: Instituto de Cultura e Língua Portuguesa (Colecção Biblioteca Breve).

Baganha, M. I. (1993). Principais Características e Tendências da Emigração Portuguesa. In Estruturas Sociais e Desenvolvimento-Actas do II Congresso Português de Sociologia (Vol. I, pp. 819-835). Lisboa: Fragmentos.

Baganha, M. I. (1994). As correntes emigratórias portuguesas no século XX e o seu impacto na economia nacional. Análise Social, XXIX(128), 959-980.

Baganha, M. I. (2003). From closed to open doors: Portuguese emigration under the Corporatist Regime. E-Journal of Portuguese History, 1(1), 1-16.

Baganha, M. I., \& Cavalheiro, L. (2001). Uma europeização diferenciada: o sector da construção civil e obras públicas. In J. Reis \& M. I. Baganha (Eds.), A economia em curso: contextos e mobilidades (pp. 63-86). Porto: Edições Afrontamento.

Baganha, M. I., \& Peixoto, J. (1997). Trends in the 90's: The Portuguese migratory experience. In M. I. Baganha (Ed.), Immigration in Southern Europe (pp. 15-40). Oeiras: Celta.

Baganha, M. I., Góis, P., \& Pereira, P. T. (2005). International migration from and to Portugal: What do we know and where are we going? In K. Zimmermann (Ed.), European migration: What do we know? (pp. 415-457). Oxford: Oxford University Press.

Beine, M., Docquier, F., \& Rapoport, H. (2006). Measuring international skilled migration: new estimates controlling for age of entry (Policy Research Discussion Paper, World Bank). http:// siteresources.worldbank.org/INTRES/Resources/469232-1107449512766/ MeasuringInternationalMigration_paper.pdf

Branco, J. P. (2013). Implantação geográfica dos portugueses em França: evolução observada entre 1990 e 2009. Sociologia, Revista da Faculdade de Letras da Universidade do Porto, XXVI, 209-226.

Docquier, F., \& Rapoport, H. (2012). Globalization, brain drain, and development. Journal of Economic Literature, 50(3), 681-730. doi:10.1257/jel.50.3.681.

European Commission. (2011). Posting of workers in the European Union and EFTA countries: Report on E101 certificates issued in 2008 and 2009. DG Employment, Social Affairs \& Inclusion.

European Commission. (2012). Posting of workers in the European Union and EFTA countries: Report on A1 portable documents issued in 2010 and 2011. DG Employment, Social Affairs \& Inclusion.

Gago, C., \& Vicente, T. (2002). Alemanha. In M. I. Baganha, J. Ferrão, \& J. Malheiros (Eds.), Os Movimentos Migratórios Externos e a Sua Incidência no Mercado de Trabalho em Portugal (pp. 177-224). Lisboa: Observatório do Emprego e Formação Profissional.

Godinho, V. M. (1978). L'émigration portugaise: XV-XXe siècles: une constante structurale et les réponses aux changements du monde. Revista de História Económica e Social, I, 5-32. 
Marques, J. C. (2008). Os Portugueses na Suíça: Migrantes Europeus. Lisboa: Imprensa de Ciências Sociais.

Marques, J. C. (2009). 'E Continuam a Partir': As Migrações Portuguesas Contemporâneas. Ler História, 56, 27-44.

Marques, J. C., \& Góis, P. (2012). A evolução do sistema migratório lusófono. Uma análise a partir da imigração e emigração portuguesa. Revista Internacional de Língua Portuguesa, 24, 213-231.

Marques, J. C., \& Góis, P. (2013). Portuguese emigrants and the State: An ambivalent relationship. In M. Collyer (Ed.), Emigration Nations: The ideologies and policies of emigrant engagement (pp. 252-276). Houndmills: Palgrave Macmillan.

Paiva, A. (1985). Portugal e a Europa: o fim de um ciclo migratório. Lisboa: Instituto de Estudos para o Desenvolvimento.

Peixoto, J. (1993). A emigração portuguesa a partir de 1980: Factos estatísticos e modalidades de evolução. Estudos Demográficos, 31, 35-74.

Pereira, M. H. (2002). A política portuguesa de emigração: 1850-1930. São Paulo: EDUSC; Instituto Camões.

Pereira, V. (2004). La politique d'émigration de l'Estado Novo entre 1958 et 1974. Cahiers de l'Urmis - Portugais de France, immigrés et citoyens d'Europe, 9, 15-33.

Pereira, V. (2014). A Ditadura de Salazar e a Emigração. O Estado Português e os seus Emigrantes em França (1957-1974). Lisboa: Temas e Debates - Círculo de Leitores.

Pires, R. P., Pereira, C., Azevedo, J., \& Ribeiro, A. C. (2014). Emigração Portuguesa. Relatório Estatístico, 2014. Lisboa: Observatório da Emigração e Rede Migra, Instituto Universitário de Lisboa (ISCTE-IUL), CIES-IUL e DGACCP.

Ramos, M. C., \& Diogo, H. (2003). Le Portugal, pays relais de la migration en Europe. Migrations Etudes $\left(\mathrm{n}^{\circ} 116\right)$.

Serrão, J. (1982). A Emigração Portuguesa. Lisboa: Livros Horizonte ( $4^{a}$ ed.).

Worthmann, G. (2003). Nationale Autonomie trotz Europäisierung: Probleme der Arbeitsmarktregulierung und Veränderungen der industriellen Beziehungen in der deutschen Bauwirtschaft. München: Rainer Hampp Verlag.

Open Access This chapter is licensed under the terms of the Creative Commons AttributionNonCommercial 2.5 License (http://creativecommons.org/licenses/by-nc/2.5/), which permits any noncommercial use, sharing, adaptation, distribution and reproduction in any medium or format, as long as you give appropriate credit to the original author(s) and the source, provide a link to the Creative Commons license and indicate if changes were made.

The images or other third party material in this chapter are included in the chapter's Creative Commons license, unless indicated otherwise in a credit line to the material. If material is not included in the chapter's Creative Commons license and your intended use is not permitted by statutory regulation or exceeds the permitted use, you will need to obtain permission directly from the copyright holder.

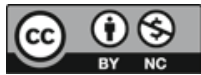




\title{
Chapter 6 \\ Is Spain Becoming a Country of Emigration Again? Data Evidence and Public Responses
}

\author{
Anastasia Bermudez and Elisa Brey
}

\subsection{Introduction}

The global financial and economic crisis that erupted at the end of 2007 has had a dramatic impact in the Southern EU member states, including Spain. Some of these countries despite having a history of emigration had lately become major attraction poles for immigrants as their economies expanded and demanded new workers. However, as the crisis deepened, labour markets contracted severely with two consequences: growing unemployment and increased emigration (as well as reduced immigration). Being such a recent phenomenon, there is still a lack of detailed knowledge about these outflows, something that has contributed to polarize opinions on the causes and consequences.

In the case of Spain, some public discourses portray this new emigration as limited and the result mainly of immigrants returning to their countries of origin (or re-emigrating) as labour opportunities decrease. Since one of the main focuses of migration policy post-crisis has been return migration, this could be perceived as positive. Equally, the emigration of young, qualified natives is seen as mostly the choice of individuals in search of new experiences or as part of a globalising labour force, rather than as a negative result of the crisis. By contrast, others point out that official data underrepresents the true extent of current emigration and its main characteristics. As well as arguing that the outflows are larger than assumed and the outcome of poor job opportunities and reduced social expenditure, critics point out

\author{
A. Bermudez ( $\triangle)$ \\ Department of Social Anthropology, Universidad de Sevilla, Sevilla, Spain \\ CEDEM, Université de Liège, Liège, Belgium \\ e-mail: abermudez1@us.es \\ E. Brey \\ CEDEM, Université de Liège, Liège, Belgium
}

GEMI, Universidad Complutense de Madrid, Madrid, Spain 
that emigration is especially affecting the young and highly educated, which could have serious economic and demographic effects.

The following sections delve further into these questions, with the aims of clarifying what the available statistics say about recent emigration from Spain and of analysing the policy and public responses. To contextualize the current situation, we start with a description of key economic and migration data and then look into main destinations and the sociodemographics of recent outflows, to finish with a critical appraisal of policies and public debates.

\subsection{The Relationship Between Economics and Migration: The Impact of the Crisis}

From the mid-1990s, Spain enjoyed a period of strong and sustained economic growth reflected in the expansion of its labour market. Employment rates climbed gradually to reach a peak of $69.5 \%$ in 2007, just below the EU-28 average. At the same time, and despite the enlargement of the workforce (Alonso Pérez and Furio Blasco 2010), unemployment declined to an all-time low of $8.2 \%$, slightly above the EU value (Labour Force Survey, LFS, Eurostat). However, the present crisis put an end to this bonanza in a much more dramatic way than the recessions of the mid1970 s and early 1990s, both in terms of economic deceleration and job losses (Ortega and Peñalosa 2012).

Although the crisis has affected labour markets globally, the impact in Spain has proven how unstable the previous period of prosperity was. After GDP growth rates of around $4 \%$ the previous 3 years, since the crisis started the economy has contracted (by $-3.6 \%$ in 2009) or barely grown (by $1.4 \%$ in 2014). As a result, annual employment rates have fallen to the levels registered at the beginning of the twentyfirst century, while unemployment reached $24.5 \%$ in 2014 (more than 14 percentage points above the EU average). In addition, over $29 \%$ of the population in Spain is considered to be at risk of poverty or social exclusion (up from $23 \%$ in 2007), while income inequality has augmented. The impact of all this has been uneven. Male unemployment rates more than tripled from 2007 to 2014, although women continue to record a slightly higher figure (Eurostat data). But it seems to be young people who have seen their chances of entering or remaining in the job market most affected (OPAM 2012). By 2014, among the group 16-19 years old, over two-thirds of the economically active were unemployed, while more than half of those aged 20-24 were in the same situation (see Table 6.1). Although younger people have traditionally been more exposed to joblessness, the impact of the current crisis has generated concerns about the loss of human capital due to inactivity or emigration (González Enríquez and Martínez Romera 2014; Navarrete Moreno 2013).

Educational attainment also influences labour market opportunities, with unemployment hitting hardest those with the lowest levels of formal education. Still, at the end of $2014,14.3 \%$ of people with higher education could not find a job. The 
Table 6.1 Annual unemployment rates (\%) by age group in Spain, 2007-2014

\begin{tabular}{l|r|r|l|l|l|l|l|l}
\hline & 2007 & 2008 & 2009 & 2010 & 2011 & 2012 & 2013 & 2014 \\
\hline $16-19$ & 28.7 & 39.4 & 55.2 & 61.3 & 64.0 & 72.6 & 74.0 & 68.6 \\
\hline $20-24$ & 15.0 & 20.2 & 33.3 & 36.9 & 42.3 & 48.9 & 51.8 & 50.3 \\
\hline $25-29$ & 9.0 & 13.3 & 21.7 & 24.7 & 26.3 & 31.5 & 33.3 & 30.3 \\
\hline $30-44$ & 7.0 & 9.9 & 16.2 & 18.2 & 19.7 & 22.7 & 23.7 & 22.0 \\
\hline $45-54$ & 6.3 & 8.4 & 13.4 & 15.3 & 17.1 & 20.5 & 22.2 & 21.2 \\
\hline 55 and more & 5.7 & 7.1 & 11.5 & 13.5 & 14.4 & 17.3 & 19.4 & 19.3 \\
\hline
\end{tabular}

Source: Encuesta de Población Activa (EPA), Instituto Nacional de Estadística (INE)

data also shows that migrants have been particularly affected. The unemployment rate for the foreign born in 2014 was $33.3 \%$, more than 10 percentage points above the value for those born in Spain (Eurostat). For some groups, such as migrants from outside Europe and Latin America, a category which mainly comprises African nationals (in particular Moroccans), unemployment is even higher (Oliver Alonso 2013).

Based on this, as a result of the crisis one would expect a reduction of labour immigration and increased outflows in the form of both return migration and native emigration. The Spanish immigration boom was inextricably linked to the economic bonanza. Up until the 1970s, Spain was mainly a country of emigration, receiving hardly any immigrants (Romero Valiente 2003). As emigration started to dwindle immigration took off, growing exponentially with the arrival of the new century. Until approximately 2009, Spain received an average of almost half a million foreign-born individuals annually, thus becoming the second-largest recipient of immigrants in absolute terms in the OECD after the United States (Arango 2013).

Population censuses show the number of foreign nationals in the country to have risen from some 350,000 in 1981 to close to 5.3 million in 2011. Data from the municipal population registries (Padrón municipal) also show how the number of foreign nationals in Spain increased steadily until 2008, when it reached 5.6 million ( $12 \%$ of the total population). However, by the end of 2014 the foreign population had fallen to 4.7 million. Although this can partly be ascribed to naturalisations, the foreign-born population has also shrunk (from 6.7 million in 2011 to just above 6.1 million) (INE). ${ }^{1}$ Thus, stagnation and decline has been due both to a reduction in immigration and an acceleration of emigration, which has turned the migratory balance negative since 2010. Nevertheless, there is controversy about the significance and characteristics of these new outflows.

\footnotetext{
${ }^{1}$ Provisional data by 1 st January 2015. The Padrón is the most used source in studies of migration in Spain but it has some disadvantages. It can overestimate the number of foreign nationals residing in the country and underestimate emigration flows, since there are no incentives for people to deregister once they leave the country. This could explain the discrepancy between the number of foreign residents estimated by the 2011 Census and those registered by the Padrón in the same year (5.7 million) (OPAM 2013).
} 


\subsection{Recent Emigration: How Many Are Leaving, Where and Who Are They?}

Emigration from Spain has never ceased but it was very much reduced after the 1970s (Valero-Matas et al. 2010). Nevertheless, the number of 'deregistrations'2 (Estadística de Variaciones Residenciales, EVR) from the Padrón from people moving abroad has been increasing steadily over the last decade, with annual figures almost doubling from 2007 to 2014. The external migration statistics (Estadística de Migraciones/Migraciones Exteriores) also show outflows to have risen (see Table 6.2). ${ }^{3}$ In addition, the Padrón for Spanish nationals abroad (PERE) sets the number of this population at almost 2.2 million. This figure does not cover the emigration of foreign nationals from Spain, while it includes people who have acquired Spanish nationality abroad because of their parents or as a result of the Ley de la Memoria Histórica (Law of Historical Memory, which allows descendants of previous emigrants to naturalize) (González Enríquez 2013; Izquierdo and Chao 2014). Of the 174,571 'new registrations' recorded in the PERE by 1st January 2015, almost two-thirds belonged to people born $\operatorname{abroad}^{4}$ (INE).

Based on the above trends, some have argued that the current phenomenon of Spanish emigration abroad is not as preoccupant as portrayed (González Enríquez 2013). Figures suggest that despite the socioeconomic conditions in the country, emigration has not become the main response to the crisis. Given the high unemployment rates and increases in poverty and social exclusion (Llano Ortíz 2015), this could be seen as surprising.

However, there are nuances to this argument. The first is that official numbers could underestimate actual emigration. As already mentioned, there are hardly any incentives for people moving abroad to deregister from the Padrón in Spain, and in the case of Spanish nationals register at consulates. González Enríquez (2014a) argues that following recent reforms, emigrants are even less likely to register abroad and risk losing their right to healthcare in Spain. This seems to be the case especially for EU flows. Following a survey of 2,183 Spanish adults who had emigrated during 2008-2013, Romero Valiente and Hidalgo-Capitán (2014) estimate their rate of under registration in the PERE to be around $50 \%$, climbing to $60 \%$ in the case of intra-EU mobility and $75 \%$ for the United Kingdom. This is why

\footnotetext{
${ }^{2}$ Deregistrations (bajas in Spanish) refer to people who are removed from a particular municipal population registry (Padrón municipal) because they move to another municipality (within Spain or abroad) or for other reasons (death, incorrect registration, expiry date).

${ }^{3}$ Both the EVR and the Estadística de Migraciones use data from the Padrón but while the first simply reports registrations (altas) and deregistrations (bajas), the second employs a more sophisticated methodology to try and be more accurate (it estimates the date of emigration abroad, uses a coefficient of expansion of observed flows, adjusts the information in the Padrón to its own definition of migration, etc.) (INE 2014). As a result, the data from both sources does not necessarily coincide.

${ }^{4}$ These could include nationalized migrants who have returned or re-emigrated as well as those people who have acquired Spanish nationality abroad.
} 


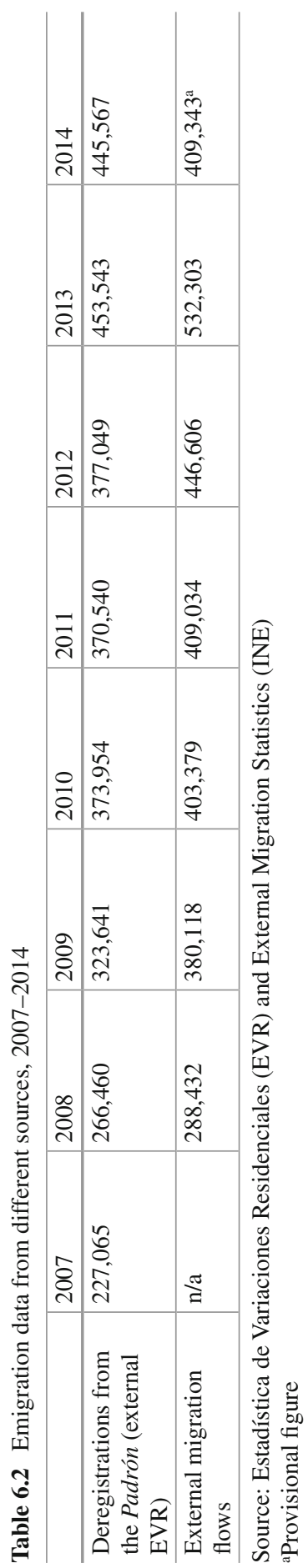


González Ferrer (2013a), using official statistics from countries of origin and main destinations, believes that the number of Spanish emigrants since 2008 could be closer to 700,000. Nevertheless, Romero Valiente and Hidalgo-Capitán (2014) argue that data from destination countries, especially in the EU, could also overestimate the number of Spanish migrants (due mainly to the temporary nature of some migratory movements) (see also Aparicio Gómez 2014).

Secondly, it is important to take into account that emigration is not necessarily available to everyone, and especially to those in the direst of circumstances or with the lowest qualifications. Thus we turn our attention now to who are these new emigrants and where are they going. Despite the shortcomings identified, official statistics can still offer some clues.

According to the PERE, of the just over two million registered Spaniards abroad, almost two-thirds resided in the Americas, mainly in Argentina, followed by Venezuela, Brazil, Cuba, Mexico and the United States. The second largest contingent is in Europe, especially France, Germany, Switzerland and the United Kingdom (INE). These numbers include those who emigrated long ago and their descendants. They reflect the fact that past emigration from Spain was directed mainly towards Latin America, and from the 1960s increasingly to other Western European countries (Romero Valiente 2003; Valero-Matas et al. 2010). These flows were later reversed following first return migration, and later the movement of foreign nationals from Europe (in large part retired people) as well as Latin America and Africa (mainly labour migration) to Spain. Data from the EVR (reflecting deregistrations from the Padrón due to moves abroad ${ }^{5}$ ) as well as new registrations in the PERE, show that recent Spanish emigration has largely followed the same routes (see Table 6.3).

Within Europe, it is recipients of past Spanish emigration, such as Germany, France and Switzerland, as well as the United Kingdom, that register the largest absolute and relative increases in deregistrations from the Padrón. Although there is also a large number of deregistrations linked to Romania, one of the main countries of origin of recent immigration into Spain, in relative terms the increase over the crisis period has been minimal. In Latin America, two of the countries with the highest immigrant presence in Spain, Ecuador and Colombia, have also seen the largest relative increases in people moving there, while figures from Africa and Asia are more modest. Still, the number of deregistrations allocated to Morocco is significant, which could be due largely to return migration.

Data from some of these destinations also suggest that emigration could be higher than what the Spanish statistics reflect, although as mentioned before such figures could be inflated. In the United Kingdom, Spanish applicants for a national insurance number (essential to be able to work) have increased significantly, reaching around 50,000 in 2014 (National Statistics 2015). González-Ferrer (2013a)

\footnotetext{
${ }^{5}$ These figures are just an illustration, since the EVR only has information about country of destination for $26 \%$ of the deregistrations owed to moves abroad. The rest includes cases where the country of destination is not known as well as automatic deregistrations (since 2006 foreign nationals from third countries without permanent residence must renew their registration every 2 years, failing that they are automatically deregistered).
} 
Table 6.3 Deregistrations from the Padrón in Spain as a result of moves abroad and new registrations in the PERE in selected destination countries, 2008-2014

\begin{tabular}{l|c|c|c}
\hline & $\begin{array}{l}\text { Deregistrations in Spain } \\
2008-2014\end{array}$ & $\begin{array}{l}\text { Relative increase } \\
2008 / 2014\end{array}$ & $\begin{array}{l}\text { New PERE } \\
\text { registrations 2014 }\end{array}$ \\
\hline EUROPE & $\mathbf{3 2 0 , 3 7 4}$ & $\mathbf{8 0} \%$ & $\mathbf{5 7 , 2 0 9}$ \\
\hline United Kingdom & 59,425 & $191 \%$ & 12,731 \\
\hline France & 45,977 & $132 \%$ & 13,751 \\
\hline Germany & 45,036 & $163 \%$ & 10,334 \\
\hline Romania & 38,602 & $4 \%$ & 450 \\
\hline Switzerland & 19,187 & $116 \%$ & 5,529 \\
\hline Belgium & 17,837 & $40 \%$ & 4,106 \\
\hline Netherlands & 12,451 & $55 \%$ & 1,728 \\
\hline AMERICAS & $\mathbf{2 3 2 , 2 5 0}$ & $\mathbf{7 8} \%$ & $\mathbf{1 0 7 , 5 9 4}$ \\
\hline Ecuador & 49,852 & $512 \%$ & 10,943 \\
\hline United States & 34,240 & $71 \%$ & 11,626 \\
\hline Argentina & 24,834 & $-11 \%$ & 21,825 \\
\hline Colombia & 24,242 & $196 \%$ & 5,806 \\
\hline Bolivia & 21,815 & $-9 \%$ & 2,387 \\
\hline Venezuela & 19,483 & $52 \%$ & 8,527 \\
\hline Brazil & 17,358 & $0 \%$ & 7,252 \\
\hline AFRICA & $\mathbf{4 1 , 6 4 9}$ & $\mathbf{6} \%$ & $\mathbf{3 , 3 4 2}$ \\
\hline Morocco & 26,464 & $-1 \%$ & 1,508 \\
\hline ASIA & $\mathbf{2 7 , 9 9 0}$ & $\mathbf{5 6} \%$ & $\mathbf{5 , 2 4 7}$ \\
\hline China & 9,216 & $24 \%$ & 945 \\
\hline
\end{tabular}

Source: Padrón Municipal and PERE (INE)

also shows that non-Germans coming from Spain into Germany increased from some 5,000 in 2008 to 30,000 in 2012. According to official Belgian data, 17,354 Spaniards registered in the country only in the first 4 years of the crisis (DEMO 2013). In the case of flows directed towards Latin America, it is assumed that a large part of these movements are of return migrants (Aparicio Gómez 2014; GonzálezFerrer 2013b).

If recent emigration reflected the groups worst affected by rising unemployment, it would be expected that a large percentage of emigrants would be young, foreign nationals, men and with lower education. However, these are not necessarily the groups with the greater access to moving abroad. Once again, despite its deficiencies, available data provide some evidence. First of all, there seems to be differences between recent emigration to Europe (or the United States) and to Latin America and Morocco. While in the case of the former the latest figures indicate that a majority of emigrants are Spanish nationals born in Spain, in the latter it seems to relate primarily to return migration of nationalized migrants and foreign nationals (see Table 6.4). Spaniards born abroad also represent a significant proportion of those migrating to other European countries, which implies that re-emigration flows are important. Secondly, in absolute numbers, the largest age group in the case of most destinations is the 25-34 years old, with almost equilibrium or a slight majority of men in general. 
Table 6.4 Deregistration from the Padrón in Spain of people moving to main destinations abroad, 2014

\begin{tabular}{l|l|l|l|l|l}
\hline & Men & $\begin{array}{l}\text { Main age } \\
\text { group }\end{array}$ & $\begin{array}{l}\text { Spaniards born } \\
\text { in Spain }\end{array}$ & $\begin{array}{l}\text { Spaniards born } \\
\text { abroad }\end{array}$ & $\begin{array}{l}\text { Foreign } \\
\text { nationals }\end{array}$ \\
\hline Germany & $50.5 \%$ & $25-34$ & $54.2 \%$ & $18.7 \%$ & $27.2 \%$ \\
\hline France & $52.6 \%$ & $25-34$ & $54.2 \%$ & $27.2 \%$ & $18.6 \%$ \\
\hline United Kingdom & $49.5 \%$ & $25-34$ & $46.6 \%$ & $16.7 \%$ & $36.7 \%$ \\
\hline Belgium & $52.0 \%$ & $0-15$ & $47.7 \%$ & $25.9 \%$ & $26.5 \%$ \\
\hline Switzerland & $53.1 \%$ & $25-34$ & $64.6 \%$ & $23.4 \%$ & $12.0 \%$ \\
\hline Morocco & $71.3 \%$ & $25-34$ & $18.0 \%$ & $08.7 \%$ & $73.3 \%$ \\
\hline Argentina & $51.9 \%$ & $25-34$ & $31.5 \%$ & $37.8 \%$ & $30.7 \%$ \\
\hline Bolivia & $50.3 \%$ & $0-15$ & $20.4 \%$ & $29.9 \%$ & $49.8 \%$ \\
\hline Colombia & $50.4 \%$ & $0-15$ & $25.2 \%$ & $42.7 \%$ & $32.1 \%$ \\
\hline Ecuador & $50.3 \%$ & $0-15$ & $33.0 \%$ & $53.0 \%$ & $24.4 \%$ \\
\hline United States & $49.5 \%$ & $25-34$ & $58.1 \%$ & $30.9 \%$ & $11.0 \%$ \\
\hline S & & & &
\end{tabular}

Source: Estadística de Variaciones Residenciales (EVR)

This picture can be contrasted with the few studies conducted on the topic until now. Some suggest that a large proportion of recent emigrants from Spain are foreigners or nationalized migrants, male and up to 45 years in age (González-Ferrer 2013a; González Enríquez 2013; González Enríquez and Martínez Romera 2014). A recent investigation focusing on native Spaniards (born in Spain with both parents born in the country) supports the idea that a majority of recent emigrants are not among the youngest cohorts but closer to the 31-40 age group, with largely a gender balance (Aparicio Gómez 2014). As to their level of education, Spanish emigration towards Europe up to the 1970s was mainly of low skilled workers. However, the outflows that continued after, in great part linked to Spain's entry into the UE, were more selective and composed by and large of highly educated individuals (Alaminos and Santacreu 2010; Alaminos et al. 2010). There are indications that the new emigration since the crisis started includes also mostly qualified people, but these tend to be based on non-representative studies (Aparicio Gómez 2014; González Enríquez and Martínez Romera 2014; Herrera 2014; Izquierdo et al. 2014; Navarrete Moreno 2013). Still, the combination of data from secondary and primary sources has created some public anxiety about the effects of emigration.

\subsection{Policy Responses to Recent Population Movements: The 'Forgotten Emigration'?}

Despite the fact that Spain has a long history of emigration dating back to at least the nineteenth century, is not until the 1950s during the Franco regime and the economic opening of the country that the phenomenon starts to be recognized and promoted as positive. Before, emigration was seen as a negative consequence of the 
failures of society and a personal tragedy (Fernández Asperilla 1998). This change coincides with the processes of industrialisation and urbanisation which created a large labour force that could not always be absorbed, hence the development of population movements inside the country and directed abroad. It was the perceived socioeconomic benefits of this migration abroad that led to a more active promotion and regulation of such flows. Benefits included a reduction in domestic unemployment, social savings as family reintegration was encouraged, and the remittances sent by emigrants.

Thus, from the beginning migration policy in Spain was conceived in utilitarian terms, linked mostly to the needs of the labour market; something that was reproduced when the country became a recipient of immigration. Another main element of migration policy in Spain is its reactiveness (Sánchez Alonso 2011): rather than being the result of reflexion on the long-term consequences, it reacts to what is happening at a precise moment. As a result, authors argue that in general migration flows in Spain have developed outside the legislation (i.e. initially in an 'irregular' manner). The first emigration policies emerged during the Franco period, under the aegis of the Spanish Institute of Emigration (Calvo Salgado et al. 2009), mainly to regulate flows, protect migrants and boost their links with the country in order to maximize benefits for the nation. In this task, authorized private institutions, such as the Catholic Church, played a significant role. The policies in large part consisted of bilateral agreements aimed at exporting labour and regulating workers' rights (Fernández Asperilla 1998).

It was these policies, albeit from a perspective of control and paternalistic assistance, that paved the way for the development later, especially with the restoration of democracy, of other measures such as education programmes, support for migrant associations, the creation of emigrant councils to promote institutional representation or actions directed at elderly migrants as well as the second and subsequent generations (Calvo Salgado et al. 2009). After the 1978 Constitution, emigrants became first class citizens with the same rights as other Spaniards, including the right to vote. At the regional level, the new autonomous communities in Spain also created their own plans to encourage and aid return migration. However, although emigration (and return to Spain) continued to be a political and public issue, as outflows declined some of its relevance was lost and no major legislative advancements were made for the next years. The lack of attention to emigration and emigrants persisted and became more blatant as the focus turned towards immigration flows. This led some experts to use the term "the forgotten emigration" when referring to the large population of Spaniards still residing abroad (Reques Velasco and de Cos Guerra 2003).

It is not until 2004-2008, under the Socialist Zapatero government, that new legislation is introduced. These laws responded partly to ideological interests and affected the descendants of previous migrants (Alemán and Alonso 2012). ${ }^{6}$ One

\footnotetext{
${ }^{6}$ Law 3/2005 offered economic benefits to Spanish citizens who left the country as a consequence of the Civil War (1936-1939), while Law 52/2007 (Law for Historical Memory) among other things allowed former Spanish nationals and their descendants abroad to recover their Spanish
} 
immediate consequence was the enlargement of the registered Spanish population abroad, as mentioned previously. However, the legislation also provided for the further regulation of the social, educational, cultural and participation rights of Spanish emigrants (Merino Hernando 2012). Mechanisms were designed to promote the creation of associations abroad and specific budget plans were dedicated to the descendants of Spanish emigrants, to reinforce their education, training and cultural links with Spain. This way the central government, with the support of regional administrations, after years of certain abandonment (except during electoral periods) tried to strengthen connections with Spaniards abroad as active citizens and potential voters.

The arrival of the crisis in 2008 and the inauguration of a conservative government in 2011 opened up a new period in migration policy. Initially, policies focused on the return of immigrants; following the utilitarian conceptions of the past, the idea was that if there was not enough work in Spain migrants should leave (thus reducing unemployment and social problems). Voluntary return plans had existed since 2003, both for humanitarian and other reasons. However, in 2008 the Socialist government implemented a new plan for jobless migrants to receive part of their accumulated unemployment benefit in their home countries, with the condition that they would not come back to Spain in at least 3 years. Although there is little information on the success of such plans, studies suggest that it has been rather modest, with return remaining a minority decision and in most cases undertaken outside institutionalized channels (Parella and Petroff 2014). Still, such outflows have served to cast recent emigration as a matter of mostly return migration, thus minimizing the phenomenon of the 'expulsion' of native Spaniards (or that of naturalized migrants, as well as second generation migrants born in the country) by the crisis and its potential consequences.

At the same time, the spending cuts and policies put in place by the ruling Partido Popular (PP conservative party) to respond to the crisis and reduce immigration (especially that of an 'irregular' nature) have affected Spaniards abroad, for instance through the closing down of consulates (Romero Valiente and Hidalgo-Capitán 2014). Another example are the new regulations introduced in 2012 to stop migrants in an irregular situation from receiving free healthcare that also limit access to health services in Spain to nationals residing outside the country. ${ }^{7}$ Equally, the electoral reforms of 2011 introduced the need for Spaniards abroad to actively express their desire to vote in order to be able to participate in national and regional elections in the home country (before, ballots were sent to them automatically). The result has been a massive reduction in participation (to $5 \%$ in the 2011 general elec-

nationality. Law 40/2006 (Statute for Spanish Citizens Abroad) was promulgated to boost the rights of emigrants.

${ }^{7}$ González Enríquez (2014a, b) explains that new regulations mean that Spaniards residing abroad for over 3 months lose their right to free healthcare in Spain; this could mean that less of them will register as permanent residents in the consulates. These new regulations were partly reversed in 2015, when the central government announced that it would reinstate the right to primary healthcare to all immigrants (El País 2015). 
tion, compared with $31 \%$ in 2008) (Ramírez 2015; Ruiz González 2014). These and other related issues have generated controversy in the wider political and public context as discussed next.

\subsection{The Wider Political and Public Debates: Ideological Differences and Biases}

Recent emigration from Spain started to become a political issue from 2011, following the change of government and publication of data indicating that the country was losing population (Nogueira 2011). Nevertheless, by and large the political debate has been low key and played along ideological lines. The right-wing government hardly refers to the phenomenon and when it does it describes outflows mainly as the result of return migration or of globalisation and mobility within Europe. Also, the authorities have made emphasis on the high skill levels of young Spaniards and their desire for adventure (ABC.es 2012). This discourse has been contested by the Socialist opposition (PSOE), who blames the PP for lack of opportunities in the country and alert about brain drain and loss of human capital (Quesada 2015). The left-wing parties also talk about "economic exile" and "economic migrants expulsed from Spain", with Podemos seeking to court the support of Spaniards abroad (Gómez 2014). The latest party that has emerged with force, the centre-right Ciudadanos, on the other hand, has not made many pronouncements on this topic. ${ }^{8}$

With regard to the attention paid by the main political groups to emigrants abroad, the traditional parties, PP and PSOE, have a network of supporters and institutions dedicated to them that tends to be activated at election time. ${ }^{9}$ Recently, both have made attempts at attracting the support of new emigrants. The PP, for instance, has promoted the idea of a "certificate" for emigrants returning to Spain to help with their social, health and labour reintegration. The PSOE, on the other hand, has asked for increased spending on social and other services for emigrants and the elimination of the new restrictions on voting from abroad, as well as proposing the creation of a plan for the return of high skilled emigrants. Newer parties such as Podemos include some proposals in its electoral programme, including the creation of a census of emigrants, social aid for those expulsed by the crisis and in need and mechanisms to make sure that those working in other EU countries do not lose their social security rights; while Ciudadanos hardly makes any references to Spaniards abroad in its website. ${ }^{10}$

\footnotetext{
${ }^{8}$ This party is more known for its hostile position on immigration than for its views on current emigration (El Mundo 2015).

${ }^{9}$ See information in the parties' websites: "PSOE en el Mundo" (PSOE in the World) http://web. psoe.es/ambito/mundo/news/index.do (Accessed 14 October 2015); PP "En el exterior"(PP abroad) http://www.pp.es/conocenos/en-el-exterior (Accessed 14 October 2015).

${ }^{10}$ Information obtained from parties' websites and newspapers. PP (http://www.pp.es/), PSOE (http://www.psoe.es/ambito/actualidad/home.do), Podemos (http://podemos.info/), Ciudadanos
} 
By contrast, the space that the new outflows have occupied in the wider public debates is more significant and varied. In the media, what is referred to as the "new" or "second" emigration has been quite visible. A brief overview of news on "emigration" published since 2011 by the two main newspapers in readership, El País (closer to PSOE) and El Mundo (more conservative), shows both have written numerous articles. The emphasis is on how the crisis is affecting highly educated young people as well as fostering return migration. El País has run a series covering the main destinations of recent outflows, people's reasons for leaving, difficulties encountered and family consequences. These stories talk about people been forced to emigrate because of the socioeconomic context and government policies (for example, cuts in research and university spending leading academics to emigrate). This raises questions about brain drain. El Mundo, on the other hand, also presents stories of successful business people and entrepreneurs that have emigrated. Both newspapers reported how in 2013 after 10 years Spain became a net receiver of migrant remittances again. In addition, there has been increasing concern about Spain's shrinking and ageing population, as immigration falls and emigration increases. The media has also echoed political and academic disputes about the nature of recent emigration, and flagged the issue of the external vote in the run-up to elections (Garea 2015).

Internet and the social media, on the other hand, have helped present more alternative or public views on the subject, and as a medium for emigrants to have their saying. For instance, an emotive video of two young emigrants returning home to see their families served to denounce the economic and political situation in Spain as a cause of emigration and became an instant success (González 2013). ${ }^{11}$ Several online platforms have also emerged to defend the views and rights of those who have left, such as Marea Granate (Maroon Tide), ${ }^{12}$ which describes itself as "a transnational movement formed by emigrants of the Spanish state and supporters, whose objective is to fight against the causes and those who have provoked the economic and social crisis that forces us to migrate" (see Chap. 7). Other similar alternatives include the campaign No nos vamos, nos echan (We don't leave, they throw us out), organized by the group Juventud Sin Futuro (Youth Without a Future), or Yo también soy una leyenda urbana (I am also an urban myth), launched by AACTE (Asociación para el Avance de la Ciencia y la Tecnología en España, Association for the Advancement of Science and Technology in Spain), created to protest against government comments saying that brain drain in Spain was an urban myth (Ansede 2014). ${ }^{13}$

\footnotetext{
(https://www.ciudadanos-cs.org/).

${ }^{11}$ The video is called LA SORPRESA: dedicado a todos los que están lejos, and was made by two young emigrants, Jorge and Esther. https://www.youtube.com/watch?v=qxu5W4bj4I8 (Accessed 15 February 2015).

${ }^{12}$ This refers to the colour of Spanish passports.

${ }^{13}$ Information obtained from their websites: http://mareagranate.org/, http://juventudsinfuturo.net/ and http://www.aacte.eu/wp/blog/2014/12/08/leyendas-urbanas/ (Accessed 15 February 2015).
} 
Finally, most of the public representations and discourses, including that of emigrants themselves, tend to offer an image of emigration as conformed only by young people and professionals. The emigration of the less skilled, poorer, older people and families remains almost invisible, referred to only as a thing of the past, somehow in contraposition to what is supposed to be happening now. Little is being said as well about issues such as the fact that many migrants abroad, despite their qualifications, are working below their skill levels and accessing the most precarious jobs, or about nationalized migrants re-emigrating (Domingo and Sabater 2013; Torres Pérez 2014). However, there is evidence that emigration in Spain is touching different sectors of society and is not as rosy a picture as some would like to paint.

\subsection{Conclusions}

The economic crisis has had a clear demographic impact in Spain. Following its emigration history, since the mid-1970s the country had enjoyed a positive migratory balance, with the number of people arriving increasingly superior to those leaving. These population movements were strongly linked to developments in the labour market, among other factors. Nevertheless, Spain is one of the European countries worst affected by the economic and financial crisis that erupted at the end of 2007. Although the impact on migration flows was not immediate, by 2010 the migratory balance had turned negative once again, as a result of both reduced immigration and increased emigration. Outflows have not reached the dimensions of the past, although official figures fail to reflect their real size. We know little about their characteristics as well, apart from the fact that they seem directed mainly towards Europe (in the case of native Spaniards) and the Americas (mostly return migration), and are partly composed of young, high skilled migrants. This generates concerns about the lack of work and opportunities in Spain, brain drain and human capital losses, and population ageing.

Despite such preoccupations, the political and policy responses have been quite subdued. Hardly any measures have been taken to know more about recent outflows or help new emigrants. Emigration policies have been almost absent from the Spanish panorama for decades, while measures implemented recently on healthcare or voting have actually proven detrimental to nationals abroad. Although the wider public debate has been more prolific, by and large it has followed ideological lines (for or against the government), as well as giving voice to some emigrants. In general, less skilled, poorer emigrants, as well as those returning or re-emigrating, remain absent from public debates. Partly, this is because the government presents recent emigration as mostly the result of labour globalisation and young people widening their experiences, while its emphasis is on demonstrating that the crisis is over. An example of this is a recent document of the think tank Real Instituto Elcano analysing Spain's strategic priorities on international migration, where out of six main points only one refers to emigration. This point describes recent outflows as "an opportunity to extend the presence of our country abroad, to create business and 
commercial networks and to spread the Spanish culture", and calls for the need to facilitate further external mobility (González Enríquez 2014b: 7). No reference is made to the causes of recent emigration or the social and personal consequences, especially for the most vulnerable emigrants. Clearly, more in-depth research and analysis of recent emigration flows from Spain is needed in order to detect the consequences and implement the right policies.

\section{References}

ABC.es. (2012, December 1). Marina del Corral achaca la emigración de jóvenes españoles "al impulso aventurero". ABC.ES. http://www.abc.es/economia/20121201/abci-emigracionjovenes-aventureros-marina-201212011242.html. Accessed 14 Feb 2015.

Alaminos, A., \& Santacreu, O. (2010). La emigración cualificada española en Francia y Alemania. Papers, 95(1), 201-211.

Alaminos, A., Albert, M. C., \& Santacreu, O. (2010). La movilidad social de los emigrantes españoles en Europa. Revista Española de Investigaciones Sociológicas, 129, 13-35.

Alemán Bracho, C., \& Alonso Seco, J. M. (2012). Políticas públicas para inmigrantes y emigrantes en España. Aproximación histórica, teórica y legislativa. Azarbe, Revista Internacional de Trabajo Social y Bienestar, 1, 7-19.

Alonso Pérez, M., \& Furio Blasco, E. (2010). La economía española. Del crecimiento a la crisis pasando por la burbuja inmobiliaria. Cahiers de civilisation espagnole contemporaine. De 1808 au temps présent, 6. Electronic ISSN 1957-7761.

Ansede, M. (2014, December 16). Los científicos exiliados claman que no son "una leyenda urbana”. El País. http://elpais.com/elpais/2014/12/16/ciencia/1418757917_801968.html. Accessed 15 Feb 2015.

Aparicio Gómez, R. (2014). Aproximación a la situación de los españoles emigrados: realidad, proyecto, dificultades y retos. Madrid: OIM.

Arango, J. (2013). Exceptional in Europe? Spain's experience with immigration and integration. Washington, DC: Migration Policy Institute.

Calvo Salgado, L. M., Fernádez Vicente, M. J., Kreienbrink, A., Sanz Díaz, C., \& Sanz Lafuente, G. (2009). Historia del Instituto Español de Emigración. Madrid: Ministerio de Trabajo e Inmigración.

DEMO \& Centre pour l'égalité des chances et la lutte contre le racisme. (2013). Migrations et populations issues de l'immigration en Belgique. Rapport statistique et démographique 2013. Louvain-la-Neuve: Centre de recherche en démographie et sociétés (DEMO), Université Catholique de Louvain. Brussels: Centre pour l'égalité des chances et la lutte contre le racisme.

Domingo, A., \& Sabater, A. (2013). Emigración marroquí desde España en contexto de crisis. Riem (Revista Internacional de Estudios Migratorios), 31(1), 29-60.

El Mundo. (2015, April 7). Ciudadanos apoya conceder la tarjeta sanitaria sólo a españoles y a inmigrantes con papeles. http://www.elmundo.es/espana/2015/04/07/5523a3b9e2704e4e558b 457a.html. Accessed 14 Oct 2015.

El País. (2015, March 3). Alonso anuncia que devolverá la atención primaria a los sin papeles. http://politica.elpais.com/politica/2015/03/31/actualidad/1427788718_943883.html. Accessed 13 Oct 2015.

Fernández Asperilla, A. (1998). La emigración como exportación de mano de obra: el fenómeno migratorio a Europa durante el franquismo. Historia Social, 30, 63-81. 
Garea, F. (2015, October 13). El PP se niega a eliminar las trabas al voto en el exterior. El País. http://politica.elpais.com/politica/2015/10/12/actualidad/1444668947_019129.html. Accessed 14 Oct 2015.

Gómez, L. (2014, September 15). Podemos lleva a Londres su mensaje a los 'emigrantes económicos expulsados de España'. El Mundo. http://www.elmundo.es/espana/2014/09/13/5414664de 2704e1f398b4580.html. Accessed 14 Feb 2015.

González, L. (2013, October 8). La Sorpresa: vídeo emotivo sobre emigrados que vuelven a su casa por sorpresa. El Huffington Post. http://www.huffingtonpost.es/2013/10/08/la-sorpresavideo-abrazos_n_4061923.html. Accessed 15 Feb 2015.

González Enríquez, C. (2013). ¿Emigran los españoles?. ARI, 39/2013. Madrid: Real Instituto Elcano.

González Enríquez, C. (2014a, May 6). Cuántos vienes y cuántos se van: El acceso a la sanidad y la oscuridad estadística sobre migraciones. Comentario Elcano, 42/2014. Madrid: Real Instituto Elcano.

González Enríquez, C. (2014b, July 17). Prioridades estratégicas de la acción exterior española en relación con las migraciones. Madrid: Real Instituto Elcano.

González Enríquez, C., \& Martínez Romera, J. P. (2014). Country focus: Migration of Spanish nationals during the crisis. Madrid: Real Instituto Elcano.

González-Ferrer, A. (2013a). La nueva emigración española. Lo que sabemos y lo que no. Zoom Político, 2013/18. Madrid: Laboratorio de Alternativas.

González-Ferrer, A. (2013b). Retorno y reintegración de los migrantes latinoamericanos en Europa. In FIIAPP (Ed.), Propuestas para vincular las políticas de migración y empleo (pp. 53-89). Madrid: FIIAPP.

Herrera, M. J. (2014). Migración cualificada de profesionales de España en el extranjero. In J. Arango, D. Moya Malapeira, \& J. Oliver Alonso (Eds.), Inmigración y emigración: mitos y realidades. Anuario de la Inmigración en España 2013 (pp. 91-107). Barcelona: CIDOB.

INE (2014). Estadística de Migraciones. Metodología. Instituto Nacional de Estadística (INE). http://www.ine.es/metodologia/t20/t2030277.pdf. Accessed 01 Mar 2016.

Izquierdo, A., \& Chao, L. (2014). Ciudadanos españoles producto de la Ley de la Memoria Histórica: motivos y movilidades. In P. Mateos (Ed.), Ciudadanía Múltiple y Migración: Una Perspectiva Latinoamericana (pp. 141-178). México DF: CIDE - CIESAS.

Izquierdo, M., Jimeno, J. F., \& Lacuesta, A. (2014). La emigración de españoles durante la Gran Recesión (2008-2013). Cuadernos Económicos de ICE, 87, 223-240.

Llano Ortíz, J. C. (2015). El estado de la pobreza $4^{\circ}$ Informe. Resumen ejecutivo. Seguimiento del indicador del riesgo de pobreza y exclusión social en España 2009-2013. EAPN-España. http:// www.eapn.es/ARCHIVO/documentos/noticias/1423562383_20150121_el_estado_de_la_ pobreza._seguimiento_del_arope_2013_resumenejecutivo.pdf. Accessed 10 Feb 2015.

Merino Hernando, M. A. (2012). Del "retorno del emigrante" a "la bienvenida del ciudadano en el exterior": los giros de la política española en el nuevo contexto migratorio entre España y Argentina. Stvdia Zamorensia, 11, 45-64.

National Statistics. (2015, February 26). National Insurance Number Allocations to Adult Overseas Nationals Entering the UK - registrations to December 2014. Statistical Bulletin. https://www. gov.uk/government/uploads/system/uploads/attachment_data/file/407501/NINo_Analytical_ Report_Feb15.pdf. Accessed 9 Oct 2015.

Navarrete Moreno, L. (coord.) (2013). La emigración de los jóvenes españoles en el contexto de la crisis. Análisis y datos de un fenómeno difícil de cuantificar. Madrid: Observatorio de la Juventud en España.

Nogueira (2011, July 25). España pierde población. El País. http://elpais.com/diario/2011/07/25/ sociedad/1311544803_850215.html. Accessed 14 Oct 2015.

Oliver Alonso, J. (2013). La inmigración y la doble recesión del mercado de trabajo en España 2011-12. In E. Aja, J. Arango, \& J. Oliver Alonso (Eds.), Inmigración y crisis: entre la continuidad y el cambio. Anuario de Inmigración en España (edición 2012) (pp. 28-58). Barcelona: CIDOB. 
OPAM. (2012). El impacto de la crisis económica en la situación laboral de los jóvenes inmigrantes. Tema OPAM, 7 (diciembre). Sevilla: Observatorio Permanente Andaluz de las Migraciones.

OPAM. (2013). España, ¿país de emigración? La imagen de éxodo a prueba de evidencia estadística. Tema OPAM, 8 (junio). Sevilla: Observatorio Permanente Andaluz de las Migraciones.

Ortega, E., \& Peñalosa, J. (2012). Claves de la crisis económica española y retos para crecer en la UEM. Documentos Ocasionales, 1201. Madrid: Banco de España.

Parella, S., \& Petroff, A. (2014). Migración de retorno en España: salidas de inmigrantes y programas de retorno en un contexto de crisis. In J. Arango, D. Moya Malapeira, \& J. Oliver Alonso (Eds.), Inmigración y emigración: mitos y realidades. Anuario de la Inmigración en España 2013 (pp. 62-87). Barcelona: CIDOB.

Quesada, J.D. (2015, August 30). Pedro Sánchez avanza un plan para recuperar el talento emigrado. El País. http://internacional.elpais.com/internacional/2015/08/29/actualidad/1440870356_439294.html. Accessed 14 Oct 2015.

Ramírez, P. (2015, February 3). Emigrantes españoles sin voto. El Mundo. http://www.elmundo.es/ espana/2015/02/03/54cfd8a8e2704ed42d8b4583.html. Accessed 13 Feb 2015.

Reques Velasco, P., \& de Cos Guerra, O. (2003). La emigración olvidada: la diáspora española en la actualidad. Papeles de Geografía, 37, 199-216.

Romero Valiente, J. M. (2003). Migraciones. In A. Arroyo Pérez (Ed.), Tendencias demográficas durante el siglo XX en España (pp. 207-253). Madrid: Instituto Nacional de Estadística.

Romero Valiente, J. M., \& Hidalgo-Capitán, A. L. (2014). El subregistro consular: magnitudes y efectos en las estadísticas de emigración españolas. OBETS. Revista de Ciencias Sociales, 9(2), 377-407.

Ruiz González, J. G. (2014). El voto exterior en España. Reflexiones tras la reforma. Más Poder Local, 19, 10-11.

Sánchez Alonso, B. (2011). La política migratoria en España.Un análisis de largo plazo. Revista Internacional de Sociología (RIS), 1, 243-268.

Torres Pérez, F. (2014). Crisis y estrategias de los inmigrantes en España: el acento latino. Revista CIDOB d'Afers internacionals, 106-107, 215-236.

Valero-Matas, J. A., Coca, J. R., \& Miranda-Castañeda, S. (2010). The migratory flows in Spain: An analysis of the migration and immigration input from European Union. Papeles de Población, 16(65), 233-256.

Open Access This chapter is licensed under the terms of the Creative Commons AttributionNonCommercial 2.5 License (http://creativecommons.org/licenses/by-nc/2.5/), which permits any noncommercial use, sharing, adaptation, distribution and reproduction in any medium or format, as long as you give appropriate credit to the original author(s) and the source, provide a link to the Creative Commons license and indicate if changes were made.

The images or other third party material in this chapter are included in the chapter's Creative Commons license, unless indicated otherwise in a credit line to the material. If material is not included in the chapter's Creative Commons license and your intended use is not permitted by statutory regulation or exceeds the permitted use, you will need to obtain permission directly from the copyright holder.

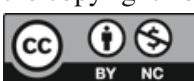




\title{
Chapter 7 \\ Restrictions on Access to Social Protection \\ by New Southern European Migrants \\ in Belgium
}

\author{
Jean-Michel Lafleur and Mikolaj Stanek
}

\subsection{Introduction}

Since the post-war period, immigration into Belgium has passed through several stages: an influx of guest workers (predominately from Southern Europe), the closure of migrant recruitment programmes and subsequent intensification of family reunification, asylum seeking, and increased numbers of arrivals of EU migrants. Although recent flows have seen a predominance of Central and Eastern European migrants, Southern European migration to Belgium has also gradually increased. Forty years after the end of the guest worker programmes, old migration routes to Belgium thus seem to be reopening.

The context in which Southern European migration is occurring today is, however, significantly different. Belgium is not the Member State that has received the largest numbers of EU migrants in recent years, and nor has it suffered the most from the economic crisis. Nevertheless, public support towards new EU migration has greatly decreased over the years (Freedman 2012). In particular, fears over the competition between native and foreign workers and concerns about the impact of the latter on the welfare system have become particularly salient.

Suspicion towards Southern European migration is a new phenomenon in Belgium. Indeed, following the guest worker era, the successful socio-economic and political integration of Southern European migrants had progressively turned them into the ideal-type of migrants in Belgian public debates. As we will show, this idealization process served mainly to delegitimize the presence of the third country

\footnotetext{
J.-M. Lafleur (西)

FRS-FRNS, Centre for Ethnic and Migration Studies (CEDEM), University of Liège,

Liège, Belgium

e-mail: jm.lafleur@ulg.ac.be

M. Stanek

Department of Sociology and Communication, University of Salamanca, Salamanca, Spain

e-mail: mstanek@usal.es
} 
migrants who arrived after them. Newcomers from Southern Europe, however, no longer benefit from the positive image associated with their predecessors. In policy terms, this change of attitude has materialized in new measures aiming at keeping undesirable EU migrants out. The most controversial of these measures consists of the removal of residence permits from unemployed EU citizens considered to represent an unreasonable burden on the Belgian public finances. Although migrants from Central and Eastern EU countries have been the most affected, a considerable number of nationals from North-Western and Southern EU countries have also been expelled.

The overall objective of this chapter is therefore to analyse how social policies have progressively become instruments of migration control in Belgium within the context of the economic crisis. First, we briefly discuss the recent economic and social situation, and explore the impacts of the economic downturn on the Belgian welfare system. We then describe past and recent migration flows to the country and discuss the main socio-demographic features of foreign residents from Southern Europe and other EU regions. We also highlight the socio-economic situation of Southern European migrants in terms of activity and unemployment rates, and of access to selected welfare benefits. In the second part of the chapter, we demonstrate how the process of idealization of Southern European immigration has taken place in Belgium. This process has resulted in an implicit classification between undesirable and desirable migrants. Accordingly, stricter immigration and integration policies are designed to keep the former out while still appearing attractive to the latter. We then focus on the specific policy of removing residence permits, targeting EU jobseekers during the economic crisis. We analyse the effects of this policy and, in the process, show that Belgium's strict welfare provisions not only limit the free mobility of workers in times of crisis but also stigmatize new EU migrants as "welfare shoppers". On examining the mobilization of different organizations, we conclude by showing that — while they are numerically fewer-new Southern European immigrants are in a better position than other new immigrants to challenge policies that affect their freedom of circulation.

\subsection{European Migration to Belgium: Present Meets Past}

\subsubsection{The Social and Economic Situation in Belgium in the Context of the Recent Global Crisis}

Similarly to the vast majority of EU Member States, Belgium was hit by the economic crisis in the late 2000s. In its initial phase (2008-2009), the turmoil mainly affected the financial sector, as Belgian banks faced liquidity and solvency problems. However, the economic and social setback of the financial system was further aggravated by a political crisis following the 2007 federal election, which left the country without a government for several months (Rihoux et al. 2011). Two 
indicators illustrate Belgium's difficulties at the time. First, the general government deficit rose from $-1.3 \%$ of GDP in 2008 to $-6.0 \%$ of GDP in 2009. Second, public debt increased from $89.6 \%$ of GDP in 2008 to $96.2 \%$ in 2009. In this period, Belgium was considered to be at high risk of falling into a long lasting and profound economic crisis along with other Member States such as Portugal, Spain, Ireland, Greece and Italy.

Even though in the years that followed, Belgium began to gradually recover from the initially dramatic turmoil, its economic performance remained fragile and mostly unstable (OECD 2015). As shown in Table 7.1, the basic indicators of the Belgian economy have shown a fluctuating pattern, with recovery in 2010 and 2011 and, again, a slight decline in the following 2 years. Overall, Belgium seems to have performed just slightly better than the EU and the Eurozone average, as illustrated by the fact that the Purchasing Power Parity adjusted Gross Domestic Product per capita has remained $20 \%$ above the average EU level throughout the economic crisis.

The financial turmoil in 2008 and 2009 has had negative consequences on the labour market in Belgium. Between 2008 and 2009, there was a net loss of 20,000 jobs, or a net drop of $1.2 \%$ (see Table 7.2). During the following 4 years (2010-

Table 7.1 Evolution of GDP indicators in Belgium and the EU-27

\begin{tabular}{l|l|l|l}
\hline & $\begin{array}{l}\text { GDP per inhabitant as a \% of EU } \\
\text { average: Belgium }\end{array}$ & $\begin{array}{l}\text { GDP growth rate: } \\
\text { EU-27 }\end{array}$ & $\begin{array}{l}\text { GDP growth rate: } \\
\text { Belgium }\end{array}$ \\
\hline 2003 & $124 \%$ & 1.5 & 0.8 \\
\hline 2004 & $121 \%$ & 2.5 & 3.6 \\
\hline 2005 & $120 \%$ & 2.0 & 2.1 \\
\hline 2006 & $118 \%$ & 3.4 & 2.5 \\
\hline 2007 & $116 \%$ & 3.1 & 3.4 \\
\hline 2008 & $116 \%$ & 0.5 & 0.7 \\
\hline 2009 & $118 \%$ & -4.4 & -2.3 \\
\hline 2010 & $120 \%$ & 2.1 & 2.7 \\
\hline 2011 & $120 \%$ & 1.7 & 1.8 \\
\hline 2012 & $120 \%$ & -0.5 & 0.2 \\
\hline 2013 & $119 \%$ & 0.2 & 0.0 \\
\hline 2014 & $119 \%$ & 1.4 & 1.3 \\
\hline
\end{tabular}

Sources: EU Labour Force Survey 2005-2013

Table 7.2 Evolution of unemployment rates in Belgium and the EU-27 2005-2013

\begin{tabular}{l|l|l|l|l|l|l|l|l|l}
\hline Unemployment rate & 2006 & 2007 & 2008 & 2009 & 2010 & 2011 & 2012 & 2013 & 2014 \\
\hline Belgium - total & 8.3 & 7.5 & 7.0 & 7.9 & 8.3 & 7.2 & 7.6 & 8.4 & 8.5 \\
\hline Belgium - long term & 4.2 & 3.8 & 3.3 & 3.5 & 4.1 & 3.5 & 3.4 & 3.9 & 4.3 \\
\hline Belgium - men & 7.4 & 6.7 & 6.5 & 7.8 & 8.1 & 7.1. & 7.7 & 8.7 & 9.0 \\
\hline Belgium - women & 9.3 & 8.5 & 7.6 & 8.1 & 8.5 & 7.2 & 7.4 & 8.2 & 7.9 \\
\hline EU-27 & 8.2 & 7.2 & 7,0 & 8.9 & 9.6 & 9.6 & 10.4 & 10.8 & 10.2 \\
\hline
\end{tabular}

Sources: Eurostat (EU Labour Force Survey), Algemene Directie Statistiek EAK 


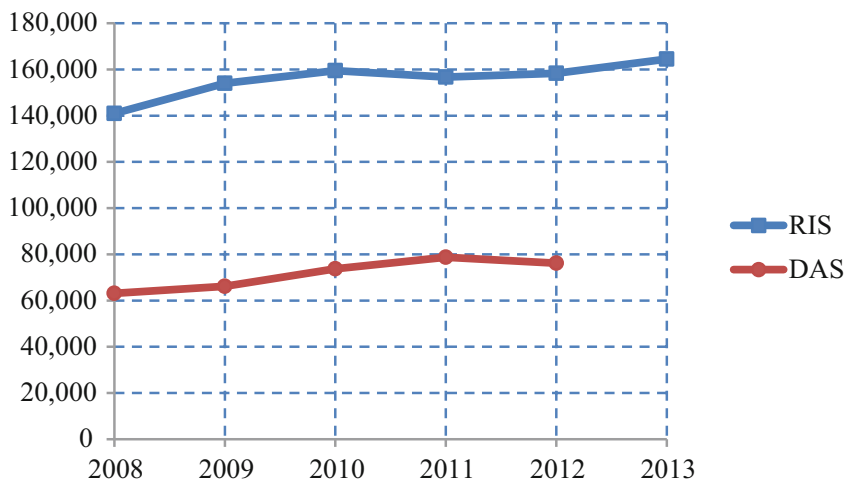

Fig. 7.1 Evolution of absolute numbers within the social integration income (RIS) and right to social aid (DAS) schemes (Source: Intégration Sociale 2013)

2014), variations in unemployment levels continued to reflect the volatile socioeconomic environment (De Mulder and Druant 2011). Yet, long-term unemployment remained relatively stable throughout this period, which confirms the conjectural nature of these fluctuations.

Belgium's approach to protecting employment during the crisis has consisted of keeping a fragile balance between activation policies undertaken on the federal and regional level, on the one hand, and austerity measures imposed by the European Commission on the other hand (Høj 2013). Activation measures have consisted mostly of implementing reduced working hours and temporary unemployment schemes to encourage employers not to terminate contracts (Hijzen and Venn 2011). Other measures have included the reduction of wage costs for certain categories of workers, full or partial exemption from social security contributions, and further training and job search assistance (Starke et al. 2011).

However, the economic slowdown and the instability of the labour market have resulted in the deterioration of living conditions and increasing inequalities in the country. This, in turn, has exerted a considerable stress on the non-contributory social assistance system. As shown in Fig. 7.1, between 2008 and 2013, the number of beneficiaries of the social integration income scheme (Revenu d'Intégration Sociale, hereafter $\mathrm{RIS}^{2}$ ) incremented by almost $14 \%$ per year (from approximately

\footnotetext{
${ }^{1}$ In addition to active employment policies implemented before and during the crisis, other contextual factors have mitigated the impact of the crisis. In this respect, we can mention the diversified nature of the Belgian economy and the relatively high proportion of public jobs (especially in Wallonia).

${ }^{2}$ The social integration income scheme (RIS) provides a non-contributory minimum income for people with no sufficient resources, who are unable to obtain them by their own efforts. Recipients are usually required to demonstrate the willingness to work, unless this is impossible for health or equity reasons. EU citizens who have a residence permit of more than 3 months in Belgium are eligible for RIS.
} 
141,000 to over 164,000). On the other hand, the number of individuals who qualified for the right to social aid sub-scheme (Droit à l'Aide Sociale, hereafter $\mathrm{DAS}^{3}$ ) incremented by almost $17 \%$, from approximately 63,000 in 2008 to 76,200 in 2013 (Intégration Sociale 2013).

The growing need for social assistance in times of crisis, however, has collided with the austerity measures imposed by both EU and Belgian federal policies. To meet the targets of the budget deficit reduction plans, employment activation and welfare policy expenditure have been accompanied by tax increases and cuts in public spending in areas such as health care, education and pension schemes (Castanheira et al. 2014; Pignal 2012). In addition, more stringent controls and the supervision of beneficiaries of social assistance have been introduced with the stated objective of reducing fraud and misuse of benefits (Nelson 2011). As we shall see in detail below, several of these restrictive measures have specifically targeted the immigrant population.

\subsubsection{Migration to Belgium: Historical Overview}

Belgium's migration history is profoundly shaped by its industrial history. During the nineteenth century and the progressive industrialization of the country, Belgium attracted a growing number of foreign workers, mostly from neighbouring countries. This phenomenon intensified after World War I, which, in addition to migration from those countries, saw significant numbers of migrants arriving from Southern Europe but also from Central and Eastern Europe, a situation that continued until the late 1930s (Stengers 1993). For instance, the number of Polish citizens recruited to work in Belgian coalmines grew from 198 in 1922 to almost 12,000 in 1930 (Caestecker 1990). After World War II, the economic recovery fostered renewed immigration into Belgium through bilateral recruitment agreements with sending countries. The first agreement was signed between Belgium and Italy in June 1946 and secured the recruitment of thousands of Italian workers for the coal and steel industries. As a consequence, Italians quickly became the largest foreign population in Belgium (see Table 7.3).

The growing demand for labour and a dispute with the Italian government over the working conditions of Italian workers in the 1950s prompted the Belgian authorities to look elsewhere for labour. New agreements were thus signed with Spain, Greece, Turkey and Morocco during this period. As shown in census data, the number of immigrants residing in Belgium almost doubled between 1947 and 1970 and accounted for over $7 \%$ of the total population in the eve of the Oil Crisis. Although Italians still constituted the largest foreign group (35\% of the total immigrant population) in 1970, other Southern Europeans communities-such as Spaniard and Greeks-had grown significantly. In the meantime, the Cold War reduced dramati-

\footnotetext{
${ }^{3}$ The right to social aid scheme (DAS) is aimed at covering the basic needs of those sectors of the population that do not qualify for the right to social integration benefits (e.g. asylum seekers or foreigners who have the right to reside in Belgium but are not yet registered in the population registry).
} 


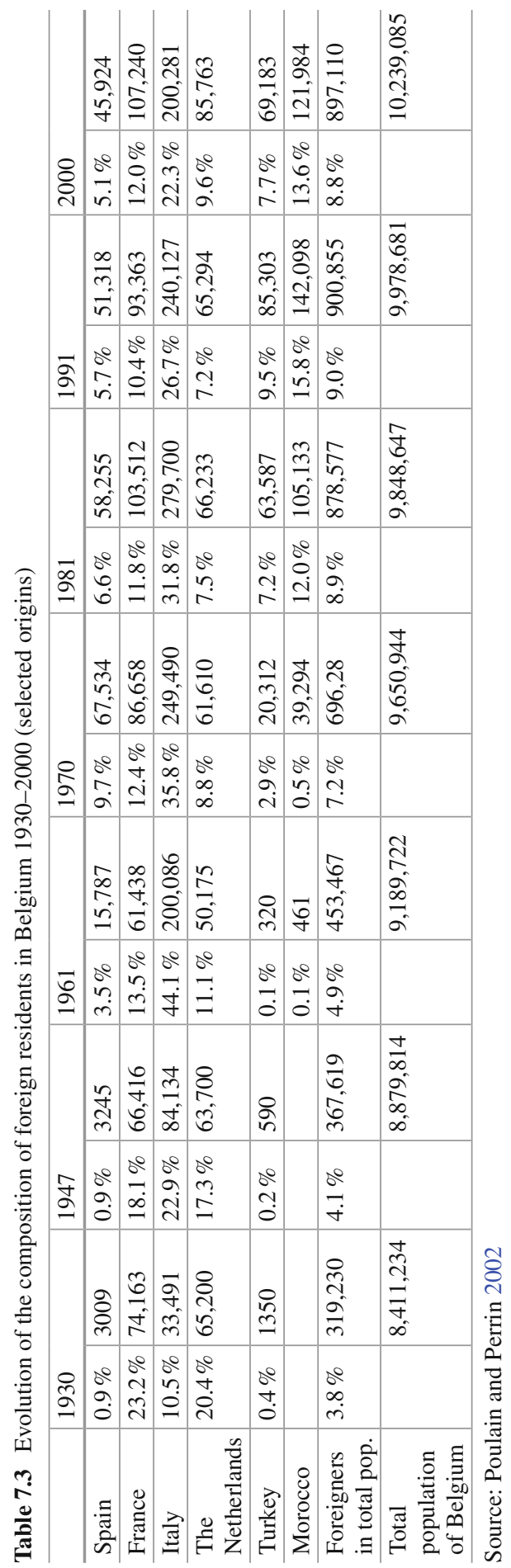


cally Central and Eastern European migration to Belgium. One last noteworthy feature of Belgium's post-war migration is that it explicitly allowed workers to come to the country with dependants in the hope that it would facilitate the workers' adaption to their new country while also addressing the country's demographic deficit (Bousetta et al. 2002).

This policy came to an end with the Oil Crisis and the government's decision in 1974 to cancel foreign worker recruitment programmes. However, this did not mean that migration stopped altogether. Indeed, the foreign resident population grew by almost 200,000 between 1970 and 1980 and their share of the total population reached $9 \%$. EU and third country migration to Belgium significantly transformed between the Oil Crisis and 2000. First, European migration to Belgium continued to intensify with the European integration process. In spite of the slowing down of the migration of Italian nationals, who had historically represented the largest European population in Belgium, growing immigration from neighbouring countries and from Central and Eastern Europe largely compensated for this. The consolidation of the role of Brussels as the capital of the EU, together with the growing needs for labour force_-in both high and low skilled occupations_-continued to attract EU citizens to Belgium. Overall, the percentage of EU migrants from neighbouring countries as part of the total foreign population increased, while that of Southern European migrants decreased. Second, family reunification schemes and relatively liberal asylum policies also increased the share of third country nationals in the total immigrant population during the same period.

\subsubsection{New Migration of Southern Europeans to Belgium: Flows and Stocks}

As discussed above, Belgium was not the EU Member State that was most affected by the financial and economic crisis. For this reason, it has remained a relatively attractive destination country since 2008. As shown in Table 7.4, the total yearly

Table 7.4 Migration flows in Belgium: inflows, outflows and net migration 2000-2012

\begin{tabular}{l|l|l|l}
\hline & Inflows & Outflows & Net migration \\
\hline 2005 & 97,888 & 44,298 & 53,590 \\
\hline 2006 & 101,872 & 45,573 & 56,299 \\
\hline 2007 & 109,926 & 45,437 & 64,489 \\
\hline 2008 & 126,069 & 52,407 & 73,662 \\
\hline 2009 & 126,877 & 57,873 & 69,004 \\
\hline 2010 & 140,375 & 55,468 & 84,907 \\
\hline 2011 & 138,071 & 58,000 & 80,071 \\
\hline 2012 & 125,000 & 70,357 & 55,000 \\
\hline
\end{tabular}

Source: RN-DGSIE 
inflow incremented from 93,345 to 138,071 between 2005 and 2011. Most of this increase was, however, due to recent EU enlargements to the East and the progressive removal by the Belgian authorities of the transition periods limiting the freedom of movement of citizens proceeding from those Member States. For instance, the absolute number of Polish migrants arriving in Belgium each year increased by almost 50\% from 6694 to 9851 between 2005 and 2011. Romanian migration also increased in a more dramatic fashion after the 2007 enlargement (from 3059 arrivals in 2006 to 11,784 in 2011).

Available data confirms that the deterioration of the economic situation in Southern EU countries has been a driving factor for the reactivation, after almost 40 years, of a new wave of migrants from this part of the continent. Although this flow is still comparatively less pronounced than migration from neighbouring countries and from Central and Eastern Europe, the number of new Southern Europeans arriving in Belgium is gradually increasing. As shown in Table 7.5, among Southern European countries, Spain is currently the nationality with the highest volume of inflow into Belgium. Arrivals of Spanish migrants nearly tripled from approximately 1900 in 2007 to over 5600 in 2011. In the case of Portuguese and Greeks migrants, the increase in arrivals has been significantly less intense when compared with the Spaniards and the Italians and, obviously, with nationals from new accession countries. In 2011, however, arrivals from Southern EU countries represented only $11 \%$ of the migration flows to Belgium.

The composition of the immigrant population by nationality has undergone considerable changes in recent years. Following the accession of Central and Eastern European countries, nationals from this area accounted for approximately $13 \%$ of the total population in 2013 (see Table 7.6). The stock of nationals from neighbouring countries, especially France and the Netherlands, has also increased steadily but its relative weight has remained unchanged $(30 \%)$. Similarly, despite the recent

Table 7.5 Immigration into Belgium by nationality 2005-2011

\begin{tabular}{l|l|l|l|l|l|l|l|l}
\hline & Nationality & 2005 & 2006 & 2007 & 2008 & 2009 & 2010 & 2011 \\
\hline 1 & France & 10,377 & 11,570 & 12,269 & 15,048 & 13,306 & 14,071 & 14,687 \\
\hline 2 & Romania & 2322 & 3059 & 5491 & 4222 & 3592 & 8447 & 11,784 \\
\hline 3 & $\begin{array}{l}\text { The } \\
\text { Netherlands }\end{array}$ & 10,109 & 11,488 & 11,370 & 12,321 & 9436 & 9654 & 10,198 \\
\hline 4 & Poland & 4815 & 6694 & 9393 & 9183 & 10,345 & 9121 & 9851 \\
\hline 5 & Morocco & 7106 & 7488 & 7831 & 8994 & 9957 & 10,360 & 9124 \\
\hline 6 & Spain & 1827 & 1848 & 1902 & 3095 & 3861 & 4795 & 5603 \\
\hline 7 & Italy & 2459 & 2613 & 2708 & 4499 & 4399 & 4747 & 5227 \\
\hline 8 & Bulgaria & 853 & 797 & 2625 & 7257 & 6568 & 4553 & 4740 \\
\hline 9 & Portugal & 1933 & 2030 & 2293 & 3541 & 3218 & 2910 & 3442 \\
\hline 10 & Turkey & 3389 & 2999 & 3180 & 3965 & 3852 & 3914 & 3265 \\
\hline$\ldots 17$ & Greece & 716 & 558 & 495 & 855 & 830 & 829 & 1201 \\
\hline & Others & 31,481 & 32,289 & 33,788 & 53,089 & 57,513 & 66,974 & 58,949 \\
\cline { 2 - 7 } & Total & 77,387 & 83,433 & 93,345 & 126,069 & 126,877 & 140,375 & 138,071 \\
\hline
\end{tabular}

Source: RN-DGSIE 


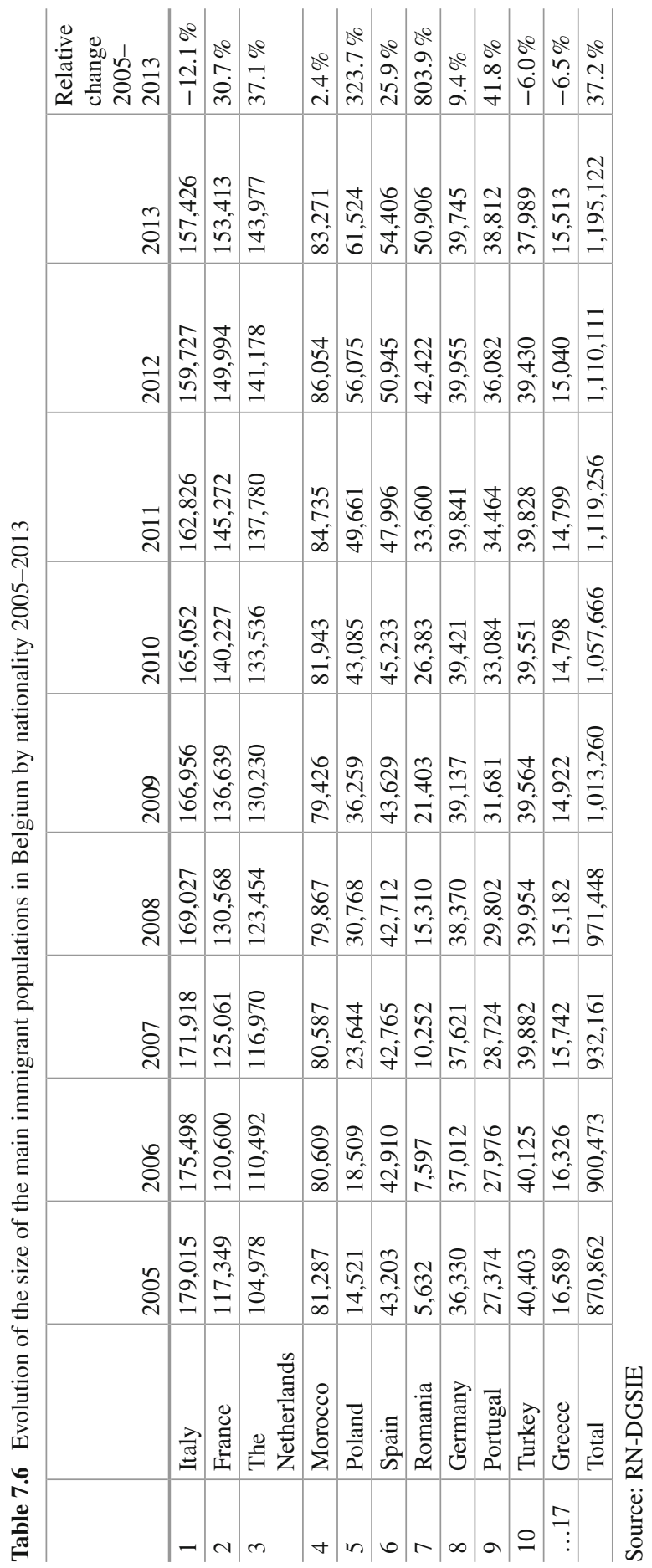


intensification of arrivals, the overall stock of nationals from Southern EU countries has not shown any growth. In 2005, the total number of Southern Europeans residing in Belgium was 266,181, while in 2014 it was 266,157. However, given the larger influx of migrants from Central and Eastern EU countries, the share of Southern Europeans in the total population diminished from $30 \%$ to $22 \%$. Italians and, to a much lesser extent, Greeks are two groups that decreased - respectively by 22,000 and 1000 individuals. This decline is directly related to the ageing of migrants that arrived in Belgium during the 1950s and 1960s economic boom, and this decline has not been halted by the arrival of new cohorts of migrants from Italy and Greece. By contrast, in the period under consideration, the Spanish and Portuguese populations increased by over 10,000 each. In these two cases, a longterm decrease has been reversed by the intensification of new arrivals since 2009 .

\subsubsection{Demographic and Socio-economic Characteristics of Southern European Migrants in Belgium}

As has been already stated, the demographic structure of the Southern European migration into Belgium is strongly conditioned by the past immigration of guest workers. Figure $7.2 \mathrm{a}-\mathrm{c}$ show the ageing demographic structure with a significant predominance of people over 45 years old. This corresponds to the cohorts of postwar guest workers. On the other hand, it can be observed that the age structure has been changing in recent years. The share of the oldest and the youngest age categories of Southern Europeans is gradually increasing. In the latter case, this is a result of the increasing inflow of new migrants after the outbreak of the crisis.

This duality in the age structure of the Southern European population contrasts with that of other large populations in Belgium. Nationals from the new accession members are concentrated in the categories of young adults and adults (24-44 years), which is consistent with the fact that this flow started relatively recently and is economically motivated. Migrants from neighbouring countries (France, Germany, Luxembourg and the Netherlands) show a relatively balanced age structure. This is due partly to the diversity of reasons motivating those migrants to move to Belgium (work, retirement, family migration, study and a change of tax domicile) and partly to the fact that flows from these countries have been consistent over time.

\subsubsection{Labour Market Situation and Access to Non-contributory Social Benefits}

The demographic structure of the Southern Europeans population is related to their socio-economic situation. According to Belgian Social Security statistics, in 2012, Southern Europeans had one of the lowest activity rates among all foreign-born 


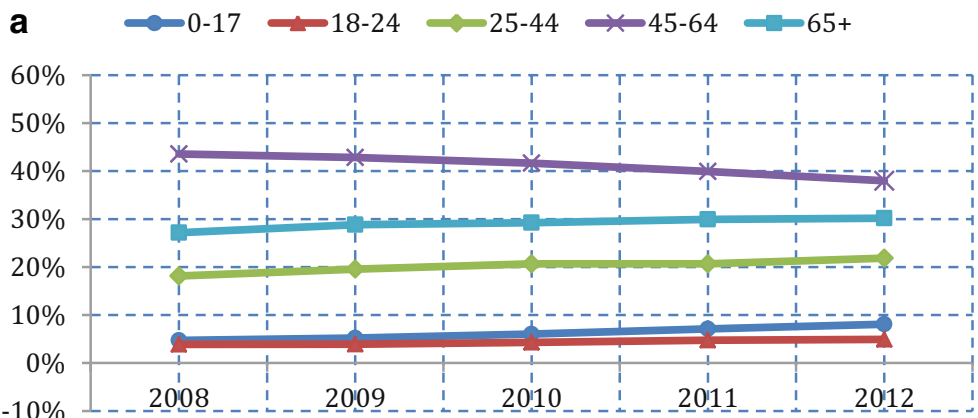

b

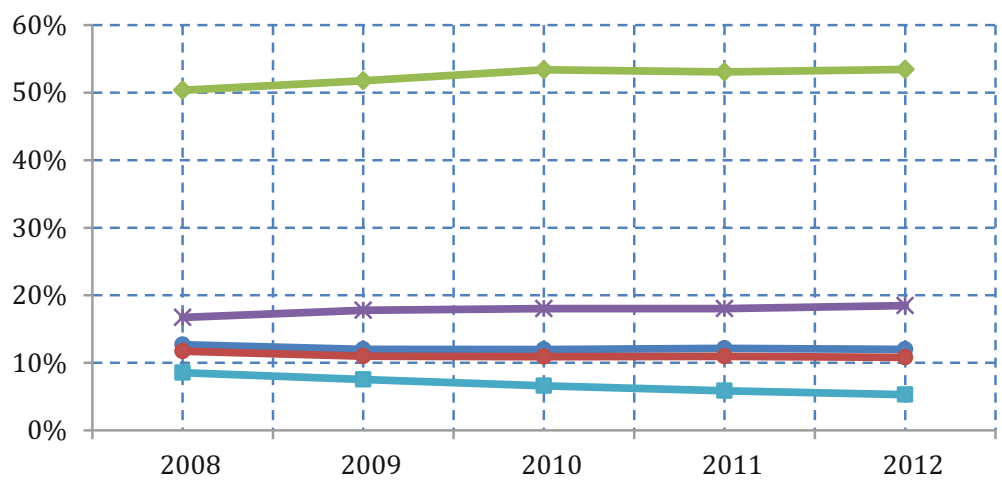

C

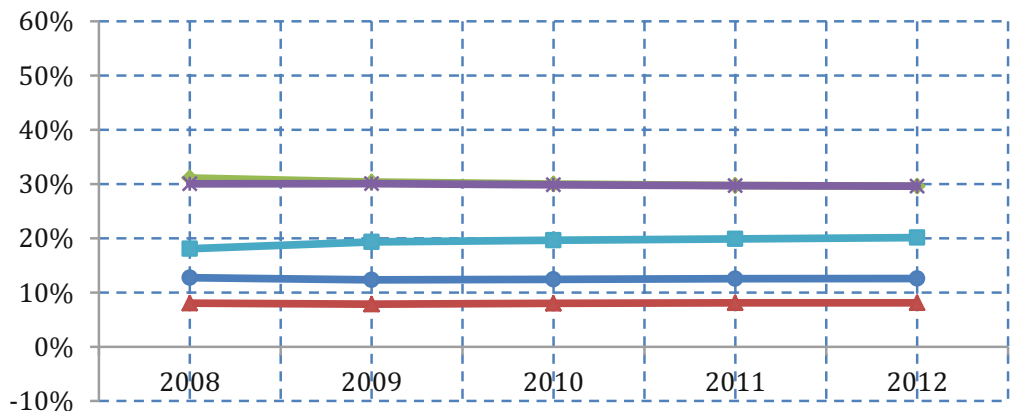

Fig. 7.2 Evolution of age composition from 2008 to 2012: (a) Southern Europeans*, (b) EU-12, (c) Neighbouring countries*** Greece, Italy, Portugal, Spain, **Bulgaria, Cyprus, Czech Republic, Estonia, Hungary, Lithuania, Latvia, Malta, Poland, Romania, Slovakia, Slovenia, ***France, Germany, Luxembourg, The Netherlands (Source: Banque Carrefour de la Sécurité Sociale 2008-2012) 
residents. This can be explained in good part by the age structure of this population. Indeed, if we focus specifically on the most economically active age categories (between 25 and 64), immigrants born in Southern EU countries are, along with migrants from the new accession countries, the most economically active population (see Table 7.7).

Yet, compared to migrants from other EU countries, Southern Europeans are also at higher risk of being unemployed. This phenomenon can be explained, on the one hand, by the obstacles faced by newcomers in the initial process of adjusting their skills to Belgian labour market needs. On the other hand, it is also possible that the new wave of Southern European migrants lacks the support structures and social networks that helped the incorporation of their predecessors into the labour market because of the considerable time gap between the old and the new migration waves (see discussion on this below).

Interestingly, the obstacles in the process of the labour market integration of new Southern European migrants have had no significant effect on their use of the Belgian non-contributory welfare system. As can be observed in Tables 7.8 and 7.9, Southern Europeans rely only to a modest degree on benefits provided by the social integration income (RIS) scheme, which is the main form of non-contributory social assistance in Belgium (see footnote 2). After initial increases in 2008 and 2009, the

Table 7.7 Activity and unemployment rates of foreign born populations by origin 2012

\begin{tabular}{l|l|l|l}
\hline & $\begin{array}{l}\text { Activity rate all } \\
\text { populations }\end{array}$ & $\begin{array}{l}\text { Activity rate age } \\
\text { group 25-64 }\end{array}$ & $\begin{array}{l}\text { Unemployment rate age } \\
\text { group 25-64 }\end{array}$ \\
\hline Southern EU & $33.5 \%$ & $63.5 \%$ & $12.9 \%$ \\
\hline EU-12 & $50.0 \%$ & $64.7 \%$ & $5.9 \%$ \\
\hline EU neighbour & $34.6 \%$ & $58.6 \%$ & $11.4 \%$ \\
\hline Other EU & $32.2 \%$ & $48.7 \%$ & $6.8 \%$ \\
\hline $\begin{array}{l}\text { Third country } \\
\text { nationals }\end{array}$ & $43.1 \%$ & $58.3 \%$ & $20.1 \%$ \\
\hline Belgium & $43.7 \%$ & $87.7 \%$ & $7.6 \%$ \\
\hline Total & $43.0 \%$ & $81.6 \%$ & $8.9 \%$ \\
\hline
\end{tabular}

Source: Banque Carrefour de la Sécurité Sociale

Table 7.8 Proportion of beneficiaries of the social integration income (RIS) scheme within each nationality

\begin{tabular}{l|l|l|l|l|l|l}
\hline & 2008 & 2009 & 2010 & 2011 & 2012 & 2013 \\
\hline Southern EU & $1.4 \%$ & $1.6 \%$ & $1.8 \%$ & $1.8 \%$ & $1.8 \%$ & $1.8 \%$ \\
\hline EU-12 & $3.1 \%$ & $3.9 \%$ & $4.6 \%$ & $4.2 \%$ & $3.5 \%$ & $3.0 \%$ \\
\hline EU neighbour & $1.6 \%$ & $1.7 \%$ & $1.8 \%$ & $1.7 \%$ & $1.5 \%$ & $1.5 \%$ \\
\hline Other EU & $0.6 \%$ & $0.7 \%$ & $0.8 \%$ & $0.7 \%$ & $0.6 \%$ & $0.6 \%$ \\
\hline Non-EU & $8.9 \%$ & $8.7 \%$ & $8.4 \%$ & $7.5 \%$ & $8.4 \%$ & $7.1 \%$ \\
\hline Belgium & $1.1 \%$ & $1.2 \%$ & $1.2 \%$ & $1.2 \%$ & $1.2 \%$ & $1.2 \%$ \\
\hline Total & $1.4 \%$ & $1.4 \%$ & $1.5 \%$ & $1.4 \%$ & $1.5 \%$ & $1.5 \%$ \\
\hline
\end{tabular}

Source: Intégration Sociale (2013) 
Table 7.9 Distribution of beneficiaries of the social integration income (RIS) scheme by nationality within the total population of Belgium

\begin{tabular}{l|l|l|l|l|l|l}
\hline & 2008 & 2009 & 2010 & 2011 & 2012 & 2013 \\
\hline Southern EU & $2.5 \%$ & $2.7 \%$ & $2.9 \%$ & $3.0 \%$ & $3.0 \%$ & $2.9 \%$ \\
\hline EU-12 & $1.4 \%$ & $2.0 \%$ & $2.8 \%$ & $3.1 \%$ & $3.0 \%$ & $2.9 \%$ \\
\hline EU neighbour & $3.3 \%$ & $3.5 \%$ & $3.5 \%$ & $3.4 \%$ & $3.2 \%$ & $3.1 \%$ \\
\hline Other EU & $0.2 \%$ & $0.2 \%$ & $0.2 \%$ & $0.2 \%$ & $0.2 \%$ & $0.1 \%$ \\
\hline Non-EU & $19.4 \%$ & $17.9 \%$ & $17.7 \%$ & $17.6 \%$ & $17.6 \%$ & $17.0 \%$ \\
\hline Belgium & $73.3 \%$ & $73.6 \%$ & $72.9 \%$ & $72.7 \%$ & $73.0 \%$ & $74.1 \%$ \\
\hline Total & $100.0 \%$ & $100.0 \%$ & $100.0 \%$ & $100.0 \%$ & $100.0 \%$ & $100.0 \%$ \\
\hline
\end{tabular}

Source: Intégration Sociale (2013)

share of beneficiaries of this scheme among Southern EU migrants has been constant and has not exceeded $2 \%$ of this population. It is, however, higher than the share of Belgians and migrants proceeding from neighbouring countries. On the other hand, the share of Southern Europeans who take up social benefits from the RIS scheme within the total population of Belgium has remained stable, at approximately $3 \%$. It remains to be seen, however, whether the limited use of noncontributory benefits by Southern EU migrants is related to the restrictions and controls implemented by the Belgian authorities against EU citizens in recent years (Mussche et al. 2013).

\subsection{Southern European Migrants in Belgium: From "Heroes" to "Welfare Shoppers"}

\subsubsection{EU Migrants in Belgium: Evolution of a Concept}

Large waves of immigration from Italy, and to a lesser extent from Spain, Portugal and Greece, durably marked Belgium's immigration history during the twentieth century. They have left visible traces until today in many neighbourhoods and many of these immigrants and their descendants now occupy visible positions in politics, trade unions, civil society organizations and academia. The most noticeable symbol of this process of socio-economic integration is the former Prime Minister Elio Di Rupo, the son of Italian immigrants who came to work in the Walloon coalmines in the 1940s. The visibility process led many observers to conclude that twentieth century Southern European immigration into Belgium had been a "success". In the past two decades, old Southern European migration flows to Belgium have thus been reinterpreted ex post as a desirable form of immigration in migration debates in Belgium. But how has this changed with the influx of new Southern European immigrants following the 2008 crisis?

As the origins of immigration into Belgium from Southern and Central and Eastern Europe predate the process of European integration, contemporary distinc- 
tions made between EU migrants and third country nationals have not always guided the country's immigration policies. As discussed in Part I, immigration into Belgium from border countries as well as from Italy and Poland finds its roots in the industrial development of Wallonia in the nineteenth century and it underwent its first acceleration after World War I. However, it was really after World War II that labour-intensive industries, such as coal and steel, stimulated demand for immigrant workers. The government thus developed a strategy of signing bilateral agreements first with Southern European countries and later with Morocco (1964), Turkey (1964), Tunisia (1969), Algeria (1970), and Yugoslavia (1970). At the time of the first bilateral agreement signed with Italy in 1946, the process of European integration had not yet started. The European Steel and Coal Community formed by Belgium, France, West Germany, Italy, the Netherlands and Luxembourg was, in fact, only founded in 1951. Similarly, when Belgium signed bilateral agreements with Spain (1956) and Greece (1957) in order to recruit workers, neither of these two countries was yet a member of the European Community. This means that early Southern European immigrants did not come to Belgium under Community provisions that would guarantee their freedom of circulation as workers. In other words, unlike today, the right of Southern European and North African immigrants to come to Belgium was guided by similar rules for most of the twentieth century.

This situation changed dramatically over time. The turning point came in 1968 with the end of visa requirements for EC migrants and the implementation of the right to look for employment without a work permit (Martiniello and Rea 2003). These differences in status between immigrants proceeding from EC countries (only Italians at the time) and other immigrants were further reinforced with the recession that started in the late 1960s. By then, the government had strictly reduced the issuance of new work permits, and on August 1, 1974, it officially put an end to 30 years of laissez-faire immigration policy by restricting entry only to immigrants whose skills were needed. In spite of this measure, the foreign population in Belgium continued to increase in the decades that followed through the granting of visas to skilled workers, the immigration of students, family reunification and the arrival of asylum seekers.

As the socio-economic conditions worsened in Belgium throughout the 1970s and 1980s, extreme-right parties began to build consistent electoral success on an anti-immigrant platform. By the early 1990s, the frontier between EC migrants and third country nationals was thus already very deep in Belgium. On the one hand, Italian and other Southern European migrants-as nationals of EC Member Statesenjoyed various employment, social and even political rights ensured by the treaties. On the other hand, immigrants and their descendants proceeding from other parts of the world did not enjoy the same level of protection and were most affected by rising unemployment and xenophobia.

In this declining socio-economic environment, which affected most particularly the industrial region of Wallonia, the legal differences between EC and non-EC migrants established by the treaties became progressively associated with normative judgements regarding these populations. More precisely, as xenophobia towards non-EC immigrants has risen, a process of idealization of old EU immigrants (and 
particularly of Italian immigrants) has taken place. In this sorting process between desirable and undesirable migrants, two dubious arguments are recurrently being used: the motivations behind migration and the "cultural distance" between migrants and natives.

Let us first address the argument regarding motivations behind migration. Since the 1980s, anti-immigration parties have supported the idea that - unlike their predecessors-new immigrants to Belgium do not come to work but to take advantage of the welfare system. One party in particular - the Flemish nationalist and xenophobic party Vlaams Blok (later renamed Vlaams Belang) — has played a key role in the dissemination of this idea. Following on from its initial major success in the 1987 legislative elections, running on an anti-immigration platform, the party formalized its stance through a 70-point programme in 1992. At the core of this programme, many measures proposed differentiated access to social security and unemployment benefits, as well as a different taxation system for EU and for nonEU migrants (Erk 2005). Rhetorical arguments regarding the cost that third country migrants supposedly represent to the Welfare State is historically based on immigration statistics describing the types of visa granted to third country nationals in order to gain access to the national territory. Recent data confirms that only a minority of third country nationals are granted residence permits for employment reasons $(7.6 \%$ in 2011), while family reasons (42.4\%), humanitarian reasons $(10.3 \%)$ and education $(6.7 \%)$ represent the bulk of registrations (UCL \& Centre pour l'égalité des chances 2013). This administrative data, however, exclusively reflects the modalities of access to the Belgian territory (e.g. family reunification, study, etc.) and not necessarily the intentions of migrants once they get there. In other words, the inability to obtain residence permits for employment reasons forces third country nationals to use other modalities to gain access to the employment market.

The second argument used to differentiate between new and old immigrants insists on the supposed inability of the new arrivals to integrate because their religious beliefs and cultural traits are too different from those of natives. Here too, the Vlaams Belang has repeatedly used this argument to target third country immigrants and their descendants (especially those proceeding from Maghreb and Turkey) (Meuleman and Billiet 2005). Depicting old Southern European immigrants as culturally closer to natives, however, contradicts historical accounts of the first decades of Italian presence in Belgium. As shown by Martiniello (1992) and Morelli (1988), Italian immigrants faced high levels of discrimination in Belgium after World War II and were, in fact, frequently accused of being too culturally different and too religious to integrate into Belgian society. Moreover, these scholars also showed that the high level of socio-economic integration of Italian migrants and their descendants must be related to other factors. The more favourable economic conditions in which these immigrants arrived and their ability to organize and occupy positions of power in trade unions and political parties are especially notable.

In spite of its lack of empirical foundations, this classification of immigrants into the categories of desirable post-war EU migrants and undesirable third country migrants has a strong performative value in Belgian politics. Over the years, classifying immigrants has been key to justifying selective migration and integration 
policies designed to continue to appeal to certain classes of foreigners. On the one hand, there are those that are considered to be both productive and able to integrate (e.g. highly-skilled workers, higher education students, wealthy EU citizens moving to Belgium for fiscal reasons, etc.), and public policies aim to attract these migrants into the country. On the other hand, there are the other groups that the policies aim to keep out (low-skilled immigrants, children and elderly citizens, asylum seekers, etc.). The reason for the spread of these ideas among Belgian policy-makers is to be found in the growing electoral success of the Vlaams Blok in Flanders. As shown by Koopmans et al. (2012), this party's success turned migration and integration into central political issues, so that other parties also felt compelled to pick up on these themes during their electoral campaigns (see also Coffé 2005; Adam and Torrekens forthcoming). It is certainly the case that Vlaams Blok's success never materialized in the form of government participation at the regional or federal level. Nevertheless, its ideas have been co-opted by other Flemish parties such as the right-wing nationalists of the New Flemish Alliance (N-VA) and the Liberal party (VLD), who have participated in several government coalitions since the late 1990s (Pauwels 2011).

With the accession of Central and Eastern European countries to the EU, the dichotomy between desirable and undesirable migrants has been applied for the first time within the category of EU migrants. In both 2004 and 2007, Belgium-along other Northern European Member States-implemented transitional measures to delay by 7 years the date at which workers from new EU Member States could enter freely into the Belgian job market. As of 1 January 2014, all restrictions have been lifted in relation to the mobility of EU-8 and EU-2 workers. Belgian political elites, however, continue to question the legitimacy of the arrival of these workers in Belgium. First, Central and Eastern European workers continue to be accused by the authorities of competing unfairly against Belgian workers. Second, the increased visibility of Central and Eastern European migrants in Belgian cities has led to increasing accusations of welfare shopping among new immigrants in Belgium. This latter consideration, in particular, has led the Government to develop new policies to control access to welfare in Belgium. A central policy that deserves further analysis in this respect is the removal of residence permits from EU citizens claiming benefits in Belgium. As we argue in the next section, this policy has led to increasing suspicion towards all EU migrants in Belgium and, in particular, towards new Southern European immigrants who left their country in the context of the economic crisis.

\subsubsection{Expelling EU citizens: The Limits of EU Citizenship in Belgium in Times of Crisis}

The belief among political elites that foreigners could be attracted to Belgium because of its welfare system is not new, but it has not always been considered to be a policy issue in the country. In fact, Belgium even advertised the advantages of its social system in Mediterranean countries after World War II, in order to persuade 
foreign workers to migrate to Belgium. It is thus only since the 1974 Oil Crisis and the subsequent decades of rising unemployment that foreigners have been increasingly depicted as a strain on the country's welfare system, in spite of a lack of evidence on the matter.

Over the years, the belief that welfare benefits are drivers of migration has guided several policy reforms that have affected both EU and third country nationals. In other words, restricting foreigners' access to social rights has progressively become a strategy to curb migration flows to Belgium. For instance, the idea that asylum seekers preferred Belgium over other destination countries because the benefits offered in Belgium were supposedly more generous than other countries led to the adoption of the 12 January 2007 Law on Asylum Seekers. This legislation strongly restricted the individual's ability to receive any cash-benefits during the asylum process.

Attempting to limit the immigration of EU citizens into Belgium through welfare provisions is, however, a much more complex matter, as the right to the mobility of workers and citizens has been enshrined in treaties and EU legislation over time. Nonetheless, looking at the number of EU citizens who have lost their right to reside in Belgium after claiming benefits in the country (Table 7.10), it can be argued that control on welfare use has effectively been turned into an instrument by which the Belgian authorities intend to keep undesirable EU migrants out.

As authorized by Directive 2004/38/EC on the right of citizens of the Union and their family members to move and reside freely within the territory of the Member States, Belgium started in 2011 to remove residence permits from EU citizens on the basis that they represent an "unreasonable burden on the social system" of the host country. Citizens targeted by this measure are not employees and the selfemployed but rather unemployed EU citizens. These EU citizens were originally granted residence permits in Belgium after they demonstrated that they possessed health coverage and sufficient resources to live autonomously. Nevertheless, because

Table 7.10 Number of residence permits removed by nationality on the basis of Directive 2004/38/EC

\begin{tabular}{l|l|l|l|l|l|l|l}
\hline & 2008 & 2009 & 2010 & 2011 & 2012 & 2013 & 2014 \\
\hline Spain & n/a & n/a & 75 & 98 & 207 & 323 & 245 \\
\hline Italy & n/a & n/a & 5 & 28 & 75 & 265 & 185 \\
\hline The Netherlands & n/a & n/a & 60 & 102 & 161 & 305 & 209 \\
\hline France & n/a & n/a & 21 & 32 & 109 & 176 & n/a \\
\hline Romania & n/a & n/a & 43 & 96 & 402 & 816 & 634 \\
\hline Slovakia & n/a & n/a & 91 & 108 & 73 & 60 & n/a \\
\hline Poland & n/a & n/a & 11 & n/a & 70 & 66 & n/a \\
\hline Bulgaria & n/a & n/a & 31 & 261 & 236 & 393 & 295 \\
\hline Other & n/a & n/a & 6 & 817 & 585 & 308 & 474 \\
\hline Total & 8 & 61 & 343 & 1542 & 1918 & 2712 & 2042 \\
\hline Change in $\%$ & - & $662,50 \%$ & $462,30 \%$ & $349,60 \%$ & $24,40 \%$ & $41,40 \%$ & $-24,70 \%$ \\
\hline
\end{tabular}

Sources: Office des Etrangers (2008, 2009, 2010, 2011, 2012, 2013) 
at some point after becoming official residents in Belgium, these immigrants received some form of social welfare, they began to be expelled. It is striking to note that the number of EU citizens expelled on this basis has increased exponentially between 2010 and 2013. Indeed, in 2011, the Minister for Social Integration De Block issued an executive order allowing an automatic exchange of information between the Social Security Administration and the Belgian Immigration Office. The consequence of this flow of information is visible in the sudden increase in the number of residence permits that were removed.

As documented in the press, many of these cases concerned citizens who applied for a living allowance or asked for social assistance because they faced a specific difficulty (e.g. unexpected hospital or utility bills). In other words, it is the category of EU citizens considered to be a burden that is being specifically targeted by this policy. Yet, the definition used by the administration to define social assistance is extremely lax. For instance, EU citizens hired under specific activation schemes financed by the Social Security Administration to work in schools or hospitals have equally faced expulsion. The rationale was that such publicly-financed jobs are not real jobs but rather a hidden form of assistance. The legality of such an interpretation has already been questioned in Belgium (Mormont and Neven 2014). Most importantly, however, the European Commission itself has expressed concerns over the sudden and dramatic increase in expulsions. It also reminded Belgium that it needed to pay more attention to the specific circumstances of each case, as expulsions should never be the automatic consequence of claiming benefits (European Commission 2014).

Looking at the nationality distribution of expelled EU citizens (Fig. 7.10), Romanians and Bulgarians have been the most affected by this policy. For these citizens, Belgium's policy to expel EU citizens who claim benefits is a continuation of previous policies that aimed to restrict their mobility into Belgium (e.g. through provisional measures that were only lifted on 1st January 2012). For this reason, the large-scale removal of residence permits among these nationals has failed to trigger a significant reaction from either Belgian civil society or the governments of these two countries of origin. The reaction has been very different towards the expulsion of nationals from old Member States, whose mobility into Belgium had never been a contentious issue (Dutch and French citizens) or whose mobility into Belgium had been idealized over the years (Italian, Spanish and Portuguese citizens).

Southern European migrants in particular have been most adamant in denouncing this new Belgian policy. During our fieldwork in Brussels, conducted between April 2013 and November 2015, we came across three examples that demonstrated this. First, the Brussels' chapter of the Spanish social movements $15 \mathrm{M}$ and Marea Granate (see Chap. 6) have organized numerous events in Brussels in order to shed light on the issue but also to raise awareness among new immigrants about the potential consequences of claiming social security benefits in Belgium. In November 2015, these movements also jointly submitted a petition to the European Parliament Committee on Petitions, asking Parliament to remind Belgium that the automatic nature of its expulsion policy does not respect Directive 2004/38/EC (Cuartopoder 10/11/15). Second, two other new associations created in Brussels by young Italian 
newcomers-Giovani Italiani Europa and La Comune del Belgio-have also organized numerous events to raise awareness about the difficulties of new Southern European immigrants. For instance, Giovani Italiani Europa organized two major conferences inside the European Parliament calling on European authorities to facilitate the mobility of young Europeans but also calling on the Italian government to adopt policies that will put an end to what they perceive as a new Italian brain drain. La Comune del Belgio, by contrast, adopted a more pragmatic approach by setting up jointly with a Belgian non-profit organization a free legal aid service. There, expelled EU citizens can receive advice on how to challenge the administrative decision that forces them to leave the country. Third, together with a series of Belgian non-profit organizations, the Italian Trade Union INCA-CGIL took the initiative to file a formal complaint to the European Commission regarding Belgium's widespread expulsion of EU citizens. The letter explicitly asked the Commission to initiate an infringement procedure against Belgium. Their hope is that this will force the country to abandon or revise a policy that these organizations consider to be a breach of Belgium's EU obligations (Osservatorio Inca 2014). The Commission responded favourably to this request and started to investigate the matter in June 2015.

Looking at these examples, it is striking to note that, despite being less affected numerically by the expulsions than other groups, Southern European immigrants have been the most vocal opponents of the policy. In fact, it is these immigrants who have managed to give the greatest visibility to the issue in the Belgian and European media and have managed to voice their concern in important forums such as the European Parliament. Similarly, Southern European migrants have set up the most elaborate legal responses to the policy using rights available at the Belgian and EU level. This situation can be explained by three factors. First, new Southern European immigration into the city of Brussels in particular consists partly of highly-educated migrants who come to Belgium in search of employment opportunities within the EU institutions and organizations that gravitate around them. It is thus not surprising that this particular kind of new migrant is more aware of his/her rights as a EU citizen but also more capable than others in catching the attention of the EU authorities and the international media in Brussels. Second, even though the members of these new Southern European organizations tend to underline the difficulty in connecting with co-nationals settled in Belgium for decades, new Italian immigrantsin particular - are able to benefit from an extensive network of Italian associations and institutions (trade unions, political parties, consulates, etc.), which have traditionally defended immigrant rights in Belgium. The support of the Brussels chapter of the Italian trade Union INCA-CGIL for the legal challenge against the Belgian government is very telling in this respect. Third, these new immigrant organizations are characterized by their strong transnational linkages with chapters of the same organizations in other destination countries or more simply with other immigrant organizations abroad. These linkages are an important resource when trying to challenge Belgium's policy at the supranational level: it gives them visibility in foreign media and contributes to exposing Belgium at the international level in the hope that it will change its policy. 


\subsection{Conclusions: Welfare Policies as Tools for Migration Control}

In this chapter, we have shown that Southern European Immigration into Belgium has increased since the beginning of the economic crisis. However, the arrival of these new immigrants failed to trigger perceptible fears among the population and policymakers. The perceived successful integration of previous immigration waves from Southern Europe has certainly facilitated the arrival of these new migrants in Belgium. At the same time, as a country characterized by a very open economy that also hosts several large international institutions, the number of high-skilled immigrants has also kept increasing at a steady rate over the last few years.

However, not all newcomers benefit from an equally positive perception in Belgium. The increasing presence of asylum seekers and EU citizens proceeding from Central and Eastern Europe has, by contrast, been received from a negative perspective, and specific policies have been designed in recent years to discourage these forms of migration. In particular, access to welfare has been increasingly described as a "pull factor" that attracts potential immigrants more interested in receiving benefits than in working. In this regard, the rhetoric of the former Secretary of State for Migration and Social Integration De Block has been crucial in depicting Belgium's social welfare as an overgenerous system that attracts undeserving immigrants. For this reason, she has made it a priority "to avoid immigrants coming here only to take advantage of the social system" (RTL info 2014).

However, this process of classification of immigrants as either desirable or undesirable largely precedes the crisis. Starting with the 1974 Oil Crisis and intensifying with the growing influence of the extreme-right party Vlaams Belang on Belgian politics, Belgium has made gaining access to its territory increasingly difficult for third country nationals, whilst still adhering fully to the principles of the freedom of circulation of workers and citizens within the European Union. This has led to a strong differentiation in legal status (and perception regarding the legitimacy of their presence) between EU and third country migrants, who had long been treated on an equal footing in Belgium until the middle of the twentieth century. The process of classification within the category of EU citizens is, however, a more recent phenomenon, whose implementation is rendered very difficult by the protection offered to mobile EU citizens by treaties and directives. The fear of a possible massive arrival of immigrants after the accession of Central and Eastern European countries to the EU in 2004 and 2007 pushed Belgium-along with other North-Western EU Member States - to restrict temporarily the freedom of circulation of those citizens described either as welfare shoppers or unfair competitors against Belgian workers. These restrictions have been progressively lifted, but the fear of invasion remains. Consequently, Belgium is now using other measures to keep undesirable EU citizens out, such as the intensification of controls on worksites where posted workers are traditionally employed.

With the economic crisis and the increasing pressure on public finance, this process of delegitimizing the presence of some EU citizens in Belgium has intensified. 
As Directive 2004/38/EC offers very little room for restricting the rights of mobile EU citizens, the control of EU citizens' use of welfare rights is increasingly being used as a means to restrict access to the territory only to working EU citizens who are not considered to compete unfairly with Belgian workers. Whereas this policy targets primarily Romanian and Bulgarian citizens, the presence of Spanish, Dutch, Italian and French citizens in the list of nationalities most affected by the removal of residence permits has triggered strong debates in Belgium. The visibility given to this strict policy by the Secretary of State to Migration De Block has only contributed to reinforce the cliché according to which immigrants move to Belgium to take advantage of its welfare system. In addition, it has extended this cliché to EU citizens whose presence in Belgium had never previously been questioned (the French and Dutch) or had even been considered as an example of successful integration within Belgium (Italians).

Previous occasions during which Roma migrants from Romania and Slovakia had been removed by the police from houses they illegally occupied had already confirmed that citizens from those Member States were considered undesirable in Belgium. To see French and Southern European citizens expelled on similar grounds as Romanians and Bulgarians, however, marked a key moment in Belgium's policy towards mobile EU citizens. By applying the strictest interpretation of Directive 2004/38/EC when it comes to "welfare abuse" by mobile EU citizens, Belgium clearly intends to set strict limits on the concept of EU citizenship through its social policy. Unlike other groups of new immigrants, Southern European migrants have mobilized more visibly and more formally against Belgium's policy. This greater ability to mobilize, we argue, is supported by the specific profile of the new Southern European immigrants, their transnational connections and their ability to connect with home and host country institutions and organizations that have defended immigrant rights for decades.

\section{References}

Bousetta, H., Jacobs, D., Kagné, B., Martiniello, M., Nys, M., Rea, A., et al. (2002). Multicultural policies and modes of citizenship in Belgium: The cases of Antwerp, Liège and Brussels. Brussels: IPSoM.

Caestecker, F. (1990). Le multiculturalisme de la Belgique: Une analyse de la politique de scolarisation des enfants polonais en Belgique 1923-1940. Belgisch Tijdschrift voor Nieuwste Geschiedenis, 21(3/4), 535-573.

Castanheira, M., Rihoux, B., \& Bandelow, N. C. (2014). 2014 Belgium report sustainable governance indicators 2014 project. Gütersloh: Bertelsmann Stiftung.

Coffé, H. (2005). The adaptation of the extreme right's discourse: The case of the Vlaams Blok. Ethical Perspectives: Journal of the European Ethics Network, 12(2), 205-230.

Cuarto Poder. (2015). Marea Granate y 15M Bruselas denuncian las expulsiones de españoles en la UE [Marron Wave and M15 report expulsions of Spaniard from the EU]. http://www.cuartopoder.es/invitados/2015/11/10/marea-granate-y-15m-bruselas-denuncian-las-expulsiones-deespanoles-en-la-ue/6333. Accessed 15 Nov 2015.

De Mulder, J., \& Druant, M. (2011). The Belgian labour market during and after the crisis. Economic Review, 1, 89-104. 
Erk, J. (2005). From Vlaams Blok to Vlaams Belang: The Belgian far-right renames itself. West European Politics, 28(3), 493-502.

European Commission. (2014). Libre circulation: La Commission demande à la Belgique de respecter les règles de l'UE (pp. 1-11). Brussels: European Commission.

Freedman, M. (2012). Changes in attitudes towards immigration: Evidence from the European debt crisis (European Forum at the Hebrew University, Jerusalem Working Paper, 115). Jerusalem: Hebrew University

Hijzen, A., \& Venn, D. (2011). The role of short-time work schemes during the 2008-09 recession (OECD Social, Employment and Migration Working Papers, Vol. No. 115). Paris: OECD Publishing.

Høj, J. (2013). Enhancing the inclusiveness of the labour market in Belgium (Economic Department Working Paper, 1009). Paris: OECD

Intégration Sociale. (2013). Bulletin statistique. Brussels: Intégration Sociale.

Koopmans, R., Michalowski, I., \& Waibel, S. (2012). Citizenship rights for immigrants: National political processes and cross-national convergence in Western Europe, 1980-2008. American Journal of Sociology, 117(4), 1202-1245.

La Libre Belgique. (2014, November 22). Theo Francken veut une immigration plus active. $L a$ libre Belgique, 4-5.

Martiniello, M. (1992). Leadership et pouvoir dans les communautés d'origine immigrée. Paris: L'Harmattan.

Martiniello, M., \& Rea, A. (2003). Belgium's immigration policy brings renewal and challenges (Country series). Washington, DC: Migration Policy Institute. http://www.migrationpolicy.org/ article/belgiums-immigration-policy-brings-renewal-and-challenges). Accessed 17 Nov 2015.

Meuleman, B., \& Billiet, J. (2005). Etnocentrisme in Vlaanderen: opmars of afname? De evolutie van de perceptie van etnische dreiging tussen 1991 en 2004 en de relatie met institutioneel vertrouwen (pp. 37-60). Brussels: Ministerie van de Vlaamse Gemeenschap.

Morelli, A. (1988). L'appel à la main d'oeuvre italienne pour les charbonnages et sa prise en charge à son arrivée en Belgique dans l'immédiat après-guerre. Revue Belge d'Histoire Contemporaine, XIX(1-2), 83-130.

Mormont, H., \& Neven, J.-F. (2014). Le droit à l'aide sociale et le droit à l'intégration sociale en faveur des étrangers: questions d'actualité. In J. Clesse \& J. Hubin (Eds.), Questions spéciales de droit social Hommage à Michel Dumont (pp. 13-110). Bruxelles: Larcier.

Mussche, N., Corluy, V., \& Marx, I. (2013). Migrant access to social security - policy and practice in Belgium. Study for the Belgian national contact point of the European Migration Network $(E M N)$. Brussles: European Commission/European Migration Network.

Nelson, K. (2011). Improving the efficiency of social protection. Peer review in social protection and social inclusion. Brussels: European Commission.

OECD. (2015). OECD economic surveys. Belgium February 2015. Paris: OECD Publishing.

Office des Etrangers. (2008). Rapports d'activités. Bruxelles: SPF Intérieur.

Office des Etrangers. (2009). Rapports d'activités. Bruxelles: SPF Intérieur.

Office des Etrangers. (2010). Rapports d'activités. Bruxelles: SPF Intérieur.

Office des Etrangers. (2011). Rapports d'activités. Bruxelles: SPF Intérieur.

Office des Etrangers. (2012). Rapports d'activités. Bruxelles: SPF Intérieur.

Office des Etrangers. (2013). Rapports d'activités. Bruxelles: SPF Intérieur.

Osservatorio Inca. (2014). Expulsions de citoyens européens de Belgique. Violation des articles 7 et 14 de la Directive 2004/38 sur le droit de séjour des citoyens UE et des articles 4 et 61 du Règlement $n^{\circ} 883 / 2004$ sur le coordination de la sécurité sociale. http://www.osservatorioinca. org/section/image/attach/Lettre_CE_2014_11_04.pdf. Accessed 16 Nov 2015.

Pauwels, T. (2011). Explaining the strange decline of the populist radical right Vlaams Belang in Belgium: The impact of permanent opposition. Acta Politica, 46(1), 60-82.

Pignal, S. (2012). Belgium aims to cut $€ 1$ bn from spending in 2012. Financial Times. http://www. ft.com/cms/s/0/a46fc5c6-3a10-11e1-a8dc-00144feabdc0.html\#axzz4D0b9jds9 
Poulain, M., \& Perrin, N. (2002). The demographic characteristics of immigrant populations in the Belgium. In The demographic characteristics of immigrant populations. Population studies, No. 38. Strasbourg: Council of Europe Publishing.

Rihoux, B., Dumont, P., De Winter, L., Deruette, S., \& Bol, D. (2011). Belgium. European Journal of Political Research, 50(7-8), 913-921. doi:10.1111/j.1475-6765.2011.02013.x.

RTL info. (2014). Maggie De Block: "Il faut éviter que des gens profitent de notre système social". http://www.rtl.be/info/belgique/politique/1053395/maggie-de-block-il-faut-eviter-que-des-gensprofitent-de-notre-systeme-social-video

Starke, P., Kaasch, A., \& van Hooren, F. (2011). Explaining the variety of social policy responses to economic crisis: How parties and welfare state structures interact (TranState Working Papers, Vol. 154). Hamburg: Leibniz Information Centre for Economics.

Stengers, J. (1993). De immigratie van 1830 tot 1914: cijfermateriaal. In A. Morelli (Ed.), Geschiedenis van het eigen volk. De vreemdeling in België van de prehistorie tot nu (pp. 103114). Leuven: Kritak.

UCL, \& Centre pour l'égalité des chances. (2013). Rapport statistique et démographique 2013. Migrations et populations issues de l'immigration en Belgique. Brussels: Centre pour l'égalité des chances.

Open Access This chapter is licensed under the terms of the Creative Commons AttributionNonCommercial 2.5 License (http://creativecommons.org/licenses/by-nc/2.5/), which permits any noncommercial use, sharing, adaptation, distribution and reproduction in any medium or format, as long as you give appropriate credit to the original author(s) and the source, provide a link to the Creative Commons license and indicate if changes were made.

The images or other third party material in this chapter are included in the chapter's Creative Commons license, unless indicated otherwise in a credit line to the material. If material is not included in the chapter's Creative Commons license and your intended use is not permitted by statutory regulation or exceeds the permitted use, you will need to obtain permission directly from the copyright holder.

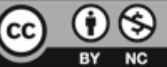




\title{
Chapter 8 \\ Southern Europeans in France: Invisible Migrants?
}

\author{
Tatiana Eremenko, Nora El Qadim, and Elsa Steichen
}

\subsection{Introduction}

France has a long immigration history and has been an important destination for migrants from Southern Europe throughout the twentieth century. Faced with labour shortages as early as the nineteenth century, France actively recruited workers from neighbouring countries until the start of the 1970s. Italians were among the first foreign nationals to be recruited, along with Belgians and Polish. They represented the largest immigrant community in France in the 1950s. The number of Spanish migrants, present in the south of France from the start of the twentieth century, grew in the mid-1940s, following the civil war. Portuguese migration took off later, at the end of the 1950s and rapidly became the largest migrant community by the mid1970s. However, by the time of the 1974 economic crisis migration flows from Southern Europe had declined and they have remained low in the last decades.

The current economic crisis does not appear to have changed this evolution and France has not emerged as an important destination for Southern European migrants as have Germany and the UK. Although France fared relatively well at the start of the current economic crisis, it has experienced low economic growth and high unemployment rates in recent years, thus explaining its overall low attractiveness for Southern Europeans and EU migrants looking for work. Although their numbers have increased and represent a growing proportion of recent flows to France (Brutel 2014), they remain low compared to numbers in Germany and the UK.

\author{
T. Eremenko $(\bowtie)$ \\ Institut National d'Études Démographiques (INED), Paris, France \\ e-mail: tatiana.eremenko@ined.fr \\ N. El Qadim \\ CRESPPA-LabTop, Université Paris 8, Paris, France \\ E. Steichen \\ Université Paris 1 Panthéon-Sorbonne, Paris, France
}


Despite this statistical reality, EU mobility and more generally the role of the EU in economic and social policy have been at the forefront of debates in France since the early 2000s. Although these debates are a continuation of historical debates regarding immigration in France, they have taken a new intensity in the context of the current economic crisis. These debates have targeted two populations - the Roma and posted workers - with both groups being portrayed as threats to the French welfare state. The number of posted workers has increased threefold between 2007 and 2013, reaching 212,641 workers posted in France during the last available year, and Southern Europeans constitute a growing proportion of this number. Although posted workers are, according to official EU definitions, not migrants and do not fall within the legal framework relative to intra-European mobility as such, their characteristics and experiences are similar to other groups of temporary migrant workers. This led us to consider their case as an example of crisis induced work mobility in the EU when considering the French case.

Section 8.2 of this chapter provides a brief overview of the socio-economic situation in France, before analysing the evolutions in the volume and characteristics of recent migrants and posted workers since the start of the 2000s. Section 8.3 analyses debates concerning intra-European mobility through the lens of two recent debates on the Roma and posted workers. In both cases, the issue of the national model of social protection is central. Although Southern European nationals have not been central to any of the debates - the image of posted workers focused on Eastern Europe - they are directly affected by their results and policy changes. Moreover, we argue that the focus of political debates on other populations in France has contributed to the relative invisibility of Southern European immigrants in this country.

\subsection{A Quantitative Assessment of Crisis-Induced Migration to France}

\subsubsection{Socio-economic Situation in France}

The current economic crisis did not impact France as hard as other European countries. In 2009, the GDP decreased by $3 \%$, but recovered in the following years, increasing by $2 \%$ in 2010 and 2011 (Larrieu et al. 2014). However in the most recent years, the socio-economic situation has stagnated with a growth rate under $1 \%$ from 2012 to 2014 (Debauche et al. 2015).

The evolution of the employment situation reflects that of the GDP. In 2009 the number of jobs decreased and the unemployment rate went from $7.1 \%$ the previous year to $8.7 \%$ (Table 8.1 ). The creation of government aided jobs and the increase in independent activity limited the contraction of the labour market. In 2012 and 2013 job losses resumed and the unemployment rate started increasing again, reaching $9.8 \%$ in 2013 . This evolution has led to 843,000 additional unemployed persons 
Table 8.1 Evolution of unemployment (ILO definition) by sex, age, occupation and level of education

\begin{tabular}{|c|c|c|c|c|c|c|c|c|c|c|}
\hline & 2004 & 2005 & 2006 & 2007 & 2008 & 2009 & 2010 & 2011 & 2012 & 2013 \\
\hline $\begin{array}{l}\text { Number of } \\
\text { unemployed } \\
\text { (thousands) }\end{array}$ & 2,299 & 2,320 & 2,320 & 2,121 & 1,970 & 2,457 & 2,504 & 2,474 & 2,672 & 2,813 \\
\hline Male & 1,123 & 1,133 & 1,142 & 1,062 & 987 & 1,281 & 1,287 & 1,255 & 1,405 & 1,486 \\
\hline Female & 1,177 & 1,187 & 1,178 & 1,059 & 984 & 1,176 & 1,217 & 1,219 & 1,267 & 1,327 \\
\hline $\begin{array}{l}\text { Unemployment } \\
\text { rate }(\%)\end{array}$ & 8.5 & 8.5 & 8.4 & 7.7 & 7.1 & 8.7 & 8.9 & 8.8 & 9.4 & 9.8 \\
\hline \multicolumn{11}{|l|}{ By sex } \\
\hline Male & 7.8 & 7.8 & 7.9 & 7.3 & 6.7 & 8.7 & 8.7 & 8.5 & 9.4 & 10.0 \\
\hline Female & 9.3 & 9.3 & 9.1 & 8.1 & 7.4 & 8.8 & 9.1 & 9.1 & 9.3 & 9.7 \\
\hline \multicolumn{11}{|l|}{ By age } \\
\hline 15-24 years & 19.8 & 20.3 & 21.3 & 18.8 & 18.3 & 22.9 & 22.5 & 21.8 & 23.6 & 23.9 \\
\hline $25-49$ years & 7.8 & 7.8 & 7.6 & 7.0 & 6.3 & 7.8 & 8.0 & 8.0 & 8.7 & 9.1 \\
\hline 50 years or more & 5.2 & 5.0 & 5.1 & 4.6 & 4.3 & 5.2 & 5.5 & 5.5 & 5.9 & 6.5 \\
\hline \multicolumn{11}{|l|}{ By educational level } \\
\hline Tertiary & 6.4 & 6.2 & 5.9 & 5.5 & 4.5 & 5.5 & 5.5 & 5.4 & 5.6 & na \\
\hline Secondary & 8.2 & 8.1 & 8.1 & 7.2 & 6.9 & 8.8 & 8.8 & 8.8 & 9.8 & na \\
\hline Less than secondary & 12.3 & 12.9 & 13.1 & 12.2 & 11.7 & 14.2 & 15.3 & 15.1 & 16.0 & na \\
\hline \multicolumn{11}{|l|}{ By occupation } \\
\hline Executives & 4.1 & 4.2 & 3.7 & 3.0 & 2.8 & 3.5 & 3.7 & 3.5 & 3.5 & 3.9 \\
\hline $\begin{array}{l}\text { Intermediate } \\
\text { occupations }\end{array}$ & 5.2 & 4.8 & 4.6 & 4.4 & 3.8 & 5.0 & 4.6 & 4.8 & 5.1 & 5.2 \\
\hline Employees & 8.6 & 9.0 & 8.8 & 7.8 & 7.0 & 8.3 & 8.9 & 9.2 & 9.7 & 10.0 \\
\hline Workers & 10.5 & 10.8 & 11 & 10.1 & 9.8 & 12.6 & 12.8 & 12.3 & 13.8 & 14.6 \\
\hline Skilled workers & 7.4 & 7.7 & 7.6 & 7.2 & 7.0 & 8.9 & 9.4 & 9.2 & 10.5 & 11.2 \\
\hline $\begin{array}{l}\text { Unskilled } \\
\text { workers }\end{array}$ & 15.8 & 15.9 & 16.8 & 15.2 & 14.7 & 19.1 & 18.6 & 17.7 & 19.5 & 20.6 \\
\hline
\end{tabular}

Source: INSEE (2014). INSEE T304

Persons aged 15 or older residing in metropolitan France in ordinary households

over the period 2008-2013. The unemployment rate in France was slightly lower than the EU average in $2012(10.6 \%)$, but higher than that of other destinations such as Germany (5.6\%) or the United Kingdom (8.0\%) (INSEE 2014).

Prior to the crisis, women had a more disadvantaged situation on the labour market than men (higher unemployment rates, lower salaries, more frequent part-time jobs). However as activity sectors most hit by the economic crisis employed more male workers (construction, temporary work placements...), men's employment has deteriorated to a greater extent. For example in 2008 men's unemployment rate was 0.7 points lower than that of women, but the situation has reversed by 2013 .

Young adults (15-24 years old) have been the age group most affected by the crisis. Their unemployment rate was significantly higher than average prior to the crisis (18.3\% in 2008) and has continued rising since then. In 2013, almost one in 
four active young people were unemployed (23.9\%). However this high level of unemployment partly reflects the specific situation of this age group as many individuals are still pursuing their studies and are not counted in the active population. Thus the proportion of unemployed among all 15-24 years old is significantly lower $(8.9 \%)$.

The increase in the unemployment rate has been highest for groups with low levels of human capital. It increased by 4.3 points between 2008 and 2012 for individuals with a less than secondary degree, whereas the rise was only by 1.1 points for those with a tertiary degree. Executive staff and intermediate occupations experienced low unemployment rates throughout the crisis (less than $4 \%$ and less than $5.2 \%$ in the period 2008-2013), whereas the unemployment rates of workers, and particularly unskilled workers, have risen.

\subsubsection{EU Migration to France: A Positive, But Limited Impact of the Economic Crisis}

\subsubsection{Stocks and Flows of EU Migrants in France}

After two decades of relatively low levels of migration flows, arrivals in France resumed at the end of the 1990s. At the start of the century, 200,000 migrants on average entered France every year (INED 1994-2008). As a result, the total immigrant population increased from 4.3 million in 1999 to 5.1 million in 2006 (Table 8.2). It has continued to increase in the last years, albeit at a lower rate. Since the end of the 1990s, growth in the immigrant population has mainly been fuelled by migration from outside Europe, primarily Africa and Asia. Conversely, the number of EU27 immigrants experienced only a small increase between 1999 and 2011 and their share in the total immigrant population declined from $41.5 \%$ to $32.6 \%$. However, since the beginning of the crisis, migration flows of EU27 nationals are on the rise: the annual number of entries went from an average of 65,000 in 20062008, to around 91,000 in 2012 (Eurostat 2014).

These changes are mainly due to an increase in the number of Southern European migrants since the beginning of the crisis (Brutel 2014). In the previous decades the number of Italian, Spanish and Portuguese immigrants residing in France had been declining due to a low number of entries, an increase in the number of returns to the country of origin and the ageing of the population. ${ }^{1}$ This can equally be observed for the first two groups in the period 1999-2011, whereas the number of Portuguese remained stable and then increased. However, since the start of the crisis, entries of Southern European migrants have increased and Portuguese migrants represented the largest proportion of migrants entering France in 2012 (8\%), surpassing

\footnotetext{
${ }^{1}$ Greek immigrants in France are not identified as a separate category in statistical sources due to low numbers. In the remaining sections they are grouped with "other EU27" nationals and the category of Southern European migrants only refers to migrants from Italy, Spain and Portugal.
} 
Table 8.2 Immigrant population by country of origin, 1999-2011

\begin{tabular}{|c|c|c|c|c|c|c|c|c|}
\hline & \multicolumn{3}{|l|}{ Total } & \multicolumn{3}{|c|}{$\%$ col } & \multicolumn{2}{|c|}{$\begin{array}{l}\text { Annual increase } \\
(\%)\end{array}$} \\
\hline & 1999 & 2006 & 2011 & 1999 & 2006 & 2011 & $\begin{array}{l}1999- \\
2006\end{array}$ & $\begin{array}{l}2006- \\
2011\end{array}$ \\
\hline EU27 & $1,786,087$ & $1,790,510$ & $1,826,766$ & 41.5 & 34.9 & 32.6 & 0.0 & 0.4 \\
\hline Spain & 316,544 & 269,647 & 245,013 & 7.3 & 5.2 & 4.4 & -2.3 & -1.9 \\
\hline Italy & 380,798 & 329,998 & 297,740 & 8.8 & 6.4 & 5.3 & -2.0 & -2.0 \\
\hline Portugal & 570,243 & 569,600 & 592,281 & 13.2 & 11.1 & 10.6 & 0.0 & 0.8 \\
\hline Greece & 10,157 & 9,496 & 9,683 & 0.2 & 0.2 & 0.2 & -1.0 & 0.4 \\
\hline Belgium & 93,395 & 103,263 & 111,264 & 2.2 & 2.0 & 2.0 & 1.4 & 1.5 \\
\hline Germany & 125,227 & 128,91 & 123,313 & 2.9 & 2.5 & 2.2 & 0.4 & -0.9 \\
\hline $\begin{array}{l}\text { United } \\
\text { Kingdom }\end{array}$ & 74,683 & 134,052 & 153,955 & 1.7 & 2.6 & 2.7 & 8.7 & 2.8 \\
\hline Poland & 98,566 & 90,426 & 92,769 & 2.3 & 1.8 & 1.7 & -1.2 & 0.5 \\
\hline Romania & 23,301 & 42,219 & 74,661 & 0.5 & 0.8 & 1.3 & 8.9 & 12.1 \\
\hline Other EU27 & 47,097 & 54,206 & 59,606 & 1.1 & 1.1 & 1.1 & 2.0 & 1.9 \\
\hline Third countries & $2,522,440$ & $3,345,784$ & $3,778,402$ & 58.5 & 65.1 & 67.4 & 4.1 & 2.5 \\
\hline Total & $4,308,527$ & $5,136,294$ & $5,605,167$ & 100 & 100 & 100 & 2.5 & 1.8 \\
\hline
\end{tabular}

Source: INSEE - Population census

Algerians and Moroccans (7\% each) (Brutel 2014). Spanish and Italian migrants accounted for $5 \%$ and $4 \%$ of entries.

The numbers of immigrants from Belgium and Germany have stayed relatively stable in the last decade, whereas there was an important increase of UK nationals (their number doubled between 1999 and 2011). Migration from Eastern and Central EU countries to France has remained limited compared to other destination countries, such as the UK, in part due to the introduction of transitional periods for nationals of the new Member States in 2004 and 2007 and the ensuing restrictions in their access to the labour market. The number of immigrants from EU8 countries, mainly Poland, remained stable during the last decade. Migration from EU2 countries, mainly Romania, started prior to their EU accession and has grown since their entry. The number of Romanians tripled between 1999 and 2011.

In the remainder of this section we compare the characteristics of recent migrants in the period prior to and after the start of the current economic crisis. ${ }^{2}$ As mentioned earlier, we observe an increase of the three groups of Southern Europeans since the crisis: in the period 2006-2011, the number of recent migrants from Southern

${ }^{2}$ France does not have a statistical source allowing direct monitoring of flows. In line with the national statistical institute (INSEE) that uses the population census to estimate flows and characteristics of migrants, we use the population census to describe this population (Brutel 2014). We define recent migrants as immigrants residing in France for less than 5 years. Since 2004 the population census is an "annual information collection covering all municipal territories in succession over a five-year period". Data for a given year (for example 2011) comprise information gathered over a 5-year period (2009-2013). We use the population census individual database [INDREG] for the years 2006 and 2011. 
Table 8.3 Number and distribution of recent migrants by country of origin, 2006-2011

\begin{tabular}{c|l|l|l|l|l}
\hline \multirow{2}{*}{} & \multicolumn{3}{l}{ Number } & \% col & Annual increase (\%) \\
\cline { 2 - 6 } & 2006 & 2011 & 2006 & 2011 & $2006-2011$ \\
\hline EU27 & 193,748 & 207,302 & 30.2 & 34.0 & 1.4 \\
\hline Spain & 11,948 & 16,387 & 1.9 & 2.7 & 6.5 \\
\hline Italy & 14,07 & 19,665 & 2.2 & 3.2 & 6.9 \\
\hline Portugal & 27,203 & 42,228 & 4.2 & 6.9 & 9.2 \\
\hline Belgium & 17,583 & 19,405 & 2.7 & 3.2 & 2.0 \\
\hline Germany & 21,177 & 17,515 & 3.3 & 2.9 & -3.7 \\
\hline United Kingdom & 52,283 & 34,974 & 8.2 & 5.7 & -7.7 \\
\hline Poland & 9,605 & 10,247 & 1.5 & 1.7 & 1.3 \\
\hline Romania & 11,287 & 19,746 & 1.8 & 3.2 & 11.8 \\
\hline Other EU27 & 28,594 & 27,135 & 4.5 & 4.4 & -1.0 \\
\hline Third countries & 447,22 & 403,198 & 69.8 & 66.0 & -2.1 \\
\hline Total & 640,968 & 610,500 & 100 & 100 & -1.0
\end{tabular}

Source: INSEE - Population census individual database [INDREG]. Authors' estimations Immigrants residing in France for less than 5 years

Europe living in France increased from around 53,000 to 78,000, with a particularly strong increase for Portugal $(+15,000)$ (Table 8.3). Although the number of recent migrants from the UK remains in second place, it has reduced compared to the period before the crisis. The number of Polish nationals remained stable, but we observe an increase in the number of recent migrants from Romania, albeit they still remain much lower than that from Portugal and the UK.

When analysing the characteristics of recent migrants from Southern Europe to France with regards to previous migration waves, it is important to keep in mind the historical development of each community and how much time separates the two waves of migration (see introduction). Flows of Italian guest workers had declined by the end of the 1960s and several decades had elapsed before recent migrants started arriving from Italy to France. The situation of Portugal is quite different to the extent that migration flows of workers had been declining prior to the country's EU accession, but that they had never fully stopped and thus current flows can be considered a continuation of these past waves. Spanish migrants are in an intermediate situation as their flows developed and declined later than that of Italians, but there is nevertheless more discontinuity between the two waves compared to the Portuguese case. The extent to which characteristics of recent migrants mirror those of past flows - low-skilled work migration, with a dominance of male migrants - or present new characteristics associated with EU migration - students, highly-skilled workers - largely depend on the history of each community. 


\subsubsection{Socio-demographic Characteristics of Recent Migrants in France}

EU migrants in France remain concentrated in the 25-44 age group in both periods, with the exception of UK nationals, but some differences can be observed since the crisis pointing to changes in the age composition of migration flows (Table 8.4). Around one in five Portuguese migrants are under the age of 15, thus pointing to an important family component. The corresponding proportion was lower for Italy and Spain in 2006 (11\% and 13\%), but increased by 2011 (16\% and $20 \%)$ suggesting that recent migrations more often comprise entire families and not only single adults. The proportion of 15-24 years old declines for Spain and Portugal, but also Poland and Romania. As this age group primarily consists of students, this may indicate that student mobility has diminished during the crisis due to a rarity of resources (institutional but also individual and family). In the case of EU10 nationals it also results from a diversification of profiles and the increase in economic migration since the end of the transitional period. Nationals from the UK and Belgium are on average older, with migrations often taking place for professional reasons at a later stage of the career or after retirement. Migrants in this age group remain relatively few among Southern Europeans, but their proportion has increased among the Portuguese (13\% in 2011 versus $9 \%$ in 2006).

After being a minority among the immigrant population throughout most of the twentieth century, women finally represented 51\% in 2008 (Beauchemin et al. 2013). Among recent migrants their proportion was higher: 53-54\% (Table 8.5). Portuguese migration has been male dominated since the beginning and the

Table 8.4 Age of recent migrants by country of origin, 2006-2011

\begin{tabular}{|c|c|c|c|c|c|c|c|c|c|c|c|c|}
\hline & \multicolumn{6}{|l|}{2006} & \multicolumn{6}{|l|}{2011} \\
\hline & -15 & $\begin{array}{l}15- \\
24\end{array}$ & $\begin{array}{l}25- \\
44\end{array}$ & $\begin{array}{l}45- \\
64\end{array}$ & $65+$ & Total & -15 & $\begin{array}{l}15- \\
24\end{array}$ & $\begin{array}{l}25- \\
44\end{array}$ & $\begin{array}{l}45- \\
64\end{array}$ & $65+$ & Total \\
\hline EU27 & 15.4 & 17.4 & 41.8 & 20.3 & 5.1 & 100 & 16.5 & 17.4 & 43.8 & 18.0 & 4.3 & 100 \\
\hline Spain & 13.0 & 23.8 & 52.8 & 8.2 & 2.2 & 100 & 20.0 & 19.8 & 49.2 & 9.7 & 1.3 & 100 \\
\hline Italy & 11.3 & 18.1 & 53.6 & 12.8 & 4.2 & 100 & 15.9 & 16.9 & 52.7 & 12.0 & 2.5 & 100 \\
\hline Portugal & 22.1 & 21.6 & 45.9 & 8.6 & 1.9 & 100 & 20.8 & 18.6 & 46.7 & 12.7 & 1.2 & 100 \\
\hline Belgium & 18.4 & 13.6 & 42.5 & 20.4 & 5.2 & 100 & 18.9 & 13.8 & 37.7 & 23.1 & 6.5 & 100 \\
\hline Germany & 13.5 & 21.6 & 46.4 & 15.2 & 3.3 & 100 & 14.3 & 21.5 & 45.1 & 16.0 & 3.1 & 100 \\
\hline $\begin{array}{l}\text { United } \\
\text { Kingdom }\end{array}$ & 15.3 & 6.6 & 27.3 & 39.9 & 10.8 & 100 & 13.9 & 9.3 & 26.5 & 37.5 & 12.8 & 100 \\
\hline Poland & 10.6 & 24.0 & 57.3 & 7.6 & 0.5 & 100 & 11.6 & 18.4 & 58.8 & 10.4 & 0.8 & 100 \\
\hline Romania & 11.0 & 26.2 & 54.9 & 6.8 & 1.0 & 100 & 14.7 & 21.9 & 53.5 & 9.0 & 0.9 & 100 \\
\hline $\begin{array}{l}\text { Other } \\
\text { EU27 }\end{array}$ & 15.1 & 23.5 & 39.7 & 17.7 & 4.0 & 100 & 14.5 & 21.3 & 42.3 & 17.2 & 4.6 & 100 \\
\hline $\begin{array}{l}\text { Third } \\
\text { countries }\end{array}$ & 16.3 & 26.5 & 48.6 & 7.2 & 1.2 & 100 & 14.6 & 26.9 & 50.1 & 7.2 & 1.1 & 100 \\
\hline Total & 16.0 & 23.8 & 46.6 & 11.2 & 2.4 & 100 & 15.3 & 23.7 & 48.0 & 10.8 & 2.2 & 100 \\
\hline
\end{tabular}

Source: INSEE - Population census individual database [INDREG]. Authors' estimations Immigrants residing in France for less than 5 years 
Table 8.5 Proportion of female migrants among recent migrants by country of origin, 2006-2011

\begin{tabular}{c|l|l}
\hline & 2006 & 2011 \\
\hline EU27 & 51.3 & 50.5 \\
\hline Spain & 54.6 & 51.1 \\
\hline Italy & 49.1 & 48.9 \\
\hline Portugal & 44.9 & 45.9 \\
\hline Belgium & 49.4 & 49.4 \\
\hline Germany & 52.4 & 53.4 \\
\hline United Kingdom & 48.9 & 49.7 \\
\hline Poland & 60.3 & 55.7 \\
\hline Romania & 56.4 & 51.8 \\
\hline Other EU27 & 56.6 & 55.8 \\
\hline Third countries & 53.9 & 55.9 \\
\hline Total & 53.1 & 54.1 \\
\hline
\end{tabular}

Source: INSEE - Population census individual database [INDREG]. Authors' estimations

Immigrants residing in France for less than 5 years

proportion of women remains low among recent migrants (45-46\%). On the contrary, the majority of Spanish migrants were female in 2006 (55\%), but since the start of the crisis their proportion had decreased (51\%) pointing to a larger emigration of male migrants. The recent migration flow from Italy has been balanced and does not appear to be affected by the crisis. Poland and Romania had the highest proportions of female migrants in 2006 (57-60\%), but they diminished by 2011 $(52 \%)$, possibly due to the decrease in student migration and the growing proportion of work migrants from these countries.

Southern Europeans represent two extremes in terms of educational levels among recent migrants in France, but we can observe a certain homogenization since the start of the crisis. A large majority of migrants from Portugal $(77 \%)$ had a less than secondary degree and only $8 \%$ had a tertiary degree in 2006 (Table 8.6). Conversely, the majority of migrants from Spain and Italy held a tertiary degree: $63 \%$ of Spaniards and $51 \%$ of Italians in 2006. Although these differences persist in the post-crisis period, we see some changes. The proportion of Portuguese migrants with a secondary education has progressed (19\% versus $15 \%)$, pointing to a new class of workers potentially hit by the crisis and thus deciding to emigrate. On the contrary, Spanish migrants with a less than secondary educational level are more represented in the recent period, thus suggesting the emigration of low skilled migrants compared to recent years. Italian migrants became increasingly holders of a tertiary education (56\% versus $51 \%$ ). 
Table 8.6 Educational level of recent migrants by country of origin, 2006-2011

\begin{tabular}{|c|c|c|c|c|c|c|c|c|}
\hline & \multicolumn{4}{|l|}{2006} & \multicolumn{4}{|l|}{2011} \\
\hline & $\begin{array}{l}\text { Less than } \\
\text { secondary }\end{array}$ & Secondary & Tertiary & Total & $\begin{array}{l}\text { Less than } \\
\text { secondary }\end{array}$ & Secondary & Tertiary & Total \\
\hline EU27 & 28.8 & 29.0 & 42.1 & 100 & 31.0 & 28.8 & 40.2 & 100 \\
\hline Spain & 12.8 & 24.7 & 62.5 & 100 & 16.8 & 24.2 & 59.0 & 100 \\
\hline Italy & 17.6 & 31.8 & 50.6 & 100 & 15.3 & 28.6 & 56.1 & 100 \\
\hline Portugal & 76.8 & 14.9 & 8.2 & 100 & 71.2 & 19.3 & 9.5 & 100 \\
\hline Belgium & 18.9 & 32.7 & 48.4 & 100 & 20.4 & 36.5 & 43.1 & 100 \\
\hline Germany & 13.4 & 37.5 & 49.1 & 100 & 12.0 & 37.9 & 50.1 & 100 \\
\hline $\begin{array}{l}\text { United } \\
\text { Kingdom }\end{array}$ & 30.9 & 26.4 & 42.7 & 100 & 26.1 & 26.4 & 47.6 & 100 \\
\hline Poland & 21.3 & 39.8 & 38.8 & 100 & 23.2 & 36.2 & 40.6 & 100 \\
\hline Romania & 30.5 & 32.4 & 37.1 & 100 & 35.3 & 32.7 & 32.1 & 100 \\
\hline $\begin{array}{l}\text { Other } \\
\text { EU27 }\end{array}$ & 14.6 & 33.0 & 52.4 & 100 & 17.6 & 31.6 & 50.8 & 100 \\
\hline $\begin{array}{l}\text { Third } \\
\text { countries }\end{array}$ & 41.9 & 26.1 & 32.0 & 100 & 37.1 & 26.8 & 36.1 & 100 \\
\hline Total & 38.0 & 27.0 & 35.1 & 100 & 35.1 & 27.5 & 37.5 & 100 \\
\hline
\end{tabular}

Source: INSEE - Population census individual database [INDREG]. Authors' estimations Immigrants residing in France for less than 5 years aged 15 years or older

\subsubsection{Labour Market Situation of Recent Migrants in France ${ }^{3}$}

When we compare the situation of recent migrants before and after the crisis, we observe an increase of their activity rates - 64\% in 2006 to $74 \%$ in 2011 - which may have resulted from a decrease of student migration and increase of workers (Table 8.7). By comparison, the activity rates of third country nationals did not change in the same period. The activity rates are generally lower for female migrants ( $56 \%$ in 2006 versus $72 \%$ of male among recent EU27 migrants), but women have also experienced a higher increase by 2011 (+10 versus +9 points).

EU27 migrants, particularly nationals of EU15 states, benefited from a more favourable situation in the labour market prior to the crisis (INSEE 2012). Although EU27 migrants remain less concerned by unemployment than third country nationals, they have also experienced an increase of this indicator in the last years (unemployment rate increased by 2 points). Spanish and Italian migrants show the largest increase of the unemployment rate $(+34 \%$ and $+30 \%)$, but it remains above average for Portuguese $(+13 \%)$. Conversely, it has decreased for Eastern Europeans, namely Polish $(-13 \%)$ and Romanians $(-15 \%)$, who faced a much worse situation in 2006.

\footnotetext{
${ }^{3}$ The sample sizes of recent Southern European migrants in the French Labour Force Survey are small (for instance, there are 1500 South European immigrants in the 2012 LFS survey, whatever their age and period of arrival). Thus, we use the population census to describe the labour market situation of recent migrants. However, the information provided in the population census does not allow estimating comparable indicators pertaining to this field to other data sources (for example unemployment rates according to ILO definition).
} 


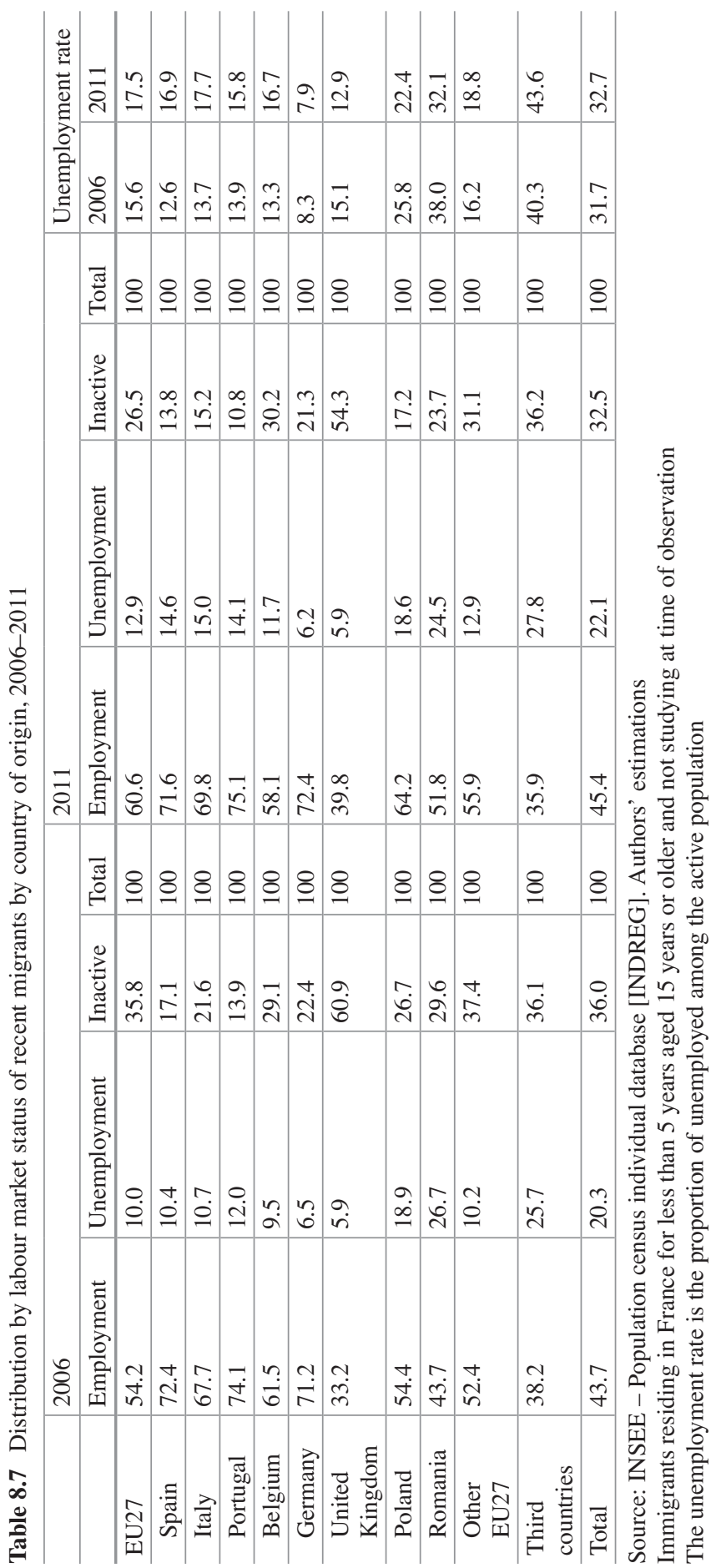


Table 8.8 Occupation level of recent migrants by country of origin, 2006-2011

\begin{tabular}{|c|c|c|c|c|c|c|c|c|}
\hline & \multicolumn{4}{|l|}{2006} & \multicolumn{4}{|l|}{2011} \\
\hline & Low & Mid & High & Total & Low & Mid & High & Total \\
\hline EU27 & 28.3 & 44.7 & 27.0 & 100 & 33.3 & 42.6 & 24.1 & 100 \\
\hline Spain & 15.0 & 48.6 & 36.5 & 100 & 19.3 & 47.7 & 33.0 & 100 \\
\hline Italy & 20.3 & 41.5 & 38.2 & 100 & 17.8 & 39.7 & 42.5 & 100 \\
\hline Portugal & 64.8 & 31.1 & 4.1 & 100 & 62.6 & 33.5 & 3.8 & 100 \\
\hline Belgium & 18.2 & 53.1 & 28.7 & 100 & 20.9 & 54.0 & 25.1 & 100 \\
\hline Germany & 14.6 & 49.3 & 36.2 & 100 & 13.0 & 49.5 & 37.5 & 100 \\
\hline United Kingdom & 16.9 & 50.0 & 33.1 & 100 & 19.2 & 47.5 & 33.3 & 100 \\
\hline Poland & 42.6 & 41.8 & 15.5 & 100 & 42.7 & 42.7 & 14.6 & 100 \\
\hline Romania & 37.5 & 45.0 & 17.5 & 100 & 40.5 & 39.2 & 20.3 & 100 \\
\hline Other EU27 & 16.2 & 47.4 & 36.4 & 100 & 22.3 & 44.7 & 33.0 & 100 \\
\hline Third countries & 41.3 & 44.1 & 14.6 & 100 & 36.5 & 44.0 & 19.4 & 100 \\
\hline Total & 35.8 & 44.4 & 19.9 & 100 & 34.9 & 43.3 & 21.8 & 100 \\
\hline
\end{tabular}

Source: INSEE - Population census individual database [INDREG]. Authors' estimations

Immigrants residing in France for less than 5 years aged 15 years or older and employed at time of observation

Low-level occupations refer to unskilled employees and labourers, including agricultural workers. Mid level occupations refer to intermediate professions, skilled employees, labourers and tradesman. High-level occupations refer to directors of companies of 10 or more employees and executives

The differences in terms of educational levels of Southern European migrants determine their occupation in the labour market. In recent decades Spanish and Italian migrants, similarly to North Western European migrants (Belgium, Germany, UK), are more likely to hold mid and high-level occupations (INSEE 2012); this is equally observed among recent migrants before and after the crisis (Table 8.8). Conversely, Portuguese have been concentrated in low-skilled occupations and this is still the case among recent arrivals (more than two thirds are in this category). Migrants from Central and Eastern Europe are in an intermediate situation.

However these profiles have changed for some groups in the period under study. Previously we observed a decrease in the educational level of Spanish migrants, and this is paralleled by an increase in the proportion of migrants in low-skilled occupations (+4 points). Conversely, among Italians who had already held the highest proportion of high-skilled occupations before the crisis, their proportion has further progressed and reached $43 \%$ in 2011. Although the census does not distinguish the holders of tertiary degrees, other sources point to the presence of a large number of Italian $\mathrm{PhD}$ holders in academic positions in France. Italians were the largest national group working in the National Centre for Scientific Research (332 in 2013, $19 \%$ of foreign researchers) (CNRS 2013). They also accounted for the largest number of recruitments of university professors in the last decade (371 between 2004 and 2013, $17 \%$ of recruitments of foreigners).

We also observe an increase in the occupational level of migrants from Romania, which may result from the fact that since the end of the transitional period, they are 
able to access a wider array of occupations. There has been a particularly high increase in the number of doctors born in Romania and practicing in France (176 in 2007, 840 in 2014) (CNOM 2014). This is also the only national group where female migrants have higher level of occupation than male migrants (32\% are highskilled versus $13 \%$ of male). For example, Romanian doctors in France are predominantly female $(71 \%)$.

\subsubsection{Posted Workers in France: More Southern European Working Under This Status Since the Beginning of the Economic Crisis}

The definitions and data sources used in the previous section allow identifying and describing a certain profile of EU migrants, i.e. those having changed their country of residence and currently residing in France. However this approach gives only a partial evaluation of the extent of crisis-induced immigration from Southern Europe to France for several reasons. Firstly, the population census is likely to underestimate the most recent migrants who may think of themselves as being temporarily in France and thus not concerned by the data collection, lack individual housing and not be identified by the census takers, be reluctant to participate given language problems, etc. Secondly, the population census does not cover specific profiles of migrants coming for a shorter duration in France, such as seasonal or temporary workers. Although the volume and characteristics of these migrants are by definition less known, different sources point to their increase since the beginning of the crisis.

Spaniards and Portuguese constituted the majority of workers recruited by the French Office for International Migration (OMI) to carry out seasonal activities in the 1960s and 1970s. After the entry of Spain and Portugal into the EU (1986) and the end of the transitional period (1992), Spanish and Portuguese workers obtained a direct access to the labour market and no longer had to go through the OMI recruitment process, thus disappearing from statistics on this type of workers. However, many of them continued working in seasonal jobs and commuting to France during certain periods of the year (Michalon and Potot 2008). Anecdotal evidence shows that their numbers have also risen since the start of the crisis, particularly in Southern regions of France (Picouët 2008; Millien 2014). The long-standing presence of workers from these countries in this sector may have facilitated their recruitment.

Another category of workers coming temporarily to France consists of posted workers, i.e. workers employed by companies based in other EU countries carrying out temporary services for companies or private employers in France (Math and Spire 2004). These workers in principle are not migrants, as they do not change their place of residence (UN definition). During the period of posting, workers hold a contract with their company based abroad and remain affiliated to the social security regime in the country where their company is established. Their stay in France is 
temporary, as most missions have a fixed duration, lasting from a few days to several months, which cannot exceed the maximal legal duration. ${ }^{4}$ Moreover these situations do not fall under the EU jurisdiction related to the freedom of movement to the extent that postings are regulated by the Directive 96/71/EC of 16 December 1996 concerning the posting of workers in the framework of the provision of services.

Despite this, characteristics and experiences of posted workers are similar to other groups of temporary migrant workers (Clark 2012). The process leading these workers to work abroad is also linked to limited economic opportunities in their home countries and their willingness to improve their living conditions. Although their missions have a limited duration and they are expected to return after each mission to their origin country, they can end up spending a relatively long time abroad, either when carrying out a mission lasting several months or by accumulating several shorter missions without returning. They occupy similar jobs to other migrants, such as low-skilled jobs in the construction sector or agriculture. Therefore, in many cases, it is only their legal status that differentiates them from other migrants, possibly putting them in a more vulnerable position despite their EU nationality (Math and Spire 2004). These considerations have led us to consider their case as an example of crisis induced work mobility in the EU, particularly given the fact that their presence in France has gained attention in the recent years and has triggered many debates (Sect. 8.3).

\subsubsection{Volume of Posted Workers in France}

The number of posted workers has grown continuously throughout the 2000s, going from around 16,000 in 2004 to around 213,000 in 2013 (Table 8.9). Even though part of this evolution is due to a better monitoring of these situations and the statistical coverage, which itself is a result of the growing attention this issue has raised in the recent years, it also indicates that an increasing number of EU nationals come to work in France under this regime. It is important to note that the term "posted workers" covers various types of postings - provision of services, temporary placement, intra-company transfers, self-employed - with different worker profiles in terms of nationalities, skill levels, working conditions, etc. The existing statistics do not

\footnotetext{
${ }^{4}$ The maximum legal duration for a posting is 24 months after which the worker no longer has the right to continue to be affiliated to the social security regime in the country of origin and must be registered in France.

${ }^{5}$ Companies posting workers in France have to make a declaration beforehand to the local work protection administration (number of workers, duration of posting, activity...). This information is compiled by the national work protection administration to produce annual statistics. These statistics do not estimate the number of workers coming to France a given year (flows) as the declaration covers a "service" (it may include several workers, workers may come to France several times during a given year, the duration of the presence in France of these workers varies). For a more detailed description of these statistics see Direction Générale du Travail (2014).
} 


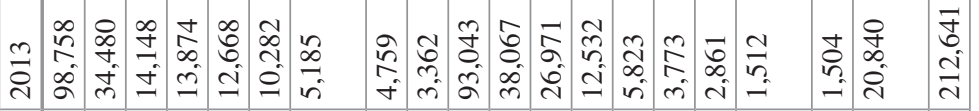

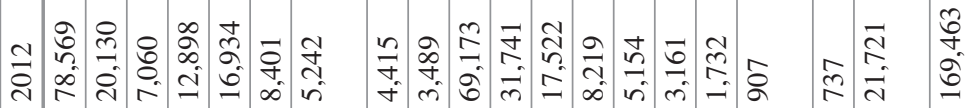

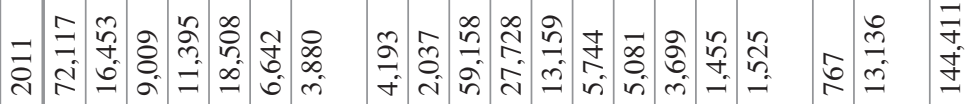

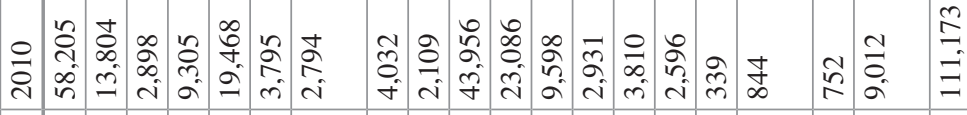

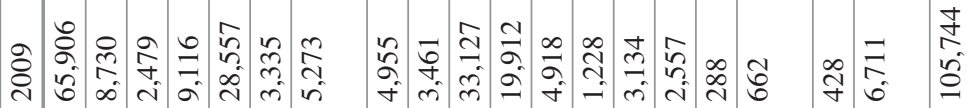

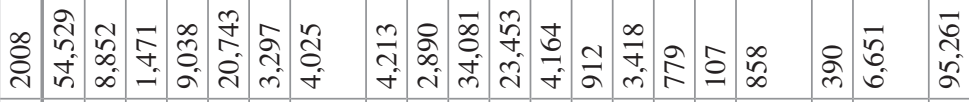

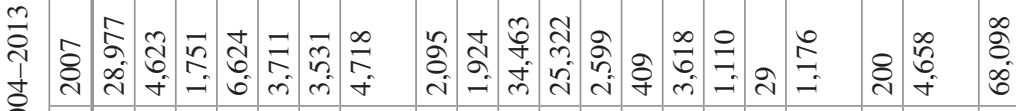

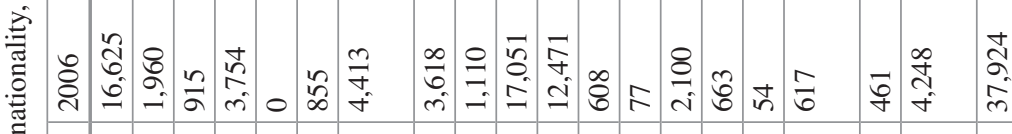

s

峁

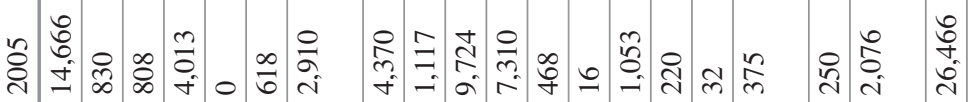

3

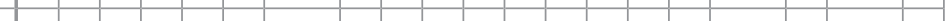

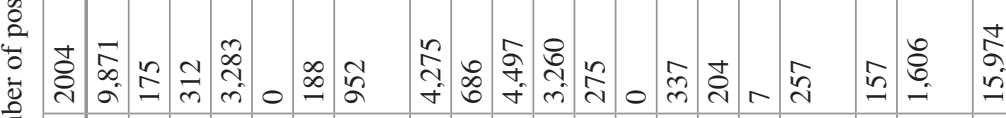


allow us to identify these different groups, although it is possible to make some assumptions as we describe below.

There has been an important change in the geographical composition of posted workers in France in the last decade. Historically posted workers were mostly highskilled workers from neighbouring countries: in 2004 almost half of posted workers came from just two countries, Belgium and Germany. Starting from the mid-2000s we see an increase in the number of EU10 nationals. In 2013 Polish workers represented the largest national group with around 38,000 workers, thus $18 \%$ of the total. The number of Romanian workers has also been rapidly increasing since 2009, reaching 27,000 workers in 2013 (13\% of the total). However since the beginning of the crisis, and particularly in the most recent years, the most important increases are seen in the numbers of Southern European workers. Between 2012 and 2013 the number of Portuguese progressed by $71 \%$. Portugal now has the second highest number of posted workers in France (34,000 workers in $2013,16 \%$ of the total) and although they remain the second largest group (after Poland), they were expected to surpass them in 2014. The number of Spanish workers doubled in 2013 and they became the fourth most numerous national group (after Poland, Portugal, Romania).

\subsubsection{Socio-economic Characteristics of Posted Workers in France}

The large majority of posted workers are concentrated in low-skilled occupations (86\% are labourers in 2013) (DGT 2014). Intermediate and high level professions accounted for $5 \%$ and $2 \%$ respectively, with the remaining proportion undetermined. Most posted workers are employed in construction (42\% in 2013), but there is also an important proportion of workers employed by temporary placement agencies covering different sectors $(23 \%)$, as well as workers in the industrial sector $(16 \%)$.

The regions of activity of posted workers in France have also evolved over the years. Up until the mid-2000s they were primarily concentrated in border regions in the East and North of France. With time however there has been a penetration over the entire territory, including the Ile de France region. The increase since the crisis has been stronger regions in the South, in regions bordering Spain and Portugal. In Aquitaine the number of posted workers has tripled since 2008 (whereas it has doubled in France), with most of the postings being declared by Spanish and Portuguese companies in the construction sector (DIRECCTE Aquitaine 2014).

\subsection{Policies and Debates in Focus}

Immigration has been a recurrent issue of French national debates in the 2000s and 2010s. These debates have mainly focused on flows from third countries in the South or from Eastern European countries, and only indirectly touched upon the case of Southern European countries. This section analyses the factors explaining 
this situation, focusing first on the history of immigration policy in France, then on the implementation of EU directives related to the freedom of movement and provision of services. The analysis of debates related to EU mobility and EU policy, precisely that on the Roma and on posted workers, underlines two characteristics of the recent debates on intra-European immigration in France: first of all, these debates started before 2008 and the economic crisis; second, these debates focused on Eastern Europeans, which in turn contributed to the invisibilizing of Southern Europeans in France.

\subsubsection{History of Immigration Policy in France}

The history of immigration policy in France can help explain why policies and debates today are not so much focused on immigrants from Southern Europe. The state has played a central role in managing immigration policy flows in France since the nineteenth century (Weil 1991; Noiriel 1996; Viet 1998; Guiraudon 2000). Immigration policy in France in the twentieth century is thus the result of the emergence and variations of three competing logics, each defended by a variety of administrations: a policing logic, with the objective of ensuring the safety of the territory through the control of borders and foreigners; a labour logic, with the objective of providing a sufficient labour force in times of need and in specific sectors, but limiting the presence of foreigners in times of economic crisis; and finally a logic of population, concerned with the role of immigration in the French population and its fertility, and at times tainted with racial undertones (Spire 2005). These three logics are often intertwined and difficult to disentangle in the resulting immigration policy.

These logics were all at play in the gradual favouring of European immigration over immigration from the former French colonies (mainly in West and North Africa). Immigration to France, initially mainly from Belgium, Italy and Poland, comprised more and more workers from the French colonies between the wars, as well as Spaniards. After the Second World War, the numbers of immigrants from the (former) colonies in Africa grew, in parallel with the number of Spaniards and Portuguese. While the slowing down of the economy at the end of the 1960s led to limitations in the entry of foreign workers, and eventually to the announcement of the end of labour migration in 1974, the preference for European migrants was reinforced with the progressive construction of a European market and the promotion of the free movement of workers and their families (Sect. 8.3.2). EU law effectively created a two-tier system of immigration by distinguishing EU nationals from "third-country nationals".

With the rise of colonial and postcolonial immigration (Sayad 1999), European immigration came to be considered as unproblematic, compared to that of other immigrants. Gérard Noiriel (1996) showed how successive waves of immigrants to 
France since the nineteenth century have all progressively been integrated within the French nation, by looking at their socio-economic status, their religious (or rather non-religious) beliefs and practices, as well as rates of inter-marriage. He also explained that debates on non-European immigrants developed along similar lines as earlier debates on Polish or Italian immigration, for example. This is why he expected the integration of non-European immigrants to follow the same path.

However, this narrative has been questioned by accounts that underline the specific treatment of postcolonial immigration, as well as the later development of racist, xenophobic and more recently anti-Muslim discourses in France (Blanchard 2005; Boubeker 2005; Boubeker and Hajjat 2009). The public debate has very much followed a "logic of population" and been framed in terms of "integration", defined on the basis of the French model of citizenship (Brubaker 1998). In this framework, extra-European immigration is considered more "problematic" than European immigration, including when the arrival of different migrants actually coincided in time (as is the case with the Portuguese for example). The differential treatment of European and non-European immigrants is thus institutional and systemic, as has been shown by the literature on postcolonial immigration and on discriminations (see for example De Rudder et al. 2006), and as induced by the process of European integration. It is also part of the everyday economic and social life of immigrants, as shown in the higher employment rates of European immigrants compared to nonEuropeans in France (Simon and Steichen 2014). They also tend to occupy different jobs: in the construction sector, for example, Portuguese workers are given supervising positions, while immigrants from Africa and North Africa are usually assigned subaltern tasks (Jounin 2009). This is symptomatic of the privileged position of European immigrants in France compared to other immigrants, and of the progressive invisibilizing of these immigrants (Cordeiro 1999).

We argue that political debates on intra-European immigration, while singling out Eastern Europeans, have reinforced this dynamic and made Southern European immigration even less visible. Most policies and debates in the last decades continue to target extra-European immigrants. However, economic concerns and competition in the labour market were also part of these debates, as is visible in campaigns of the extreme-right Front National against immigration. In the 2000s and 2010s, both before and after the crisis, these concerns also affected the debate on intra-European migration. European migrants came to the fore on various occasions and mostly in relation to debates on the EU's enlargement and to the question of social protection and rights for workers.

\subsubsection{Controlling the Access to the Labour Market in a Context of Free Movement}

One of the ways in which intra-European immigration was favoured in France was through European integration. As early as 1957, the Treaty of Rome introduced the idea of a free movement of people, more specifically of workers, between European 
countries. However, the construction and implementation of free movement was progressive: the national legal norms transposing this right were only elaborated at the end of the 1960s (right of establishment of workers and their families, coordination of social security regimes...) and discriminations towards workers from Member States persisted until the 1990s (Rodier 2001; Math 2004). Despite this, limitations on social security or pension benefits, as well as most limitations on access to some occupations (for civil service for example) were progressively removed.

As a result, the labour markets of member States became almost completely open to nationals of other Member States. However political moves were made to protect national labour markets, particularly at the time of every EU enlargement. Higher salary and social protection levels in "older" Member States were often seen as overly attractive to workers of "new" Member States, whose citizens would then constitute unfair competition for national workers. This led to the adoption of socalled "transitional periods" for new Member States, during which migrants coming from these countries benefited from free movement, but could not directly take up salaried work and had to ask for a provisional authorisation to do so. In 1986, France introduced the maximum transitional period for Spanish and Portuguese workers limiting their access to the French labour market for 7 years. During the recent enlargements towards Central and Eastern Europe, France introduced a transitional period of 5 years, later reduced to four, for EU8 members states (May 2004June2008), ${ }^{6} 7$ years, the maximum authorized duration, for Romania and Bulgaria (January 2007-December 2013) and 2 years for Croatia (July 2013-June 2015).

This meant that the European Union was not a two-tier system distinguishing between EU nationals and non-EU nationals (or third country nationals), but rather a variable geometry system of borders for protecting national labour markets. In fact the system is three-tier: "ethnic migrants" from outside the EU are considered the most visible and raise concerns about integration and multiculturalism, while "free movers" or "Eurostars", as nationals of pre-2004 Member States, enjoy freedom of movement and establishment since a long time. "East-West migrants" from the Member States having accessed the EU in the 2000s, fall in between these two categories: while they enjoy the freedom of circulation, and are given the freedom to work in all EU Member States after the end of the transitional period, they are still considered as "immigrants" rather than "free movers" (Favell 2009). In spite of the transitional period of new Member States coming to an end, the political debate on intra-EU immigration and the labour market has remained very much focused on nationals from these States, even though Romania came in third position as an immigration-sending country to France in the recent period, after Portugal and the UK, and Poland in eighth position, way behind Spain, Italy or Germany (see Sect. 8.2.2).

This focus has been particularly visible in two recent debates. First, the debate on the non-French Roma population culminated in 2010, when the French President,

\footnotetext{
${ }^{6}$ Among the 2004 accession countries, Malta and Cyprus were not covered by the temporary restrictions.
} 
Nicolas Sarkozy, announced the dismantling of camps and squats, and the deportation of their foreign inhabitants to their origin countries within the EU. Although this policy was influenced by a long history of institutional racism towards the Roma in France, it also raised an array of arguments relating to free movement and the differences in social protection systems in the EU. Second, the debate on the Directive on services, also known as the "Bolkestein directive", addressed the issue of posted workers prior to the 2008 economic crisis and reemerged in recent years. In both instances, in spite of their focus on Eastern Europeans, political debates contributed to shaping political discourses as well as policies towards intra-European immigration and as such have had an impact on policies regarding Southern European immigration.

\subsubsection{Anti-Roma Feeling and the Issue of Social Protection in the French Debate on Intra-European Migration}

In 2010 the debate over Roma presence in France and the circulation of Roma EU-citizens within the European Union made the headlines in France and abroad. Indeed, after a gendarme killed a young French Roma and the following attack of a police station by dozens of armed French Roma, Nicolas Sarkozy, then President of the country, announced the dismantling of 300 illegal camps and squats within 3 months. ${ }^{7} \mathrm{He}$ also declared that those found to be living in France "illegally" would be sent back home. His speech particularly targeted Romanian and Bulgarian Roma, who had already been victims of France's quantitative objectives for deportations in the previous years. However, this announcement, by singling out a population along ethnic lines and by publicizing the deportation of EU citizens, attracted harsh criticisms. EU Justice Commissioner Viviane Reding took a stand against these deportations, and the European Commission warned France that it had two weeks to implement the 2004 EU directive on freedom of movement or it would face an infringement procedure. Although the Commission did not pursue an infringement procedure, Viviane Reding deplored the fact that some policies appeared to target and single out Roma populations, thus violating EU anti-discrimination directives as well as the European Charter of Fundamental Rights.

Although anti-Roma feeling is not new, national and local policies have exacerbated it in the recent years (Fassin et al. 2014). The existence of a form of "welfare tourism" has been one of the central arguments to justify these policies, particularly the deportation of Roma citizens back to Romania and Bulgaria (Nacu 2012).

Despite the fact that the EU Directive on free movement stipulates that recourse to social assistance cannot be a valid ground for expelling an EU national, French law allows the expulsion of EU nationals who have the "primary objective of benefitting from the social assistance system" (Dimitrova 2013). Thus, following a

\footnotetext{
${ }^{7}$ Nicolas Sarkozy, Speech in Grenoble, 30 July 2010.
} 
period of opening access to social protection (see Sect. 8.2.2), restrictive conditions were reintroduced for some social benefits prior to the first EU enlargement towards Central and Eastern Europe: the Revenu Minimal d'Insertion (RMI) (or RSA, Revenu de Solidarité Active since 2008), as well as the allocation for single parents (API) and for the handicapped (AAH), which all include requirements of a minimum period of residence before they can be claimed. Although many of these changes and debates mostly concern extra-European immigrants, their timing suggests that they also targeted intra-EU immigration. The selective implementation of certain provisions also shows that specific groups of migrants were targeted. For example, the conditions to claim family benefits were modified in 2012 to include a provision stating that persons having been the object of an official prefectural decision (deportation, non-renewal of residence permit for nationals with a transitional regime, beneficiaries of a financial aid in the case of return to country of origin) could not benefit from them (Demagny and Math 2014). Prior to this change, expulsions of EU nationals with insufficient resources had been disproportionately exercised against Romanian nationals (European Parliament 2009), who were therefore the most likely to be concerned by this condition. However, these changes are, in principle, for all EU migrants in France, and the restrictions on access to social revenues affect all of them.

\subsubsection{From the "Polish plumber" to Posted Workers: The French Debate on the "Bolkestein Directive"}

As was described earlier in this chapter, an increasing number of EU nationals, particularly Southern Europeans, are coming to work in France as posted workers. These workers did not attract much attention at first (the first EU directive regulating their movement dates back to 1996) as their status was considered a quite technical issue, and mostly of interest for trade unions, labour inspections and lawyers. However, posted workers surprisingly became the centre of a heated debate in France in 2004 and 2005 after the European Commission issued a proposal for a Directive on services in the internal market, also known as the "Bolkestein Directive" (after Commissioner Frits Bolkestein). After the proposal was amended, the issue of posted workers once again "disappeared", although some cases of postings made the headlines on a periodical basis. However with the rise of posted workers in the context of the current economic crisis, this issue came once again at the forefront of debates regarding social and economic EU policies.

Within the more general framework of the Directive 96/71/EC on the posting of workers the Bolkestein Directive aimed at reducing national regulations on the provision of services. First, it provided a framework to facilitate the permanent establishment of foreign services providers in another Member State (this point was not particularly central in the debates). Second, through the "country of origin principle", the proposal aimed at facilitating the free movement of workers on a tempo- 
rary basis (Grossman and Woll 2011). This point proved particularly difficult to articulate with the protections offered by the existing 1996 directive. In particular, by "abolishing many administrative regulations and obligations for posting workers abroad, as well as transferring the competence for controls to the country of origin, the draft Services Directive was to create a de facto situation in which controls on labour law would have been even more difficult than they already were". The "country of origin" principle also implied "that a services provider who crosses the border to offer a service in another EU country has to abide solely by the rules of its Member State of origin, i.e., where it is formally established" (Crespy 2010: 1255).

The "country of origin" principle raised debates and mobilisations in various Member States (culminating in a march of almost 100,000 people in Brussels in March 2005 to protest against the directive), but nowhere as intense as in France. The French outrage over the Bolkestein directive and the country of origin rule cannot be understood without a closer look at the timing of the debate. Indeed, the Bolkestein directive provided opponents to European enlargement and integration with ammunition to bolster their position. In 2004, the Eastern enlargement round and its consequences - a more unequal European economic area - dominated discussions on Europe. Enlargement, as well as discussions for the potential accession of Turkey, made many weary of the competition of workers from new Member States. Moreover, in 2005, the European Constitutional Treaty, which was ultimately rejected by referendum in France was central to French political debates. In this context, the Bolkestein proposal was turned into the symbol of the tensions between the EU as an economic, market-oriented project on the one hand, and the idea of a "social Europe" on the other.

The figure of the "Polish plumber" came to embody the fears related to the directive on services and the enlargement. After Philippe de Villiers, the head of the right-wing party Mouvement pour la France, used this image in a speech against the directive in March 2005, it became very popular, including in other European countries - although the Germans were more concerned about butchers (Nicolaïdis and Schmidt 2007; Grossman and Woll 2011). The idea behind this figure was that workers from new Member States, with less stringent labour regulations, would come to work in older Member States and constitute a form of "social dumping" and thus unfair competition (Crespy 2010). However, the use of this image shows that fears about the directive on services were not only about the content of the directive, but also about the ongoing enlargement process. In the end, European governments revised the draft directive, suppressing the country of origin principle, but replacing it with a very similar article. It forbids protectionist barriers on the provision of services, unless they are non-discriminatory, justified by public interest and proportionate.

Thus, despite the initial opposition to the directive, it was nevertheless adopted, although in a slightly watered-down version, and the issue of posted workers has regularly reappeared in the French public debate ever since. Before the 2014 European elections, for example, extreme-right and extreme-left parties brought the issue of the misuse of posting to the forefront of debates (Balbastre 2014; Gatinois 2014). During a strike of truck drivers in March 2015 the French media covered the 
misuse of posted workers by transportation companies based in Central and Eastern European countries. A recent trial regarding the misuse of Romanian and Bulgarian posted workers for the construction of a nuclear reactor between 2008 and 2011 also attracted national coverage. All these events have sustained a European and national political attention on this issue. ${ }^{8}$ The Court of Auditors, the institution controlling State finances in France, has singled out fraud in the use of posted workers, and estimated the amount of foregone contributions to 380 million Euro (Cour des Comptes 2014). After the adoption of an EU directive facilitating the control of posted workers in 2014, ${ }^{9}$ these possibilities were rapidly transposed into French legal norms ${ }^{10}$ to fight against unfair competition (CNLTI 2015). These laws increase the legal and regulatory provisions in the fight against the misuse of the system (administrative sanctions in case of non declaration of posting, blacklisting of firms convicted, extension of the right of action of trade unions and professional organizations, solidarity of developers and project managers). There is also an important reorganization of the control mechanisms for identifying and pursuing frauds concerned with this system (greater coordination between different ministries in charge and development of joint controls by multiple institutions such as police, labour inspectors, customs; special monitoring service dealing with complex frauds).

\subsubsection{Invisible Southern European Migrants?}

Despite their growing numbers in France, Southern Europeans have been relatively absent from recent debates on EU mobility in France, which have on the contrary mainly focused on Central and Eastern European immigration from the most recent Member States. This situation has had contrary effects on the situation of Southern Europeans.

On the one hand, the changes in the legislation regarding access to the labour market, access to social benefits, the regulation of posted workers, now affect all European immigrants, including Southern Europeans, for better or for worse. The on-going debates on the access to the social security system, though not primarily

\footnotetext{
${ }^{8}$ Government reports mention the dangers of posted workers. See for example Le Guen (2005) for the use of posted workers in the agricultural sector. The Commission of European Affairs of the National Assembly (Grommerch 2011) and of the Senate (Bocquet 2013) also turned their attention to this issue and were both concerned with improving the regulation and control of posted work.

${ }^{9}$ Directive 2014/67/EU of the European Parliament and of the Council of 15 May 2014 on the enforcement of Directive 96/71/EC concerning the posting of workers in the framework of the provision of services and amending Regulation (EU) No 1024/2012 on administrative cooperation through the Internal Market Information System ('the IMI Regulation').

${ }^{10}$ Loi $n^{\circ} 2014-790$ du 10 juillet 2014 visant à lutter contre la concurrence sociale déloyale (also called "Loi Savary"). The recent Loi n² 2015-990 du 6 août 2015 pour la croissance, l'activité et l'égalité des chances économiques (also called "Loi Macron") also includes provisions on this topic.
} 
directed at Southern European migrants also concern them. The complexity of the administrative procedures and conditions to access certain social benefits (Demagny and Math 2014) and the increased risks of unemployment in the context of the current economic crisis, result in some of them having difficults in fulfilling residence requirements in France (Le Progrès 2014). The posted worker regime under which many of them work also raises questions as to their working conditions and social rights. Given the complexity of the status, it may be difficult for these workers and their families to access certain social rights, such as unemployment or family benefits, whether in France or in their country of origin.

On the other hand, the focus of debates on Central and Eastern European immigration have contributed to the invisibilizing of Southern European immigrants. Indeed one could argue that the visibility of Eastern and Central European migrants contributed in a way to the relative political invisibility of Southern European ones. However, it is difficult to establish a causal link here. Eastern and Central Europeans also generated more debates because they were nationals of the newest Member States. Thus these debates are as much related to the enlargement process and the growing Eurosceptic sentiment in France as they are to debates on immigration. By retracing the differential treatment of Southern European and extra-European immigrants in the media and in political debates, we can see how the debates on Central and Eastern European immigration fit in the longer-term dynamics of political debates on immigration in France.

Indeed, as was described above, debates on immigration in France focus mainly on extra-European immigration, and have made intra-European immigration comparatively less visible. The rise of debates on Central and Eastern European immigration thus came at a moment when the process of making immigrants from older Member States less visible in France was already under way. Thus, in line with Adrian Favell's typology of immigrants (described above in Sect. 8.3.1), their position has been intermediate: for a while, this was mainly the consequence of restrictions on their freedom to work in other Member States, during the transitional period. However, once legal restrictions were lifted, the political debate on intraEuropean immigration continued to focus on Central and Eastern immigrants, in spite of the relatively high numbers of Southern European immigrants in France. Although the debates and the ensuing restrictions affect all EU immigrants to France, the framing of the two debates discussed in this chapter, on posted workers and on welfare tourism, also paradoxically contributed to the on-going process that made Southern European immigrants less visible in France and thus more accepted than other groups of migrants.

\subsection{Conclusion}

Southern European migration and the entailing issues raised by these flows have not emerged in France, contrary to other destination countries analysed in this book such as Germany and the UK. Did this situation result from their absence or their general acceptance in French society? Our chapter shows that given its economic 
situation, France indeed did not attract as many Southern European migrants as neighbouring countries. In spite of this, we do observe changes in the volumes and composition of flows since the start of the economic crisis: a larger number of entries of Southern Europeans, new profiles of migrants, such as families with children. Moreover, the economic crisis and the more limited opportunities for companies in Southern Europe, especially in Spain and Portugal, combined with the search for cost reduction by companies in France, have supported the growth of the posted worker system. Although this system is not new and concerned primarily Eastern European workers up until the crisis, the recent increase in numbers of posted workers is partly due to the increased participation of Southern Europeans in this sytem.

Yet, in spite of the growing numbers of Southern European workers in France since the beginning of the economic crisis, the political debate has mainly focused in France on (1) extra-European immigration; (2) specific categories of intraEuropean immigrants, namely the Roma, as well as posted workers from the newest Eastern European Member States. Debates in this respect have mainly concentrated on issues of unfair competition on the labour market and "welfare tourism". While the legal and political consequences of these debates affect Southern European workers in France, the focus on Eastern Europeans has also contributed to make Southern Europeans less visible and their presence even less controversial to the eyes of many in France.

Acknowledgement This chapter is based on results from the TEMPER project (Temporary versus Permanent Migration, under grant agreement no. 613468) funded by the European Union's Seventh Framework Programme.

\section{References}

Balbastre, G. (2014, April). Travail détaché, travailleurs enchaînés. Le Monde Diplomatique.p. 12. Beauchemin, C., Borrel, C., \& Régnard, C. (2013). Les immigrés en France: en majorité des femmes. Population \& Sociétés, 502.

Blanchard, P. (2005). La France, entre deux immigrations. In N. Bancel, P. Blanchard, \& S. Lemaire (Eds.), La fracture coloniale (pp. 173-182). Paris: La Découverte.

Bocquet, E. (2013). Le travailleur détaché: un salarié low cost ? Les normes européennes en matière de détachement des travailleurs. Rapport d'information $\mathrm{n}^{\circ} 527$ fait au nom de la commission des affaires européennes, Sénat.

Boubeker, A. (2005). Le « creuset français », ou la légende noire de l'intégration. In N. Bancel, P. Blanchard, \& S. Lemaire (Eds.), La fracture coloniale (pp. 183-190). Paris: La Découverte.

Boubeker, A., \& Hajjat, A. (2009). Histoire politique des immigrations (post)coloniales. France, 1920-2008. Paris: Editions Amsterdam.

Brubaker, R. (1998). Citizenship and nationhood in France and Germany. Cambridge, MA: Harvard University Press.

Brutel, C. (2014). Les immigrés récemment arrivés en France. Une immigration de plus en plus européenne. Insee Première, 1524.

Centre National de la Recherche Scientifique (CNRS). (2013). Bilan social des personnels. Paris: CNRS.

Clark, N. (2012). Regulation and enforcement of posted workers' employment rights. National report: UK Working Lives Research Institute. 
Commission nationale de lutte contre le travail illégal (CNLTI). (2015). Bilan du plan national de lutte contre le travail illégal (PNLTI) 2013-2015.

Conseil National de l'Ordre des Médecins (CNOM). (2014). Les flux migratoires et trajectoires des médecins. Situation en 2014.

Cordeiro, A. (1999). Les Portugais, une population « invisible »? In P. Dewitte (Ed.), L'immigration, l'état des savoirs (pp. 106-111). Paris: La Découverte.

Cour des Comptes. (2014). Rapport sur l'application des lois de financement de la sécurité sociale. France: Cour des Comptes.

Crespy, A. (2010). When 'Bolkestein' is trapped by the French anti-liberal discourse: A discursiveinstitutionalist account of preference formation in the realm of European Union multi-level politics. Journal of European Public Policy, 17(8), 1253-1270.

De Rudder, V., Vourc'h, F., Fassin, D., \& Fassin, E. (2006). Les discriminations racistes dans le monde du travail. In De la question sociale à la question raciale? Représenter la société française (pp. 175-194). Paris: La Découverte.

Debauche, E., Arnaud, F., \& Laurent, T. (2015). Les comptes de la Nation en 2014. Insee Première, 1549.

Demagny, B., \& Math, A. (2014). Les citoyens européens: 10 situations de droits sociaux et de droit au séjour. Gisti.

Dimitrova, S. (2013). The illegality of France's expulsions of Bulgarian and Romanian Roma under European Union Law. Revue québécoise de droit international, 26(1), 33-61.

Direction Générale du Travail (DGT). (2014). Analyse des déclarations de détachement des entreprises prestataires de services en France en 2013.

DIRRECTE Aquitaine. (2014). Les détachements de salariés étrangers. Etat des lieux en Aquitaine 2012-2013. Etudes, 28.

European Parliament. (2009). Report on the application of Directive 2004/38/EC on the right of citizens of the Union and their family members to move and reside freely within the territory of the Member States. European Parliament, Committee on Civil Liberties, Justice and Home Affairs.

Eurostat. (2014). Immigration by five year age group, sex and citizenship [migr_imm1ctz]. http:// appsso.eurostat.ec.europa.eu/nui/show.do?dataset=migr_immlctz\&lang=en. Accessed 6 July 2014.

Fassin, E., Fouteau, C., Guichard, S., \& Windels, A. (2014). Roms et riverains. Une politique municipale de la race. Paris: La Fabrique.

Favell, A. (2009). Immigration, migration, and free movement in the making of Europe. In J. T. Checkel \& P. J. Katzenstein (Eds.), European identity (pp. 167-189). Cambridge: Cambridge University Press.

Gatinois, C. (2014, April 16). Le Pen dénonce un texte européen « criminel » sur les travailleurs détachés. Le Monde.

Grommerch, A. (2011). Rapport d'information de Mme Anne Grommerch déposé par la commission des affaires européennes sur le détachement des travailleurs. Paris, Assemblée Nationale. Commission des affaires européennes.

Grossman, E., \& Woll, C. (2011). The French debate over the Bolkestein directive. Comparative European Politics, 9(3), 344-366. doi:10.1057/cep.2010.19.

Guiraudon, V. (2000). Les politiques d'immigration en Europe: Allemagne, France, Pays-Bas. Paris: Editions L'Harmattan.

Institut National d'Etudes Démographiques (INED). (1994-2008). Statistiques sur les flux d'immigration - série 1994-2008. http://statistiques_flux_immigration.site.ined.fr/fr/. Accessed 6 July 2014.

Institut national de la statistique et des études économiques (INSEE). (2012). Immigrés et descendants d'immigrés en France - Insee Références - Édition 2012. Paris: INSEE.

Institut national de la statistique et des études économiques (INSEE). (2014). Tableaux de l'Économie Française - Édition 2014. Paris: INSEE.

Jounin, N. (2009). Chantier interdit au public. Enquête parmi les travailleurs du bâtiment. Paris: La Découverte. 
Larrieu, S., Biausque, V., Zakhartchouk, A. (2014). L'économie française tourne encore au ralenti en 2013. In L'économie française - Comptes et dossiers - Insee Références - Édition 2014 (pp. 19-45). Paris: INSEE.

Le Guen, J. (2005). L'impact de la concurrence sur l'emploi dans le secteur agricole. Etude comparée au niveau européen. Rapport au Premier ministre.

Le Progrès. (2014, July 14). Crise au Portugal: ils reviennent tenter leur chance dans le Haut-Jura. Le Progrès.

Math, A. (2004). Prestations familiales et regroupement familial. L'accès aux droits sociaux des familles étrangères contrarié par les politiques migratoires. In Les familles à la croisée de l'espace et du temps - Usages sociaux du temps et migrations, Actes de la conférence européenne, Comité économique et social européen, Bruxelles 12-13 January 2004 (pp. 113-134).

Math, A., \& Spire, A. (2004). Vers une immigration permanente de travailleurs temporaires. Du mode 4 de l'AGCS aux différents régimes migratoires de travailleurs détachés. Noisy-leGrand: IRES.

Michalon, B., \& Potot, S. (2008). Quand la France recrute en Pologne. Réseaux transnationaux et main-d'œuvre agricole. Etudes rurales, 182(2), 87-102.

Millien, E. (2014, July 2). La vigne plutôt que le chômage en Espagne. Sud Ouest.

Nacu, A. (2012). From silent marginality to spotlight scapegoating? A brief case study of France's policy towards the Roma. Journal of Ethnic and Migration Studies, 38(8), 1323-1328. doi:10. 1080/1369183X.2012.689192.

Nicolaïdis, K., \& Schmidt, S. K. (2007). Mutual recognition 'on trial': The long road to services liberalization. Journal of European Public Policy, 14(5), 717-734. doi:10.1080/13501760701427904.

Noiriel, G. (1996). The French melting pot: Immigration, citizenship, and national identity. Minneapolis: University of Minnesota Press.

Picouët, M. (2008, August 8). Des chômeurs du BTP espagnol reviennent vendanger en France. Le Monde.

Rodier, C. (2001). Les grandes étapes de la construction de l'« espace européen » de Rome à Amsterdam en passant par Schengen. Plein Droit, 4.

Sayad, A. (1999). La Double Absence. Des illusions de l'émigré aux souffrances de l'immigré. Seuil.

Simon, P., \& Steichen, E. (2014). Slow motion. The labor market integration of new immigrants in France. MPI.

Spire, A. (2005). Etrangers à la carte: L'administration de l'immigration en France. Paris: Grasset.

Viet, V. (1998). La France immigrée. Construction d'une politique 1914-1997. Paris: Fayard.

Weil, P. (1991). La France et ses étrangers. L'aventure d'une politique de l'immigration de 1938 à nos jours. Paris: Gallimard.

Open Access This chapter is licensed under the terms of the Creative Commons AttributionNonCommercial 2.5 License (http://creativecommons.org/licenses/by-nc/2.5/), which permits any noncommercial use, sharing, adaptation, distribution and reproduction in any medium or format, as long as you give appropriate credit to the original author(s) and the source, provide a link to the Creative Commons license and indicate if changes were made.

The images or other third party material in this chapter are included in the chapter's Creative Commons license, unless indicated otherwise in a credit line to the material. If material is not included in the chapter's Creative Commons license and your intended use is not permitted by statutory regulation or exceeds the permitted use, you will need to obtain permission directly from the copyright holder.

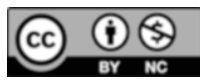




\title{
Chapter 9 \\ Gastarbeiter Migration Revisited: \\ Consolidating Germany's Position \\ as an Immigration Country
}

\author{
Amanda Klekowski von Koppenfels and Jutta Höhne
}

\subsection{Introduction}

An emerging trend has solidified after the 2008 economic crisis: Germany is, thanks to substantial Southern European migration, once again a key migrant-receiving country - and, more importantly, now sees itself as such. Positive net migration from Southern Europe was reached in 2010 for the first time since 1996, after increases since 2006. This post-crisis flow of EU migrants from Southern Europe to Germany bears a strong resemblance to the post-war Gastarbeiter (guest worker) migration. Then, however, an economic crisis ended the bi-lateral agreements; today, a crisis has re-initiated this migration, albeit a more highly-skilled flow than in post-war years. This chapter will argue that the post-crisis migration - and, above all, the targeted recruitment which is a key component of that migration - has confirmed Germany's position as an immigration country, not only in Europe, but internationally.

This chapter will draw on both quantitative and qualitative data to do so. It will, first, review the socio-economic situation in Germany, and, second, look at data trends of migration to Germany since 2000, when Germany first declared itself an immigration country. Third, the chapter will compare contemporary Southern European migration flows to that of post-war Gastarbeiter migration. This section will also argue that contemporary migration must be seen against the backdrop of other migration flows to Germany - not only Gastarbeiter, but also post-war flows of German expellees from Eastern Europe, asylum seekers, flows from the German

\footnotetext{
A. Klekowski von Koppenfels ( $\square)$

Brussels School of International Studies, University of Kent, Brussels, Belgium

e-mail: ak248@kent.ac.uk

J. Höhne

Institute of Economic and Social Research (WSI), Düsseldorf, Germany 
Democratic Republic and, finally, Aussiedler, or ethnic German migrants from Eastern Europe.

Finally, the chapter will turn to contemporary debates over migration. In addition to other ongoing migration and refugee flows, these include continuing discussions about migrant integration - with Turkish migrants and their children usually the focus of that discussion. Above all, however, this chapter argues that the discourse in Germany today is that of a consolidated immigration country - one where immigration as a phenomenon is widely accepted, and public discussions over type, profile and number of migrants are part of public debate as they are in the United States, Canada or Australia.

\subsection{Socio-economic Situation in Germany (2000-2014)}

By mid-2008, Germany was among the economies hit hardest by recession. Because of the country's strong export dependency, GDP fell sharply by $5.6 \%$ in 2009, an even stronger fall than the average European decline of $4.4 \%$. As a reaction to the crisis, the German Federal Government introduced a set of direct and indirect measures meant to secure and create employment and other business support instruments (stimulus packages 1 and 2) in November 2008 and January 2009, followed by a third programme in December 2009 (Growth Acceleration Act) (Stein and Aricò 2010: 571). Recovery set in by late 2009, and in 2010, GDP grew by $4.1 \%$ and was back to pre-recession levels by early 2011 (Fig. 9.1).

Although Germany was more severely affected by the global economic downturn than most other OECD countries, the unemployment rate rose only modestly

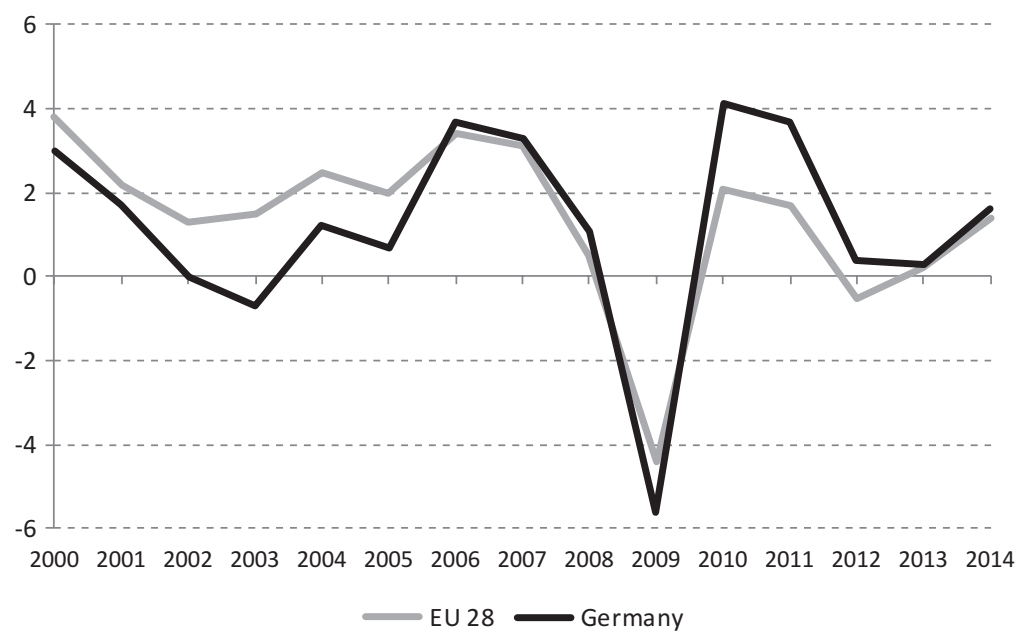

Fig. 9.1 GDP growth rates, EU 28 and Germany, 2000-2014 (Source: http://stats.oecd.org) 


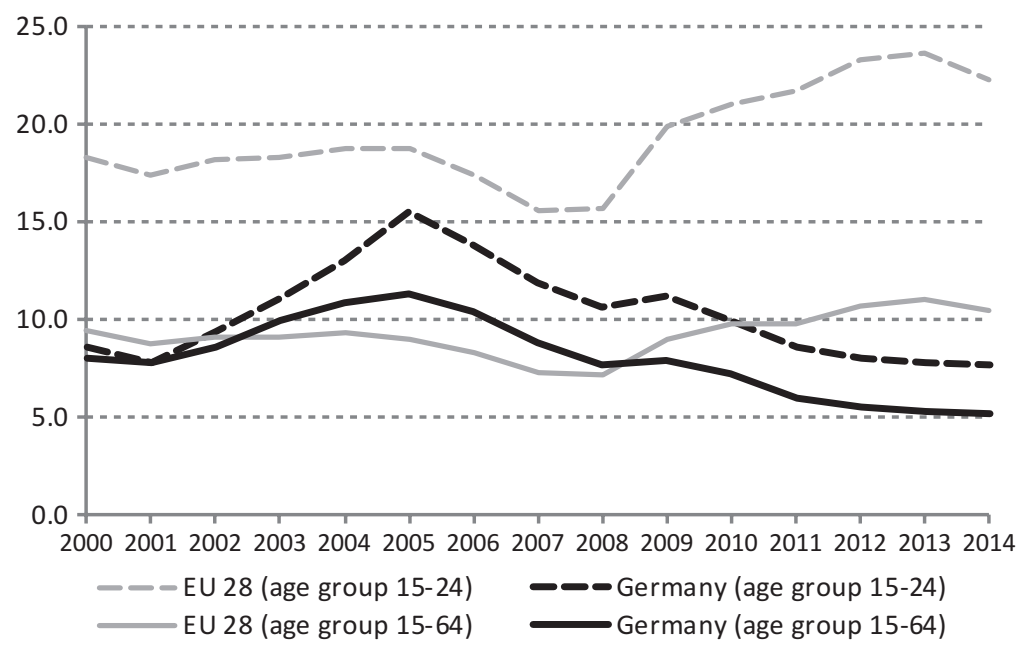

Fig. 9.2 Unemployment rates, EU 28 and Germany, by age groups (15-24 and 15-64), 20002014 (Data for 2000 and 2001: EU 27. Source: Eurostat Database)

between 2008 and 2009. Furthermore, in contrast to the increasing average unemployment within the EU 28, unemployment in Germany has been constantly declining since 2009 (Fig. 9.2).

This successful stabilisation of employment in Germany is related to several factors. Stein and Aricò (2010) note that the crisis primarily affected the manufacturing sector, but the loss of full-time jobs in that sector was compensated by the creation of part-time jobs in the service sector. A set of measures promoting internal flexibility within firms, e.g. the use of working-time accounts and reduction in over time, were a key reason for the stable levels of employment. Most importantly, regulations for short-time work were extended, i.e. companies had more financial incentives to keep their employees during the crisis (workers accepted a reduction in hours and payment, and the state covered up to $70 \%$ of the salary), in order to maintain a skilled labour force after the recession (Stein and Aricò 2010: 571; Hallerberg 2013: 265).

Despite its comparatively good performance, the German labour market has nevertheless taken a problematic turn: job growth is strongly related to an increase in non-standard and precarious employment, a trend which started in the early 1990s. Between 1991 and 2012, the number of part-time workers rose from 2.5 to over 5 million, and the number of employees on fixed-term contracts rose from 2 to 2.7 million workers. Moreover, there were notable increases in the number of temp agency workers and "solo self-employed" (self-employed people who do not have employees). The group of so-called "Minijobbers", i.e. employees working parttime and earning less than 450 Euros per month, grew from 0.65 to 2.55 million (Schulten and Schulze Buschoff 2015: 1-2).

The increase in atypical employment is in part a consequence of changes in the German welfare system - the so-called Hartz reforms. Among other measures, from 
2005, the comparatively generous unemployment compensation, previously calculated as a function of the last wage, was replaced by a needs-tested low-level "flat rate" benefit (Hartz IV) for those still unemployed after 1 year, followed by further cuts if an individual rejected a job offer. These reforms, explicitly seeking to strengthen market forces - assumed to be the best way to create more growth and jobs - resulted in a far-reaching deregulation of the labour market. They did generate more jobs, but led to an increase in precarious employment and growing social insecurity (Bispinck and Schulten 2011: 1).

Nonetheless, the German economic position was comparatively strong, and, together with the lack of jobs in Southern Europe, triggered a sharp increase in intra-EU migration from 2009. Given the precarious situation in their home countries, EU migrants often accept precarious forms of employment and jobs for which they are overqualified. Migrants are overrepresented among the atypically employed (see below).

In recent years, labour force inflow to Germany has also been officially encouraged, primarily as a means to address a skills gap (Fachkräftemangel). Even before the crisis, this shortage of qualified workers and academic specialists had been identified as a potential problem in the near future (Dietz and Walwei 2007). To combat the shortage of skilled workers, the German government decided in 2008 to facilitate labour market access for highly qualified migrants, followed by further comprehensive legal provisions in 2012 and 2013 to attract high-skilled work force from abroad. The December 2014 analysis on labour shortage by the Federal Employment Agency (BA) (BA 2014a) stated that, although there was not a widespread lack of skilled workers, there were shortages in a number of professions. The Whitelist regulating third-country migration into recognised occupations of August 2014 (BA 2014b) includes a limited number of technical specialisations, as well as professions in elderly care, health and nursing. Although detailed future projections are difficult, a recent governmental report highlights the key role of migration and migrant integration for securing employment and growth in Germany (BMAS 2015).

\subsection{Migration Flows: Trends in Immigration to Germany, 2000-2013}

Since 2000, in contrast to earlier periods, immigration to Germany has been characterised by a strong increase in intra-EU immigration. Between 2000 and 2003, the majority of new arrivals still came from non-EU countries. From 2004 on, the annual inflow from EU 26 countries, Norway, Liechtenstein, Iceland and Switzerland (in the following referred to as EU 26+4) always exceeded the number of new arrivals from non-EU member states. The migration statistics data in Table 9.1 show that EU 26+4 flows to Germany more than doubled, largely due to increased migration from Eastern and Southern EU countries to Germany since 2010. Immigration from EU-8 countries increased starting with the 2004 EU enlargement. The absolute 
Table 9.1 Immigration to Germany, 2000-2013: influx per year and net migration balance (in $1000 \mathrm{~s})$

\begin{tabular}{l|r|r|r|r|r|r|r|r|r}
\hline & 2000 & 2002 & 2004 & 2006 & 2008 & 2010 & 2011 & 2012 & 2013 \\
\hline Annual inflow & 70.5 & 56.6 & 43.1 & 39.0 & 43.4 & 57.1 & 82.8 & 117.9 & 141.1 \\
\hline Southern EU & 154.6 & 165.7 & 207.4 & 228.9 & 237.3 & 288.4 & 396.0 & 454.2 & 491.5 \\
\hline Eastern EU & 67.8 & 62.6 & 58.5 & 60.1 & 64.1 & 64.7 & 69.3 & 72.5 & 76.0 \\
\hline $\begin{array}{l}\text { Northern/Western } \\
\text { Europe }\end{array}$ & 293.1 & 285.1 & 309.1 & 328.2 & 345.0 & 410.6 & 548.8 & 645.4 & 709.7 \\
\hline EU 26+4 & 649.2 & 658.3 & 602.2 & 558.5 & 573.8 & 683.5 & 841.7 & 965.9 & 1108.1 \\
\hline Total immigration & 45.1 & 43.3 & 51.3 & 58.8 & 60.1 & 60.1 & 65.2 & 66.8 & 64.0 \\
\hline $\begin{array}{l}\text { \% EU 26+4 on } \\
\text { total immigration }\end{array}$ & & & & & & & & & \\
\hline
\end{tabular}

\section{Net migration balance}

\begin{tabular}{l|r|r|r|r|r|r|r|r|r}
\hline Southern EU & -3.3 & -16.0 & -28.2 & -13.5 & -14.4 & 8.3 & 37.4 & 68.3 & 81.7 \\
\hline Eastern EU & 33.0 & 30.5 & 40.8 & 61.4 & 19.9 & 78.6 & 158.5 & 184.7 & 185.7 \\
\hline $\begin{array}{l}\text { Northern/Western } \\
\text { Europe }\end{array}$ & 11.0 & 6.3 & 0.4 & 13.0 & 3.3 & 9.9 & 18.4 & 21.4 & 22.2 \\
\hline EU 26+4 & 40.8 & 20.9 & 13.0 & 61.0 & 8.8 & 97.0 & 214.7 & 274.9 & 290.4 \\
\hline Total immigration & 86.5 & 152.8 & 55.2 & 74.7 & 10.7 & 153.9 & 302.9 & 387.1 & 459.2
\end{tabular}

Data: Migration Statistics (Destatis 2014)

Southern EU: Greece, Italy, Portugal, Spain; Eastern EU: Bulgaria, Czech Republic, Estonia, Hungary, Latvia, Lithuania, Poland, Romania, Slovenia, Slovakia; Northern/Western Europe: Belgium, Denmark, Finnland, France, Ireland, Iceland, Liechtenstein, Luxemburg, Netherlands, Norway, Austria, Sweden, Switzerland, United Kingdom; EU 26+4: EU 27 countries, Norway, Liechtenstein, Iceland, Switzerland

Migration statistics indicate the number of actual changes of place of residence. Since both arrivals to and departures from Germany are registered, it is possible to calculate annual net migration balances

annual numbers from Southern European countries, which had been decreasing until 2006, slowly recovered from 2007 on, and sharply increased between 2010 and 2013.

In 2013, citizens from EU 26+4 represented $64 \%$ of all new arrivals in Germany. Of the 709,686 EU 26+4 migrants in 2013, 69.3\% came from Central and Eastern European countries and $19.9 \%$ from the Southern European countries. In the same year, 648,911 non-citizens left the country, among them 419,240 people moving to EU 26+4 countries. Balancing arrivals against departures, net migration to Germany was 459,160 in 2013. The highest positive balances were registered for citizens from Eastern EU.

Between 2000 and 2013, the non-citizen population in Germany grew only moderately. While the numbers of Turkish citizens and citizens of the former Yugoslavia declined, data show a clear increase for migrants from Eastern EU countries. Numbers of Southern Europeans increased slightly only from 2011 (Table 9.2). 


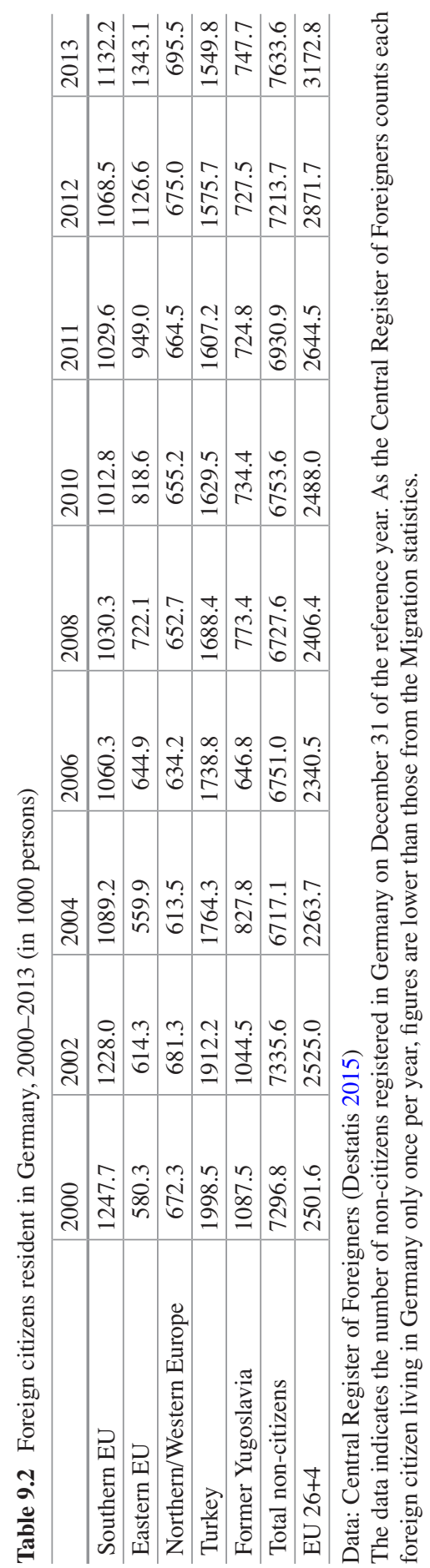


At the end of 2013, 7.6 million non-citizens lived in Germany. Of these, 1.54 million were Turkish citizens, 609,855 held Polish passports, 552,943 were Italians, and the fourth largest group at 316,331 was Greek.

According to 2013 data, first generation immigrants have been living in Germany on average for 22.5 years. The highest averages were recorded for immigrants born in Italy (31.2 years), Turkey (28.7 years) and Greece (28.3 years) (BAMF 2015a: 236). Data show, however, that intra-EU migration in particular no longer necessarily involves the idea of long-term or permanent change of the country of residence. Instead, EU freedom of movement and unrestricted return options seem to have turned migration into a temporary project. $48.9 \%$ of all non-citizens who left Germany in 2013 had stayed for less than 12 months. The share of short-term stays was highest among Romanians (59.4\%) and Spaniards (58.4\%). Among the Italians, Greeks and Portuguese who left Germany in 2013, between $41.9 \%$ and $44.2 \%$ had spent less than 12 months there (BAMF 2015a: 112).

\subsubsection{Demographic Overview: 2012}

In 2012, 15.3 million people, i.e. $19.1 \%$ of the entire population in Germany, had apersonal parental history of migration. ${ }^{1}$ Of those, 10 million were first-generation migrants born abroad, another 5.2 million had at least one parent born abroad, i.e. belonged to the second generation. $42.4 \%$ of the migrants and their children were foreign nationals. Of the working-age population, $20.6 \%$ were first generation migrants or their children. About 1.1 million working-age migrants, i.e. $2 \%$ of the 15-64 years old men and women, arrived between 2007 and 2012.

Migrants living in Germany differ from the native population in terms of age, qualifications, and labour market integration. Overall, migrants are on average younger than the German population. For first generation migrants this is not the case, however, for Aussiedler and for immigrants born in Northern and Western Europe or the former guest worker countries. In terms of labour market perspectives, the age structure among recent migrants has become more favourable: in 2012, migrants' average ages varied from 28.6 (new Turkish migrants) to 34.8 (new migrants from Western and Northern Europe), indicating that in recent years Germany has succeeded in attracting young people.

Levels of formal education are overall higher among native Germans than among migrants. The share of unskilled labourers among Turkish and Southern EU citizens is well above average, due to the fact that many of them are former guest workers who were recruited for low-skilled jobs in the 1960s and 1970s. On the other hand, compared to natives, the share of academics is twice as large among migrants from Western and Northern Europe. Migrants from non-EU countries other than specified in Tables 9.3 and 9.4 have both more unskilled and more highly skilled. Broken

${ }^{1}$ For more details on this concept, see Sect. 9.5. 


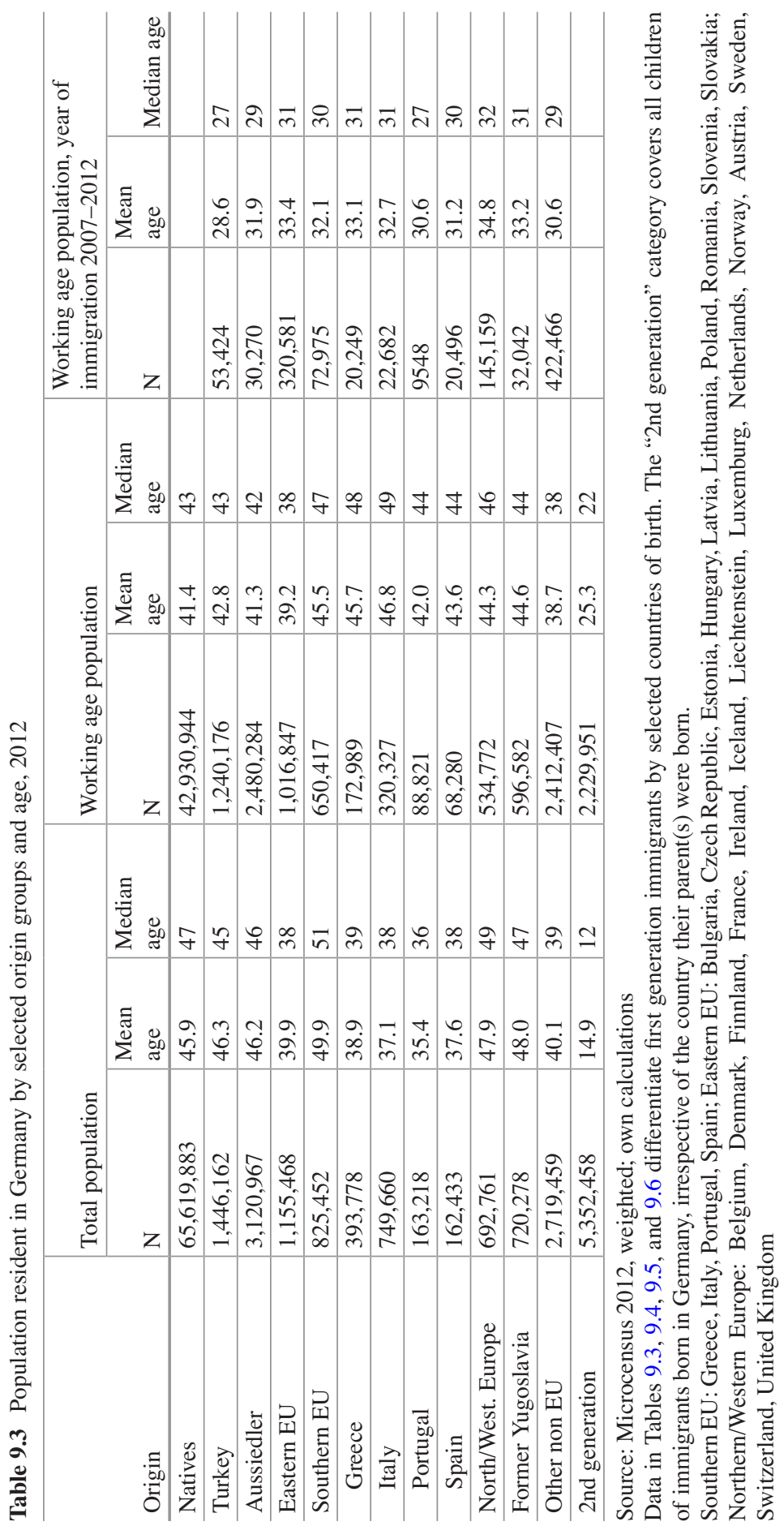


Table 9.4 Working-age population resident in Germany by origin, period of immigration and level of education, 2012 (percentages)

\begin{tabular}{l|l|l|l|l|l|l}
\hline \multirow{2}{*}{ Origin } & \multicolumn{4}{l}{} & \multicolumn{3}{l}{$\begin{array}{l}\text { Recent migrants (year of } \\
\text { immigration 2007 or later) }\end{array}$} \\
\cline { 2 - 8 } & $\begin{array}{l}\text { Total working age population } \\
\text { Low- } \\
\text { skilled }\end{array}$ & $\begin{array}{l}\text { Medium } \\
\text { skilled }\end{array}$ & $\begin{array}{l}\text { High- } \\
\text { skilled }\end{array}$ & $\begin{array}{l}\text { Low- } \\
\text { skilled }\end{array}$ & $\begin{array}{l}\text { Medium } \\
\text { skilled- }\end{array}$ & $\begin{array}{l}\text { High- } \\
\text { skilled }\end{array}$ \\
\hline Natives & 13.53 & 71.05 & 15.42 & & & \\
\hline Turkey & 67.94 & 28.25 & 3.81 & 61.23 & 24.93 & 13.84 \\
\hline Aussiedler & 23.62 & 64.95 & 11.42 & 27.81 & 49.84 & 22.35 \\
\hline Eastern EU & 20.28 & 60.71 & 19.01 & 29.33 & 51.72 & 18.95 \\
\hline Southern EU & 52.89 & 37.02 & 10.09 & 30.83 & 36.53 & 32.63 \\
\hline Greece & 54.23 & 35.64 & 10.13 & 35.23 & 38.18 & 26.59 \\
\hline Italy & 55.91 & 36.06 & 8.03 & 31.52 & 33.67 & 34.80 \\
\hline Portugal & 58.06 & 37.90 & 4.03 & 45.54 & 43.85 & 10.61 \\
\hline Spain & 28.69 & 43.82 & 27.50 & 19.23 & 34.83 & 45.95 \\
\hline North/West. Europe & 15.05 & 50.32 & 34.64 & 12.15 & 44.40 & 43.45 \\
\hline Former Yugoslavia & 41.25 & 52.75 & 6.00 & 31.65 & 52.11 & 16.24 \\
\hline Other non EU & 35.27 & 41.60 & 23.12 & 26.36 & 37.66 & 35.98 \\
\hline 2nd generation & 44.87 & 49.56 & 5.57 & & & \\
\hline Total & 18.30 & 66.66 & 15.05 & 27.45 & 42.92 & 29.63 \\
\hline Sol & & & & & &
\end{tabular}

Source: Microcensus 2012, weighted; own calculations

Low-skilled: primary and lower secondary education (ISCED 0-2), medium-skilled: upper and post-secondary education (ISCED 3-4), high-skilled: tertiary education (ISCED 5-6)

down by field of training, migrants are overall slightly overrepresented in engineering and technical disciplines.

In recent years, Germany has attracted a younger and more highly skilled workforce. Of the migrants who have come to Germany since 2007, $29.6 \%$ are highly skilled. $32.6 \%$ of the recent Southern EU migrants have a university degree. In the latter group, Spaniards have the highest qualifications, regardless of period of migration. These data confirm the results of an analysis of the qualification profiles of EU nationals living in Germany that was carried out by the Expert Council on Integration and Migration. It shows that Germany has profited considerably from the freedom of movement in the EU as a result of the better qualified and younger migrants - on average 10 years younger (SVR 2013: 17-18).

\subsubsection{Labour Market Integration}

Table 9.5 shows that migrants are, relatively, in a weaker position in the German labour market. While Northern and Western Europeans are well-integrated, all other groups, including Southern European migrants, have higher rates of unemployment and of atypical jobs. Despite higher-than-average levels of formal education, recent migrants, especially from non-EU countries, have even greater difficulties in finding 


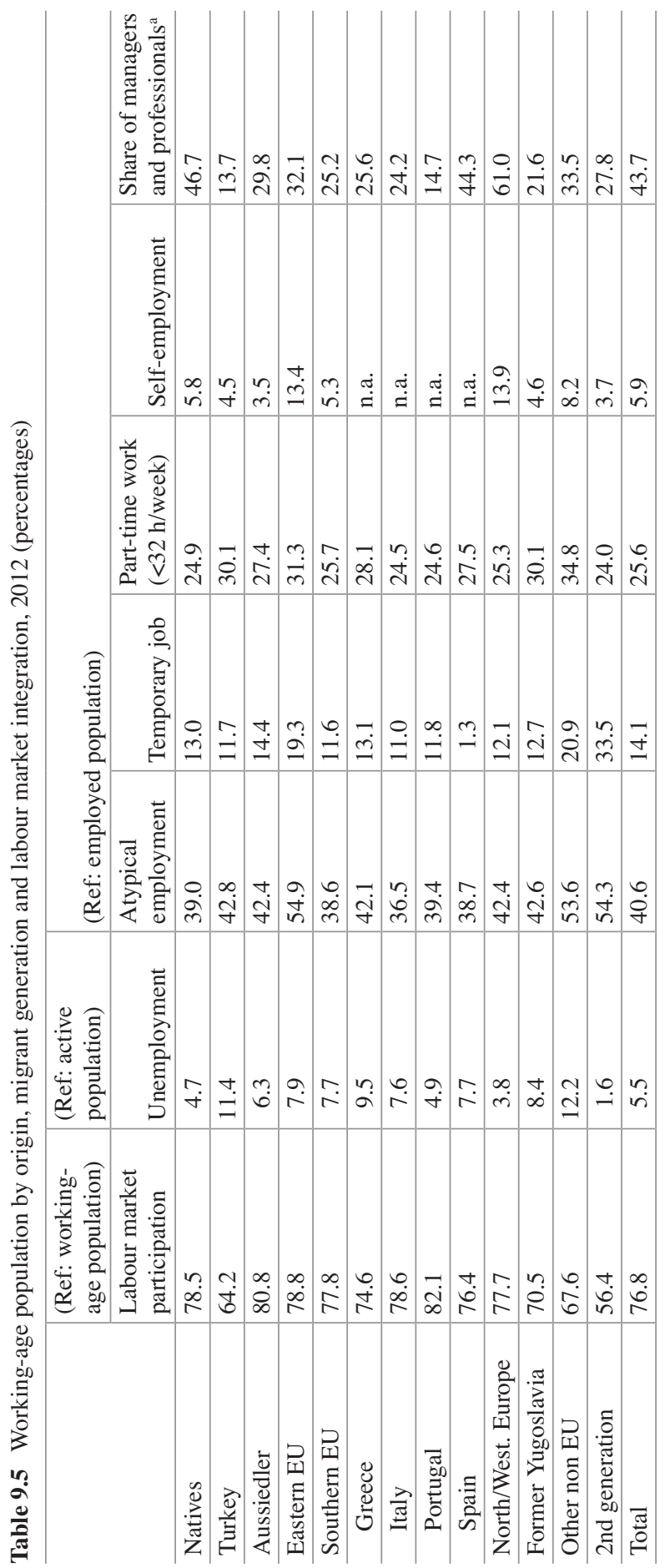




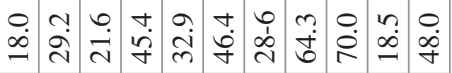

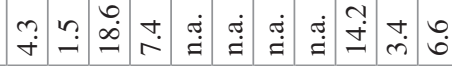

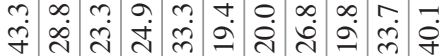

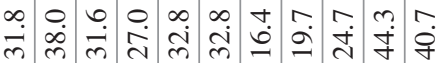

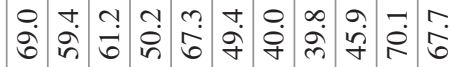

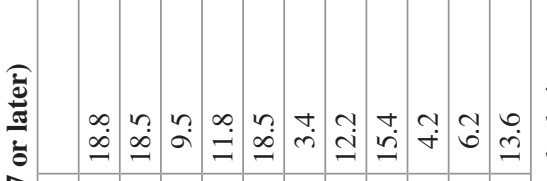

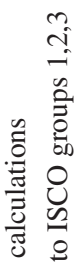

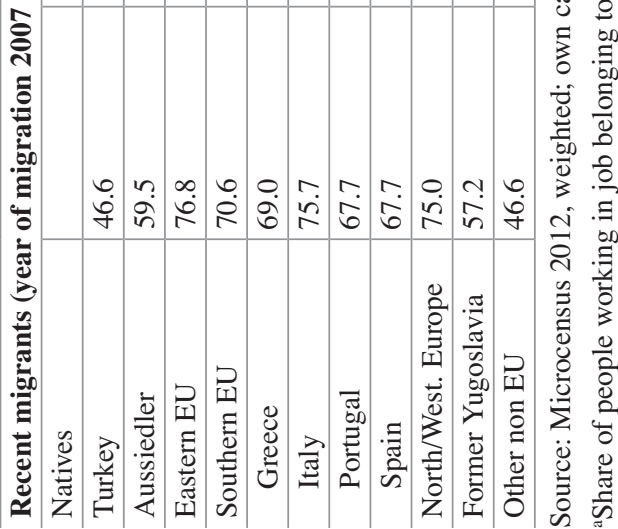


jobs and more often have precarious forms of employment. Recently arrived Italians, however, have lower rates of unemployment than their long-resident compatriots, thus lowering the overall difference between average unemployment and recent migrants' unemployment.

Occupational attainment, ${ }^{2}$ however, is much stronger among recent migrants most notably among the Southern Europeans - which hints at a possible trend towards polarisation in the sense that the highly-skilled are more successful than average, while less qualified newcomers experience more problems than the group average. Labour market outcomes of Western and Northern Europeans are, however, less influenced by length of stay, allowing for the conclusion - strongly supported by the high shares of managers and professionals among them - that it is rather the pull factors that attract migrants who have good labour market perspectives from these countries. On the other hand, a high incidence of non-standard employment, in particular the high rate of temporary jobs, among the other recent migrants highlights the importance of push factors for migration to Germany.

Not reflected in the descriptive data, but uncovered by multivariate analyses, is the fact that migrants often work in jobs for which they are overqualified, in Germany as well as in many other destination countries (Friedberg 2000; Kogan 2003; van Tubergen 2006; Chiswick and Miller 2008). In Germany, disadvantages in occupational attainment are most pronounced for non-EU migrants, but are also substantial for EU-10 and Southern European migrants (Kogan 2011; Fleischmann and Höhne 2013; Höhne and Schulze Buschoff 2015).

Poor prospects in the labour market and precarious forms of employment among migrants are strongly related to risk of poverty and welfare dependency. Data in Table 9.6 show that, due to the relative rates of labour market integration, non-EU migrants have the highest rate of living on minimum social security benefits.

Labour market indicators show that many migrant groups are still unemployed at higher rates and have more precarious employment conditions than German citizens. Lower education levels play a key role, although part of the gap can also be explained by language deficiencies and job-qualification mismatches.

\subsection{Southern European Migration to Post-War Germany: Gastarbeiter Migration in the 1950s, 1960s and 1970s}

Today's Southern European migrants are more highly skilled than the post-war Gastarbeiter or guest workers - so called because they were intended to stay only for several years. This section will discuss key issues relating to this post-war migration flow, with the next section moving on to similar discussions today.

\footnotetext{
${ }^{2}$ Occupational attainment is measured by the share of persons working as managers, professionals or technicians and associate professionals, classified according to the major ISCO groups.
} 
Table 9.6 Predominant source of income of 15 to 64-year olds, by origin, 2012 (row percentages)

\begin{tabular}{|c|c|c|c|c|}
\hline & \multicolumn{4}{|c|}{ Total working age population } \\
\hline & Employment & $\begin{array}{l}\text { Pension, } \\
\text { unemployment } \\
\text { benefits (ALG I), } \\
\text { student education } \\
\text { grants }\end{array}$ & $\begin{array}{l}\text { Family } \\
\text { support, } \\
\text { private } \\
\text { assets }\end{array}$ & $\begin{array}{l}\text { Basic social security } \\
\text { and basic } \\
\text { unemployment benefits } \\
\text { (SGB XII, "Hartz IV") }\end{array}$ \\
\hline Natives & 68.40 & 9.82 & 16.76 & 5.02 \\
\hline Turkey & 49.59 & 10.22 & 24.95 & 15.24 \\
\hline Aussiedler & 68.20 & 8.44 & 15.99 & 7.38 \\
\hline Eastern EU & 65.77 & 6.95 & 19.13 & 8.16 \\
\hline Southern EU & 65.75 & 9.43 & 17.23 & 7.59 \\
\hline Greece & 61.88 & 11.81 & 17.92 & 8.39 \\
\hline Italy & 66.06 & 9.49 & 15.73 & 8.71 \\
\hline Portugal & 72.20 & 6.47 & 16.46 & 4.86 \\
\hline Spain & 65.69 & 6.99 & 23.47 & 3.85 \\
\hline $\begin{array}{l}\text { North/West. } \\
\text { Europe }\end{array}$ & 68.95 & 8.24 & 19.54 & 3.27 \\
\hline $\begin{array}{l}\text { Former } \\
\text { Yugoslavia }\end{array}$ & 57.73 & 14.77 & 17.84 & 9.66 \\
\hline Other non EU & 51.17 & 7.80 & 24.50 & 16.54 \\
\hline 2nd generation & 42.34 & 4.69 & 45.50 & 7.48 \\
\hline \multirow[t]{2}{*}{ Total } & 65.92 & 9.44 & 18.53 & 6.10 \\
\hline & \multicolumn{4}{|c|}{ Recent migrants (year of immigration 2007 or later) } \\
\hline Turkey & 33.33 & 6.68 & 46.74 & 13.25 \\
\hline Aussiedler & 44.22 & 6.24 & 24.33 & 25.21 \\
\hline Eastern EU & 65.52 & 3.99 & 23.74 & 6.76 \\
\hline Southern EU & 59.18 & 5.90 & 30.00 & 4.92 \\
\hline $\begin{array}{l}\text { North/West. } \\
\text { Europe }\end{array}$ & 67.44 & 8.21 & 22.83 & 1.53 \\
\hline $\begin{array}{l}\text { Former } \\
\text { Yugoslavia }\end{array}$ & 46.42 & 15.99 & 31.20 & 6.39 \\
\hline Other non EU & 33.18 & 12.62 & 40.04 & 14.16 \\
\hline
\end{tabular}

Source: Microcensus 2012, weighted; own calculations

Germany became virtually synonymous with Gastarbeiter migration (Castles 1986; Herbert 2003), although, in European comparison, it was a relative late-comer to guest worker recruitment, with Switzerland, Austria and Belgium (see Chap. 7 of this volume) having established such schemes some years earlier. Initially, labour was not needed in Germany, given eight million Germans expelled from former German territories in Eastern Europe (Klekowski von Koppenfels 2002: 116). By the mid-1950s, however, the Wirtschaftswunder (economic miracle) that characterised post-war Germany was well under way, and more workers were needed.

The first of a series of bi-lateral labour recruitment agreements was signed between Italy and Germany in 1955, while the agreement with Turkey, which became 
the most significant, was signed in 1961 (Bpb 2010). In September 1964, Germany celebrated with fanfare the arrival of the one millionth Gastarbeiter (Schulze 2014). Less than ten years later, recruitment was stopped in 1973, following the international oil crisis and worldwide recession. Although migrants and governments alike had expected the guest workers to return "home" in 1973, instead, their families joined them. A number of migrants did return to their home countries, but the overall number of non-German citizens in Germany rose from 3.9 million in 1973 to 4.6 million in 1980, or 7.4\% of the population (Rühl 2009: 49; OECD 1997: 218). In 1985, Turkish citizens were the largest non-German citizen group, at 1.4 million, followed by those from (the former) Yugoslavia at 590,000, Italy and Greece (OECD 1997: 227). Spain and Portugal were the seventh and eighth largest nationalities (OECD 1997: 227). The non-citizen population continued to grow, in part due to continued migration, but also due to a lack of jus soli and low naturalisation among non-Germans: children born to non-German citizens did not automatically become German citizens until 2000 (retroactive to 1990). Germany was heavily criticized until 2000 for its comparatively restrictive - in European comparison - citizenship policy and for its explicit statements that it was not a "country of immigration".

Despite the end of guest worker recruitment in 1973, migration to Germany continued. Family reunification continued to represent a significant number of incoming migrants. 1992 was a high point of net inflow -782,000 (BAMF 2015a: 12) - but exceeded by the 1.1 million net migration in 2015 (Destatis 2016). In addition to family reunification, the net inflow in 1992 also included flows directly linked to the end of the Cold War, with a large number of asylum-seekers $(438,000)$, and migrants who were German citizens - 230,000 Aussiedler, or ethnic German migrants from Eastern Europe and the Soviet Union. Aussiedler migration was restricted sharply starting in 1990 (Klekowski von Koppenfels 2009), and declined to 2400 by 2013 (BVA 2013). This post-Cold War migration flow was a very particular part of the history of migration to Germany.

The primary story of the guest worker migration is the shift from recruitment to family reunification in the 1970s and 1980s, when Germany was a "reluctant land of immigration" (Martin 2014: 224), and to a self-acknowledged country of immigration in 2000. Germany's historical reluctance to embrace migration is the backdrop to the more enthusiastic recruitment of Southern European migrant workers today.

\subsection{Debates in the Twenty-First Century}

\subsubsection{Integration}

The current recruitment of Southern Europeans cannot thus be seen in isolation, but must be examined against the backdrop of the ongoing discussions of about the integration of post-war migrants and their children. When Gastarbeiter recruitment 
ended in 1973, the era of family reunification, and with it the integration of Ausländer, or foreigners, started, albeit in fits and starts - illustrated by an examination of the evolution of the terminology used to refer to non-German citizens living in Germany. A succession of terms has been used and discarded, reflecting the evolving discussion on integration and demonstrating the shift from "reluctant land of immigration" to confirmed immigration country. Over time, the term Gastarbeiter became seen as inaccurate and even offensive, given the clear settlement of migrants in Germany. It was far less common by the early 1980s and was last used in Bundestag documents in 1994.

Government documents and speeches shifted as early as 1976 to the use of the term Ausländer - many of whom were born in Germany. This term gradually became the predominant term, and remained so until the late 1990s. Ausländische Mitbürger, or "foreign fellow citizens" (Boehm 1999), first used by German Chancellor Helmut Kohl in 1987 (Bundesregierung 1987), expressed these individuals' formal non-citizen status, yet captured their social inclusion.

Although ausländische Mitbürger is still used, above all by municipalities, together with Zuwanderer, or migrants, the current predominant term is the unwieldy phrase Menschen mit Migrationshintergrund ("people with a migratory background"; perhaps best translated as "individuals of migrant origin"). It was first used in the 2005 Microcensus, when this group was first defined to include both citizens and non-citizens, referring to any person born outside of Germany after 1949, or born in Germany to at least one parent who was him- or herself born abroad. It thus - significantly - includes both individuals of non-German origin as well as Aussiedler - ethnic German migrants - and their children (Destatis 2013: 6). This term includes all of those who have migrated to Germany, whether German or nonGerman, representing a significant step forward in the inclusion of migrants and their offspring.

Despite Germany's clear shift to seeing itself as an immigration country, there are, as in all immigration countries, still challenges. In 2014 and 2015, there were in Germany, as across Europe, protests against so-called Islamisation, led in Germany by Pegida (Patriotische Europäer gegen die Islamisierung des Abendlandes, or Patriotic Europeans against the Islamisation of the West) (Spiegel Online 2014b; Braden et al. 2015). At nearly every protest, counter-protestors outnumbered the Pegida supporters. Nonetheless, Dresden's high-tech industry was concerned that Pegida protests might deter their much-needed foreign highly skilled workers (El-Sharif and Schultz 2015). Chancellor Merkel clearly condemned the demonstrations in her 2015 New Year address, noting that migration "benefits us all" (Bundesregierung 2014). Germany's status as an immigration country was, once again, clearly acknowledged and supported by the Chancellor. Germany is also the largest receiving country in Europe for Syrian refugees, with clear leadership from Chancellor Merkel, despite some opposition. In addition to over 200,000 asylumseekers who filed a claim in Germany in 2014 (BAMF 2015b) and nearly 500,000 in 2015 (BAMF 2015d), Germany led the EU response to Syrians in 2015, accepting 31,000 of the 120,000 to be re-located within Europe (BMI 2015) and accepting 30,000 Syrian refugees from first countries of asylum; nearly two-thirds of the 
overall European pledge (UNHCR 2015). In short, Germany, like the classic immigration countries United States, Canada and Australia, has clear family, labour and humanitarian streams of migration.

\subsubsection{Country of Immigration}

German politicians famously stated for many years that Germany was "not a country of immigration." A turning point was the Independent Migration Commission's 2001 report which noted that "Germany is, in point of fact, a country of immigration" (Unabhängige Kommission "Zuwanderung" 2001: 1).

This statement reified what had been strongly indicated in 2000 by the passage of a heavily revised Citizenship Act introducing jus soli. Following this Act, children born in Germany to non-citizen parents, at least one of whom had lived for at least 8 years in Germany, received German citizenship at birth. Although naturalisation had long been possible in Germany, and was facilitated in 1990, 1993 and 2000, it often required relinquishing the original citizenship (after 2000 only in about $50 \%$ of the cases), which was shown to be one factor inhibiting naturalisation for non-EU citizens (Böcker and Thränhardt 2006). Taking effect 1 January 2005, a new Immigration Law was another important step in Germany's transition to an immigration country. The Immigration Law effectively introduced highly skilled migration, which became regulated by law, rather than government ordinances such as the Green Card.

There remain significant concerns within Germany about the poorer-thanwished-for integration of Menschen mit Migrationshintergrund, as discussed in Sect. 9.3 above. Their chances of achieving higher education, work commensurate with their education, and employment overall remain lower than those of their native German peers (see Tables 9.5 and 9.6), although numerous policies and programmes are undertaken to address these shortcomings. In 2006, Chancellor Angela Merkel developed a National Integration Plan and introduced the annual Integrationsgipfel, or Integration Summit. Dismissed by some as "nothing more than Kaffeeklatsch" (Conrad 2005), others promoted the event while Chancellor Merkel noted that previously disregarded but important issues had been raised (Conrad 2005).

Recent German government policy vis-à-vis those of migrant origin - recent migrants, long-term residents and their children - is markedly and explicitly more inclusive than at any point in post-war German history. Chancellor Merkel's 2013 statement "It is not enough to be a country with a high migration rate; we also have to become a country of integration" (Die Welt 2013a) is illustrative. Challenges perhaps even the hallmark of an immigration country - remain, such as opposition in some quarters over welcoming nearly 500,000 asylum-seekers in 2015, but they are recognised and steps are taken to address them. 


\subsubsection{Post-Accession Migration}

Post-accession migration from Eastern and Central Europe has been significant (see Table 9.1), despite restrictions placed on EU-8 migration until 1 May 2011. Above all, the migration of Romanian and Bulgarian citizens to Germany, whose freedom of movement restrictions expired on 1 January 2014, raised the question of so-called "welfare migration" or "poverty migration" - the claim that individuals migrated to Germany only to claim benefits. The Institute for Employment Research found that only a minority of Romanian and Bulgarian migrants in Germany were claiming child benefits (16.7\%) (Spiegel Online 2014a), yet widespread impressions of exploitation of the system remained.

Municipalities in Germany were permitted to place restrictions on access to Hartz IV social assistance, a decision contested by a Romanian woman. The case was heard before the European Court of Justice, which decided that EU citizens did not have a right to social assistance during the first 3 months of their stay in another EU country and that countries may deny social assistance to EU citizens who move for the sole purpose of acquiring that assistance (Spiegel Online 2014c; Curia 2014). The deregulation undertaken prior to increased net migration thus continued. The decision does not affect EU citizens who have never worked in Germany nor those who come to Germany to work.

The post-accession migration, coupled with ongoing discussions about integrating the children and grandchildren of the post-war Gastarbeiter and later refugees and other migrants, is another element of the context in which contemporary Southern European migration must be seen.

\subsubsection{Highly Skilled Migration in Germany}

Post-war Gastarbeiter migration was the result of bi-lateral national-level recruitment of low-skilled individuals, needed in the booming post-war economy. The more recent shift toward the recruitment of highly skilled migrants - whether EU citizens or not - can be traced back to concern which emerged in the 1990s over the Fachkräftemangel particularly in the IT industry (Neubecker 2014). Chancellor Gerhard Schröder's unexpected announcement at the 2000 computer fair CeBIT that a programme to cover a labour shortage for IT workers, the so-called Green Card, ${ }^{3}$ would be implemented immediately (Astheimer 2010), was the first policy reflection of this concern. The CeBIT announcement sparked debate, sometimes rancorous, as to whether further immigration to Germany was needed, but the Green Card was implemented (Spiegel Online 2000), just as Germany was shifting to a

\footnotetext{
${ }^{3}$ The programme's name can be assumed to have been intended to invoke the immigration culture of the United States, but it is a misnomer - the Green Card in the United States is the identification of the permanent resident; the H1-B visa would be the equivalent (Kolb 2005).
} 
self-recognition as an immigration country. The concern over lack of skilled workers continues to be reflected today in recruitment from Southern Europe and further.

Nearly 15,000 non-EU nationals (primarily Indians, Russians and Romanians) took advantage of the Green Card programme by mid-2004, a number acclaimed by some, but which prompted others to call it a failure - not all 20,000 annual spots were filled (Kolb 2005, Creutzberg 2013). Above all, however, the programme reintroduced the argument that immigration could be a positive force in Germany (Astheimer 2010) and led to positive debate on the need to reform immigration in Germany (Kolb 2005). Although intended for Third Country Nationals, not EU citizens, and later subsumed into the Immigration Law passed in 2004, the Green Card played a key role in indicating both the willingness of Germany to recruit skilled workers as well as demonstrating the needs of the economy.

\subsubsection{New Recruitment of Southern Europeans in Germany}

Young Southern European engineers, healthcare workers and others, many of whom do not have further training opportunities at home, are explicitly recruited to fill the need for trained labour in a range of professions, thus both providing labour in Germany and gaining skills which could be brought back home. This post-crisis migration could thus be characterised as having elements of migration and development. ${ }^{4}$ Whether they are able to find commensurate employment in their home countries, effectively applying their new training, remains to be seen.

The positive net migration flow from Southern Europe continues, although it is considerably smaller than that of Eastern EU countries (141,000 compared to 491,000; see Table 9.1). This migration flow was widely praised for bringing in skilled workers, but it also led to the discussion of access to social welfare with respect to Southern Europeans; access to basic social assistance - Hartz IV - was restricted first for Greeks, Portuguese and Spaniards before the restriction was extended to EU-10 migrants. As the Federal Labour Ministry said, "We want immigration of skilled workers, not immigration into the social system" (Wisdorff 2012). The large-scale public debate, however, only emerged strongly with respect to EU-10 migrants.

If there is debate about these "model migrants" from Southern Europe (Böcking 2014), then it is that their migration and integration is seen through the lens of the ongoing challenges of integrating the previous waves of migrants (Astheimer 2012). As then-Integration Representative Maria Böhmer said, "We must learn from the mistakes of the past. ... People must feel accepted here. That all belongs to a welcoming culture" (Toprak et al. 2012). Although, overall, the government's tone has been a welcoming one, shortcomings in helping migrants to learn German and settle

\footnotetext{
${ }^{4}$ Migration and development refers to the positive impacts that migration can have upon a sending country, here, migrants returning with additional skills. May also refer to remittances or transfer of knowledge.
} 
in have been acknowledged, and improved mechanisms put in place (Spiegel Online 2014d). In contrast to the post-war flow, it is hoped - by firms and by the government - that these migrants will stay (Kreuzmann and Nienhaus 2013). This double recognition - that these highly skilled Southern European migrants are a positive force for the German economy and society, and that a top-down positive, and long-term, context of reception is crucial for successful integration - is very significant in Germany's still relatively recent position as an immigration country. Even so, recruitment is still not yet at the levels the government aims to achieve.

Recruitment occurs on many levels, ranging from the employers themselves to the Federal Employment Agency. Some rely on their own personal contacts, as one owner of a home health care service with 40 employees does (Siems 2014). Another employer, having difficulty in finding apprentices, spoke with the local chamber of commerce while on vacation in Mallorca, which led to ever-increasing placements of young Spaniards in his construction firm (Bast 2013). Nor is recruitment only from the German side; sending-country middlemen, themselves previously unemployed, have emerged, pairing job-seekers with employment in Germany (Die Welt 2012). Above all, however, recruitment has been coordinated by regions, municipalities, chambers of commerce, professional associations and by the Federal Employment Agency, all of which attend job fairs in Southern Europe. This recruitment serves a real need in Germany, which recognises that demographic change will require more workers, as noted in the government-sponsored "Make it in Germany" webpage (Make it in Germany n.d.).

\subsubsection{Facilitation of Employment}

In recognition of both the current lack of skilled workers and the future demographic need, the German Federal government as well as several EU programmes have considerably facilitated the migration of young Southern Europeans and their recruitment by German firms.

The Federal Recognition Act (Anerkennungsgesetz), taking effect in 2012, sought to simplify the recognition procedure of certain foreign qualifications (OECD 2014: 74). While EU citizens enjoy freedom of movement within the EU, their qualifications often do not travel as freely, with the result that Spanish "doctors may exist as taxi drivers or qualified technicians slave away as laborers" (Siems 2014). The Act sought to facilitate these recognitions (BGBl 2011). The professions affected fell under the federal states' competence; by mid-2014, laws had been put into place in all 16 states (BMBF 2014: 24-25, Anerkennung in Deutschland). The Act was criticised by the Expert Council on Migration and Integration for not including more professions and for not having wholly addressed the complexity of recognition of qualifications (Flohr and Popp 2013), yet prior to the law, it took a doctor's qualifications 13 months, on average, to be recognised, while the Act posits a maximum of three (Peters 2013). The government's initial report on the Act noted, moreover, that "With the Federal Recognition Act, the Federal Government created for the first time a general right to have the equivalence of a foreign qualification 
with a German referential profession assessed" (BMBF 2014: 6). The process of the recognition of qualifications as well as language training is financed by the German Federal Government (OECD 2014: 9).

The Federal Employment Agency, in conjunction with the Federal Ministry of Labour and Social Affairs, has established the programme MobiPro EU, which seeks to attract young EU citizens to Germany. Of applicants in 2013, $60 \%$ were Spaniards (RKW 2013, p. 4). The programme, started in 2013 and scheduled to run through 2018, and its website - Job of My Life ${ }^{5}$ - seeks to promote "vocational mobility of young EU citizens in the European labour market ... to contribute to a reduction in youth unemployment in Europe and to obtain and secure skilled workers in Germany" (BMAS 2014, no pagination). The programme covers German language training in the home country, an introductory internship in Germany and further language training - since increased - among other benefits (BMAS 2014; Böcking 2014). Effort is made, both on the German and migrant side, to achieve success in these migrations. As one migrant said, "We have two apprenticeships" language training and the actual training - (Böcking 2014).

It is unclear how many of the Southern European migrants have been recruited or have spontaneously migrated; exact records are not kept (SVR 2013: 95). The same mechanism which facilitates recruitment by German regions, cities, companies and trade and industry chambers, namely the free movement of workers within the EU, also facilitates spontaneous migration.

\subsubsection{Highly Skilled and Low Skilled Migration Alike}

Although the post-2007 Southern European migrants are, on average, both more highly skilled than their post-war brethren and native Germans (see Table 9.4), those who have primary education do still make up around one-third of the total. For those individuals, also affected by high unemployment in their sending countries, Germany may not represent a more stable situation. As noted above (see Sect. 9.3), the labour market success of recent migrants in Germany is uneven, with skilled migrants achieving well, but the low-skilled considerably less so. Indeed, sociologist Tsianos calls the unstable, low-paid employment in restaurants "a precarious form of EU citizens' labour mobility" (Die Welt 2013b, no pagination).

As noted above (Sect. 9.3), de-skilling plays some role for Southern Europeans (Siems 2014). Indeed, the highly-skilled and others may be working far below their skill level, pursuing additional degrees or working as au pairs, as one Spanish biochemist chose to do, as a "way to learn the language and then look for a job in Germany as a teacher or in a research lab" (FAZ 2012, no pagination). The young man profiled in that 2012 story went on to work at his skill level - as a researcher in the chemical industry - after his current employer read the newspaper story (Petersdorff 2013). At the same time, there is concern, particularly in Italy, over so-

\footnotetext{
${ }^{5}$ https://www.thejobofmylife.de/en/home.html
} 
called brain drain; a higher proportion of the migrants have tertiary education than the general Italian population (Bremer 2013; see also Chap. 4 of this volume).

\subsection{Conclusion}

The new Southern European migration to Germany emerges strongly from Germany's awareness of a need for migrant labour and an acceptance - and embracing - of its status as an immigration country. The backdrop to this migration is the ongoing integration of post-war guest workers and their descendants, increasingly explicitly addressed and facilitated. It can also be seen in the context of what might be called migration and development vis-à-vis Southern Europe. In 2012, Southern European countries became net remittance-receiving countries for the first time in 10 years, indicating that Southern Europeans in Germany and elsewhere are sending money home. Overall, 18 billion US dollars were sent out of Germany worldwide in 2012 (Weingartner 2013).

It is clear that a new era of recruited Southern European migration to Germany is well underway, inevitably inviting comparisons with the post-war Gastarbeiter migration. In 2013, Germany became the most important receiving country within the European Union for internal European migration; one-third of all internal EU migrants went to Germany in 2013 (OECD 2014: 13 and 23). Thanks in part to this migration, in 2013, Germany became the OECD country with the second-largest absolute number of migrants, second only to the United States (OECD 2014: 19). Numerically, as well as philosophically, Germany is a consolidated immigration country.

Nor does the migration from Southern Europe show any signs of slowing down; rather, further recruitment is encouraged by the government. Whether the migration remains a largely circular one or shifts to permanent migration is as yet unclear, although it may be assumed that some portion will remain in Germany. What is also unclear is how the motivating factors of migration (see Chaps. 3, 4, 5, and 6, this volume) and the substantial and increasing labour needs of Germany interact. Above all, from a German perspective, the new Southern European migration is seen in a context of demographic change and foreseeable ongoing labour shortages: "Immigrants are not a threat, but a chance for Germany. Demographic change will promote a rethinking over the next few years" (Borstel 2012).

With its recruitment of highly-skilled workers, today's migration to Germany is remarkably similar to that of classic immigration countries such as the United States, Canada and Australia. As in all immigration countries, debates - at times heated and politically divisive - remain over elements of migration, such as undocumented migration or arrival of asylum seekers, and will continue to do so. In Germany, the debate about "welfare migrants", as opposed to highly skilled young 
Southern Europeans, remains, as does passionate discussion over asylum seekers. Fundamentally, however, it can be said that Germany hopes that migration, particularly from Southern Europe, will continue, and considerable effort and resources have been put into ensuring its continuation.

\section{References}

Anerkennung in Deutschland. (n.d.) Anerkennungsgesetze der Länder. https://www.anerkennungin-deutschland.de/html/de/laendergesetze.php. Accessed 23 Jun 2016.

Astheimer, S. (2010, March 1). Als Einwanderung wieder als Gewinn galt. Frankfurter Allgemeine Zeitung. http://www.faz.net/aktuell/technik-motor/cebit-2010/geburtsstunde-der-greencardals-einwanderung-wieder-als-gewinn-galt-1941918.html. Accessed 13 Feb 2015.

Astheimer, S. (2012, November 18). Arbeitskräfte aus dem Süden: Gut, dass wir die Spanier haben. Frankfurter Allgemeine Zeitung. http://www.faz.net/aktuell/wirtschaft/eurokrise/spanien/arbeitskraefte-aus-dem-sueden-gut-dass-wir-die-spanier-haben-11964675.html. Accessed $13 \mathrm{Feb} 2015$.

BA (Bundesagentur für Arbeit, Federal Employment Agency). (2014a). Der Arbeitsmarkt in Deutschland - Fachkräfteengpassanalyse Dezember 2014. https://statistik.arbeitsagentur.de/ Statischer-Content/Arbeitsmarktberichte/Fachkraeftebedarf-Stellen/Fachkraefte/BA-FKEngpassanalyse-2014-12.pdf. Accessed 12 Feb 2015.

BA (Bundesagentur für Arbeit, Federal Employment Agency). (2014b). Whitelist Immigration into recognised occupations. No. 7, 26.08.2014. http://www.zav.de/positivliste. Accessed 12 Feb 2015.

BAMF (Bundesamt für Migration und Flüchtlinge, Federal Office for Migration and Refugees). (2015a). Migrationsbericht 2013. http://www.bamf.de/SharedDocs/Anlagen/DE/ Publikationen/Migrationsberichte/migrationsbericht-2013.pdf?__blob=publicationFile. Accessed 27 Jan 2015.

BAMF. (2015b, January 14). 202.834 Asylanträge - 128.911 Entscheidungen. http://www.bamf. de/SharedDocs/Meldungen/DE/2015/20150114-asylgeschaeftsstatistik-dezember.html. Accessed 13 Feb 2015.

BAMF. (2015c, August 19). Bis zu 800.000 Asylbewerber erwartet. https://www.bamf.de/ SharedDocs/Meldungen/DE/2015/20150819-BM-zur-Asylprognose.html. Accessed 6 Oct 2015.

BAMF. (2015d, January 6). 476.649 Asylanträge im Jahr 2015. https://www.bamf.de/SharedDocs/ Meldungen/DE/2016/201610106-asylgeschaeftsstatistik-dezember.html. Accessed 10 Mar 2016.

Bast, V. (2013, 17 July). "Sie sind unglaublich motiviert": Wie Bauunternehmer Mezger Azubis in Spanien fand. Impulse: Das Unternehmen Magazin. http://www.impulse.de/management/siesind-unglaublich-motiviert-wie-bauunternehmer-mezger-azubis-in-spanien-fand. Accessed 1 Feb 2015.

BGB1 (Bundesgesetzblatt, Federal Law Gazette). (2011, December 6). Gesetz zur Verbesserung der Feststellung und Anerkennung im Ausland erworbener Berufsqualifikationen (Anerkennungsgesetz). http://www.bmbf.de/pubRD/bqfg.pdf. Accessed 15 Jan 2015.

Bispinck, R., \& Schulten, T. (2011). Trade union responses to precarious employment in Germany (WSI Discussion Paper No. 178). Düsseldorf: WSI.

BMAS (Bundesministerium für Arbeit und Soziales, Federal Ministry for Labour and Social Affairs). (2014, July 24). Promotion guidelines for "Promotion of vocational mobility of young people from Europe interested in vocational training (MobiPro-EU)". https://www.thejobofmylife.de/fileadmin/user_upload/Die_Richtlinien/neu2014_2015/31072014_EN_ Foerderrichtlinie_MobiPro_EU.pdf. Accessed 13 Feb 2015. 
BMAS (Bundesministerium für Arbeit und Soziales, Federal Ministry of Labour and Social Affairs). (Ed.) (2015). Fortschrittsbericht zum Fachkräftekonzept 2014. http://www.bmas.de/ DE/Service/Publikationen/a758-14-fortschrittsbericht-fachkraeftekonzept.html. Accessed 2 Feb 2015.

BMI (Bundesministerium des Innern, Federal Ministry of the Interior). (2015, September 22). EU-Innenminister einigen sich auf Verteilung von 120.000 Flüchtlingen. http://www.bmi. bund.de/SharedDocs/Kurzmeldungen/DE/2015/09/sonderrat-der-eu-innenminister-in-bruessel.html. Accessed 7 Oct 2015.

BMBF (Bundesministerium für Bildung und Forschung, Federal Ministry of Education and Research). (2014). Bericht zum Anerkennungsgesetz. Berlin. http://www.bmbf.de/pub/bericht_anerkennungsgesetz_2014.pdf. Accessed 5 Jan 2015.

Böcker, A., \& Thränhardt, D. (2006). Multiple citizenship and naturalization: An evaluation of German and Dutch policies. Journal of International Migration and Integration, 7(1), 71-94.

Böcking, D. (2014, April 8). "Die Muster-Migranten”. Spiegel Online. http://www.spiegel.de/ wirtschaft/soziales/spanische-zuwanderer-koennten-erfolgsgeschichte-wiederholen-a-962910. html. Accessed 1 Feb 2015.

Boehm, A. (1999, December 29). ad acta (4) Ausländische Mitbürger. Die Zeit No. 1/2000. http:// www.zeit.de/2000/01/ad_acta_4_Auslaendische_Mitbuerger. Accessed 1 Feb 2015.

Borstel, S. (2012, July 4). Her mit den spanischen Fachkräften! Die Welt. http://www.welt.de/ debatte/kommentare/article107755713/Her-mit-den-spanischen-Fachkraeften.html. Accessed 29 Jan 2015.

Bpb (Bundeszentrale für politische Bildung, Federal Agency for Civic Education). (2010, December 20). Erstes "Gastarbeiter-Abkommen" vor 55 Jahren. http://www.bpb.de/politik/ hintergrund-aktuell/68921/erstes-gastarbeiter-abkommen-20-12-2010. Accessed 15 Dec 2014.

Braden, B., Jäschke, M., Otto, F., \& Reinbold, F. (2015, January 13). Pegida-Demo nach Terror in Frankreich: "Schlimm, das in Paris, aber ..." Spiegel Online. http://www.spiegel.de/politik/ deutschland/pegida-die-erste-demo-in-dresden-nach-dem-terror-in-paris-a-1012653.html. Accessed 1 Feb 2015.

Bremer, J. (2013, June 17). Einwanderer aus Italien: Sehnsucht nach deutsche Vita. Frankfurter Allgemeine Zeitung. http://www.faz.net/aktuell/politik/ausland/europa/einwanderer-ausitalien-die-sehnsucht-nach-deutsche-vita-12220525.html. Accessed 1 Feb 2015.

Bundesregierung (Federal Government). (1987, January 2). Neujahrsansprache 1987 von Bundeskanzler Dr. Helmut Kohl. http://www.bundesregierung.de/Content/DE/ Bulletin/1980-1989/1987/01-87_Kohl_.html. Accessed 1 Feb 2015.

Bundesregierung (Federal Government). (2014, December 31). Neujahrsansprache von Bundeskanzlerin Angela Merkel. http://www.bundesregierung.de/Content/DE/ Podcast/2014/2014-12-31 - Video-Podcast/links/download-PDF.pdf? blob=publicationFile \&v=4. Accessed 15 Jan 2015.

BVA (Bundesverwaltungsamt, Federal Office of Administration). (2013). Spätaussiedler und ihre Angehörigen Jahresstatistik 2013. http://www.bva.bund.de/SharedDocs/Downloads/DE/BVA/ Staatsangeh\%C3\%B6rigkeit/Aussiedler/Statistik/J_Jahresstatistik2013.pdf? blob=publicationFile \&v=3. Accessed 10 Jan 2015.

Castles, S. (1986). The guest-worker in western Europe - An obituary. International Migration Review, 20(4), 761-778.

Chiswick, B. R., \& Miller, P. W. (2008). Why is the payoff to schooling smaller for immigrants? Labour Economics, 15(6), 1317-1340.

Conrad, N. (2005, May 28). Integrationsgipfel zu oberflächlich? Deutsche Welle. http://www.dw. de/integrationsgipfel-zu-oberfl\%C3\%A4chlich/a-16839540. Accessed 10 Feb 2015.

Creutzberg, D. (2013, July 30). "Blue Card" Der Ansturm von Hochqualifizierten lässt auf sich warten. Frankfurter Allgemeine Zeitung. http://www.faz.net/aktuell/wirtschaft/wirtschaftspolitik/blue-card-der-ansturm-von-hochqualifizierten-laesst-auf-sich-warten-12312310.html. Accessed 15 Feb 2015. 
Curia. (2014). Case C-333-13. http://curia.europa.eu/juris/documents.jsf?num=C-333/13. Accessed 13 Feb 2015.

Destatis (Federal Statistical Office). (2001-2014). Migration Statistics. Fachserie 1 Reihe 1.2 Bevölkerung und Erwerbstätigkeit. Wanderungen. Wiesbaden: Destatis. https://www.destatis. de/DE/Publikationen/Thematisch/Bevoelkerung/Wanderungen/Wanderungen.html. Accessed 27 Jan 2015.

Destatis (Federal Statistical Office). (2013). Bevölkerung mit Migrationshintergrund Fachserie 1, Reihe 2.2 Bevölkerung und Erwerbstätigkeit. Wiesbaden: Destatis. https://www.destatis.de/ DE/Publikationen/Thematisch/Bevoelkerung/MigrationIntegration/ Migrationshintergrund2010220127004.pdf?_blob=publicationFile. Accessed 26 Jan 2015.

Destatis (Federal Statistical Office). (2015). Central Register of Foreigners. Wiesbaden: Destatis. https://offenedaten.de/dataset/destatis-statistik-12521/resource/5d6510b4-efe2-49f0-a62a5b09819c801e. Accessed 27 Jan 2015.

Destatis (Federal Statistical Office). (2016, March 21). Press Release: Nettozuwanderung von Ausländerinnen und Ausländern im Jahr 2015 bei 1,1 Millionen. Wiesbaden: Destatis. https:// www.destatis.de/DE/PresseService/Presse/Pressemitteilungen/2016/03/PD16_105_12421. html;jsessionid=4AB21217731D387C3FF8C08B02F65565.cae4. Accessed 23 Jun 2016.

Die Welt. (2012, October 31). Junge Griechen suchen ihr Glück in Deutschland. Die Welt. http:// www.welt.de/wirtschaft/article 1 10453704/Junge-Griechen-suchen-ihr-Glueck-inDeutschland.html. Accessed 15 Jan 2015.

Die Welt. (2013a, April 10). Deutschland muss Integrationsland werden. Die Welt. http://www. welt.de/newsticker/dpa_nt/infoline_nt/brennpunkte_nt/article115187409/Deutschland-mussIntegrationsland-werden.html. Accessed 15 Jan 2015.

Die Welt. (2013b, August 2). Viele Griechen arbeiten unter prekären Bedingungen. Die Welt. http://www.welt.de/wirtschaft/article118622419/Viele-Griechen-arbeiten-unter-prekaeren-Bedingungen.html. Accessed 15 Jan 2015.

Dietz, M., \& Walwei, U. (2007). Fachkräftebedarf der Wirtschaft. Wissenschaftliche Befunde und Forschungsperspektiven. Nuremberg: IAB. http://doku.iab.de/grauepap/2007/ Fachkraeftebedarf_Wirtschaft.pdf. Accessed 12 Feb 2015.

El-Sharif, Y., \& Schultz, S. (2015, 16 January). Sorgen um Standort: Pegida-Proteste verunsichern Dresdens Unternehmer. Spiegel Online. http://www.spiegel.de/wirtschaft/soziales/pegidastandort-dresden-gefaehrdet-wirtschaft-besorgt-a-1013117.html. Accessed 2 Feb 2015.

Fleischmann, F., \& Höhne, J. (2013). Gender and migration on the labour market: Additive or interacting disadvantages in Germany? Social Science Research, 42, 1325-1345.

Flohr, M., \& Popp, M. (2013, April 12). Anerkennung ausländischer Abschlüsse: Migrationsrat geißelt “Zuständigkeitsdschungel”. Spiegel Online http://www.spiegel.de/unispiegel/jobundberuf/sachverstaendigenrat-migration-kritisiert-anerkennungsgesetz-a-893870.html. Accessed 1 Feb 2015.

Frankfurter Allgemeine Zeitung (FAZ). (2012, April 29). Krise in Spanien: Vom Biochemiker zum Au-pair: „¡Adiós, España! Frankfurter Allgemeine Zeitung. http://www.faz.net/aktuell/ wirtschaft/eurokrise/krise-in-spanien-vom-biochemiker-zum-au-pair-adios-espa-a-11733969. html. Accessed 15 Jan 2015.

Friedberg, R. M. (2000). You can't take it with you? Immigrant assimilation and the portability of human capital. Journal of Labour Economics, 18(2), 221-252.

Hallerberg, M. (2013). Challenges for the German welfare state before and after the global financial crisis. Cato Journal, 33(2), 263-267.

Herbert, U. (2003). Geschichte der Ausländerpolitik in Deutschland. Bonn: Bundeszentrale für politische Bildung.

Höhne, J., \& Schulze Buschoff, K. (2015). Arbeitsmarktintegration von MigrantInnen in Deutschland. Ein empirischer Überblick nach Herkunftsländern und Generationen. WSI Mitteilungen, 70(5): 345-354.

Klekowski von Koppenfels, A. (2002). The devolution of privilege: The legal background of the migration of ethnic Germans. In D. Rock \& S. Wolff (Eds.), Coming home to Germany? The 
integration of ethnic Germans from Central and Eastern Europe in the Federal Republic (pp. 102-118). Oxford: Berghahn Books.

Klekowski von Koppenfels, A. (2009). From Germans to migrants: Aussiedler migration to Germany. In T. Tsuda (Ed.), Diasporic homecomings: Ethnic return migrants in comparative perspective (pp. 103-132). Palo Alto: Stanford University Press.

Kogan, I. (2003). Ex-Yugoslavs in the Austrian and Swedish labour markets: The significance of the period of migration and the effect of citizenship acquisition. Journal of Ethnic and Migration Studies, 29, 595-622.

Kogan, I. (2011). New immigrants - Old disadvantage patterns? Labour market integration of recent immigrants into Germany. International Migration, 49(1), 91-117.

Kolb, H. (2005, November). The German “Green Card”. focus Migration Policy Brief: 3. Netzwerk Migration in Europa. http://focus-migration.hwwi.de/typo3_upload/groups/3/focus _ Migration_Publikationen/Kurzdossiers/PB03_-_Green_Card.pdf. Accessed 1 Feb 2015.

Kreuzmann, L., \& Nienhaus, L. (2013, June 1). Jugendarbeitslosigkeit in Südeuropa: Traumland Deutschland. Die Welt. http://www.faz.net/aktuell/wirtschaft/eurokrise/jugendarbeitslosigkeitin-suedeuropa-traumland-deutschland-12204514.html. Accessed 15 Jan 2015.

Make it in Germany. (n.d.) "Rekrutierung ausländischer Fachkräfte." http://www.make-it-ingermany.com/de/fuer-unternehmen/potenziale-erschliessen. Accessed 16 Mar 2015.

Martin, P. L. (2014). Germany: Managing migration in the twenty-first century. In J. F. Hollifield, P. L. Martin, \& P. M. Orrenius (Eds.), Controlling immigration: A global perspective (3rd ed., pp. 221-253). Palo Alto: Stanford UP.

Neubecker, N. (2014). Die Debatte über den Fachkräftemangel. DIW Roundup. http://www.diw. de/de/diw_01.c.433615.de/presse/diw_roundup/diw_roundup.html. Accessed $12 \mathrm{Feb} 2015$.

OECD. (1997). Trends in international migration 1997: Continuous reporting system on migration. Paris: OECD.

OECD. (2014). International migration outlook 2014: Special focus - mobilising migrants 'skills for economic success. Paris: OECD.

Peters, F. (2013, April 12). Deutschland, Traumziel für kluge, junge Europäer. Die Welt. http:// www.welt.de/politik/deutschland/article115240481/Deutschland-Traumziel-fuer-kluge-junge-Europaeer.html. Accessed 15 Jan 2015.

Petersdorff, W.v. (2013, May 26). Erfolgreiche Einwanderung: Ein Spanier in Deutschland. Frankfurter Allgemeine Zeitung http://www.faz.net/aktuell/wirtschaft/eurokrise/erfolgreicheeinwanderung-ein-spanier-in-deutschland-12194772.html. Accessed 15 Jan 2015.

RKW Kompetenzzentrum. (2013, November). Beispiele aus der Praxis. Fachkräfte aus dem Ausland: Chancen \& Risiken der Auslandsrekrutierung. http://www.rkw-kompetenzzentrum. de/fileadmin/media/Dokumente/Publikationen/auslandsrekrutierung_12_2013.pdf. Accessed 11 Mar 2015.

Rühl, S. (2009). Grunddaten der Zuwandererbevölkerung in Deutschland (BAMF Working Paper 27). http://www.bamf.de/SharedDocs/Anlagen/DE/Publikationen/WorkingPapers/wp27grunddaten.html. Accessed 1 Feb 2015.

Schulten, T., \& Schulze Buschoff, K. (2015). Sector-level strategies against precarious employment in Germany. Evidence from construction, commercial cleaning, hospitals and temporary agency work (WSI Discussion Paper No. 197). Düsseldorf: WSI.

Schulze, R. (2014, September 10). Ankunft im Wirtschaftswunderland Deutschland. Der Tagesspiegel http://www.tagesspiegel.de/weltspiegel/der-millionste-gastarbeiter-kam-vor-50jahren-ankunft-im-wirtschaftswunderland-deutschland/10677442.html. Accessed 1 Feb 2015.

Siems, D. (2014, January 5). Warum Einwanderer ein Segen für Deutschland sind. Die Welt. http:// www.welt.de/politik/deutschland/article123539929/Warum-Einwanderer-ein-Segen-fuer-Deutschland-sind.html. Accessed 15 Jan 2015.

Spiegel Online. (2000, March 9). Kinder statt Inder: Rüttgers verteidigt verbalen Ausrutscher. Spiegel Online. http://www.spiegel.de/politik/deutschland/kinder-statt-inder-ruettgersverteidigt-verbalen-ausrutscher-a-68369.html. Accessed 15 Jan 2015. 
Spiegel Online. (2014a, December 30). Zuwanderung: Eine Viertelmillion Rumänen und Bulgaren arbeiten in Deutschland. 30 December 2014. Spiegel Online. http://www.spiegel.de/wirtschaft/ soziales/zahl-der-rumaenen-und-bulgaren-mit-jobs-in-deutschland-gestiegen-a-1010772.html. Accessed 15 Jan 2015.

Spiegel Online. (2014b, December 12). Pegida-Aufmärsche: Merkel kritisiert wachsende AntiIslam-Bewegung. Spiegel Online http://www.spiegel.de/politik/deutschland/merkel-undinnenminister-kritisieren-pegida-a-1008100.html. Accessed 15 Jan 2015.

Spiegel Online. (2014c, November 11). EuGH-Urteil: Deutschland muss EU-Ausländern kein Hartz IV Zahlen. Spiegel Online http://www.spiegel.de/wirtschaft/soziales/hartz-iv-eughurteil-zu-frau-aus-rumaenien-in-deutschland-a-1002187.html. Accessed 15 Dec 2014.

Spiegel Online. (2014d, 15 August) Fachkräfte aus der EU: Weise räumt Pannen bei der Integration ein. Spiegel Online. http://www.spiegel.de/wirtschaft/soziales/fachkraefte-aus-der-eu-weise-raeumt-pannen-bei-der-integration-ein-a-986297.html. Accessed 16 Mar 2015.

Stein, U., \& Aricò, F. (2010). Beschäftigungspolitische Krisenreaktionen in Deutschland, Italien und dem Vereinigten Königreich. WSI Mitteilungen, 67(11), 569-576.

SVR (Expert Council on Integration and Migration). (2013). Erfolgsfall Europa? Folgen und Herausforderungen der EU-Freizügigkeit für Deutschland. Berlin: SVR. http://www.svrmigration.de/wp-content/uploads/2013/04/Web_SVR_Jahresgutachten_2013.pdf. Accessed 27 Jan 2015.

Toprak, C., Siems, D., \& Peters, F. (2012, November 15). Südeuropäer fliehen vor der Krise nach Deutschland. Die Welt. http://www.welt.de/politik/deutschland/article111169759/ Suedeuropaeer-fliehen-vor-der-Krise-nach-Deutschland.html. Accessed 15 Jan 2015.

Unabhängige Kommission "Zuwanderung". (2001). Zuwanderung gestalten, Integration fördern: Bericht der Unabhängigen Kommission "Zuwanderung”. http://www.bmi.bund.de/cae/servlet/ contentblob/123148/publicationFile/9076/Zuwanderungsbericht_pdf.pdf. Accessed 15 Jan 2015.

UNHCR. (2015, February). Europe: Resettlement and other forms of admission of Syrian Refugees. http://www.unhcr-northerneurope.org/fileadmin/user_upload/Documents/PDF/ Syrian_Crisis/Map_Europe_Syrian_resettlement_and_other_forms_of_admission_Feb_2015. pdf. Accessed 12 Mar 2015.

Van Tubergen, F. (2006). Occupational status of immigrants in cross-national perspective: A multilevel analysis of seventeen Western societies. In C. A. Parsons \& T. M. Smeeding (Eds.), Immigration and the transformation of Europe (pp. 147-171). Cambridge: Cambridge University Press.

Weingartner, M. (2013, March 22). Migranten in Deutschland: Bargeldströme nach Südeuropa. Frankfurter Allgemeine Zeitung. http://www.faz.net/aktuell/finanzen/fonds-mehr/migrantenin-deutschland-bargeldstroeme-nach-suedeuropa-12122056.html. Accessed 15 Jan 2015.

Wisdorff, F. (2012, March 9). Regierung stoppt Zuwanderung ins Hartz-IV-System. Die Welt. http://www.welt.de/politik/deutschland/article13913511/Regierung-stoppt-Zuwanderung-insHartz-IV-System.html. Accessed 15 Jan 2015.

Open Access This chapter is licensed under the terms of the Creative Commons AttributionNonCommercial 2.5 License (http://creativecommons.org/licenses/by-nc/2.5/), which permits any noncommercial use, sharing, adaptation, distribution and reproduction in any medium or format, as long as you give appropriate credit to the original author(s) and the source, provide a link to the Creative Commons license and indicate if changes were made.

The images or other third party material in this chapter are included in the chapter's Creative Commons license, unless indicated otherwise in a credit line to the material. If material is not included in the chapter's Creative Commons license and your intended use is not permitted by statutory regulation or exceeds the permitted use, you will need to obtain permission directly from the copyright holder.

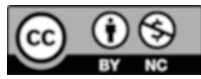




\title{
Chapter 10 \\ UK: Large-Scale European Migration and the Challenge to EU Free Movement
}

\author{
Alessio D'Angelo and Eleonore Kofman
}

\subsection{Introduction}

International migration to the UK in the post-war years had typically concerned post-colonial migrants and then, in the 1990s, asylum seekers: both groups were third country nationals. Although there had been immigration of displaced people from Eastern Europe in the 1940s, and some sizeable flows of Italian workers in the 1950s-1960s, there was no equivalent of the guest worker flows in continental Europe. European immigration grew steadily in the 1980s and 1990s. Nonetheless it only became visible and a major political issue following Eastern enlargement of the EU in 2004 and the UK's opening up without a transitionary period as in most other states. Hostility to immigration has always been present, even when levels were relatively low (Park et al. 2012), but the large-scale post accession migration has once again pushed immigration to the top of the agenda, bolstered by the emergence of a far right party - the UK Independence Party - portrayed as respectable unlike the earlier British National Party.

In this chapter we argue that Eastern European migration has reframed the debate on migration in the UK and led to calls for restrictions on free movement and access to welfare. As Southern European immigration grew, it began to be targeted and used as grounds for restrictions towards EU free movement. We also ask to what extent the recent arrivals from Southern Europe resemble the Eastern European migrants of the early 2000s, who were young and filled labour demand in less skilled occupations, often in areas and regions which had not experienced significant immigration in the last few decades.

In the first section we set out the current socio-economic situation which, though with higher levels of unemployment than during the boom years, has continued to be based on a demand for migrants. We then outline the migratory dynamics and

\footnotetext{
A. D'Angelo $(\bowtie) \bullet$ E. Kofman

Social Policy Research Centre, Middlesex University, London, UK

e-mail: A.Dangelo@mdx.ac.uk
} 
socio-demographic characteristics of Eastern European and, particularly, Southern European flows. In the second part we turn to the debates that have emerged as a result of the changing migratory landscape and the implications this will have for the new and highly educated Southern European migrants who have been increasingly attracted to the UK as the economic crisis hits their own countries.

\subsection{Socio-economic Situation of the Country}

A few months after the start of the recession in 2008, UK unemployment started to rise sharply. When the global financial crisis hit, the unemployment rate was a little over $5 \%$ or 1.6 million. However, in 2009 , it reached $7.5 \%$, to then peak at $8.1 \%$ in 2011. This was the highest level since the early 1990s - but still about 2 percentage points below the European average. The economy has improved since 2012 and the unemployment rate has fallen to $6.4 \%$ for April-June 2014.

Over the same period of time, youth unemployment also reached an historically high level, rising from $15 \%$ in 2008 to $21.3 \%$ in 2011 . Though decreasing as with adult employment, it remains much higher at $16.9 \%$ for the period April-June 2014. As elsewhere, the young have borne the brunt of austerity measures and the increasing use of insecure work contracts. The difficulties in obtaining full-time, stable employment have made it more difficult for them to live independently of their parents, which has been exacerbated by the shortage of affordable housing. In terms of gender differences, female unemployment has historically been lower than for men. This gap was particularly pronounced in 2011 (male unemployment: $8.7 \%$; female unemployment: $7.4 \%$ ); however male unemployment has improved more rapidly (6.6\% in April-June 2014, against 6.2\% among women), in part because of the large scale loss of public sector jobs.

During the 2010-2013 period, the unemployment rate among foreign-born workers - which since the early 1990s had been slightly higher than among UK-born ones (Rienzo 2014)- registered a widening of the gender gap. Whilst the level of unemployment amongst migrant men converged with the natives, the rates among migrant women increased compared to UK-born women.

Although overall unemployment rates have risen and the number of jobs available are less than at the peak of Eastern European immigration almost a decade ago, the economy still relies on migrant labour across a range of sectors and skills. Between January and March 2014, the UK employed 447,000 more UK born and 292,000 non-UK born workers compared to the same quarter of 2013 (ONS 2014). The Migration Advisory Committee (2014) - an independent body to the government - suggests that the demand for migrant workers in the UK is influenced by a broad range of institutions and public policies, such as low level of labour market regulation in some sectors, lack of investment in education and training, low wages and poor conditions in some publicly-funded sector jobs, poor job status and career tracks, and low-waged agency work. Moreover, a large number of zero-hours contracts, that is without fixed hours from week to week, has been created in recent 
years. These give no stability or ability to plan ahead for the worker. The Office for National Statistics recently estimated that employers held 1.4 million contracts with workers that did not guarantee a minimum number of hours. The UK came to be seen as "the self-employment capital of western Europe" (IPPR 2014a). Two-fifths of all new jobs created since 2010 were self-employed; the incomes of these workers have fallen to a much greater extent than of those in regular employment $(14 \%$ compared with 9\%).

Examples of the high use of migrant workers include the construction sector, where increased migrant labour may be the consequence of inadequate vocational training, or the care sector, characterised by low wages, lack of training and rapid turnover (Ruhs and Anderson 2010). At the skilled level, cuts in training places in healthcare arising from reduced budgets for the National Health Service (NHS) have resulted in renewed shortages, as with nurses who have been recruited from Portugal and Spain as well as non-EU countries such as the Philippines (Donnelly and Dominiczak 2014).

\subsection{Migratory Dynamics and Volume of Flows from Southern Europe}

The UK's patterns of immigration have been distinctive compared to other European countries. It had traditionally relied on flows from its former colonies in the Caribbean, South Asia and Ireland, whilst the flows of immigrants from the rest of Europe have been limited and much lower than those experienced, for example, by countries such as Germany, France or Belgium. Migration from Southern Europe, in particular, had been numerically limited in the post-war years, with the exception of a moderately steady inflow of Italian workers during the 1950s and 1960s (D’Angelo 2007; King 1977). These migrants, for the most part coming from Southern Italy, settled in industrial towns such as Peterborough, Nottingham, Coventry, Sheffield and Bedford (attracted by the local brick-making industry).

If the 1970s and 1980s were mainly characterised by a limited number of European migrants, including young people coming to study or for short work experiences as well as highly skilled professionals, from the 1990s intra-European migration became increasingly more significant. Between the 1991 and 2001 censuses, the number of French-born residents increased by $80 \%$, the Spanish by $41 \%$, the Dutch by $35 \%$, and the Italians by $17 \%$. Already in this decade the UK became the preferred destination for Southern Europeans. Morgan (2004: 102), writing about the 1990s, suggested that in relation to the Spanish, this was due to the creation of freedom of mobility, the abolition of work permits, cheap travel, higher educational levels of young Spaniards, buoyancy of the British labour market, comparatively higher levels of unemployment in Spain, and the continuing rise of English as the lingua franca of the business community. More and more professionals, especially in education and health care, came to fill shortages in the labour 
market for which there was active recruitment, especially of nurses. There was a distinct increase in professionals amongst migrants from Southern European countries from $19.4 \%$ in 1992 to $26.6 \%$ in 2000 and a sharp decline in manual workers from $62.5 \%$ to $45 \%$ in the same period. About $43 \%$ of females and $38 \%$ of men had a tertiary degree (Morgan 2004: 140). Another trend had been the increasing proportion of female migrants to over $50 \%$ from a number of European countries.

The accession of ten new countries to the EU in 2004 reshaped European migration patterns. The UK was one of three countries (in addition to Ireland and Sweden) which immediately opened up to the accession states, without imposing any transitory restriction. This was seen as a means of reorienting migratory supply for low skilled labour away from UK's traditional sources such as Bangladesh and Pakistan. Non-EU migrants were restricted to skilled labour markets which would be managed through a Points Based System fully implemented in 2008. As spelled out by the Home Office in its Controlling our Borders paper (2005: 21), "migrants must be as economically active as possible; put as little burden on the state as possible; and be as socially integrated as possible".

Thus between May 2004 and September 2008, 932,000 people from the EU-8 (for the most part Poles) registered initial applications under the 'Worker Registration Scheme' especially set-up by the British government to keep track of new employees from the new EU member states. The total number of those moving to the UK was in fact much higher, given that, for example, self-employed workers were not required to register (Pollard et al. 2008: 9). Still, the WRS figures were well above the original official estimates, which had been for as little as 13,000 per annum. This was in part due to the restrictions imposed by most other European countries, which led to a large-scale immigration to Ireland and the UK. It created the idea that it was impossible to forecast accurately future flows and was used subsequently in heated debates about how many Bulgarians and Romanians would enter after the end of the transition period in 2014 (Migration Observatory 2014).

In the meantime, the number of A8 workers registering had by 2008 sharply declined due to improvements in their economies and decreasing levels of unemployment, declining value of the pound, and the opening up of other EU countries to EU8 migrants as from 2006. It was also estimated that about half the arrivals between 2004 and 2007 had returned home (Pollard et al. 2008). Nonetheless, the entry into the labour market of Bulgarians and Romanians following their accession was restricted since the A8 were seen as already having filled labour shortages whilst raising concerns about the impact they had on public services and wages (see Sect. 10.5 on "Policies and Debates").

As we have noted, the UK has been a preferred destination for Southern European migrants since the 1990s (Gonzalez-Ferrer 2013; McMahon 2012) but for the period 1991-2003 net-migration from other EU countries to the UK was very small. This contrasts with an average annual net-migration from non-EU countries to the UK of over 100,000 migrants for the same period (Migration Observatory 2014). However, the numbers of those entering for work has increased sharply in the 2010s. 
Table 10.1 Population in England and Wales by country of birth

\begin{tabular}{c|l|l|l|l|l|l}
\hline & & & & & & \\
& 2001 (census) & 2011 (census) & $\begin{array}{l}\text { \% change } \\
2001-2011\end{array}$ & 2013 (APS) & CI +/- & 2013 \\
\hline All countries & $52,041,916$ & $56,075,912$ & $7.8 \%$ & $55,595,000$ & $388 \mathrm{k}$ & $-0.9 \%$ \\
\hline UK & $47,406,411$ & $48,570,902$ & $2.5 \%$ & $48,254,000$ & $363 \mathrm{k}$ & $-0.7 \%$ \\
\hline Non UK & $4,635,505$ & $7,505,010$ & $61.9 \%$ & $7,341,000$ & $\ldots$ & $-2.2 \%$ \\
\hline Non EU & $3,953,829$ & $5,469,391$ & $38.3 \%$ & $4,944,000$ & $\ldots$ & $-9.6 \%$ \\
\hline EU* & 681,676 & $2,035,619$ & n.a. & $2,397,000$ & $\ldots$ & $17.8 \%$ \\
\hline A8 & n.a. & $\mathbf{8 8 2 , 7 4 8}$ & n.a. & $\mathbf{9 3 6 , 0 0 0}$ & $\ldots$ & $\mathbf{6 . 0} \%$ \\
\hline Poland & 58,107 & 579,121 & $896.6 \%$ & 581,000 & $39 \mathrm{k}$ & $0.3 \%$ \\
\hline A2 & n.a. & $\mathbf{1 2 5 , 5 8 0}$ & n.a. & $\mathbf{1 7 6 , 0 0 0}$ & $\ldots$ & $\mathbf{4 0 . 1} \%$ \\
\hline Bulgaria & n.a. & 45,893 & n.a. & 49,000 & $11 \mathrm{k}$ & $6.8 \%$ \\
\hline Romania & 7,203 & 79,687 & $1006.3 \%$ & 127,000 & $18 \mathrm{k}$ & $59.4 \%$ \\
\hline South & $\mathbf{2 2 2 , 6 7 4}$ & $\mathbf{3 3 6 , 3 5 3}$ & $\mathbf{5 1 . 1} \%$ & $\mathbf{3 5 5 , 0 0 0}$ & $\ldots$ & $\mathbf{5 . 5} \%$ \\
Europe & & & & & & \\
\hline Greece & 33,224 & 34,389 & $3.5 \%$ & 35,000 & $9 \mathrm{k}$ & $1.8 \%$ \\
\hline Italy & 102,020 & 134,619 & $32.0 \%$ & 134,000 & $19 \mathrm{k}$ & $-0.5 \%$ \\
\hline Portugal & 35,867 & 88,161 & $145.8 \%$ & 103,000 & $17 \mathrm{k}$ & $16.8 \%$ \\
\hline Spain & 51,563 & 79,184 & $53.6 \%$ & 83,000 & $14 \mathrm{k}$ & $4.8 \%$ \\
\hline
\end{tabular}

According to the latest Census, in 2011 there were over 7.5 million foreign-born (i.e. non-UK) residents in the whole of England and Wales. ${ }^{1}$ Of these - as shown in Table 10.1 - about 2 million were EU-born and in particular 135,000 were from Italy, 88,000 from Portugal, 79,000 from Spain and 35,000 from Greece. The total number of Southern European residents $(336,353)$ increased by over $50 \%$ since the previous 2001 Census; however the trend has been very different across different groups. On the one hand, Greek-born residents have gone up by a mere $3.5 \%$ over a decade, whilst over the same period of time Portuguese have increased by $145.8 \%$, Spanish by $53.6 \%$ and Italians by $32 \%$.

Breaking down the Census data by year of arrival confirms the migratory history described above. Of all EU-born people living in England and Wales in 2011, 25.4\% arrived before 1991, 19.2\% in the 1990s and 55.4\% between 2004 and 2011. The proportion of Southern European residents arriving in the latter recent period is significantly smaller - for example $31.6 \%$ among Italians. Unlike other European countries, the UK does not have a system of compulsory registration of residents, thus the best estimate of resident population in a given year - beyond the Census data collected every 10 years - is given by the Annual Population Survey (APS), a yearly dataset combining results from the Labour Force Survey (LFS) with a num-

\footnotetext{
${ }^{1}$ These detailed Census data are available for England and Wales only rather than for the United Kingdom as a whole - i.e. Scotland and Northern Ireland, which together represent over $10 \%$ of the UK population, are not included.
} 
Table 10.2 NiNo registrations - top 20 nationalities (years ending June)

\begin{tabular}{l|l|l|l|l}
\hline & $\begin{array}{l}\text { Year to June } \\
\text { 2010 }\end{array}$ & $\begin{array}{l}\text { Year to June } \\
2013\end{array}$ & $\begin{array}{l}\text { Year to June } \\
2014\end{array}$ & $\begin{array}{l}\text { \% change } \\
2010-2014\end{array}$ \\
\hline Total & 604,347 & 572,876 & 565,719 & $-6.4 \%$ \\
\hline European Union & 284,822 & 398,027 & 420,646 & $47.7 \%$ \\
\hline EU Accession States & 187,328 & 213,893 & 248,852 & $32.8 \%$ \\
\hline $\begin{array}{l}\text { Non European } \\
\text { Union }\end{array}$ & 318,930 & 174,427 & 144,181 & $-54.8 \%$ \\
\hline Top 20 nationalities & \multicolumn{5}{|l}{} & & \\
\hline Poland & 68,721 & 96,481 & 91,561 & $33.2 \%$ \\
\hline Romania & 17,040 & 17,688 & 63,432 & $272.3 \%$ \\
\hline Spain & $\mathbf{1 5 , 0 8 4}$ & $\mathbf{4 7 , 3 2 0}$ & $\mathbf{4 1 , 0 6 5}$ & $\mathbf{1 7 2 . 2 \%}$ \\
\hline Italy & $\mathbf{1 5 , 3 4 1}$ & $\mathbf{3 5 , 8 3 4}$ & $\mathbf{3 8 , 5 3 4}$ & $\mathbf{1 5 1 . 2} \%$ \\
\hline India & 82,156 & 30,781 & 25,916 & $-68.5 \%$ \\
\hline Portugal & $\mathbf{1 0 , 1 7 7}$ & $\mathbf{2 6 , 1 2 6}$ & $\mathbf{2 4 , 1 3 5}$ & $\mathbf{1 3 7 . 2} \%$ \\
\hline Bulgaria & 11,784 & 9,986 & 21,593 & $83.2 \%$ \\
\hline Hungary & 11,923 & 25,215 & 20,233 & $69.7 \%$ \\
\hline France & 17,254 & 21,900 & 20,022 & $16.0 \%$ \\
\hline Rep of Lithuania & 27,377 & 26,611 & 19,341 & $-29.4 \%$ \\
\hline Rep of Ireland & 11,155 & 15,829 & 14,779 & $32.5 \%$ \\
\hline Pakistan & 26,761 & 15,295 & 10,683 & $-60.1 \%$ \\
\hline Slovak Rep & 12,837 & 11,686 & 10,676 & $-16.8 \%$ \\
\hline China Peoples Rep & 12,878 & 11,843 & 10,067 & $-21.8 \%$ \\
\hline Rep of Latvia & 25,868 & 13,257 & 9,594 & $-62.9 \%$ \\
\hline Nigeria & 16,722 & 10,389 & 9,575 & $-42.7 \%$ \\
\hline Germany & 10,966 & 10,978 & 9,448 & $-13.8 \%$ \\
\hline Australia & 13,203 & 11,638 & 9,146 & $-30.7 \%$ \\
\hline Greece & $\mathbf{2 , 4 1 5}$ & $\mathbf{8 , 9 5 7}$ & $\mathbf{8 , 3 0 3}$ & $\mathbf{2 4 3 . 8 \%}$ \\
\hline Czech Rep & 7,901 & 8,435 & 7,909 & $0.1 \%$ \\
\hline Others & 186,784 & 116,627 & 99,707 & $-46.6 \%$ \\
\hline & & &
\end{tabular}

ber of regional 'boosts'. The APS data for 2013 - see Table 10.2 - show a further increase of residents born in Southern Europe, against an overall population which appears almost unchanged. ${ }^{2}$

A good estimate of the most recent flows is offered by the official statistics on National Insurance Number (NINo) registrations. Under the UK system, a NINo registration is generally required by any overseas national looking to work or claim benefits or tax credits. Figure 10.1, which include NINo yearly data between 2012 and 2013, clearly shows a dramatic increase of registration by Spanish, Italian and Portuguese migrants, particularly since 2011, with an annual inflow almost quadrupled over the decade. Overall, NINo registrations from Southern European coun-

\footnotetext{
${ }^{2}$ The confidence interval for the four Southern European populations is between $\pm 9,000$ and $\pm 19,000$; thus the minor changes indicated in Table 10.2 should be read with caution.
} 


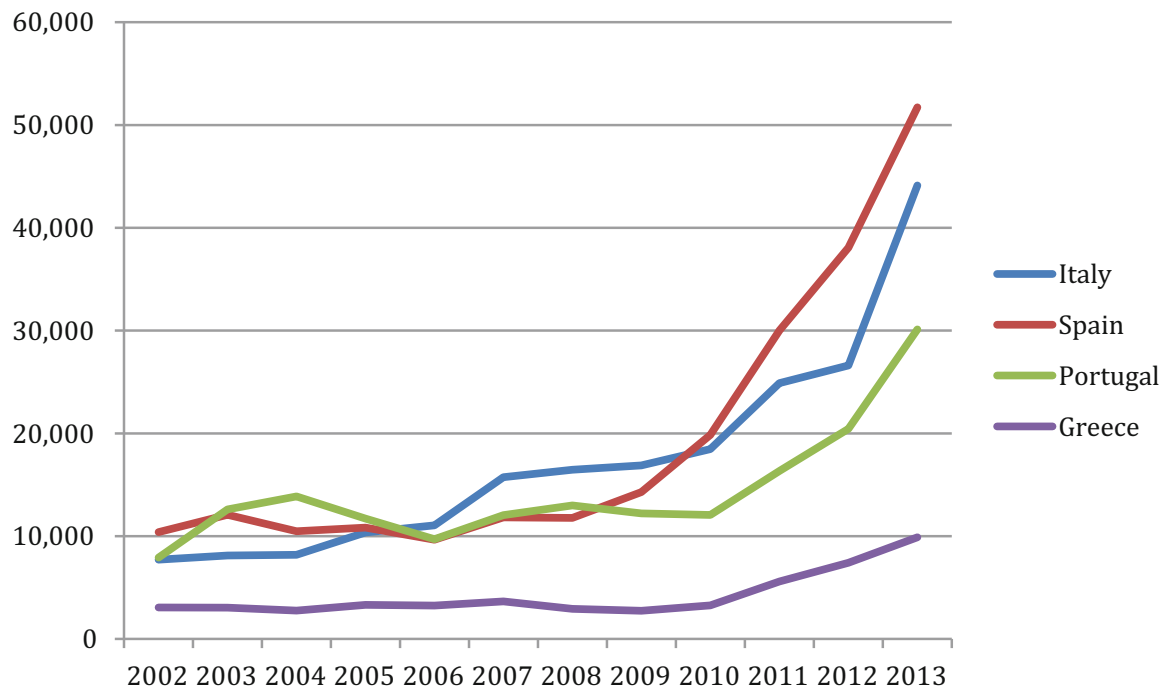

Fig. 10.1 NiNo registrations of Greek, Italian, Portuguese and Spanish nationals (2002-2013) (Source: Authors' data analysis of Department for Work and Pensions data: adult overseas nationals registering for a National Insurance number for the purposes of work, benefits or tax credits)

tries represented about one fifth of all overseas registrations in 2012-2013, compared to less than $10 \%$ between 2002 and 2010 .

As shown in Table 10.2, in the first half of 2014 Spanish, Italian and Portuguese registrations were among the top 6 groups: respectively with 41,000, 38,500 and 24,000 new registrations. ${ }^{3}$ These yearly values are around one and a half times higher than those registered in 2010 (during the same period, the number of yearly registrations from the EU as a whole increased only by $50 \%$, whilst the overall number of overseas registrations has slightly decreased).

\subsubsection{Secondary Migration}

It is difficult to establish the exact degree of secondary migration, which includes two categories: that of citizens of another EU country and third country nationals. The UK has been a popular destination for TCNs gaining citizenship in another country, for example, Somalis from Netherlands and Sweden (Lindley and van Hear

\footnotetext{
${ }^{3}$ A change to the process of recording NINOs during the quarter April to June 2014, means that the volume of NINo registrations recorded is lower in this quarter than would otherwise be the case (estimated to be around 15-25\% lower in the quarter April to June 2014 and 2-5\% lower for the year to June 2014). Hence, comparisons of NINo registrations for the latest periods should be viewed with caution.
} 
2007; van Liempt 2011). Some migrant rights organisations, such as Latin American Women's Rights Services, report an increasing number of Spanish citizens of Latin American origin coming for advice and living in very poor housing conditions. It is also likely that this population may have different socio-economic characteristics than many of the highly educated young Spaniards. Amongst the Portuguese too there are many born in former colonies such as Brazil.

In relation to the mobility of third country nationals, a European Migration Network study (2013) notes that there are limited relevant statistics and lack of comparability. However, existing evidence suggests an increasing trend. In the UK, the long-term migration of non-EU citizens whose country of last residence was the EU, migrating for all reasons, appears to have increased by some $200 \%$, from approximately 1,000 in 2007 to 3,000 in 2011. At the same time it was estimated that longterm migration of EU citizens had declined from 154,000 in 2007 to 147,000 in 2011 (EMN 2012:11). Thus the percentage of third-country mobility in relation to the overall intra-European mobility of both groups has increased from $0.6 \%$ in 2007 to $2 \%$ in 2011. We also know that the number of those applying for work permits from third country nationals residing in another member state rose from 2,940 in 2008 to 3,320 in 2010 but then fell to 2,560 in 2011, the first full year of the Conservative-led coalition government (EMN 2013: 55). Indians constituted the single largest group.

By cross-tabulating 2011 Census data by country of birth and nationality, it appears there are significant numbers of people with Italian, Portuguese and Spanish passports who were born in countries different from their citizenship. In particular, $27 \%$ of UK residents with a Portuguese passport were born in a non-European country (14\% in Africa and 6\% in India), some of whom may have been born in overseas Portuguese territories before de-colonisation. The proportion of nonEuropean born is $15 \%$ for Italian citizens and $12 \%$ for Spanish ones.

It should be noted that the UK has opted out of the major Directives facilitating the mobility of third country nationals such as that regarding third-country nationals who are long-term residents (Directive 2003/109/EC); that on third-country national holders of an EU Blue Card for highly qualified employment in one Member State (Directive 2009/50/EC); those for researchers (Directive 2005/71/EC); and students (Directive 2004/114/EC) (EMN 2013:19).

\subsection{Socio-demographic Characteristics and Labour Market Inclusion}

According to the 2013 Annual Population Survey estimates, UK residents born in Southern Europe appear fairly balanced in terms of gender, with an estimated $48.6 \%$ females among Italians, $49.5 \%$ among Portuguese and $55.4 \%$ among Spaniards. Interestingly, the NINo (2013) data on most recent arrivals suggest a reduction of the female component (see Table 10.3 below) with, for example, only $40 \%$ of women among new entries from Italy. In terms of age, these recent flows - not surprisingly - appear fairly young, with about $80 \%$ of new registered workers from Italy and Spain being aged between 18 and 34 years and only $6 \%$ aged 45 or over. 
Table 10.3 NiNo registrations (2013) by country of birth, age and gender

\begin{tabular}{|c|c|c|c|c|c|c|c|c|c|}
\hline & \multicolumn{3}{|l|}{ Italy } & \multicolumn{3}{|l|}{ Spain } & \multicolumn{3}{|c|}{ Portugal } \\
\hline & \# & Age $\%$ & F\% & \# & Age $\%$ & F\% & \# & Age $\%$ & F\% \\
\hline$<18$ & 354 & $1 \%$ & $46 \%$ & 374 & $1 \%$ & $51 \%$ & 612 & $2 \%$ & $47 \%$ \\
\hline $18-24$ & 18,444 & $42 \%$ & $42 \%$ & 17,503 & $34 \%$ & $51 \%$ & 8,217 & $27 \%$ & $50 \%$ \\
\hline $25-34$ & 17,215 & $39 \%$ & $42 \%$ & 23,546 & $46 \%$ & $47 \%$ & 11,083 & $37 \%$ & $43 \%$ \\
\hline $35-44$ & 5,277 & $12 \%$ & $34 \%$ & 7,243 & $14 \%$ & $41 \%$ & 6,205 & $21 \%$ & $39 \%$ \\
\hline $45-54$ & 2,269 & $5 \%$ & $29 \%$ & 2,544 & $5 \%$ & $39 \%$ & 2,788 & $9 \%$ & $41 \%$ \\
\hline $55-59$ & 343 & $1 \%$ & $31 \%$ & 364 & $1 \%$ & $40 \%$ & 632 & $2 \%$ & $46 \%$ \\
\hline$>60$ & 218 & $0 \%$ & $37 \%$ & 172 & $0 \%$ & $60 \%$ & 593 & $2 \%$ & $51 \%$ \\
\hline Total & 44,120 & $100 \%$ & $41 \%$ & 51,746 & $100 \%$ & $47 \%$ & 30,130 & $100 \%$ & $44 \%$ \\
\hline
\end{tabular}

The picture is however somewhat different for Portuguese migrant workers: with $64 \%$ aged between 18 and 34, $21 \%$ aged 35-44 and $13 \%$ aged over 45 years.

The areas of settlement of Southern European migrants follow the broader pattern of all non-UK and non-EU residents, with about 40-45\% living in the areas of Greater London and about 15\% in the South East of England and the others fairly spread across the rest of the country. The role of London as the main pole of attraction for Southern European migrants appears to have increased in recent years. Among Italians in particular, $68.9 \%$ of those who registered for a NiNo in 2013 were based in London. The data for the same year shows $51 \%$ of Spanish and $44.2 \%$ of Portuguese new arrivals working in the capital.

Detailed information about labour market participation are available from the Labour Force Survey. The data from the second quarter of 2014 shows very different profiles for the four Southern European populations (see Table 10.4 below). Italian-born, with an activity rate comparable with that of the UK-born population, has a much smaller unemployment rate: $3.7 \%$ against $6.0 \%$, whilst for Spanishborn the unemployment rate is exactly the same as among the native population (with a slightly higher activity rate). For those born in Portugal and Greece, however, the registered unemployment rate is around $8.5 \%$ or 2 percentage points above the national average; interestingly, these two groups have also a much smaller proportion of inactive population (about $20 \%$ compared to a national average of $40 \%$ ).

When compared to the latest Census data, these sample-based LFS figures suggest a significant reduction in the unemployment rate among Italian-born residents $(5.2 \%$ in $2011 ; 1.5$ percentage points higher) but very little change among Portuguese-born (8.2\% in 2011). Finally, the Census data by year of arrival reveals much lower unemployment rates among those who have been living in the UK for a long time. Among Italian-born, the rate is just around 3\% for those who first arrived before the 1970s and between 4.5 and 5.5\% for those arriving in the 1970s-1990s.

Similar differences between groups are found when looking at the data by type of occupation (Table 10.5). The proportion of Italians working as managers and senior officials (14.8\%) is significantly higher than the national average (10\%) and the proportion of professionals (31.2\%) is over 10 percentage points above the average. As for Spanish workers, if the proportion of managers ( $8.1 \%)$ is slightly above 
Table 10.4 Population by country of birth and economic activity (LFS 2q2014)

\begin{tabular}{l|l|l|l|l|l}
\hline & In employment & Unemployed & Inactive & Unemployment rate & Activity rate \\
\hline UK & $58.6 \%$ & $3.8 \%$ & $37.6 \%$ & $6.0 \%$ & $62.4 \%$ \\
\hline Non UK & $63.2 \%$ & $5.0 \%$ & $31.9 \%$ & $7.3 \%$ & $68.1 \%$ \\
\hline Greece & $74.7 \%$ & $7.1 \%$ & $18.2 \%$ & $8.6 \%$ & $81.8 \%$ \\
\hline Italy & $62.6 \%$ & $2.4 \%$ & $35.0 \%$ & $3.7 \%$ & $65.0 \%$ \\
\hline Portugal & $73.0 \%$ & $6.8 \%$ & $20.2 \%$ & $8.5 \%$ & $79.8 \%$ \\
\hline Spain & $65.7 \%$ & $4.2 \%$ & $30.1 \%$ & $6.0 \%$ & $69.9 \%$ \\
\hline Total & $59.3 \%$ & $3.9 \%$ & $36.8 \%$ & $6.2 \%$ & $63.2 \%$ \\
\hline
\end{tabular}

Table 10.5 Population by country of birth and occupation (LFS 2q2014)

\begin{tabular}{l|l|l|l|l|l|l|l}
\hline & UK & Non UK & Greece & Italy & Portugal & Spain & Total \\
\hline 1 & $10.2 \%$ & $9.1 \%$ & $1.9 \%$ & $14.8 \%$ & $3.9 \%$ & $8.1 \%$ & $10.0 \%$ \\
\hline 2 & $19.3 \%$ & $22.8 \%$ & $45.8 \%$ & $31.2 \%$ & $22.9 \%$ & $42.2 \%$ & $19.9 \%$ \\
\hline 3 & $14.7 \%$ & $10.4 \%$ & $20.9 \%$ & $10.3 \%$ & $2.9 \%$ & $11.9 \%$ & $14.0 \%$ \\
\hline 4 & $11.2 \%$ & $7.6 \%$ & $11.3 \%$ & $8.4 \%$ & $3.6 \%$ & $6.7 \%$ & $10.7 \%$ \\
\hline 5 & $11.3 \%$ & $9.0 \%$ & $3.9 \%$ & $7.1 \%$ & $9.0 \%$ & $2.2 \%$ & $10.9 \%$ \\
\hline 6 & $9.3 \%$ & $9.7 \%$ & $3.0 \%$ & $4.3 \%$ & $8.2 \%$ & $8.2 \%$ & $9.4 \%$ \\
\hline 7 & $8.1 \%$ & $6.3 \%$ & $6.8 \%$ & $7.2 \%$ & $5.9 \%$ & $6.5 \%$ & $7.8 \%$ \\
\hline 9 & $5.9 \%$ & $8.2 \%$ & $0.0 \%$ & $0.0 \%$ & $11.0 \%$ & $2.1 \%$ & $6.3 \%$ \\
\hline Total & $10.0 \%$ & $16.8 \%$ & $6.4 \%$ & $16.6 \%$ & $32.6 \%$ & $12.2 \%$ & $11.0 \%$ \\
\hline
\end{tabular}

Note: 1 'Managers, Directors And Senior Officials'; 2 'Professional Occupations'; 3 'Associate Professional And Technical Occupations'; 4 'Administrative And Secretarial Occupations'; 5 'Skilled Trades Occupations'; 6 'Caring, Leisure And Other Service Occupations'; 7 'Sales And Customer Service Occupations'; 8 'Process, Plant And Machine Operatives'; 9 'Elementary Occupations'

the average, those working in 'professional occupations' are over $42 \%$ : more than double the national average. At the other end of the spectrum, only $3.9 \%$ of Portuguese-born workers are in the top group, whilst the proportion of those in 'elementary occupations' (32.6\%) is almost three times the national average. Thus the different nationalities exhibit different insertions into the labour market. Italians in particular have a high proportion working in the managerial and professional groups (1-3) together with high levels in low level service employment but negligible in manufacturing, a pattern quite distinct to that of the Portuguese and the Polish.

Furthermore, a comparison with the 2011 Census data suggests an increase of the proportion of Italians working in the top 3 categories of about 5 percentage points. The Census data can also be broken down by year of arrival, revealing that the most recent Italian migrants are those more likely to work as managers or professionals: between 30 and $40 \%$ of those who arrived up to the early 1980s, against over $55 \%$ for those who arrived in the 1990s, 2000s and, again, 2010s. Conversely, the proportion of Portuguese migrants in the top categories is between 20 and $30 \%$ 
for each decade of arrival from the 1960s to date (Detailed 2011 Census data for Spanish migrants is not available).

The distribution by occupational status is partially reflected by the data on the highest qualification of workers (Table 10.6). In particular, among Italian and Spanish-born people, the proportions of those with tertiary education - respectively $62.5 \%$ and $70.7 \%$ - are almost double the UK national average $(35.1 \%)$. On the other hand, Portuguese-born have a lower than average proportion of people with tertiary and secondary education and a proportion of those reportedly with no qualification which is much higher than all other Southern European countries.

Unlike the abundant literature on immigration from the accession countries, and in particular Poland (Ciupijus 2011; Ryan et al. 2008; Sumption and Somerville 2010), there is little published academic research on recent and very recent Southern European flows. Since late 2012, there have been a number of journalistic accounts with titles such as 'PIGS do fly' (PIGS = Portuguese, Italians, Greeks, Spanish) (The Economist 2013) and the 'Return of the Spanish Armada' (The Daily Telegraph 2013). These tend to focus on Southern European migrants working in low skilled jobs in the hospitality, retail and construction sectors, but as the quantitative data presented in this chapter show, many have managed to find jobs commensurate with their education and training. National media has generally represented the young Southern Europeans as forced to flee their countries because of lack of opportunities in a fairly favourable light. In some cases - like in the above mentioned report by the Economist - they are presented as unlikely to remain for long due to their purported strong attachment to family and thus not likely to make claims on public services such as schools for their children. In reality, research evidence on their migration plans and family circumstances is missing (see Chap. 6 by Bermudez and Brey on Spain in this volume where they comment on the gap between Spanish data on emigration and UK data on immigration). It should also be noted that there is a tendency by British journalists (The Economist 2013) to present a somewhat inaccurate history of Spanish migrants, stating that they are predisposed not to migrate except in the early Franco years, thus erasing the earlier European flows of the 1960 s to France, Germany and Switzerland. However, as we shall see in the follow-

Table 10.6 Population by country of birth and qualification (LFS 2q2014)

\begin{tabular}{l|l|l|l|l|l|l|l}
\hline & UK & Non UK & Greece & Italy & Portugal & Spain & Total \\
\hline Tertiary & $33.1 \%$ & $46.1 \%$ & $78.0 \%$ & $62.5 \%$ & $29.3 \%$ & $70.7 \%$ & $35.1 \%$ \\
\hline Secondary & $47.9 \%$ & $23.2 \%$ & $9.5 \%$ & $17.7 \%$ & $29.3 \%$ & $12.1 \%$ & $44.0 \%$ \\
\hline Other & $7.9 \%$ & $19.7 \%$ & $8.0 \%$ & $14.9 \%$ & $29.0 \%$ & $12.7 \%$ & $9.7 \%$ \\
\hline No qualif. & $10.1 \%$ & $10.4 \%$ & $4.4 \%$ & $2.2 \%$ & $12.0 \%$ & $3.9 \%$ & $10.1 \%$ \\
\hline $\begin{array}{l}\text { Did not } \\
\text { know }\end{array}$ & $1.1 \%$ & $0.7 \%$ & $0.0 \%$ & $2.7 \%$ & $0.3 \%$ & $0.7 \%$ & $1.0 \%$ \\
\hline Total & $37,349,283$ & $7,003,680$ & 47,207 & 118,458 & 91,332 & 97,320 & $44,352,963$ \\
\hline
\end{tabular}

Note: Tertiary: degree, higher education or equivalent; Secondary: GCE, A-level, GCSE grades $\mathrm{A}^{*}-\mathrm{C}$ or equivalent 
ing section, the growing hostility towards EU immigration, and more generally the EU, means that the conditionalities being proposed will affect all EU migrants.

\subsection{Policies and Debates}

The debate about immigration and ensuing policies needs to be placed within a very rapid growth of intra European migration although, as we shall see, hostile attitudes were prevalent before this happened. As mentioned earlier in this chapter, estimates of the modest numbers of workers $(13,000)$ arriving in Britain post accession were wildly wrong ${ }^{4}$ (Dustmann et al. 2003) and were spectacularly eclipsed by the arrival of 1.5 million migrants EU8 from 2004 until 2011.

The Conservative-led Coalition government, elected in May 2010, had pledged to bring down net migration to tens of thousands, that is the level of the 1990s. However its only room for manoeuvre was with non-EU migrants, where it has tightened regulations for skilled labour migration and abolished the ability for the highly skilled to enter without a job offer. Less skilled jobs had already been reserved for EU workers under the Points Based System. Students, who count as migrants, have been very hard hit as have family migrants of both UK citizens and permanent residents through the income requirements introduced in July 2012. The Government also could not control the level of emigration, which is part of the net migration figure, except to the extent of not renewing work permits of those already in the country; hence the restrictions placed on moving from temporary to permanent residence permits for skilled migrants and intra-company transferees, which now depend on the level of income.

The national media and many politicians pointed out the fact that EU migration could not be controlled almost as a shocking revelation. By 2012 it was estimated that about 872,000 A8 migrants were resident in the UK. The tabloids took this as the cue for employing their favourite liquid metaphors of floods, deluges, inundations, swamps, and streams, not to mention hordes and invasions, to describe the new arrivals from Eastern Europe (Fox et al. 2012). Subsequently, the ending of the transitionary period for Bulgarian and Romanian migrants generated another moral panic over 'tidal floods of new immigrants'. The Telegraph, a right-wing newspaper, warned that "Britain [is] powerless to stop tens of thousands of Bulgarians and Romanians moving to UK". The Sun, a populist tabloid, talked about "Romanian and Bulgarian immigrants ... threatening to swamp Britain - and flood our overstretched jobs market". A Government e-petition implied that as many as 600,000 people could come, often to seek benefits (cited in Duvell 2013). A number of studies suggesting that potential emigration from these countries was fairly limited were dismissed (Duvell 2013).

\footnotetext{
${ }^{4}$ Dustmann maintains that his estimate was based on the assumption that Germany in particular would open its borders, at least partially (Lowther 2013).
} 
Hostility to immigration is not new and was high even before the large scale immigration from accession countries in 2004. According to the British Social Attitudes Survey (Park et al. 2012), the proportion of respondents favouring some reduction in migration rose from $63 \%$ in 1995 to $72 \%$ in 2003 (with $40 \%$ wishing to see a substantial reduction). The figure increased to $78 \%$ in 2008 , just before the beginning of the economic crisis. Attitudes among the British public had grown increasingly polarised between 2002 and 2011, with those who were educated being more comfortable with immigration compared to those with little education. The polarisation was more evident on views about the economic impact of immigration. Economically and socially insecure groups had become dramatically more hostile although all groups had become at least somewhat more negative about the cultural effects of migration. On the other hand, even for those who were generally negative towards immigration, skilled professional migrants were acceptable.

Although the main target of UK anti-immigration discourse are EU-migrants in general - with those from Poland and, increasingly, Romania and Bulgaria usually identified as the main example - more recently members of UKIP started to make specific reference to Southern European migrants. A party spokesman stated that "What we are seeing is a continued huge influx from eastern Europe now being supplemented by a sharp rise in immigration from southern Europe as citizens from countries like Portugal and Spain find that the only way to escape the eurozone nightmare is to vote with their feet" (BBC 16 November 2014).

\subsubsection{Controversies Around Free Movement of Labour}

The growing anti-immigration sentiments in the mainstream political discourse has always been juxtaposed - when not conflated - with a criticism of the EU system of free-movement and, more generally, with Euro-sceptic stances. The inflated figures and scare stories used by the tabloid papers sustained the growing popularity of far right and anti-immigrant parties and particularly of the United Kingdom Independence Party (UKIP), founded in 1993 by members of the cross-party AntiFederalist League, a political party set up in November 1991. Its aim was to field candidates opposed to the Maastricht Treaty whose main primary objective was the withdrawal of the United Kingdom from the European Union. It is now led by Nigel Farage. Its anti-immigration rhetoric obscures sharply contradictory economic policies from the ultra-liberal favouring further privatisation to more pragmatic positions retaining social institutions, such as the National Health Service (Wigmore 2014). It did well in the 2013 elections but it was in the European election of May 2014, that UKIP received the largest number of votes (27.5\%) and gained 24 representatives. In October 2014 it was the first time in a century that neither the Conservatives nor Labour had won the largest number of votes in a nation-wide election. It gained its first elected Member of Parliament through a by-election for the seat of Clacton, a feat repeated in November 2014 in the constituency of Rochester and Strood. Both by-elections were triggered by the defection of 
Conservative MPs who had joined UKIP. This process has put increasing pressure not only on the Conservative Party, which already encompasses a strong Eurosceptic current, but also on the other political parties.

As from early 2013 David Cameron had promised - in case of a victory in the 2015 elections - a referendum on British membership of the European Union, following a period of renegotiation with the EU. In the meantime, he announced increasing restrictions on welfare rights for EU migrants - stretching current European treaties as far as possible.

The Liberal Democrats, the coalition partner in the previous government and, traditionally, the most pro-European British party, have moved from a proimmigration position to one which supports restrictions on the right to free movement of future entrants as well as restrictions for new entrants coming as self-employed (Mason 2014). Nevertheless the then party leader Nick Clegg reiterated that freedom of movement among EU states was "a good thing" - although it was "never intended as an automatic right to claim benefits" - and was opposed to leaving the EU which would strike an "immense" blow to UK prosperity.

However Clegg also supported Cameron's proposals (The Guardian 29 July 2014) to restrict access to benefits for Jobs Seekers Allowance, child benefits and child tax credits to 3 months instead of 6 months as from November 2014, and that this would only begin after the individual had been in the UK for 3 months. Reports from the BBC suggested that 'at most' 10,000 people would be affected. It would be unlikely to affect EU workers in the UK who lose their job after having made National Insurance contributions and would be limited mainly to those arriving here in the first instance (Grove-White 2014). This measure reflected the attempt by political parties to push the idea that the UK is a welfare magnet, but for which the Migration Advisory Committee (2014) states there is no evidence.

The Labour Party also strove to show how tough it had become and argued that EU migrants should only be able to access welfare payments if they have paid national insurance. The party in government had been accused of allowing uncontrolled immigration through its immediate opening up to migrants from accession countries. As a response to the Conservative's attempt to make immigration a major issue in 2007, Gordon Brown launched the slogan 'British jobs for British workers' at the annual Trades Union Conference (Daily Telegraph 11 September 2007). He had also pledged to make EU migrants learn English which it was estimated would reduce the immigration of the less skilled by about a third.

In 2014, Mark Leonard, Director of the European Council on Foreign Relations, said Labour should push for EU governments to issue social insurance cards to more easily control access to welfare, restrict some benefits for EU migrants for at least a year, and make language tests compulsory for new arrivals. Hence, as UKIP gained ground, Labour sought to toughen its stance, and though not turning its back on free movement, proposed clamping down on tax credits claimed by working EU migrants. The then shadow work and pensions secretary, Rachel Reeves, stated that

${ }^{5}$ Clegg urges restrictions on new EU migrants, BBC 5 August 2014-08-19 http://www.bbc.co.uk/ news/uk-politics-28638493 
the UK social security was not designed for the current level of immigration. ${ }^{6}$ She has thus proposed an increase to 2 years of contributions, which was more than the 3 months announced by the Conservatives. Labour had also raised the possibility of not paying in work tax credits (for low income households) to EU migrant.

It should be remembered that, whilst competence for the coordination of social security schemes is 'shared' between the EU and Member States, Member States have exclusive competence for the design, organisation and funding of their social security systems which differ extensively. Within the overarching EU framework, they are free to decide who is entitled to be insured, which benefits are granted and under what conditions, and how benefits are calculated.

In summer 2014 Cameron (28 July) had also hit out against EURES - the European 'Job Mobility Portal, since of the 2.4 million jobs posted on its web-site, over 1.1 million were in the UK. Jobs at UK firms including supermarket chains Tesco and Sainsbury's are automatically advertised on the site. In future, jobs will only be uploaded to the website if an employer specifically requests that the position is offered across the EU. Thus Cameron stated (28 July 2014) "So we are banning overseas-only recruitment - legally requiring these agencies to advertise in English in the UK ... and massively restricting this, aiming to cut back the vacancies on this portal by over 500,000 jobs" and therefore make easily accessible knowledge about job vacancies in the UK.

In their repeated attempts to outdo each other in terms of firmness on EU migration policies, British political parties are moving the bar further and further. Following his re-election, the former Conservative politician and now UKIP member of Parliament, Mark Reckless, suggested that EU migrants currently living in the UK might be asked to leave the country under certain conditions, should his party be in Government. Although this statement was officially rejected by party leader Farage, it gave an indication of the extent to which every aspect of EU mobility had become the object of political discussions and central to the results of the parliamentary elections of May 2015, as well as the outcome of the referendum on whether the UK should leave the European Union on 23 June 2016.

According to an IPSOS-Mori poll conducted late June/early July 2015 (Nardelli 2015), freedom of movement had become the most contentious issue, and was heavily orienting the vote. The majority of British $(60 \%)$ thought that freedom of movement should be restricted with $70 \%$ of respondents saying that it was due to pressure on public services, $59 \%$ the number coming to the UK to claim benefits, and $55 \%$ pressure on housing. If it were not limited, the proportion who said that the UK should stay in the EU dropped 16 percentage points from $52 \%$ to $36 \%$, while the vote to get out rose by 12 points from $31 \%$ to $43 \%$. Relatively few (16\%) thought that freedom of movement should be kept as it is or with no controls (Nardelli 2015). Amongst the most popular measures to tackle the perceived problems of free movement was the proposal to place restrictions on EU migrants claiming benefits together with broader restrictions to access welfare. These elements were at the centre of the

\footnotetext{
${ }^{6}$ No recourse to public funds applies to non EU migrants who do not have access to a range of non-contributory benefits until they gain permanent residence i.e. minimum of 5 years.
} 
David Cameron's negotiations with the European Commissionfor a 'new settlement for the UK in a reformed EU' ahead of the Brexit referendum. This was not seen as sufficient and in the ensuing referendum $51.9 \%$ voted to leave.

\subsection{Conclusions}

The large-scale immigration of Eastern and more recently Southern Europeans to the UK has progressively fed increased hostility towards immigrants and contributed to the popularity of curbs on free movements and access to welfare. The filling of low skilled labour from these countries has contributed in particular to such calls. However the analysis of quantitative data seems to show that the Italians and Spanish in particular are not filling the less skilled sectors in the same way as Polish migrants have done. They are geographically more concentrated in the large urban centres which have long experience of immigration, both of labour migrants and asylum seekers and refugees. Even within the lower level service sector, they are often working in the hospitality sector and are less likely to be seen as being in competition with less educated local populations.

As has been commented, the current immigration debate demonstrates the loss of statistical reasoning. Following a period of large scale immigration from Eastern Europe, conflict over competition in employment, pressure on public services and access to welfare have been the issues which have led to increased hostility towards immigration aired in the media and increasingly taken up by political parties across the spectrum apart from the Greens and the Scottish Nationalist Party. According to IPSOS-Mori (2014) immigration has become the single most important issue of concern to the British public and ended up becoming the major issue in the vote to leave the European Union, even in areas with low levels of immigration. The results of the referendum, which saw a high turnout, revealed profound polarisation, with those with lower educational qualifications, older people and those living in provincial England, more likely to vote in favour of leave. Outside of London, Scotland and Northern Ireland were the only two areas to vote in favour of remaining in the EU (Ford 2016). The Brexit vote opens up a period of economic and political insecurity and constitutional instability with unpredictable outcomes for the status of EU migrants currently in the UK and for the future of intra-European migration.

\section{References}

(2014) Spanish workers flock to Britain in record numbers, the Local http://www.thelocal. es/20140228/spanish-workers-flock-to-britain-in-record-numbers (English language version of Spanish newspaper).

Barbulescu, R. (2014) EU freedom of movement is coming under increasing pressure in the UK and other European states. blogs.lse.ac.uk/europpblog/2014/02/20/eu-freedom-of-movementis-coming-under-increasing-pressure-in-the-uk-and-other-european-states/ Accessed $20 \mathrm{Sept}$ 2014. 
Bristol Post. (2013). http://www.bristolpost.co.uk/VE-SWAPPED-SPANISH-SUN-SOUTHVILLE /story-20109545-detail/story.html, 21 November. Accessed 10 Dec 2014.

Cameron, D. (2014, 28 July). We're building an immigration system that puts Britain first. Daily Telegraph.

Ciupijus, Z. (2011). Mobile central eastern Europeans in Britain: Successful European citizens and disadvantaged labour migrants. Work, Employment and Society, 25(3), 540-550.

D’Angelo, A. (2007). Britalians. Le migrazioni italiane in Gran Bretagna, in Rapporto Italiani nel Mondo. Rome: Fondazione Migrantes, Idos.

Donnelly, L., \& Dominiczak, P. (2014, May 13). Number of foreign nurses up 50pc in a year. More than 5,000 nurses come to UK from EU, as NHS cuts training for home-grown staff. Daily Telegraph.

Dustmann, C., Casanova, M., Fertig, M., Preston, I., \& Schmidt, C. (2003.) The impact of EU enlargement on migration flows. Home Office on Line Report 25/3.

Duvell, F. (2013). Romanian and Bulgarian migration to Britain: Facts behind the fear. Our Kingdom: Power and liberty in Britain, 28 March https://www.compas.ox.ac.uk/news/latest/ article/date/2013/04/duevell-on-the-facts-of-romanian-and-bulgarian-migration-to-the-uk/ Accessed 10 Dec 2014

EC. (2012, June). EU employment and social situation. Quarterly Review.

Economist, The. (2013). 'PIGS' can fly. Economist 16 Nov http://www.economist.com/news/ britain/21589879-some-european-economic-migrants-are-more-welcome-others-pigs-can-fly. Accessed 20 Sept 2014.

EU migrant curbs should be 'temporary' says Major. BBC http://www.bbc.co.uk/news/ukpolitics-30073844 16 November 2014 Accessed 10 Dec 2014.

European Migration Network. (2013). Intra-European mobility of third-country nationals, synthesis report.

Ford, R. (2016, June 26). The 'left-behind', white, older, socially conservative voters turned against a political class with values opposed to theirs on identity, EU and immigration. The Observer.

Ford, R., Morrell, G., \& Heath, A. (2012). Fewer but better? Public views about immigration (British Social Attitudes, Vol. 29). London: NatCen Social Research.

Fox, J., Moroșanu, L. E., \& Szilassy, E. (2012). The racialization of the new European migration to the UK. Sociology, 46(4), 680-695.

González-Ferrer, A. (2013). La nueva emigración española. Lo que sabemos y lo que no. Madrid: Fundación Alternativas (Zoom Político, issue 18).

Grove-White, R. (2014, July 30). What will Cameron's immigration crackdown mean for migrants?, Migration Rights Network.

Her Majesty's Government. (2014). Review of the balance of competences between the United Kingdom and the European Union single market: Free movement of persons

Institute for Public Policy Research. (2014a). UK becoming the 'self-employment capital' of Western Europe, London. Available from: http://www.ippr.org/news-and-media/press-releases/ uk-becoming-the-\%E2\% 80\%98self-employment-capital\%E2\% 80\%99-of-western-europe. Accessed 15 Jan 2015.

Ipsos MORI. (2014). Ipsos MORI Issues Index - October 2014. Available from: https://www. ipsos-mori.com/researchpublications/researcharchive/3468/EconomistIpsos-MORI-October2014-Issues-Index.aspx. Accessed 1 Feb 2015.

King, R. (1977). Italian migration to Great Britain. Geography, 6(3), 176-186.

Lindley, A., \& van Hear, N. (2007). New Europeans on the move: A preliminary review of the onward migration of refugees within the European Union (COMPAS Working Paper 57), University of Oxford.

Lowther, E. (2013). Prof says his ' 13000 EU migrants' report 'misinterpreted' BBC 7 March. http://www.bbc.co.uk/news/uk-politics-21682810. Accessed 1 Feb 2015

Mason, R. (2014, August 4). Clegg to call for tighter EU immigration rules. The Guardian, 6. Accessed 1 Feb 2015. 
McMahon, S. (2012). Gli accademici italiani nelle università britanniche, in Rapporto Italiani nel Mondo 2012. Rome: Fondazione Migrantes, IDOS.

Migration Advisory Committee. (2014). Migrants in low-skilled work: The growth of EU and nonEU labour in low-skilled jobs and its impact on the UK. London.

Migration Observatory. (2014). Migrants in the UK labour market: An overview. Oxford: University of Oxford.

Morgan, T. (2004). The Spanish migrant community in the United Kingdom. Cambridge: Anglia Ruskin Polytechnic University.

Nardelli, A. (2015, October 9). EU referendum: Polling reveals freedom of movement most contentious issue. The Guardian. http://www.theguardian.com/news/datablog/2015/oct/09/eureferendum-polling-reveals-freedom-of-movement-most-contentious-issue. Accessed 9 Oct 2015.

Office of National Statistics. (2014, June). Labour market statistics.

Park, A., Clery, E., Curtice, J., Phillips, M., \& Utting, D. (Eds.). (2012). British social attitudes: The 29th report. London: NatCen Social Research. Available online at: www.bsa-29.natcen. ac.uk Accessed 1 Feb 2015.

Pollard, N., Latorre, M., \& Sriskandarajah, D. (2008). Floodgates or turnstiles? Post-EU enlargement migration flows to and from the UK. London: Institute for Public Policy Research.

Rienzo, C. (2014). Characteristics and outcomes of migrants in the UK labour market. Oxford: The Migration Observatory.

Ryan, L., Sales, R., Tilki, M., \& Siara, B. (2008). Social networks, social support and social capital: The experiences of recent Polish migrants in London. Sociology, 42(4), 672-690.

Sumption, M., \& Somerville, W. (2010). The UK's new Europeans: Problems and challenges five years after accession. London: Equality and Human Rights Commission.

Van Liempt, I. (2011). And then one day they all moved to Leicester: The relocation of Somalis rom the Netherlands to the UK explained. Population, Space and Place, 17, 254-266.

Wigmore, T. (2014, November 19). Is UKIP the most divided party in British politics? A fundamental economic tension runs through UKIP. New Stateman.

Open Access This chapter is licensed under the terms of the Creative Commons AttributionNonCommercial 2.5 License (http://creativecommons.org/licenses/by-nc/2.5/), which permits any noncommercial use, sharing, adaptation, distribution and reproduction in any medium or format, as long as you give appropriate credit to the original author(s) and the source, provide a link to the Creative Commons license and indicate if changes were made.

The images or other third party material in this chapter are included in the chapter's Creative Commons license, unless indicated otherwise in a credit line to the material. If material is not included in the chapter's Creative Commons license and your intended use is not permitted by statutory regulation or exceeds the permitted use, you will need to obtain permission directly from the copyright holder.

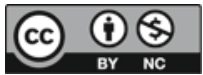




\title{
Chapter 11 \\ South-North Labour Migration Within the Crisis-Affected European Union: New Patterns, New Contexts and New Challenges
}

\author{
Jean-Michel Lafleur, Mikolaj Stanek, and Alberto Veira
}

\subsection{Introduction}

For centuries, migration has been a widely spread response to both adversity and economic opportunities in Europe. In spite of variations in the size and characteristics of migration flows, Europeans have historically moved from less prosperous regions to more prosperous ones. Expanding economies, hungry labour markets, higher salaries and also political instability are just a few of the factors that have triggered European migration over the years.

Nowadays, a revival of past South-North migratory routes seems to be taking place as a consequence of the ongoing economic crisis. However, three distinctive features need to be immediately underlined. First, before the economic crisis, Southern European countries had become net receiving countries during the first 8 years of the twenty-first century. This involved these Member States having to think of themselves again as countries of emigration. As we have seen in different chapters of this volume, the very acknowledgement of the existence of crisis-related migration is often a controversial topic. Second, the degradation of Southern European economies has reduced migration to this area from third countries and Central and Eastern European Member States. Third, contrarily to twentieth century South-North European migration, Southern European migrants are now leaving

\footnotetext{
J.-M. Lafleur ( $\square)$

FRS-FRNS, Centre for Ethnic and Migration Studies (CEDEM), University of Liège,

Liège, Belgium

e-mail: jm.lafleur@ulg.ac.be

M. Stanek

Department of Sociology and Communication, University of Salamanca, Salamanca, Spain e-mail:mstanek@usal.es
}

\author{
A. Veira \\ Department of Social Analysis, Carlos III University of Madrid, Madrid, Spain \\ e-mail: aveira@polsoc.uc3m.es
}


countries hard hit by the crisis and moving to countries that have also been affected by the economic downturn (although in a significantly lesser extent). In Northern European Member States, demand for foreign labour and growing anti-immigrant sentiments have created an unwelcoming context for further migration following the crisis. For this reason, post-crisis migration from Southern Europe constitutes a very novel and challenging research topic.

One of the objectives of this volume was to describe the scale, intensity and fundamental social and demographic features of this new Southern European mobility and to identify the main patterns of the socio-economic integration of Southern EU migrants into Northern European destination countries. Throughout this book, this objective was pursued through the analysis of the most recent available statistical data on flows, stocks and profiles of this new migrant category using data sources from both sending and receiving countries. While the national chapters explored the main traits and particularities of new South-North intra-European migration from the specific perspective of sending and receiving countries, the purpose of this chapter is to identify and discuss the main features of this new phenomenon on a more general level.

The statistical data in the country-specific chapters shows that there are at least two distinctive features that characterize current South to North migration. Firstly, its intensity is relatively low if we take into account, on the one hand, the scale of the crisis-driven deterioration of the labour markets in southern countries and, on the other, the volume of the previous South-North migration in the post-war period. Secondly, as shown in previous chapters, new Southern European migrants are predominantly young and highly educated, particularly when compared with their counterparts, who migrated during the 1950s, 1960s and 1970s.

What factors are behind these particularities of the current South-North migration flows? In this chapter, we argue that, while the asymmetric impact of the economic crisis throughout the European Union and the unique features of the deeply fragmented labour markets of its Southern member countries may be considered primordial factors that triggered a renewed South-North intra-European mobility, the intensity and composition of these flaws are also determined by the previous structural, demographic, social and economic transformation experienced by both Southern and Northern EU countries. We start this chapter with a brief description of the unequal effects of the economic crisis in the European Union. We then discuss the recent history of migratory flows in Europe and describe how the recent economic crisis has affected intra-EU migratory flows. In the sections that follow, we explore the features that make current migratory trends significantly different from the post-war South-North migratory waves. We also discuss the apparent contrasts between the harshness of the economic crisis experienced by the southern periphery of the EU and the relatively low intensity of mobility when compared to the previous post-war South-North migrations. Finally, we shed some light on factors underlying the fact that migration has become a strategy adopted mainly (although not exclusively) by young and relatively well-educated Southern Europeans. 


\subsection{The Economic Crisis in EU Countries: An Overview}

As shown throughout this volume, the consequences of the economic crisis have been particularly devastating for Southern EU members, and have had a significant impact on the increase in South-North mobility. The linkages between the state of the European economies and migration have emerged as one of the most important topics in recent scientific debates on migration (Canetta et al. 2014; Castles and Vezzoli 2009; Kahanec et al. 2014). A growing number of publications have assessed the dynamics of the crisis and its impacts on the mobility patterns of EU nationals as well as of third country nationals (see Kahanec and Kurekova 2014; OECD 2011, 2012; Kaczmarczyk and Stanek 2015). What needs to be emphasized is that although in its initial phase, the economic deterioration spread throughout most of the developed countries, its consequences are not equally distributed among Member States (Kahanec and Zimmermann 2014). As can be seen in Table 11.1, the significant economic growth experienced in most of the EU since the turn of the present century ended abruptly during the years 2008 and 2009. The table also shows that taking as a whole the net growth for the period 2008-2013, important differences can be observed. Whereas Southern and Baltic EU countries, as well as Ireland, suffered from a major recession, other countries such as Germany and Slovakia saw a short-duration economic decline followed by a period of dynamic recovery. Poland is the only country in the EU that did not experience any negative growth (although its economy did also slow markedly).

The asymmetric impact of the crisis has also been reflected in disparities in austerity-driven economic policies implemented across the EU. The drop in economic growth, together with monetary imbalances resulting from the financial crunch of 2007, has affected strongly the fiscal sustainability of national economies. The extraordinary growth of public debt and the pressure exerted by EU and international financial institutions for urgent fiscal consolidation pushed hard-hit Southern European countries to reduce radically their public spending. Crucial spheres of the Welfare State such as health care and education were particularly affected by these measures. Although several crisis-affected Northern EU Member States also implemented austerity measures in order to safeguard financial stability (i.e. mainly through tax increases and cuts in public spending), their range and social impacts were less drastic when compared to those of Southern Europe (Karger 2014; Matsaganis and Leventi 2014).

The uneven impact of the economic crisis is also reflected in unemployment data. As shown in Table 11.2, while unemployment rates have remained stable or increased moderately in Northern Europe, Southern European Member States have suffered dramatic increases. Although the economic crisis has affected cyclically sensitive sectors such as construction, services and some branches of manufacturing, Northern EU countries have generally been more successful in tackling the unemployment crisis whether through ad hoc employment policies (see Chap. 7 of this volume) or by relaxing labour market regulations (see Chap. 10 of this volume). 
Table 11.1 Real GDP growth rate (\%)

\begin{tabular}{|c|c|c|c|c|c|c|c|c|c|c|c|}
\hline Country & 2003 & 2004 & 2005 & 2006 & 2007 & 2008 & 2009 & 2010 & 2011 & 2012 & 2013 \\
\hline Austria & 0.8 & 2.7 & 2.1 & 3.4 & 3.6 & 1.5 & -3.8 & 1.9 & 3.1 & 0.9 & 0.2 \\
\hline Belgium & 0.9 & 3.4 & 1.9 & 2.6 & 3 & 1 & -2.6 & 2.5 & 1.6 & 0.1 & 0.3 \\
\hline Bulgaria & 5.4 & 6.6 & 6 & 6.5 & 6.9 & 5.8 & -5 & 0.7 & 2 & 0.5 & 1.1 \\
\hline Croatia & 5.6 & 4.1 & 4.2 & 4.8 & 5.2 & 2.1 & -7.4 & -1.7 & -0.3 & -2.2 & -0.9 \\
\hline Cyprus & 2.8 & 4.4 & 3.9 & 4.5 & 4.9 & 3.6 & -2 & 1.4 & 0.3 & -2.4 & -5.4 \\
\hline Czech Rep. & 3.6 & 4.9 & 6.4 & 6.9 & 5.5 & 2.7 & -4.8 & 2.3 & 2 & -0.8 & -0.7 \\
\hline Denmark & 0.4 & 2.6 & 2.4 & 3.8 & 0.8 & -0.7 & -5.1 & 1.6 & 1.2 & -0.7 & -0.5 \\
\hline Estonia & 7.5 & 6.5 & 9.5 & 10.4 & 7.9 & -5.3 & -14.7 & 2.5 & 8.3 & 4.7 & 1.6 \\
\hline Finland & 2.0 & 3.9 & 2.8 & 4.1 & 5.2 & 0.7 & -8.3 & 3 & 2.6 & -1.5 & -1.2 \\
\hline France & 0.8 & 2.8 & 1.6 & 2.4 & 2.4 & 0.2 & -2.9 & 2 & 2.1 & 0.3 & 0.3 \\
\hline Germany & -0.7 & 1.2 & 0.7 & 3.7 & 3.3 & 1.1 & -5.6 & 4.1 & 3.6 & 0.4 & 0.1 \\
\hline Greece & 6.6 & 5 & 0.9 & 5.8 & 3.5 & -0.4 & -4.4 & -5.4 & -8.9 & -6.6 & -3.9 \\
\hline Hungary & 3.8 & 4.8 & 4.3 & 4 & 0.5 & 0.9 & -6.6 & 0.8 & 1.8 & -1.5 & 1.5 \\
\hline Ireland & 3 & 4.6 & 5.7 & 5.5 & 4.9 & -2.6 & -6.4 & -0.3 & 2.8 & -0.3 & 0.2 \\
\hline Italy & 0.2 & 1.6 & 0.9 & 2 & 1.5 & -1 & -5.5 & 1.7 & 0.6 & -2.3 & -1.9 \\
\hline Latvia & 8.6 & 8.9 & 10.2 & 11.6 & 9.8 & -3.2 & -14.2 & -2.9 & 5 & 4.8 & 4.2 \\
\hline Lithuania & - & - & - & 7.4 & 11.1 & 2.6 & -14.8 & 1.6 & 6.1 & 3.8 & 3.3 \\
\hline Luxembourg & 1.2 & 4.9 & 4.1 & 4.9 & 6.5 & 0.5 & -5.3 & 5.1 & 2.6 & -0.2 & 2 \\
\hline Malta & 2.5 & 0.4 & 3.8 & 1.8 & 4 & 3.3 & -2.5 & 3.5 & 2.2 & 2.5 & 2.5 \\
\hline Netherlands & 0.3 & 1.9 & 2.3 & 3.8 & 4.2 & 2.1 & -3.3 & 1.1 & 1.7 & -1.6 & -0.7 \\
\hline Poland & 3.6 & 5.1 & 3.5 & 6.2 & 7.2 & 3.9 & 2.6 & 3.7 & 4.8 & 1.8 & 1.7 \\
\hline Portugal & -0.9 & 1.8 & 0.8 & 1.6 & 2.5 & 0.2 & -3 & 1.9 & -1.8 & -3.3 & -1.4 \\
\hline Romania & 5.5 & 8.4 & 4.2 & 8.1 & 6.9 & 8.5 & -7.1 & -0.8 & 1.1 & 0.6 & 3.4 \\
\hline Slovakia & 5.4 & 5.2 & 6.5 & 8.3 & 10.7 & 5.4 & -5.3 & 4.8 & 2.7 & 1.6 & 1.4 \\
\hline Slovenia & 2.8 & 4.4 & 4 & 5.7 & 6.9 & 3.3 & -7.8 & 1.2 & 0.6 & -2.6 & -1 \\
\hline Spain & 3.2 & 3.2 & 3.7 & 4.2 & 3.8 & 1.1 & -3.6 & 0 & -0.6 & -2.1 & -1.2 \\
\hline Sweden & 2.4 & 4.3 & 2.8 & 4.7 & 3.4 & -0.6 & -5.2 & 6 & 2.7 & -0.3 & 1.3 \\
\hline United Kingdom & 4.3 & 2.5 & 2.8 & 3 & 2.6 & -0.3 & -4.3 & 1.9 & 1.6 & 0.7 & 1.7 \\
\hline EU28 & 1.5 & 2.5 & 2 & 3.4 & 3.1 & 0.5 & -4.4 & 2.1 & 1.7 & -0.4 & 0 \\
\hline
\end{tabular}

Source: EUROSTAT

In Southern European countries, job destruction is not only a consequence of the crisis; it is also the outcome of the peculiarities of the labour market in those countries, which preceded the economic crisis. Firstly, Southern European countries are characterized by strong labour market fragmentation. This means that the level of worker protection varies greatly according to whether employees are under permanent or temporary contracts. The high level of protection afforded to permanent workers and, in parallel, the high level of vulnerability experienced by temporary workers has led to significant volatility in the labour market: contracting on a fixedterm basis has been seen to expand during periods of economic boom, and intensive job destruction has been seen to occur during times of economic crisis 
Table 11.2 Annual average unemployment rates (\%)

\begin{tabular}{|c|c|c|c|c|c|c|c|c|c|c|c|}
\hline Country & 2003 & 2004 & 2005 & 2006 & 2007 & 2008 & 2009 & 2010 & 2011 & 2012 & 2013 \\
\hline Austria & 4.3 & 4.9 & 5.2 & 4.8 & 4.4 & 3.8 & 4.8 & 4.4 & 4.2 & 4.3 & 4.9 \\
\hline Belgium & 8.2 & 8.4 & 8.5 & 8.3 & 7.5 & 7.0 & 7.9 & 8.3 & 7.2 & 7.6 & 8.4 \\
\hline Bulgaria & 13.7 & 12.1 & 10.1 & 9 & 6.9 & 5.6 & 6.8 & 10.3 & 11.3 & 12.3 & 13.0 \\
\hline Croatia & 14.2 & 13.9 & 13.0 & 11.6 & 10 & 8.9 & 9.6 & 12.3 & 13.9 & 16.1 & 17.3 \\
\hline Cyprus & 4.1 & 4.6 & 5.3 & 4.6 & 3.9 & 3.7 & 5.4 & 6.3 & 7.9 & 11.9 & 15.9 \\
\hline Czech Rep. & 7.8 & 8.3 & 7.9 & 7.1 & 5.3 & 4.4 & 6.7 & 7.3 & 6.7 & 7.0 & 7.0 \\
\hline Denmark & 5.4 & 5.5 & 4.8 & 3.9 & 3.8 & 3.4 & 6.0 & 7.5 & 7.6 & 7.5 & 7.0 \\
\hline Estonia & 10.3 & 10.1 & 8.0 & 5.9 & 4.6 & 5.5 & 13.5 & 16.7 & 12.3 & 10.0 & 8.6 \\
\hline Finland & 9.0 & 8.8 & 8.4 & 7.7 & 6.9 & 6.4 & 8.2 & 8.4 & 7.8 & 7.7 & 8.2 \\
\hline France & 8.6 & 8.9 & 8.9 & 8.8 & 8.0 & 7.4 & 9.1 & 9.3 & 9.2 & 9.8 & 10.3 \\
\hline Germany & 9.7 & 10.4 & 11.2 & 10.1 & 8.5 & 7.4 & 7.6 & 7.0 & 5.8 & 5.4 & 5.2 \\
\hline Greece & 9.7 & 10.6 & 10.0 & 9.0 & 8.4 & 7.8 & 9.6 & 12.7 & 17.9 & 24.5 & 27.5 \\
\hline Hungary & 5.8 & 6.1 & 7.2 & 7.5 & 7.4 & 7.8 & 10.0 & 11.2 & 11.0 & 11.0 & 10.2 \\
\hline Ireland & 4.6 & 4.5 & 4.4 & 4.5 & 4.7 & 6.4 & 12.0 & 13.9 & 14.7 & 14.7 & 13.1 \\
\hline Italy & 8.4 & 8.0 & 7.7 & 6.8 & 6.1 & 6.7 & 7.8 & 8.4 & 8.4 & 10.7 & 12.2 \\
\hline Latvia & 11.6 & 11.7 & 10.0 & 7.0 & 6.1 & 7.7 & 17.5 & 19.5 & 16.2 & 15.0 & 11.9 \\
\hline Lithuania & 12.4 & 10.9 & 8.3 & 5.8 & 4.3 & 5.8 & 13.8 & 17.8 & 15.4 & 13.4 & 11.8 \\
\hline Luxembourg & 3.8 & 5.0 & 4.6 & 4.6 & 4.2 & 4.9 & 5.1 & 4.6 & 4.8 & 5.1 & 5.9 \\
\hline Malta & 7.7 & 7.2 & 6.9 & 6.8 & 6.5 & 6.0 & 6.9 & 6.9 & 6.4 & 6.3 & 6.4 \\
\hline Netherlands & 4.2 & 5.1 & 5.3 & 4.4 & 3.6 & 3.1 & 3.7 & 4.5 & 4.4 & 5.3 & 6.7 \\
\hline Poland & 19.8 & 19.1 & 17.9 & 13.9 & 9.6 & 7.1 & 8.1 & 9.7 & 9.7 & 10.1 & 10.3 \\
\hline Portugal & 7.4 & 7.8 & 8.8 & 8.8 & 9.2 & 8.7 & 10.7 & 12.0 & 12.9 & 15.8 & 16.4 \\
\hline Romania & 7.7 & 8 & 7.1 & 7.2 & 6.4 & 5.6 & 6.5 & 7.0 & 7.2 & 6.8 & 7.1 \\
\hline Slovakia & 17.7 & 18.4 & 16.4 & 13.5 & 11.2 & 9.6 & 12.1 & 14.5 & 13.7 & 14.0 & 14.2 \\
\hline Slovenia & 6.7 & 6.3 & 6.5 & 6.0 & 4.9 & 4.4 & 5.9 & 7.3 & 8.2 & 8.9 & 10.1 \\
\hline Spain & 11.5 & 11.0 & 9.2 & 8.5 & 8.2 & 11.3 & 17.9 & 19.9 & 21.4 & 24.8 & 26.1 \\
\hline Sweden & 6.6 & 7.4 & 7.7 & 7.1 & 6.1 & 6.2 & 8.3 & 8.6 & 7.8 & 8.0 & 8.0 \\
\hline United Kingdom & 5.0 & 4.7 & 4.8 & 5.4 & 5.3 & 5.6 & 7.5 & 7.8 & 8.1 & 7.9 & 7.6 \\
\hline EU28 & 9.1 & 9.2 & 9.0 & 8.2 & 7.2 & 7.0 & 8.9 & 9.6 & 9.6 & 10.5 & 10.8 \\
\hline
\end{tabular}

Source: EUROSTAT

(Bentolila et al. 2012; Garibaldi and Tadde 2013). In addition, the fragmentation of the labour markets deepened during the economic crisis as a result of the structural reforms carried out by Southern European countries under pressure from financial markets and from international institutions and creditor countries within the European Union. Deregulation of the labour market aimed initially at boosting job creation has resulted in increasing temporality and instability of the most vulnerable categories of the economically active population, such as the young and women (Gutiérrez 2014; Moreira et al. 2015). On the other hand, the heavy dependence of Southern EU economies on labour-intensive and low-productivity jobs has also had 
a considerable impact on unemployment rates, as low added-value sectors were the most hard hit by the economic crisis in Europe (European Commission 2014).

Finally, rising unemployment has been accompanied by a considerable fall in salaries as a direct result of the competitiveness improvement strategies employed by Southern European governments, based mainly on cuts in labour costs (Fernández 2014). All in all, the perception of employment insecurity caused by intensive job destruction, the deterioration of welfare state provisions and, finally, worsening economic working conditions, has led to a generalized perception of a deprivation of professional aspirations and life expectations. All these factors combined have favoured the intensification of South-North mobility within the EU.

\subsection{Changes in European Migratory Flows}

\subsubsection{Historical Context}

Historically, migratory flows in Europe have been characterized by the displacement of workers from relatively underdeveloped rural areas of Northern, Eastern and Southern Europe. These workers were attracted to other countries and regions where vibrant economic development and urbanization favoured an increasing division of labour. This context historically triggered the demand for unskilled or semiskilled labour in growing economic sectors such as intensive agriculture, mining, construction and heavy industry. Nonetheless, the main destinations for European migrants from the mid-nineteenth century to the 1920s were the Americas and Australia. This trend changed with the economic development of Northern European countries in the first decade of the twentieth century, which coincided with significant reductions in fertility rates and the associated reduction in labour surpluses in these countries (Caselli et al. 2003). While Southern and Eastern European regions continued to lag behind, emigrants from those areas could now find in Northern Europe an alternative to trans-oceanic migration. For instance, of the 15 million Italians who emigrated between 1876 and 1920, nearly half (6.8 million) went to other European countries. Similarly, up to 2.4 million Polish migrants were employed as seasonal workers in the German Empire during the same period (Castles and Miller 2009). World War I-and the ethnic and political migration it triggered-as well as the growing restrictions on immigration in the Americas further reinforced this trend (Kirk 1969).

After World War II, the rebuilding of the North European economies in the late 1940s and the subsequent intensive economic growth supported by the development of heavy industries, manufacturing and construction triggered new migration. Indeed, those industries required an increasing amount of manpower that native workers could not entirely satisfy. Similarly to previous decades, the growing economies of Northern Europe relied on low-skilled migrants from less-developed countries and regions to meet the growing demand for labour. Two features characterized 
these post-war migration flows. First, the division of Europe caused by the Cold War reduced considerably the flow from Central and Eastern Europe countries, which had hitherto constituted a traditional reservoir of workers for Northern European countries (Fassmann and Münz 1994). This created a major dependence on workers from Southern Europe. Second, guest-worker programmes became the main modality of migration to Northern Europe after World War II. Although these programmes had existed before, it was really during the post-war period that stateled recruitment programmes began to shape the direction and volume of migratory flows (Olsson 1996).

Belgium, the United Kingdom and France were the first to start recruiting in Southern Europe by signing bilateral labour agreements with Italy in 1946 (see Chaps. 7, 8 and 10 of this volume). They were followed by the Netherlands and Switzerland a few years later (Akgündüz 2012). Interestingly, West Germanywhich became the largest destination country for guest workers-implemented these programmes only later. It was only following pressure from employers in the industrial sector that the West German government eventually agreed to take this route (Petersen 2006). These programmes would become the main channel through which Italian, Greek, Portuguese and Spanish workers migrated to Northern European countries in the 1950s, 1960s and the first half of the 1970s. Within Europe, Northern states therefore found in the rural South the necessary supply of labour for their economic recovery after World War II. According to rather conservative estimations made by Zimmermann (1996), from the beginning of the postwar migration until the early 1970s, approximately five million people migrated to Northern Europe from the Mediterranean countries (including Turkey). However, there are reasons to think that the flow was even larger. The total volume of flow from Spain in the period 1956-1971 was approximately 1.5 million (Akgündüz 2012). According to Venturini (2004), in the 1960s alone, over 2.3 million Italians emigrated to Northern Europe. Between 1965 and 1974, 1,218,000 Portuguese migrants moved abroad; of these, $63 \%$ headed to France (Baganha et al. 2005). Increasing demand for labour favoured the extension of guest-worker programmes to countries like Morocco and Turkey. Former colonial powers, like the United Kingdom, France and the Netherlands also adopted policies to facilitate a more intense migration from former colonial territories (Venturini 2004).

Over the years, economic development and urbanization in Southern Europe gradually reduced the pool of rural and unemployed populations in these areas. This trend was reinforced by the 1973 Oil Crisis, which put an end to the period of rapid economic expansion in Northern Europe and led these countries to abandon their guest-worker programmes. Nonetheless, contrary to government expectations, such a policy change did not lead to massive returns of Southern European guest workers.

In Southern Europe, the gradual improvement of social and economic conditions, the democratization processes in Greece, Portugal and Spain, along with weak inflow control and easy access to the shadow economy, started to attract immigration. Between 1973 and 1989, Southern Europe therefore turned from a major migrant-sending region into a receiving one (King 2000). In following years, 
intensification of immigration flows was accompanied by a considerable diversification of the origins with immigration from Central and Eastern Europe supplementing the earlier migratory waves (Peixoto et al. 2012). Migration from Central and Eastern Europe later intensified after the 2004 and 2007 enlargements of the European Union.

Initial migratory flows from Central and Eastern Europe were directed towards the United Kingdom and Ireland, and only later to other Northern EU Member States and Southern Europe. EU Labour Force Survey data also shows that within the 10 years following the $2004 \mathrm{EU}$ enlargement, the total number of EU12 nationals residing in the "old" Member States increased 5.4-fold, from 1.1 million in 2004 to 6.1 million in 2014. This number can be translated into a total net inflow of five million people from the New Member States (Fihel et al. 2015). Overall, the enlargement of the EU to Central and Eastern Europe contributed decisively to consolidating the East to West migratory route but also, and most importantly, to establishing a new East to South migratory route (Grzymała-Kazłowska 2013).

\subsubsection{Migratory Flows in the EU During the Economic Crisis}

The outbreak of the economic crisis changed considerably the patterns of intra-EU mobility. First of all, available data presented in the country chapters of this volume showed clear signs of a remarkable increase in South-North mobility, particularly between 2011 and 2012, when unemployment levels reached record high levels in Southern Europe. Data regarding stock and outflows from southern countries suggests that the main destinations for new Southern European migrants have been unsurprisingly, the UK and Germany. Data of inflows from these countries is consistent with this and also reports considerable increases in the numbers of Southern Europeans arriving at the beginning of the decade. The lesser importance of France as a receiving country, when compared to the role that it played decades ago, may very well be a consequence of its sluggish economic performance.

In addition, as mentioned in several chapters of this volume, empirical evidence suggests that large numbers of New Member State nationals (for example Romanians in Spain, Albanians in Greece) and Latin Americans, who once migrated to Southern Europe, are currently returning home or re-emigrating towards different EU Member States. Finally, it can be observed that the Southern European countries (and Ireland) have lost their power of attraction for migratory flows. Although in the case of Italy and Spain, migratory flows from New Member States have continued, their intensity has been significantly lower when compared with the pre-crisis period. By contrast, Austria, Belgium, Denmark, Germany and the United Kingdom represent the cluster of countries where the numbers of recently arrived (post-crisis) migrants are larger in relative terms than those that arrived between 2003 and 2007. This is related to increasing flows from the crisis-hit Southern Europe and also to renewed migration from New Member States (Fihel et al. 2015) (Table 11.3). 
Table 11.3 Percentages of EU28 nationals living abroad in 2012 by period of arrival to country of residence

\begin{tabular}{l|l|l|l}
\hline Country of residence & $1985-2002$ & $2003-2007$ & $2008-2012$ \\
\hline Austria & 61.71 & 16.02 & 22.27 \\
\hline Belgium & 59.29 & 15.14 & 25.57 \\
\hline Bulgaria & 76.19 & 4.76 & 19.05 \\
\hline Croatia & 91.69 & 5.45 & 2.86 \\
\hline Cyprus & 33.11 & 22.12 & 44.77 \\
\hline Czech Republic & 83.31 & 9.5 & 7.18 \\
\hline Denmark & 39.3 & 17.94 & 42.76 \\
\hline Estonia & 72.37 & 12.5 & 15.13 \\
\hline Finland & 58.69 & 17.38 & 23.93 \\
\hline France & 81.08 & 9.26 & 9.66 \\
\hline Germany+ & 64.02 & 12.69 & 23.29 \\
\hline Greece & 54.97 & 25.83 & 19.2 \\
\hline Hungary & 72.54 & 14.31 & 13.16 \\
\hline Ireland & 38.63 & 33.97 & 27.4 \\
\hline Italy & 50.27 & 33.48 & 16.25 \\
\hline Latvia & 89.58 & 3.1 & 7.32 \\
\hline Lithuania & 84.77 & 5.96 & 9.27 \\
\hline Luxembourg & 59.89 & 16.27 & 23.84 \\
\hline Malta & 71.22 & 15.11 & 13.67 \\
\hline Netherlands & 73.09 & 14.8 & 12.11 \\
\hline Poland & 77.04 & 6.46 & 16.50 \\
\hline Portugal & 72.95 & 16.42 & 10.64 \\
\hline Romania & 87.5 & 6.25 & 6.25 \\
\hline Slovakia & 90.24 & 2.66 & 7.1 \\
\hline Slovenia & 91.88 & 2.38 & 5.74 \\
\hline Spain & 54.03 & 32.87 & 13.1 \\
\hline Sweden & 74.99 & 11.62 & 13.39 \\
\hline United Kingdom & 43.8 & 23.45 & 32.75 \\
\hline Sorce: EUROSTAT & &
\end{tabular}

Source: EUROSTAT (EU-LFS Survey)

\subsubsection{Past and Current South-North Flows: Why History Is Not Repeating Itself}

The authors of the country chapters of this volume referred frequently to the controversy regarding the size of the phenomenon under study. On the one hand, it seems that, despite the duration and the harshness of the crisis in Southern EU countries, the overall volume of South-North migration could be considered relatively low if compared with the migrations of the 1950s, 1960s and 1970s, with the sole exception of Portugal. On the other hand, data limitations pose the question of whether the real numbers of outflows and inflows are greatly underestimated by the available official statistics. Particularly puzzling is the estimation of the real size of both circular and unregistered migration. 
Nevertheless, under the free movement of the labour force granted within the European Union by the Treaty, and given the staggering unemployment rates observed in the South, one might expect higher rates of internal migratory flows, even in the official statistics. One plausible explanation for these otherwise "surprisingly" low levels of current South to North migratory flows arises when considering that international migration is often yet another form of rural to urban migration of the young and the middle aged. Due to past declines in fertility rates (see Billari and Kohler 2004; Frejka and Sardon 2004), the size of the 20-34 year old cohorts in South Europe decreased substantially between 1965 and 2014 (to around 2.4 million smaller in Spain and 0.7 million smaller in Italy). Moreover, as Southern European countries are now far more urbanized than in the post-war context, this driver of Southern European migration has also lost momentum (Heikkilä and Kashinoro 2009). Over time, these demographic changes that have affected Southern Europe since the 1970s have contributed to a significant reduction in the pool of potential migrants from this region of Europe.

In addition to this, one must also bear in mind that current potential southern migrants often lack informal networks of their fellow countrymen in the destination countries, and this limits their ability to establish a foothold there. Demographic changes in the South of Europe must thus be related to the lack of availability of family networks in destination countries for younger generations of potential southern migrants. Young unemployed southerners are no longer concentrated in rural areas lacking basic services, as they were during the post-war years, but instead live in well-equipped urban towns and cities, quite often in parental households. Their parents did not migrate to northern countries, or else they returned long ago, leaving no strong links there. Consequently, nowadays, typically southern family networks favour staying at home to cope with unemployment or they take on precarious employment rather than migrating. On the other hand, if they do migrate, this may be only temporarily, while remaining registered as residents in the parental household of the native country in order to avoid losing welfare benefits, such as free and straightforward access to public health care.

There is a well-documented literature on the impact of transnational networks on migration flows and patterns of labour market incorporation. At the individual or household level, support from ethnic networks reduces the costs of migration and adaptation into the host society and labour market. At the macro-social level, these networks determine the direction and intensity of migration flows (Gurak and Caces 1992; Espinosa and Massey 1999). However, as established in the literature, the durability of transnational links is a critical condition for networks to play a role for newcomers. When there are important time gaps between migration waves, the links between old and new migration waves may be weak. In this case, the links between migrant communities and the home country can become purely symbolic and therefore of little use for the socio-economic integration of newcomers (Bruneau 2010). In this regard, the case of post-crisis Southern European migration is very illustrative. The gradual decrease in the volume of emigration from Italy, Spain and Greece after the 1970s Oil Crisis created a considerable time gap between the post-war and the new cohorts of migrants. We believe that this missing generational link has contributed to keeping the volume of outflows from these countries relatively low. 
As shown in Chap. 6, Portugal offers a counter-example to this situation, as networks continue to play an important role in migration decisions and in the integration of newcomers into the labour market. The relevance of migration networks in the Portuguese case can be explained by the fact that migration from this country never ceased. This continuous migration maintained dense transnational connections between the emigrant communities and the home country. This data could explain the specificity of the Portuguese case compared to the other three Southern European case studies: new Portuguese migrants are comparatively more numerous and less skilled.

Southern Europeans lacking informal links (relatives or friends) with northern countries may find alternative strategies to cope with unemployment, such as staying within the parental household in the country of origin, waiting for a job opportunity, accepting work in the shadow economy or pursuing further education. In short, they opt for modalities of adaptation to the crisis that do not involve migration, or at least, not the type of (permanent) fully regularized migration that is reflected in official statistics.

Furthermore, one should not forget that northern countries have experienced a deep transformation of their economic structure with subsequent changes in labour force demand. The structure of demand for labour in Northern Europe is not the same as it was during the 1950s, 1960s and 1970s, either in quantitative or qualitative terms. Labour-intensive industries have, to a great extent, been delocalized, thus reducing employment opportunities for unskilled migrants. At the same time, many employment niches have appeared in the service sector for the low skilled (e.g., hospitality) and also for the better educated (e.g., health care, finance, engineering), particularly in the most dynamic Northern European labour markets (the UK, Germany). Northern European labour markets no longer require a massive migration of uneducated people to place in labour-intensive activities such as mining or heavy industry but rather workers with specific skills. Accordingly, successful insertion into these more competitive labour markets is only available to those migrants who respond to certain characteristics in terms of education, occupation and language proficiency. The low level of foreign language proficiency among Southern Europeans is therefore an important obstacle to their successful relocation in Northern Europe (see EU Skills Panorama 2014). Among the highly educated, some have specific skills that are needed in receiving Northern European countries. Others, however, do not have those skills, or simply lack adequate acceptable qualifications with which to demonstrate them. In addition, while the average educational level of young Southern European cohorts may have improved over the years, it often remains insufficient to meet the demands of Northern European employers in specific sectors (Lüdemann and Richter 2014). Finally, compared to the post-war context, Southern EU migrants are no longer the only ones to migrate to North Western Europe. Indeed, the growing presence of Eastern European and third country migrants has strongly mitigated the demand for Southern EU migrants over the years. As suggested by the available data, Central and Eastern European migrants occupy mostly low- and mid-skilled labour positions primarily in low value-added economic sectors (Kahanec and Kurekova 2014). Nonetheless, it should also be noted that in the post-enlargement period, the share of EU10 migrants with high 
educational attainment residing in the EU15 has increased substantially (Kahanec 2013). An examination of this data therefore suggests that an important number of workers accept jobs below their level of qualification.

The large volume of Central and Eastern EU migration to Northern EU Member States has consequences for the incorporation into the labour market of new Southern EU migrants who move to the same area. The concentration of Central and Eastern migrants in elementary occupations constitutes an important obstacle to the successful incorporation of new low-skilled migrants from Southern Europe. For this reason, the skills level is becoming an increasingly important factor driving the successful labour market integration of new Southern European migrants, as will be shown in the following section.

\subsection{Socio-demographic Composition of South European Migrants}

\subsubsection{Age Composition}

Data presented in the country chapters confirms that newly arrived South European migrants are of a particularly young age. Sources from sending southern countries report increasing proportions of people of a young age residing abroad, which is consistent with employment statistics from the main receiving countries, such as the UK or Germany, where sharp increases in the number of southerners finding a job there correlate with increases in the proportions of the "under 30 age group". We relate this trend, mentioned in previous sections of this chapter, to a strong "insideroutsider" fragmentation of the labour market, characteristic of Southern economies, whereby precarious employment is disproportionally more prevalent among the young, often irrespective of their educational attainment. As will be shown in the following sections, current South to North migration cannot be described as the result only of the movement of those with the lowest educational or occupational profiles, i.e., those who might consider migrating based on "push" factors. Though this sort of migration may describe the circumstances of the majority of Portuguese or Greek migrants to the UK, it does not reflect accurately the circumstances of most Italians and Spaniards (see Chap. 10 of this volume) and it does not explain why many well-educated Greeks are moving abroad. In fact, the data suggests that migration is becoming a strategy adopted by an increasing number of young welleducated southerners, who move north seeking better career prospects and professional development, neither of which is available at home. The crisis has exacerbated the negative effects on the employability of the young in the segmented Southern European labour markets, which have always been unfriendly towards them. From this perspective, and as will be argued in the concluding sections of this chapter, the migration of skilled South Europeans to Northern Europe may not be regarded 
exclusively as a new form of "brain drain" but rather as a response by skilled professionals to avoid their own "brain waste".

\subsubsection{Educational Attainment}

New Southern European migrants are not only fewer in number than during the post-war context, they also constitute a more diverse group. As Table 11.4 shows, an increasing proportion of these migrants are skilled professionals. Indeed, the

Table 11.4 Percentages of EU28 migrant population by level of education

\begin{tabular}{l|l|l|l|l|l|l}
\hline \multirow{2}{*}{$\begin{array}{l}\text { Country of } \\
\text { residence }\end{array}$} & University & Secondary & Primary & University & Secondary & Primary \\
\hline Austria & 2007 & 2007 & 2007 & 2012 & 2012 & 2012 \\
\hline Belgium & 23.5 & 55.74 & 20.76 & 24.5 & 57.06 & 18.44 \\
\hline Bulgaria & 27.97 & 29.06 & 42.98 & 30.75 & 30.63 & 38.62 \\
\hline Croatia & 20.27 & 25.68 & 54.05 & 37.5 & 18.75 & 43.75 \\
\hline Cyprus & - & - & - & 24.06 & 45.45 & 30.48 \\
\hline Czech Republic & 34.26 & 38.39 & 27.35 & 33.4 & 42.49 & 24.11 \\
\hline Denmark & 9.59 & 57.13 & 33.27 & 12.96 & 55.53 & 31.51 \\
\hline Estonia & 39.38 & 39.18 & 21.44 & 39.84 & 35.3 & 24.85 \\
\hline Finland & 42.99 & 38.32 & 18.69 & 51.54 & 33.85 & 14.62 \\
\hline France & - & - & - & 26.82 & 41.67 & 31.52 \\
\hline Germany+ & 15.92 & 23.92 & 60.16 & 19.23 & 26.94 & 53.83 \\
\hline Greece & 17.72 & 40.43 & 41.85 & 22.17 & 44.29 & 33.54 \\
\hline Hungary & 20.05 & 49.76 & 30.18 & 20.53 & 46.65 & 32.83 \\
\hline Ireland & 17.67 & 51.36 & 30.97 & 25.64 & 52.08 & 22.28 \\
\hline Italy & 33.98 & 36.65 & 29.37 & 36.73 & 35.42 & 27.85 \\
\hline Latvia & 12.46 & 46.89 & 40.65 & 10.94 & 50.34 & 38.72 \\
\hline Island* & 15.63 & 44.37 & 40 & 18.16 & 47.26 & 34.58 \\
\hline Lithuania & 30.99 & 37.14 & 31.87 & 28.41 & 47.02 & 24.57 \\
\hline Luxembourg & 25.13 & 50.8 & 24.06 & 32.62 & 58.16 & 9.22 \\
\hline Malta & 25.39 & 30.48 & 44.13 & 39.78 & 30.17 & 30.05 \\
\hline Netherlands & - & - & - & 17.77 & 31.75 & 50.47 \\
\hline Poland & 30.25 & 50.71 & 19.04 & 37.09 & 36.41 & 26.5 \\
\hline Portugal & 9.75 & 45.05 & 45.2 & 15.12 & 42.25 & 37.63 \\
\hline Romania & 24.44 & 29.52 & 46.03 & 24.65 & 33.43 & 41.91 \\
\hline Slovakia & 49.06 & 30.19 & 20.75 & 19.05 & 35.71 & 45.24 \\
\hline Slovenia & 17.41 & 60.15 & 22.44 & 25.57 & 60.5 & 13.93 \\
\hline Spain & 25.29 & 54.6 & 20.11 & 23.26 & 54.04 & 22.69 \\
\hline Sweden & 26.37 & 34.11 & 39.52 & 27.1 & 33.28 & 39.62 \\
\hline United Kingdom & 30.31 & 41.24 & 28.45 & 33.3 & 38.85 & 27.85 \\
\hline Sourc: EUR. & 26.71 & 52.04 & 21.25 & 40.77 & 40.05 & 19.18 \\
\hline (EU & & & & & \\
\hline STA & & & & & \\
\hline
\end{tabular}

Source: EUROSTAT (EU-LFS Survey) 
educational composition of EU28 migrants has changed significantly during the crisis. Between 2007 and 2012, a general reduction in the stock of EU28 migrants with only primary education is observed in favour of an increase in the stocks of those with a secondary and a university education. However, this shift has not taken place equally in all countries. While the United Kingdom and Luxembourg seem to have specialized in attracting the highly educated (and reducing the proportion of both those with a primary and a secondary education in their labour markets), other countries seem to have attracted workers with both a secondary and a university education (Germany, France, Belgium).

Available Eurostat statistics do not differentiate between Eastern and Southern Europeans. Nevertheless, the country chapters in this volume, as well as other recent studies, do provide relevant data suggesting that the presence of highly-educated young professionals is above average among South Europeans. This is particularly the case among Italians and Spaniards (see Kaczmarczyk and Stanek 2015). In Germany, as explained in Chap. 9 of this volume, this has been caused by a significant increase in the demand for highly qualified labour, which, to date, has not been satisfied by introducing either national level recruitment schemes or EU-level regulations, such as the introduction of the EU Blue Card (see Cerna and Czaika 2015) However, the volume of flows has failed to match the expectations of governments and employers, and numbers are far below those observed in the UK. Available data discussed in the country chapters on Italy and Spain also confirms a considerable increase in the total number and proportion of highly-educated people migrating to Northern Europe. This trend should not hide the fact that the unskilled still represent an important share of South to North migratory flows (about one third in Germany and in the UK). In fact, there is some controversy over the extent to which migration of unskilled migrants is going largely "undetected" by official statistics, given the allegedly higher tendency among the low educated to work in the shadow economy or as self-employed and to avoid de-registering as residents in their home countries. Nevertheless, taking all these considerations together, it is evident that an increasingly large number of southerners with a university degree are moving north.

Even though the higher levels of education of southern migrants may partly reflect the increase in the overall educational level of the young cohorts, other factors can also be identified to explain the growing presence of the highly educated among those who leave Southern Europe. Indeed, we believe that this trend reveals an increasing selectivity in current migratory flows, which we attribute to changes in labour demand. These changes are related firstly, to the ever-growing importance of knowledge-based sectors in the economic structure of Northern European countries and secondly, to changes in the socio-demographic characteristics of young Southern Europeans. As mentioned in previous sections of this chapter, low-educated Southern Europeans lack informal networks in the main destination countries, whose presence might otherwise ease their entrance into local labour markets. Moreover, competition from Eastern and Central Europeans also constitutes a major factor that limits job opportunities for unskilled southerners. Furthermore, a large number of these unskilled Southern Europeans can count on alternative strategies to migration, since the conditions in southern countries have improved with respect to 
the decades prior to the Oil Crisis. Unemployment benefits, parental help, employment in the shadow economy or the pursuit of further education can be reasonable alternatives to migration, at least for a period of time. Highly skilled young Southern Europeans, by contrast, do have clearer incentives to migrate to northern countries. There, the demand for labour is more suited to their skills, making them less dependent on informal networks for their insertion into the labour market. In addition, as mentioned previously, career prospects in the typically fragmented labour markets of Southern European countries, where young people are often marginalized as "outsiders" regardless of their educational attainment, have worsened considerably during the crisis, making them more open to the idea of migrating. All these factors may have contributed to keeping the levels of migration from South to North relatively low in absolute numbers while favouring an increase in the proportion of the highly educated.

\subsubsection{Employment and Occupational Status of South European Migrants}

As indicated previously, the outbreak of the economic crisis had negative consequences on the labour market all over the EU. However, the duration and scale of the deterioration of employment opportunities among EU28 migrants has varied considerably from country to country. Data presented in Table 11.5 indicates that unemployment among EU28 migrants has decreased in Germany (as well as among its native population), increased moderately in France, Belgium, Luxembourg, the United Kingdom, Sweden, the Netherlands and Denmark and has increased sharply in Southern European countries (especially in Greece and Spain but less in Italy) and in Ireland.

It is worth mentioning that Belgium, Germany and the United Kingdom have not seen a major increase in EU28 migrant unemployment, despite being the three countries where the stock of EU28 migrants has increased the most since the beginning of the crisis. Particularly interesting is the case of the United Kingdom. This country seems to have become a remarkably attractive destination for EU nationals, who look for better opportunities outside their native countries, a situation confirmed by data provided in the country chapters on the UK, Italy and Spain. In the UK, the proportion of EU28 immigrants arriving between 2007 and 2012 constituted $32.7 \%$, although unemployment amongst this group has not increased significantly.

Although sufficient data is lacking in order to fully assess the labour market attainments of the different educational categories of new Southern EU migrants in Northern EU countries, data presented in the country chapters draws a picture of increasing diversity. While low-educated migrants seem to have a poor chance of successful labour market insertion in Germany, the highly skilled may integrate 
Table 11.5 Percentages of EU28 migrant population by employment status

\begin{tabular}{l|l|l|l|l}
\hline & Employed & Unemployed & Employed & Unemployed \\
\cline { 2 - 5 } Country of residence & 2007 & 2007 & 2012 & 2012 \\
\hline Austria & 50.58 & 2.92 & 54.52 & 3.03 \\
\hline Belgium & 49.47 & 4.54 & 51.31 & 5.3 \\
\hline Bulgaria & 13.51 & 2.7 & 12.5 & 6.25 \\
\hline Croatia & - & - & 33.96 & 7.49 \\
\hline Cyprus & 56.67 & 3.73 & 60.14 & 10.32 \\
\hline Czech Republic & 43.55 & 4.97 & 37.57 & 4.99 \\
\hline Denmark & 63.78 & 3.29 & 62.85 & 7.51 \\
\hline Estonia & 66.97 & 0 & 50 & 5.97 \\
\hline Finland & - & - & 73.18 & 6.36 \\
\hline France & 43.84 & 3.71 & 44.17 & 4.1 \\
\hline Germany & 61.02 & 6.73 & 63.97 & 4.85 \\
\hline Greece & 58.77 & 5.22 & 50.5 & 17.02 \\
\hline Hungary & 42.55 & 2.63 & 43.75 & 4.88 \\
\hline Ireland & 69.46 & 4.14 & 57.19 & 12.49 \\
\hline Italy & 55.14 & 5.23 & 55.51 & 8.63 \\
\hline Latvia & 44.51 & 3.99 & 32.63 & 6.53 \\
\hline Lithuania & 51.34 & 1.07 & 55.32 & 4.96 \\
\hline Luxembourg & 59.73 & 2.48 & 64.66 & 3.39 \\
\hline Malta & - & - & 41 & 4.98 \\
\hline Netherlands & 66.65 & 2.78 & 71.75 & 5.53 \\
\hline Poland & 13 & 0.74 & 14.27 & 1.16 \\
\hline Portugal & 61.08 & 4.89 & 58.33 & 11.93 \\
\hline Romania & 49.06 & 1.89 & 16.67 & 0 \\
\hline Slovakia & 46.23 & 1.93 & 37.44 & 3.65 \\
\hline Slovenia & 41.38 & 0.57 & 40.09 & 4.01 \\
\hline Spain & 63.27 & 7.16 & 48.98 & 21.15 \\
\hline Sweden & 68.73 & 4.09 & 66.06 & 6.26 \\
\hline United Kingdom & 61.93 & 3.57 & 61.85 & 4.58 \\
\hline SOurce: EUROSTAT & & &
\end{tabular}

Source: EUROSTAT (EU-LFS Survey)

rather well. This is particularly the case for those recruited by the various agencies operating to attract highly skilled professionals into the German labour market, providing they acquire the necessary proficiency in the German language. The UK seems to be the most attractive country for migrants of all educational levels. Its particularly dynamic labour market, combined with the fact that English is the lingua franca in today's Europe, constitute two powerful elements of attraction for job seekers from all regions of the world. However, not all highly skilled migrants do find jobs appropriate to their level of education, particularly during the first year after arrival. Many find themselves working in low-profile jobs in the retail or hospitality sectors and a non-negligible number of them do return to their home countries after 1 or 2 years. This may be a disappointing outcome for these migrants, or 
it may be what they initially expected. During their stay in the UK, many southern migrants acquire the employment experience and proficiency in the English language that will help them to find a job back in their home country, where initial access to the labour market is particularly harsh for the young and inexperienced. Among those with a secondary level education, some may very well find better career prospects in the UK than in Germany, if their profiles match the gaps left by the British educational system. Indeed, demand for certain types of professionals in the UK in the health care and construction sectors is closely related to a lack of vocational training in these areas. Foreign workers holding qualifications in these fields have traditionally been welcomed into the British labour marked for many decades and many southerners had been profiting from this, way before the beginning of the crisis.

\subsection{Concluding Remarks: From Old Routes of Mass Migration to New Routes of Individual Mobility}

The economic downturn in the Southern European countries has undoubtedly contributed to the transformation of migration patterns in Europe in recent years. The most salient changes are, firstly, the drastic reduction in migration flows to Southern EU Member States and secondly, the increase in flows of South European nationals to Northern European countries. Associated with the first of these changes, there has been an important increase in former migrants to Southern Europe who either return home (mainly to Latin America or Eastern Europe) or re-emigrate to Northern Europe. Though Southern Europeans never ceased completely from migrating north (particularly the Portuguese), and flows from South to North had already begun to rise during the years prior to the financial crisis, there is scant evidence that the effects of the financial crisis on employment rates in southern countries has greatly exacerbated the trend.

A more controversial issue is the discussion over the magnitude and nature of this trend. As mentioned above, flows of South to North migration are fuelled not only by migrants born in Southern Europe but also by people born in Eastern European or Latin American countries re-emigrating in order to seek better employment opportunities. Often, these migrants move north while holding on to their Southern EU Member State passports. In addition, many native Southern Europeans are known to migrate to Northern Europe without de-registering as residents in their home countries, or else they move only on a seasonal basis. Such circumstances, among many others, contribute to make current official statistics insufficient to assess the real size and nature of current South to North migratory flows.

Although some parallels may be established between current South to North flows and those occurring prior to the Oil Crisis in the mid-1970s, the overall intensity and nature of the new trend are quite different. Southern European migrants have changed along with the socio-economic and demographic reality of the South. 
Nowadays, southern migrants are mainly young and much better educated than their fellow countrymen who migrated during the 1950s, 1960s and 1970s. The causes triggering migration are also of a different nature. Current southerners do not come from the typical underdeveloped rural areas which were reservoirs of migratory outflows in the past, nor are they being recruited on a massive scale as cheap unskilled labour by employers of the manufacturing and extractive industries of northern countries. The mechanisms operating behind the increase in the number of southerners migrating north are a bit more complex than those that triggered past migratory flows between the rural South and the industrialized urban North. Clearly, the dramatic rises in unemployment levels in the South, particularly among the young, are the cornerstone of the story. The segmentation of the labour market has intensified during the crisis, causing many youngsters to lose their jobs and leaving closed for many more the doors leading to employment. And this is for an undetermined period of time and with bleak prospects for developing a professional career, particularly for the highly educated.

Current migratory flows may be greater in volume than observed in the official statistics, but they are still not comparable in size to the mass migration of the postwar decades. By contrast to the past European South-North flows, current migrations are no longer collectively organized by bilateral agreements between sending and receiving countries in order to satisfy the demands of labour-intensive sectors of the economy. Technological innovation and globalization, along with the development of national-specific institutional settings governing the labour markets in northern countries, have created a much more complex landscape of opportunities and employment niches for potential migrants from Southern Europe and other parts of the EU. Thus, the successful integration into the receiving country's labour market is increasingly dependent on whether immigrant profiles match the specific demands of the receiving country. This reduces the opportunities for unskilled southerners, who have been the most hardly hit by the increase in unemployment rates in Southern Europe. It also puts extra pressure on the highly educated, who must adjust to specific skills requirements resulting from high specialization in high value-added sectors typical of Northern European economies. Moreover, potential southern migrants nowadays constitute a group less prone to migration, since they can gain little benefit from solid migrant networks in destination countries, due to the generational gap between post-war and current migration waves. In fact, family or informal networks may be more available if they opt to stay in their home country, where living conditions are far better than before the Oil Crisis of the 1970s. Last but not least, the presence of large numbers of Eastern Europeans in the labour markets of Northern European countries constitutes stark competition for available jobs, which limits considerably the potential demand for southern labour.

Regarding the nature of the current intra-European South-North migrations, there is growing evidence showing that an important share of these flows is of temporary or circular nature (see Chap. 5 in this volume). Although this characteristic may appear similar to post-war migrations of Southern European guest workers, differences in the institutional and economic contexts force us to question the continuity between old and new migration patterns. At the time of guest worker 
programmes, the principal purpose was to ensure rotation by contracting workers for a limited periods, restricting family reunion (though not systematically) and permitting workers only to access specific economic sectors and occupations. As the employment and residency permits of foreign workers were renewable and labour demand remained high at least until the early 1970s, many Southern European workers stayed in the countries of destination over long periods of them. Many of them even decided to remain there after guest workers programs finally came to an end (Castles 1986). In the current context, the EU's freedom of movement, lowering costs of transportation and progress in communication technologies, along with the increasing deregulation of employment conditions, contributed to diversify mobility strategies as well as destinations of new Southern European migrants. In other words, South-North EU migrations, similarly to East-West migrations (Engbersen et al. 2013), now follow patterns of temporary and circular mobility rather than long-term migration patterns observed in the post-war period.

It is equally difficult to draw a clear analogy between the past guest worker programmes and the current situation of posted workers in the EU. First of all, as shown in Chaps. 3, 5 and 9, the volume of Southern European posted workers employed in Northern Europe is increasing but is still considerably lower than flows of guest workers during the post-war period. Second, unlike guest worker programmes in which sending and receiving countries' administrations were actively involved, the recruitment of posted workers is mainly managed by temporary staffing agencies or employers (Mottweiler et al. 2014). Furthermore, the recruitment of posted workers is not geographically limited but can occur throughout the EU. Overall, posted workers may enjoy greater autonomy and flexibility in their mobility strategies compared to post-war guest workers but, as shown in this volume, weaker public oversight also exposes them to greater difficulties when it comes to enforcing rules on their employment conditions or on their access to social protection.

Given these considerations, new South-North migration has become more selective and more dependent on individual initiative in contrast with previous decades, when it was mostly (although not exclusively) based on bilateral agreements and was organized on a rather collective basis. The flows are now more open, but they are also shaped by factors such as the migrant's skills characteristics as well as the specificities of the labour markets of receiving countries and the short-term performance of their economies. Thus, successful integration into the receiving country's labour market is increasingly dependent on whether immigrant profiles match the specific demands of the receiving country. Though routes for mass migration open to rural unskilled southerners do not seem to be operating, certain types of professionals may find clear pathways through which to move north, on an individual basis. Engineers seem to be welcomed in Germany, and analysts, managers and health care related professionals seem to be in high demand in the UK. Experienced construction workers and other types of semi-skilled professionals may also be able to find employment opportunities. The migration of such a large number of professionals might not be necessarily regarded as examples of "brain drain" but rather as individual responses to a lack of employment opportunities in the South, where the skills of the young are often disregarded by its segmented labour market. 
From this perspective, it is noteworthy to point to some dysfunctional features of the European Union, which limit mobility and discourage many potential migrants from moving abroad, or which favour mobility remaining in the shadows. Too often, national level institutional settings regulating the labour market contribute to the configuration of a rather rigid and fragmented European labour market. In addition, legislation regulating access to welfare and health care is not designed to suit the needs of migrant workers. A lot of work remains to be done by European institutions in order to ease these shortcomings. Bilateral agreements between EU Member States could contribute to easing the controversy regarding access to welfare by EU migrants. Reforming labour markets in the South and facilitating mechanisms to avoid "brain waste" while such reforms remain to be fully achieved should also be considered another priority for the near future of the EU Member States.

\section{References}

Akgündüz, A. (2012). Guest worker migration in post-war Europe (1946-1974): An analytical appraisal. In M. Martiniello \& J. Rath (Eds.), An introduction to international migration studies. European perspectives (pp. 181-209). Amsterdam: Amsterdam University Press (IMISCOE Series).

Baganha, M. I. B., Gois, P., \& Pereira, P. T. (2005). International migration from and to Portugal: What do we know and where are we going? In K. Zimmermann (Ed.), European migration: What do we know? Oxford: Oxford University Press.

Bentolila, S., Cahuc, P., Dolado, J. J., \& Le Barbanchon, T. (2012). Two-tier labour markets in the great recession: France versus Spain. The Economic Journal, 122(562), F155-F187. doi:10.1111/j.1468-0297.2012.02534.x.

Billari, F. C., \& Kohler, H.-P. (2004). Patterns of low and lowest-low fertility in Europe. Population Studies, 58(2), 161-176. doi:10.2307/4148227.

Bruneau, M. (2010). Diasporas, transnational spaces and communities. In R. Bauböck \& T. Faist (Eds.), Diaspora and transnationalism: Concepts, theories and methods (pp. 35-49). Amsterdam: Amsterdam University Press.

Canetta, E., Fries-Tersch E., \& Mabilia, V. (2014). 2014 annual report on labour mobility, Network Statistics FMSSFE. Brussels: European Commission.

Caselli, G., Vallin, J., \& Wunsch, G. (Eds.). (2003). Démographie: analyse et synthèse, t. 4: Les déterminants de la migration. Paris: INED.

Castles, S. (1986). The guest-worker in western Europe - An obituary. The International Migration Review, 20(4), 761-778. doi:10.2307/2545735.

Castles, S., \& Miller, M. J. (2009). The age of migration (4th ed.). Basingstoke: Palgrave MacMillan.

Castles, S., \& Vezzoli, S. (2009). The global economic crisis and migration: Temporary interruption or structural change? Paradigmes, 2, 69-75.

Cerna, L., \& Czaika, M. (2015). European policies to attract talent: The crisis and highly skilled migration policy changes. In A. Triandafyllidou \& I. Isaakyan (Eds.), High skill migration and recession: Gendered perspectives (pp. 22-43). Houndmills: Palgrave Macmillan.

Engbersen, G., Leerkes, A., Grabowska-Lusinska, I., Snel, E., \& Burgers, J. (2013). On the differential attachments of migrants from central and eastern Europe: A typology of labour migration. Journal of Ethnic and Migration Studies, 39(6), 959-981. doi:10.1080/13691 83X.2013.765663. 
Espinosa, K., \& Massey, D. S. (1999). Undocumented migration and the quantity and quality of social capital. In L. Pries (Ed.), Migration and translational social spaces. Research in ethnic relations (pp. 106-137). Hants: Ashgate Publishing.

European Commission. (2014). Employment: Vacancy trends reveal growing North-South divide in EU labour market. European, Commission Press Release (Vol. 24 February 2014). Brussels.

Fassmann, H., \& Münz, R. (1994). European east-west migration, 1945-1992. International Migration Review, 28(3), 520-538.

Fernández, M. J. (2014). Spain's internal devaluation and export growth. SEFO - Spanish Economic and Financial Outlook, 3(5), 45-52.

Fihel, A., Anna, J., Kaczmarczyk, P., \& Nestorowicz, J. (2015). Free movement of workers and transitional arrangements: Lessons from the 2004 and 2007 enlargements. Warsaw: Centre of Migration Research, University of Warsaw.

Frejka, T., \& Sardon, J.-P. (2004). Childbearing trends and prospects in low-fertility countries. A cohort analysis. Dordrecht: Kluwer Academic Publisher.

Garibaldi, P., \& Tadde, F. (2013). Italy: A dual labour market in transition. Country case study on labour market segmentation (ILO Employment Working Paper, Vol. 144). Geneva: International Labor Office.

Grzymała-Kazłowska, A. (2013). Migration and socio-demographic processes in central and eastern Europe: Characteristics, specificity and internal differences. Central and Eastern European Migration Review, 2, 5-11.

Gurak, D., \& Caces, F. (1992). Networks shaping migration systems. In M. M. Kritz, L. L. Lim, \& H. Zlotnik (Eds.), International migration systems. A global approach (pp. 150-189). Oxford: Clarendon Press.

Gutiérrez, R. (2014). Welfare performance in southern Europe: Employment crisis and poverty risk. South European Society and Politics, 19(3), 371-392. doi:10.1080/13608746.2014.948592.

Heikkilä, E., \& Kashinoro, H. (2009). Differential urbanization trends in Europe: The european case. In E. Elgar (Ed.), International handbook of urban policy (Issues in the Developed World, Vol. 2, pp. 25-45). Cheltenham: Edward Elgar Publishing Limited.

Kaczmarczyk, P., \& Stanek, M. (2015). Crisis and beyond: Intra-EU mobility of polish and spanish migrants in a comparative perspective. In A. Triandafyllidou \& I. Isaakyan (Eds.), High skill migration and recession: Gendered perspectives (pp. 69-100). Palgrave Macmillan: Houndmills.

Kahanec, M. (2013). Labor mobility in an enlarged European Union. In A. Constant \& K. F. Zimmermann (Eds.), International handbook on the economics of migration (pp. 137-152). Cheltenham: Edward Elgar Publishing.

Kahanec, M., \& Kurekova, L. (2014). Did post-enlargement labor mobility help the EU to adjust during the great recession? The case of Slovakia (IZA Discussion, Vol. 8249). Bonn: Institute for the Study of Labour.

Kahanec, M., \& Zimmermann, K. F. (Eds.). (2014). Labor migration, EU enlargement, and the great recession. Geneva: Springer.

Kahanec, M., Pytlikova, M., \& Zimmermann, K. F. (2014). The free movement of workers in an enlarged European Union: Institutional underpinnings of economic adjustment (IZA Discussion Papers, Vol. 8456). Bonn: Institute for the Study of Labour.

Karger, H. (2014). The bitter pill: Austerity, debt, and the attack on Europe's welfare states. Journal of Sociology \& Social Welfare, XLI(2), 33-53.

King, R. (2000). Southern Europe in the changing global map of migration. In R. King, G. Lazaridis, \& C. Tsartanidis (Eds.), Eldorado or fortess? Migration in Southern Europe. London: Macmillan.

Kirk, D. (1969). Europe's population in the interwar years. London: Taylor \& Francis.

Lüdemann, E., \& Richter, B. (2014). Youth unemployment in southern Europe - Result of the crisis or a flaw in the system? Focus on Economics, 43, 1-6. 
Matsaganis, M., \& Leventi, C. (2014). The distributional impact of austerity and the recession in Southern Europe. South European Society and Politics, 19(3), 393-412. doi:10.1080/1360874 6.2014.947700.

Moreira, A., Alonso Domínguez, Á., Antunes, C., Karamessini, M., Raitano, M., \& Glatzer, M. (2015). Austerity-driven labour market reforms in southern Europe: Eroding the security of labour market insiders. European Journal of Social Security, 17(2), 202-226.

Mottweiler, H., Heinrich, S., Shire, K., Wacker, M., \& Wang, Ch-Ch. (2014). Patterns of crossborder temporary agency work in interregional comparison: The EU and East Asia. Working Brief 1 Projekt: Cross-Border Temporary Staffing, Universität Duisburg-Essen.

OECD. (2011). International migration outlook: SOPEMI 2011. Paris: OECD Publishing.

OECD. (2012). International migration outlook: SOPEMI 2012. Paris: OECD Publishing.

Olsson, L. (1996). Labor migration as a prelude to world war I. International Migration Review, 30(4), 875-900. doi:10.2307/2547596.

Peixoto, J., Arango, J., Bonifazi, C., Finotelli, C., Sabino, C., \& Strozza, S. (2012). Immigrants, markets and policies in Southern Europe. The making of an immigration model? In M. Okólski (Ed.), European immigrations: Trends, structures and policy implications (pp. 107-147). Amsterdam: Amsterdam University Press.

Petersen, R. (2006). Be our guest, but please don't stay: A comparison of U.S. and German immigration policies and guest worker programs. Tulsa Journal of Comparative and International Law, 14(1), 87-118.

Skills Panorama, E. U. (2014). Focus on foreign languages (analytical highlight). Brussels: European Commission.

Venturini, A. (2004). Postwar migration in Southern Europe, 1950-2000. An economic analysis. Cambridge: Cambridge University Press.

Zimmermann, K. F. (1996). European migration: Push and pull. International Regional Science Review, 19(1-2), 95-128. doi:10.1177/016001769601900211.

Open Access This chapter is licensed under the terms of the Creative Commons AttributionNonCommercial 2.5 License (http://creativecommons.org/licenses/by-nc/2.5/), which permits any noncommercial use, sharing, adaptation, distribution and reproduction in any medium or format, as long as you give appropriate credit to the original author(s) and the source, provide a link to the Creative Commons license and indicate if changes were made.

The images or other third party material in this chapter are included in the chapter's Creative Commons license, unless indicated otherwise in a credit line to the material. If material is not included in the chapter's Creative Commons license and your intended use is not permitted by statutory regulation or exceeds the permitted use, you will need to obtain permission directly from the copyright holder.

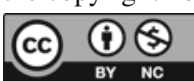




\title{
Chapter 12 \\ Lessons from the South-North Migration of EU Citizens in Times of Crisis
}

\author{
Jean-Michel Lafleur and Mikolaj Stanek
}

\subsection{Five Lessons from the South-North Migration of EU Citizens in Times of Crisis}

In this volume, we have demonstrated that - since its inception in 2008 - the global financial and economic crisis has strongly impacted migration flows to/from/within the European Union as well as the way policy-makers and the public have reacted to them. While we have noted an intensification of South-North migration flows in all the case studies, the political reaction of Northern European receiving countries to this increased mobility has often seemed unrelated to the actual size of the phenomenon. Similarly, Southern European countries of origin have also adopted diverse responses, ranging from indifference to active engagement towards the rising level of departure of their citizens.

Over the past few years, the issue of the mobility of EU citizens has become increasingly salient and controversial. As demonstrated in this volume, the arrival of Southern Europeans has often failed to trigger the same level of animosity in destination countries as that of post-accession migrants from Central and Eastern Europe. Moreover, the renewed influx of asylum seekers to the EU, which intensified exponentially in the summer of 2015, has been seen to precipitate similar high levels of hostility. South-North flows of EU citizens, however, pose a series of questions for the future of migration in the EU: are we witnessing a repetition of the massive South-North migrations that took place two generations ago? Is migration a principal strategy to cope with the effects of crises within the European Union? How is

\footnotetext{
J.-M. Lafleur $(\square)$

FRS-FRNS, Centre for Ethnic and Migration Studies (CEDEM),

University of Liège, Liège, Belgium

e-mail: jm.lafleur@ulg.ac.be

M. Stanek

Department of Sociology and Communication, University of Salamanca, Salamanca, Spain

e-mail:mstanek@usal.es
} 
increasing EU migration shaping the debates and policies in countries of origin and destination?

As we bring this volume to a close, we believe that many elements can be found in the previous chapters to help provide some answers to these questions. Building on our different case studies, we can thus identify five main lessons from the renewed migration flows of Southern European EU citizens that are key to our understanding of contemporary migration dynamics within the EU. While the method that has guided our efforts is not strictly comparative, the comparison of elements drawn from carefully selected case studies ensures the validity of those conclusions. Similarly, the use of different data sources in the country chapters is not an impediment to drawing general conclusions on the characteristics of these new migrants. On the contrary, we believe that this diversity of sources has enabled us to identify the most salient issues with regard to new Southern European migration.

\subsubsection{Lesson 1: New Southern EU Migrants Are Different from Their Predecessors}

The migratory routes that are now leading Southern European migrants to North Western European Member States may be similar to those used by guest workers in the twentieth century, but the conditions of arrival and the socio-economic characteristics of these new migrants are profoundly different. Post-war migration can be seen to have largely occurred in response to recruitment programmes promoted by destination countries. In recent times, by contrast, destination countries-except Germany - have not explicitly extended an invitation to new migrants, as their own economies have also suffered from the effects of the crisis. Whereas Southern European guest workers left countries that were barely or partially industrialized during most of the twentieth century, the new migrants are leaving their home countries after several decades of economic growth as EU-15 Member States. Unsurprisingly, the different socio-economic contexts in which old and new Southern European migration occurred are widely reflected in the socio-demographic profiles of citizens leaving during the crisis. As has been shown in Chap. 11, the current migrants from Southern Europe are on average better educated compared to their post-war predecessors. This is partly related to a general improvement in educational attainment in these societies as well as to the vulnerable situation of young adults in the labour market, who use migration as a coping strategy in times of crisis. However, even though the economic crisis has hit most severely segments of the population with low levels of human capital, highly skilled individuals are overrepresented in the new flows of Southern European migrants because they are the ones who are able to better respond to the labour market needs of Northern EU Member States. In other words, although it is still unclear how well these new migrants are performing in the labour markets, the selectivity of flows according to 
skills level shows that the transforming structure of demand for labour force in postcrisis Northern EU economies may play a crucial role in shaping current SouthNorth flows.

Another important factor that determines the profile of current Southern European migrants is the decreasing role of networks in migration strategies. This feature contrasts clearly with previous waves of South-North migration, when the flows were managed on a collective basis within a framework of bilateral agreements. Current flows are now more individualized but also more dependent on migrants' skills characteristics and their capacity to adjust to the specific needs of Northern EU labour markets.

These trends should not hide the fact that, as shown in the country chapters, current South-North migration is far from being homogenous. While statistics on this matter are hard to collect, the different country chapters hint at the fact that a share of the new Southern European migration has had a previous migration experience. Indeed, some new Southern EU migrants are third country migrants who obtained citizenship in Southern Europe and either returned to their home country or moved North with the economic crisis.

Lastly, transformations between pre and post crisis in migration patterns are not uniformly visible in the case of Southern European countries. The case of Portugal differs significantly from others due to the larger volume of migration flow compared to its overall population. In addition, migration from Portugal seems to be less selective with regard to skills level. Unlike other Southern EU Member States, migration from Portugal has never ceased. Although the scarcity of data does not allow us to draw categorical conclusions, this fact may explain why the new flows of Portuguese emigrants are not so different from the previous ones.

\subsubsection{Lesson 2: Migration Is a Strategy Adopted by Citizens and States in Response to Crises}

As we have clearly shown in this volume, the level of mobility of citizens within the EU has significantly increased during the crisis but, overall, only a very small minority of EU citizens actually reside in a Member State other than their state of nationality, even after the crisis. Considering the harshness of the recession in most EU Member States, this data could be viewed as surprising. The case study of Greece, for instance, showed that the crisis triggered an increase in migration flows but that-in spite of a strong increase in unemployment-flows have remained somewhat limited in absolute terms.

Even though migration is a strategy adopted by some in response to the crisis, not all sectors of the population in Southern Europe have equal opportunities to emigrate. In this volume, we have placed particular emphasis on the process of labour market segmentation, which, even before the crisis, had been creating a strong disparity between different groups of workers in terms of protection. Italy and Greece 
best exemplify this situation. Older workers there tend to hold long-term and stable contracts, while young cohorts of workers occupy mostly insecure, highly-flexible and low-paid jobs. This segmentation of the labour market in Southern Europe has been reinforced with the crisis since contracting and dismissal on the basis of fixedterm contracts have become more common.

Throughout this volume, we have thus demonstrated that migration is a strategy used by only some EU citizens to deal with the effects of the crisis. Others either do not need to take this approach, or make use of alternative strategies that do not entail physical mobility. Such strategies have been identified in the various case studies featured and they include housing strategies by which young adults return to live in the parental home or educational strategies consisting of delaying or suspending entry into the job market by resuming tertiary education. Reasons for choosing alternatives to migration include the fact that - in Southern Europe as in other parts of the world-migration is simply not an option that is available to all citizens who find themselves in a situation of vulnerability.

As shown in the case studies here, debates on the skills levels of new Southern EU migrants have strongly influenced the reaction of both sending and receiving countries to crisis migration. With regard to receiving countries, the case of Germany showed that limited skills, issues with the recognition of skills and a low level of language proficiency may still discourage would-be emigrants from leaving and may hinder the successful socio-economic integration of those who do emigrate. Yet, Germany's reaction also showed that encouraging immigration is a strategy followed by states in order to cope with the macro-economic and political effects of the crisis. Unlike France, Belgium and the United Kingdom, the German authorities clearly saw an opportunity within the crisis to attract highly-skilled workers, who are greatly needed in order to maintain the country's competitiveness. To this end, Germany has recruited workers from Southern Europe and provided them with training in order to facilitate their integration into the labour market. This strategy is, however, only a very partial response to Germany's labour force needs.

Sending countries, by contrast, have been less eager to promote emigration as a solution to unemployment. Unlike other periods in history when Southern European governments explicitly encouraged migration as a safety valve, they are now very reluctant to even acknowledge the existence of crisis-related migration. The Spanish government's insistence on describing new emigrants as "youngsters in search of adventure" is particularly telling in this respect. This attitude illustrates the dilemma in which Southern European governments find themselves with regard to crisisrelated migration. On the one hand, these flows may marginally reduce the pressure on social assistance systems and improve unemployment statistics. On the other hand, explicitly encouraging emigration could be interpreted as a failure by the government to provide an adequate response to the crisis. As shown very clearly in the case of Greece, Portugal and Spain, debates on crisis-related emigration have often been used by political parties to open up larger debates on austerity and the management of the crisis. In other words, emigration data has been instrumental- 
ized by political parties in sending countries to discuss the adequacy of macroeconomic policy responses in times of crisis.

\subsubsection{Lesson 3: The Principle of Freedom of Circulation Does Not Apply Equally to All EU Citizens}

Freedom of circulation is one of the achievements of the European integration process that is most appreciated by EU citizens, in spite of variations in the levels of support for this policy across Member States. This right has never been absolute and safeguards have always existed to limit the freedom of circulation of undesirable EU migrants (e.g. criminals, the unemployed, etc.). With the crisis, Northern European Member States have made increasing use of those safeguards and have even called for further restrictions upon the freedom of circulation. Those states do not, however, uniformly target all EU citizens. Instead, a process of segmentation in access to freedom of circulation - which started before the crisis - has been progressively reinforced with the economic crisis. This segmentation process operates along three lines.

First, with regard to occupation, it is important to note that the mobility rights of pensioners and students have not at all been questioned in recent years. Also, within the category of EU workers, only highly-skilled workers have continued to remain desirable in the eyes of governments. As shown with the case of Italian associations in Brussels (see Chap. 7), highly-skilled migrants are also those who have access to the most resources to mobilize and react when their freedom of circulation is being contested. By contrast, posted workers, low-skilled EU workers and mobile unemployed EU citizens have been at the centre of many controversies in Northern European Member States. As we have shown in several chapters, these categories of migrants have been increasingly depicted as illegitimate EU movers, whose rights to circulation should be strongly limited. The most telling example of this discrepancy in the definition of legitimate EU mobility can be seen in the United Kingdom. In this country, discourses and policies are becoming increasingly hostile towards new EU migrants coming to work in the UK, while the right of retired British citizens to reside in France and in Southern Europe (and to access social services like health care in those countries) is not being contested.

Second, Nationality is the second line along which segmentation operates in EU citizens' use of freedom of circulation. Even after the lifting of the temporary restrictions on freedom of circulation, the mobility of Central and Eastern European EU citizens has usually been more contentious than that of Southern Europeans. The sizeable difference in flows provides an explanation for this different perception. Most importantly however, populist and xenophobic political parties of several Member States have used the cliché of the "invasion of Central and Eastern European migrants" for over a decade in order to justify their anti-migration stance. The "Polish plumber" in France, the "Polish butcher" in Germany or the "Romanian 
construction worker" in Belgium are the best examples of this rhetorical effort to associate perceived negative effects of EU migration with specific nationalities of EU citizens.

Southern EU citizens have been affected by restrictive policies applied to all EU citizens in times of crisis. These policies undermine their ability to make use of their freedom of circulation in Northern Europe. But, in the cases we reviewed, only in the United Kingdom did we find explicit negative references made by policy-makers towards new Southern Europeans. Underlying this, and this is the third line of segmentation, is the fact that the history of migration has benefited Southern European migrants more than those from Central and Eastern European when they moved in times of economic crisis. Long-established Southern European migrant communities did not necessarily generate a higher level of intra-community solidarity between old and new migrants. Yet, new Southern European migrant communities, such as the Italians in Belgium or the Portuguese in France, have often had a comparative advantage when dealing with attacks on their freedom of circulation: they are able to benefit from long-established homeland institutions and organizations (i.e. political parties, trade unions, immigrant associations, etc.) based in receiving countries. Such organizations specialize in defending immigrant rights and have built significant connections over the years with other institutions and organizations based in destination countries. The mobilization of civil society organizations against the removal of residence permits from Southern Europeans living in Belgium, who are much less affected by this policy than Central Eastern European migrants, is a very telling example of this discrepancy.

\subsubsection{Lesson 4: Welfare Is an Instrument for Controlling and Delegitimizing EU Migration}

Another key lesson of this volume is that social policy, and welfare in particular, are increasingly being used by Member States to limit the arrival of the afore-mentioned category of "illegitimate EU migrants". The British and Belgian case studies underlined the fear held by Member States of seeing EU migrants abuse their welfare systems. In both cases, those fears have led to important policy decisions, whose consequences have been to restrict access to welfare for mobile EU citizens. The context of crisis, and its associated discourse regarding the need for austerity measures to bring public expenditure under control, has greatly helped the implementation of those measures. The crisis has enabled policy-makers to frame a discourse on the inability of Member States to respond to the social protection needs of all foreigners, and of EU citizens in particular. Restricting the access of mobile EU citizens to social protection does not serve exclusively to reduce welfare spendings. In practice, it delegitimizes EU migrants by creating a consistent link between EU 
migration and "benefit tourism" in spite of the evidence demonstrating that this practice is marginal.

In addition to decreasing social protection, we have seen that social policy has also become an alternative form of migration policy. As the EU treaties and legislation leave Member States with little power to limit the freedom of circulation of citizens, controlling EU migrants' access to welfare has become a new way for states to filter undesirable migrants. During the 2015 general election campaign and the "Brexit" campaign in the United Kingdom, the centrality of the debate on EU citizens' access to welfare was very telling of this move towards a management of EU migration through welfare. Also, in recent years, Member States have similarly paid growing attention to Directive 2004/38/EC on the right to free movement of EU citizens, which allows states to remove the residence permits of EU citizens who represent an "unreasonable burden on the social system" of their country of residence. The Belgium case study showed how radical the change of policy has been in this matter following the financial and economic crisis. Having moved on from expelling only a handful of citizens on the basis of the directive in 2007, Belgium has subsequently been expelling around 2,500 EU citizens every year since 2012. Interestingly, Belgium's policy sends a clear signal to newcomers and would-be EU immigrants to the country: using social protection may serve as a basis for removing their residence permit if those migrants are believed to cost more than they contribute to the Belgian social protection system. While future rulings of the European Court of Justice may revoke or set limits on the Belgian policy, this example shows how far the implementation of social policies may act as a filter to keep undesirable EU migrants out.

\subsubsection{Lesson 5: We Need to Talk About Brain Gain and Brain Drain Within the EU!}

In Europe, migration and development scholars have traditionally been concerned with issues of brain drain, but studies have focused mostly on the impact of the phenomenon on non-European sending states fearful of losing their highly-educated citizens to the benefit of the EU labour market. In the four Southern European countries studied in this volume, we have, however, noted that policy-makers have expressed concerns about a possible South-North internal brain drain being triggered or intensified by the crisis. As shown in this volume, there is some evidence of strong participation of highly-skilled workers among the new emigrants, but given the limited volume of the outflow, it is still too early to talk about human capital flight or brain drain.

The fear of losing the best-educated citizens seems to be largely shared in Southern Europe, with the possible exception of Spain, where the very idea of crisis-related migration has long been repudiated by the Conservative government, whilst at the same time being emphasized by opposition parties. Among the expected negative outcomes of the current waves of emigration, there is the risk that Southern 
European countries will find themselves with a lack of a skilled workforce when the economic situation improves. This obviously opens up space for debates about the legitimacy of high-skilled worker recruitment programmes within the EU, such as Germany's "Job of my Life". Indeed, even though this programme may offer relief to a very limited number of Southern European unemployed citizens (and their governments), questions remain regarding the long-term macro-economic effects of this loss of work force, whose training was paid for by the sending country's taxpayers.

Beyond espousing discourses, the Portuguese, Spanish and Greek governments have done very little to tackle the issue of brain drain. Only the Italian authorities seem to have tried hard to address the issue with specific policy measures such as tax incentives, pension benefits, access to social housing and seed money programmes for highly-skilled returnees. In the three other cases, no real policy response has been offered to what is described by many within the national political arena as an issue of critical importance. Italy's approach can be explained by a long tradition of engagement with its citizens abroad, which has seen the development of a very thorough system of representations of emigrants' interests in the home country. Such a system, associated with a strong representation abroad of Italian institutions and associations (i.e. political parties and trade unions) has kept the issue of emigration and brain drain on the political agenda for over a decade. By contrast, Greece has historically had a more ambivalent attitude towards its citizens living abroad and has engaged with them to a much lesser extent. It is particularly noteworthy, for instance, that Greek migrants remain one of the few groups of EU citizens who are deprived of external voting rights in their home country elections (Lafleur 2013). Engaging with citizens abroad should, however, be of crucial importance for sending state authorities in the current socio-economic environment for at least two reasons. First and foremost, growing xenophobia and limits on access to social protection in destination countries is placing a growing number of their emigrants in a position of vulnerability. Accordingly, not only do new Southern EU migrants sometimes need assistance, but they also need their home country governments to enter into a dialogue with Northern European governments when their rights are being jeopardized while living abroad. Second, if Southern European Member States are serious about involving return migrants in economic recovery efforts, a dialogue needs to be opened rapidly with crisis-related emigrants regarding the policies that would facilitate their return to their home country.

\subsection{Conclusion: Moving Research and Political Agendas Forward}

This collaborative book is one of the first attempts to assess comprehensively and systematically the main features of crisis-driven South-North EU migration. Even though we have explored the impact of this phenomenon on public debates and 
political agendas in selected sending and receiving countries, several questions still require further research efforts and in-depth reflection.

This volume has shown clearly that more systematic and rigorous statistical data is needed in order to obtain a more complete and detailed picture of the current migratory phenomenon in Europe. Similarly, this book has demonstrated the added-value of conducting focused research with international research teams based both in immigrants' countries of origin and destination.

This book opens the way for explorations of several issues that have not as yet been addressed. One of the most important issues is probably the long-term insertion of new Southern European migrants into Northern EU Member States and its connections with the large-scale East-West post-accession migration. Throughout the book, it has been hypothesized that the patterns of labour market insertion of migrants from the new accession countries is one of the factors that explains the increasing selectivity in the new flows of South-North migration. However, more research is needed to understand the reciprocal influence of these on the type of contemporary EU migrations (Kaczmarczyk and Stanek 2015). Examining these interactions would not only shed new light on the complex map of current intra-EU mobility, it would also help us understand the causal mechanisms that lie behind these newer patterns of migration.

In this volume, we have also argued that the full re-establishment of the old South-North migratory route depends on a hypothetical continuing divergence in economic performance between Northern and Southern EU Member States. If the crisis remains strong in the South but eases in the North, rising demand for labour may increase Southern European flows. However, the current economic performance in the Northern EU Member States under study here revealed that the demand for labour is at present insufficient to trigger a complete revival of the post-war South-North migratory route.

Future trends of internal mobility within the EU will depend not only on future economic performances but also on the evolution of the anti-migration sentiment in Northern European societies. As described in this volume, restrictions on migration from other EU28 countries are either currently under discussion or have already been implemented in several Northern EU Member States. As the growing animosity towards new migrants is being publicized in the Southern European media, potential new migrants may be discouraged from making use of their right to circulation. In addition, the large influx of asylum seekers since the Spring of 2015 and the "Brexit" referendum further demonstrated that immigration is likely to remain a topic of contention in the EU in the coming years, even if the economic situation improves. The impact of the asylum crisis and of the "Brexit" vote on the freedom of circulation of EU citizens is hard to determine at this stage. However, this situation indicates that the European Union will be facing the difficult task of reflecting simultaneously on its asylum policy and its internal mobility policy in the coming years. 


\section{References}

Kaczmarczyk, P., \& Stanek, M. (2015). Crisis and beyond: Intra-EU mobility of Polish and Spanish migrants in a comparative perspective. In A. Triandafyllidou \& I. Isaakyan (Eds.), High skill migration and recession: Gendered perspectives (pp. 69-100). Houndmills: Palgrave Macmillan.

Lafleur, J. M. (2013). Transnational politics and the state. The external voting right of diasporas. New York: Routledge.

Open Access This chapter is licensed under the terms of the Creative Commons AttributionNonCommercial 2.5 License (http://creativecommons.org/licenses/by-nc/2.5/), which permits any noncommercial use, sharing, adaptation, distribution and reproduction in any medium or format, as long as you give appropriate credit to the original author(s) and the source, provide a link to the Creative Commons license and indicate if changes were made.

The images or other third party material in this chapter are included in the chapter's Creative Commons license, unless indicated otherwise in a credit line to the material. If material is not included in the chapter's Creative Commons license and your intended use is not permitted by statutory regulation or exceeds the permitted use, you will need to obtain permission directly from the copyright holder.

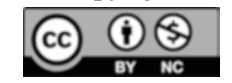

